
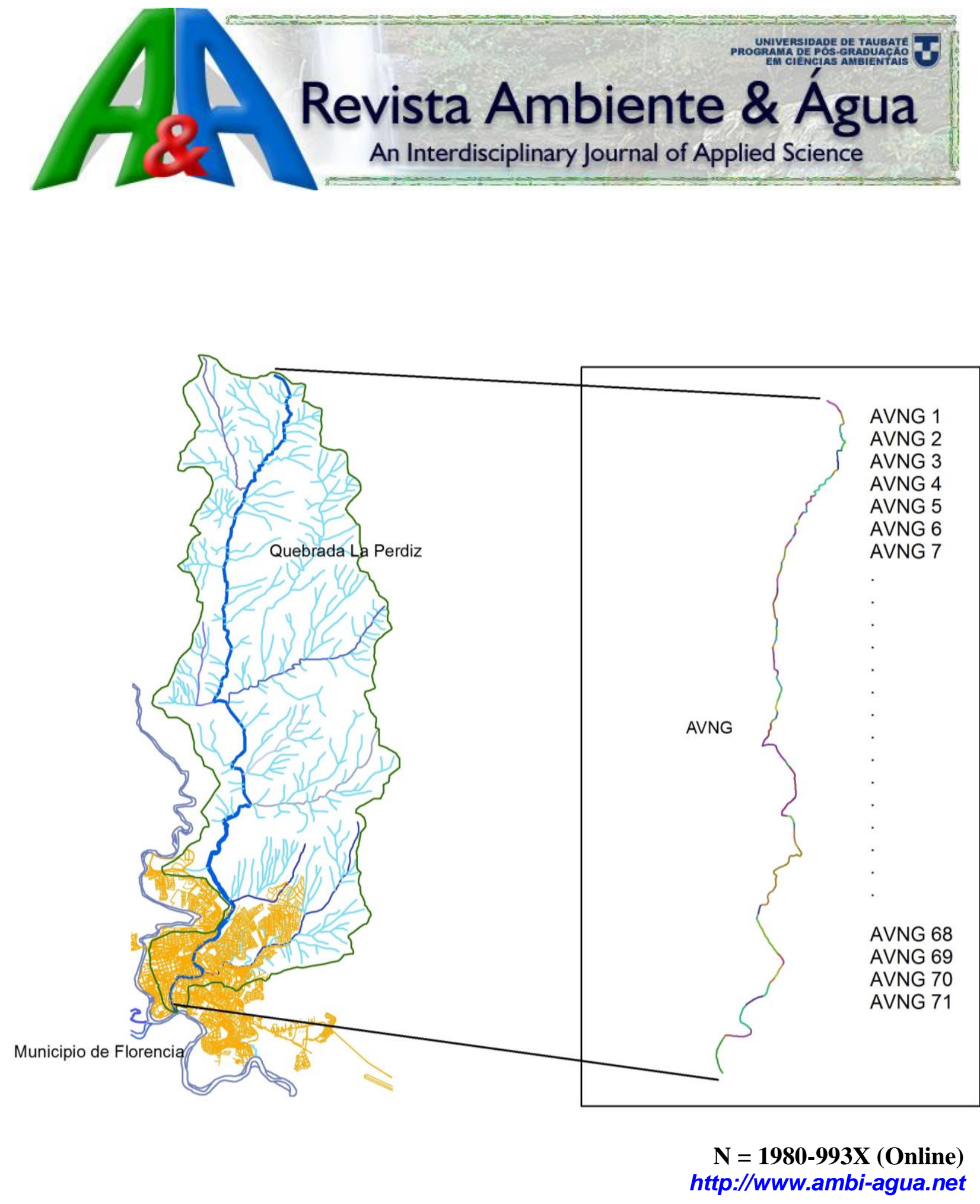

$36^{\text {th }}$ Edition of Revista Ambiente \& Água - An Interdisciplinary Journal of Applied Science, Taubaté, V. 12, N.1, p. 1-167 Jan./Feb. 2017. (doi:10.4136/ambi-agua.v12.n1) 


\section{EDITORIAL BOARD}

\section{Editor}

Getulio Teixeira Batista

Instituto de Pesquisas Ambientais em Bacias Hidrográficas (IPABHi), SP, BR

Amaury Paulo de Souza

Ana Aparecida da Silva Almeida

Andrea Giuseppe Capodaglio

Antonio Evaldo Klar

Antonio Teixeira de Matos

Apostol Tiberiu

Carlos Eduardo de M. Bicudo

Cláudia S. de C. M. dos S. Cordovil

Dar Roberts

Delly Oliveira Filho

Ehsan Noroozinejad Farsangi

Gabriel Constantino Blain

Giordano Urbini

Gustaf Olsson

Hélio Nobile Diniz

Ignacio Morell Evangelista,

János Fehér

João Vianei Soares

José Carlos Mierzwa

Julio Cesar Pascale Palhares

Luis Antonio Merino

Marcelo dos Santos Targa

Maria Cristina Collivignarelli,

Massimo Raboni

Nelson Wellausen Dias

Petr Hlavínek

Richarde Marques da Silva

Silvio Jorge Coelho Simões

Stefan Stanko

Teresa Maria Reyna

Yosio Edemir Shimabukuro

Zhongliang Liu Beijing

Editorial Section

Text Editors

Reference Editor

Layout Editors

Technical Support

Secretaria e Comunicação

\section{Associate Editors}

Universidade Federal de Viçosa (UFV), BR

Universidade de Taubaté (UNITAU), BR

University of Pavia, ITALY

Universidade Est. Paulista Júlio de Mesquita Filho (UNESP), BR

Universidade Federal de Viçosa (UFV), BR

University Politechnica of Bucharest, Romania

Instituto de Botânica, IBT, BR

Centro de estudos de Engenharia Rural (CEER), Lisboa, Portugal

University of California, Santa Barbara, United States

Universidade Federal de Viçosa (UFV), BR

International Institute of Earthquake Engineering and Seismology(IIEES), Farmanieh, Tehran, Iran

Instituto Agronômico de Campinas, IAC, Brasil.

University of Insubria, Varese, Italy

Lund University, Lund, Sweden

Inst. Geológico, Sec. do Meio Amb. do Est. de SP (IG/SMA),BR

University Jaume I- Pesticides and Water Research Institute, Spain

Debrecen University, Hungary

Instituto Nacional de Pesquisas Espaciais (INPE), BR

Universidade de São Paulo, USP, BR

Embrapa Pecuária Sudeste, CPPSE, São Carlos, SP, BR

Institute of Regional Medicine, National University of the Northeast, Corrientes, Argentina

Universidade de Taubaté, (UNITAU), BR

University of Pavia, Depart. of Civil Engineering and Architecture, Italy

LIUC - University "Cattaneo", School of Industrial Engineering, Italy

Inst. Bras. de Geogr. e Estatística (IBGE). Aracaju, SE, BR

Brno University of Technology República Tcheca

Universidade Federal da Paraíba, UFPB, BR

Univ. Est. Paulista Júlio de Mesquita Filho, UNESP, BR

Slovak Technical University in Bratislava Slovak, Eslováquia

Universidad Nacional de Córdoba, Argentina

Instituto Nacional de Pesquisas Espaciais (INPE), BR

University of Technology, China

Nelson Wellausen Dias, PPGCA, UNITAU, IBGE, BR

Theodore D`Alessio, FL, USA, Maria Cristina Bean, FL, USA

Getulio T. Batista, UNITAU, BR

Luciana Pedrosa da Fonseca Batista, - New Jersey, USA

Liliane Castro, Bibliotecária - CRB/8-6748, Taubaté, BR

Vera L. F. Batista, IPABHi \& Getulio T. Batista, UNITAU, BR

Tiago dos Santos Agostinho, LAGEO, UNITAU, BR

Luciana Gomes de Oliveira, UNITAU, BR

Library catalog entry by Liliane Castro CRB/8-6748

Revista Ambiente \& Água - An Interdisciplinary Journal of Applied Science / Instituto de Pesquisas

Ambientais em Bacias Hidrográficas. Taubaté. v. 12, n. 1(2006) - Taubaté: IPABHi, 2017.

Quadrimestral (2006 - 2013), Trimestral (2014 - 2016), Bimestral a partir de janeiro de 2017.

Resumo em português e inglês.

ISSN 1980-993X

1. Ciências ambientais. 2. Recursos hídricos. I. Instituto de Pesquisas Ambientais em Bacias Hidrográficas. 


\section{TABLE OF CONTENTS}

\section{COVER:}

Test site to for the geo-inspired model of natural vector multi-agents corresponding to La Perdiz River Basin, Florencia city, Colombia.

Source: MILLAN ROJAS, E. E. et al. Natural vector multi-agents geo-inspired in environmental management. Rev. Ambient. Água, Taubaté, vol. 12 n. 1, p. 47-56, 2017. doi: 10.4136/ambi-agua.1912

\begin{tabular}{|c|c|c|}
\hline 01 & $\begin{array}{l}\text { Water safety: one of the primary objectives of our time } \\
\text { doi: } 10.4136 / \text { ambi-agua. } 1994 \\
\text { Carlo Collivignarelli }\end{array}$ & $1-7$ \\
\hline 02 & $\begin{array}{l}\text { Sodium chloride as a reference substance for the three growth endpoints used in the Lemna minor } \\
\text { L. (1753) test } \\
\text { doi: 10.4136/ambi-agua.1986 } \\
\text { Aline Andrade Godoy; Luciano Bastos de Carvalho; Fábio Kummrow; Paulo Augusto Zaitune Pamplin }\end{array}$ & 8-16 \\
\hline 03 & $\begin{array}{l}\text { Sediments of watersheds from Frutal and Bebedouro Streams (Frutal, MG, Brazil) as an indicator } \\
\text { of human activities } \\
\text { doi: } 10.4136 / \text { ambi-agua. } 1978 \\
\text { Sofia Luiza Brito; Thiago Torres Costa Pereira; Inez Cristina Martins }\end{array}$ & $17-32$ \\
\hline 04 & $\begin{array}{l}\text { Water management assessment methodology for urban planning } \\
\text { doi: 10.4136/ambi-agua.1917 } \\
\text { Giovana Ulian; Ivan Cartes; Maria Manuela C. Lemos Lima }\end{array}$ & $33-46$ \\
\hline 05 & $\begin{array}{l}\text { Natural vector multi-agents geo-inspired in environmental management } \\
\text { doi: } 10.4136 / \text { ambi-agua.1912 } \\
\text { Edwin Eduardo Millán Rojas; José Nelson Pérez Castillo }\end{array}$ & $47-56$ \\
\hline
\end{tabular}

\section{Incertezas e erros na estimativa de vazões usando modelagem hidrológica e precipitação por}

06 doi: 10.4136/ambi-agua.1924

Samuellson Lopes Cabral; Jojhy Sakuragi; Cleiton da Silva Silveira

\section{Crescimento foliar e atividades das enzimas antioxidativas em plântulas de girassol suplementadas com percolado de aterro sanitário e submetidas a estresse hídrico}

07 doi: 10.4136/ambi-agua.1964

Francisco Holanda Nunes Junior; Franklin Aragão Gondim; Valdineia Soares Freitas; Brennda Bezerra Braga; Paulo Ovídio Batista de Brito; Kaio Martins

Análise de metodologias de quantificação de substâncias húmicas em lixiviados de aterros de resíduos sólidos

08 doi: 10.4136/ambi-agua.1972

Letícia Sobral Maia S. Lima; Ronei de Almeida; Bianca Ramalho Quintaes; Daniele Maia Bila; Juacyara Carbonelli Campos

Vegetação arbustivo-arbórea em uma restinga de Jaguaruna, litoral sul do Estado de Santa Catarina, Brasil

09

Robson dos Santos; Guilherme Alves Elias; Aline Votri Guislon; Iara Zaccaron Zanoni 
Composto de lodo de esgoto para o cultivo inicial de eucalipto

10 doi: 10.4136/ambi-agua.1965

Daniela Cristina de Souza Afáz; Kaique Bizon Bertolazi; Ricardo Augusto Gorne Viani; Claudinei Fonseca Souza

Aspectos socioambientais e qualidade da água de dessalinizadores nas comunidades rurais de

11 Pentecoste-CE

11 doi: 10.4136/ambi-agua.1722

Antônia Leila Rocha Neves; Mailson Pereira Alves; Claudivan Feitosa de Lacerda; Hans Raj Gheyi

Comparação entre metodologias de amostragem de água para quantificação de variáveis limnológicas em ambiente lótico

12 doi: 10.4136/ambi-agua.1781

Mayanna Silva Bessa Leite; Flávia Mariani Barros; Danilo Paulúcio da Silva; Romário Oliveira de Santana; Jhones da Silva Amorim; Stênio Rocha de Carvalho

\section{Caracterização hidroambiental de nascentes}

13 doi: 10.4136/ambi-agua.1909

Mariana Santos Leal; Kelly Cristina Tonello; Herly Carlos Teixeira Dias; Rafael Mingoti

Monitoramento da água de poços como estratégia de avaliação sanitária em Comunidade Rural na Cidade de São Luís, MA, Brasil

14 doi: 10.4136/ambi-agua.1962

Silvio Carlos Coelho; Antonio Nascimento Duarte; Ludimila Santos Amaral; Paulo Medeiros dos Santos; Maria José Salles; José Augusto Albuquerque dos Santos; Adriana Sotero-Martins 


Ambiente \& Água - An Interdisciplinary Journal of Applied Science
ISSN 1980-993X - doi:10.4136/1980-993X
www.ambi-agua.net
E-mail: ambi.agua@gmail.com

\title{
Water safety: one of the primary objectives of our time
}

\author{
doi:10.4136/ambi-agua.1994
}

Received: 31 Aug. 2016; Accepted: 04 Oct. 2016

\section{Carlo Collivignarelli}

\author{
Member of the Editorial Committee of Ambiente \& Agua Journal \\ University of Brescia, Brescia, Italy \\ Department of Civil Engineering, Architecture, Territory, Environment and Mathematics \\ e-mail: carlo.collivignarelli@unibs.it
}

\begin{abstract}
This article discusses the benefits of an innovative approach to the problem of water security introduced by WHO in 2004, through the establishment of the Water Safety Plan (WSP). It was recently included in Commission Directive (EU) 2015/1787 - October 6, 2015 - the implementation of which is expected in the EU countries by 27 October 2017. The WSP is the most effective means of consistently ensuring the safety of a drinking water supply. The method is based on the use of a comprehensive risk assessment and risk management approach that involves all steps in water supply from catchment to consumer. The knowledge acquired by some experiences of WSP application, both in Italy and in countries with limited resources, is proving the effectiveness of the model as the best way to manage drinking water systems and protect public health.
\end{abstract}

Keywords: drinking water, risk management, water safety plan.

\section{Segurança da água: um dos objetivos primários do nosso tempo}

\section{RESUMO}

Este artigo discute os benefícios de uma abordagem inovadora para o problema da segurança da água introduzido pela OMS em 2004, por meio do estabelecimento do Plano de Segurança da Água (acrônimo em Inglês WSP). Foi recentemente incluído na Directiva da Comissão (UE) 2015/1787 - 6 de outubro de 2015 - cuja implementação está prevista nos países da UE até 27 de outubro de 2017. O WSP é o meio mais eficaz para garantir consistentemente a segurança de um abastecimento de água potável. O método baseia-se no uso de uma abordagem de gestão de avaliação e gerenciamento abrangente de risco, que envolve todas as etapas de abastecimento de água desde a captação até o consumidor. $\mathrm{O}$ conhecimento adquirido por algumas experiências de aplicação do WSP, tanto na Itália quanto em países com recursos limitados, está demonstrando a eficácia do modelo como a melhor maneira de gerenciar o sistema de água potável e proteger a saúde pública.

Palavras-chave: água potável, gestão de riscos, plano de segurança da água.

\section{DISCUSSION}

The availability of water in sufficient quantity and with a quality able to ensure health is one of the most important problems facing mankind today. 
The importance of this was previously recognized among the goals of the millennium, and in goal 6 of the United Nations' plan for sustainable development (Clean water and sanitation): "Ensure availability and sustainable management of water and sanitation for all". In goal 6, it is of note that the basic requirements for "drinking water" are: "quantity" (volume of water available to consumers), "quality" (conformity to potability requirements), "continuity" (water supply over time), "coverage" (population served by drinking water supply) and "cost" (costs incurred by consumers for drinking water supply).

A large portion of the world's population today has no access to water that fully meets the goal's requirements, or that meets them in a sustainable way. Just think about it, according to WHO/UNICEF data, in 2015 almost seven hundred million people had no access even to an "improved water source" (according to WHO and UNICEF (2010), a "water source that, by nature of its construction or through active intervention, is protected from outside contamination, in particular from contamination with fecal matter"). Moreover, if one considers that the so-called "improved sources" can distribute no safe water (both from chemical and microbiological points of view) (Sorlini et al., 2013a), and that the distribution of "safe water at the source" does not guarantee the quality at the point of use (Sorlini et al., 2013b), as contamination may occur along the supply chain (transport and storage), then it becomes clear that the population number above is under-estimated, and that the number of people with no safe water is actually much higher.

Faced with this situation, in 2004 WHO introduced an innovative approach to the problem of water security, through the Water Safety Plan (WSP) (WHO, 2004). The characteristic approach of a WSP is based on the assessment and management of risk of water contamination at all stages of the water supply chain, from the point of capture to the point of consumption. The WSP's goal is to eliminate or reduce any chemical, microbiological, physical and radiological danger and to prevent re-contamination during storage and distribution to the point of use.

The WSP redefines the drinking water control mode, which is today based upon monitoring of limited segments of the "waterworks system" (withdrawal - processing distribution), and turning it into a "global system of risk management from collection to the point of use".

The general objectives of a WSP are summarized below:

- describe and analyse the drinking water supply chain;

- identify all the factors that can cause a risk of contamination;

- eliminate or mitigate these factors;

- prevent possible re-contamination.

In more detail, the first experiences of the WSP implementation in Italy (Sorlini et al., 2015a; 2016) have led to a detailed procedure for its application, based on the following steps:

1.formation of a multidisciplinary team;

2. description of the water system;

3.identification of hazardous events, hazards and risks;

4.identification and validation of control measures and re-calculation of the risk;

5. development of an upgrade plan;

6.development of a monitoring plan of the control measures; 
7.development of a plan to test the WSP's effectiveness;

8. development of management procedures;

9. planning and implementation of periodic WSP reviews;

10. revision of the WSP as the result of an accident;

11. development of support programs.

All indicated steps are important and must be developed with skill and care if the WSP is to fully attain its intended purpose. However, the success of the procedure is based upon the "technical phases" related to the system description (step 2) and to the knowledge of its performance and optimization (steps 5, 6, 7, 8, 9). An example of methodological plan for the control and optimization of the performance of a water treatment plant is presented in Figure 1 (from Sorlini et al., 2015a); it was the basis for the operator's implementation of the WSP. In that plan, or in similar plans which were applied in Italy (Crotti et al., 2012), the first part is routine monitoring (Phase 1), the outcomes of which are examined through intensive monitoring (Phase 2), which allows a focus on problems that are then highlighted, also in their quantitative aspects, by means of laboratory and/or field tests (Phase 3). These are the so-called "experimental functionality tests" which, with appropriate frequency, should become an established procedure for the "good management" of water treatment plants. These checks are essential support for the WSP's success and for the basic knowledge to define the operational and structural upgrading interventions that must be made to meet the needs of the particular plant (Phase 4). In this regard, recent literature (Lamrini et al., 2014; Vieira et al., 2008; Chang et al., 2007) offers interesting studies that, using the methodology described in Figure 1, have led to the optimization of different water treatment plants by means of "targeted upgrading" and, at the end of the intervention, have sometimes even resulted in a substantial savings of operating costs (Sorlini et al., 2015b). In addition, this method was successfully applied when it was necessary to adapt to a new, more stringent limit for some specific parameters. For instance, this was the case with arsenic, whose limit for human consumption was recently reduced to $10 \mu \mathrm{g} \mathrm{L}^{-1}$ from its previous limit of $50 \mu \mathrm{g} \mathrm{L}^{-1}$. After application of the functionality tests to the already-operating plants, the new limit for arsenic was achieved, sometimes through targeted structural upgrading in the treatment chain, sometimes with simple plant adaptations to new requirements (for example, by using an existing unit operation for a different process purpose), sometimes even with only the introduction of dosing and control systems without changing the process chain (Sorlini et al., 2014; Sharma et al., 2016). However, the facilities already subject to "monitoring/functionality tests" were the first to implement the new WSP procedure.

Besides ensuring reliability of the water systems (both for drinking water treatment plants and for water distribution system - Bigoni et al., 2014) through the identification of risks and a good knowledge of water treatment processes, the WSP also enables the discovery of problems related to compounds usually not controlled by routine monitoring, such as chemicals of geogenic or anthropogenic origin (uranium, chemicals from industrial and mining contamination, etc.), residues of pharmaceutical, personal hygiene and care products, perfluorinated compounds, and nanomaterials (Lucentini et al., 2016). Among the risk factors are emerging ones also to be considered, such as the monitoring of chemicals compounds not previously analyzed or the monitoring at significantly lower levels of known analytes. These compounds are generally referred to as contaminants of emerging interest, and the risk posed to human health or to the environment as well as their frequency or their origin are not fully known. 


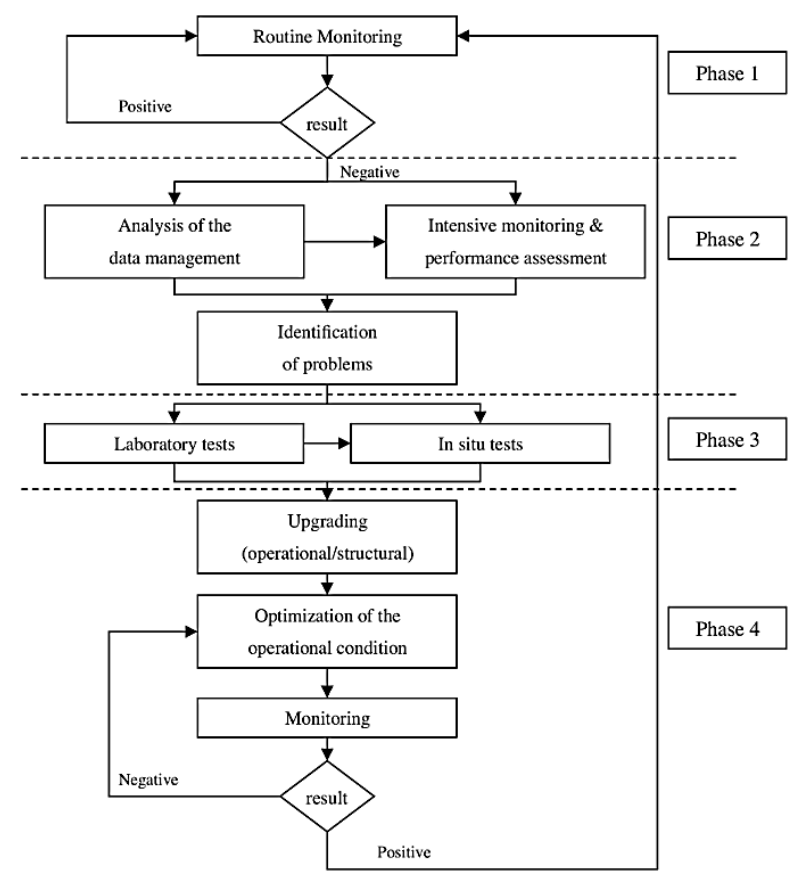

Figure 1. Scheme of the methodological approach proposed in order to assess and optimize Drinking Water Treatment Plants performance (Sorlini et al., 2015a).

An interesting aspect of the WSP is its versatility: it is applicable to all water supply systems, irrespective of their size or complexity; therefore, large- and small-scale urban and rural water supply chains may be included (Lucentini et al., 2016).

In particular, the WSP has proven to be a useful instrument even in countries with limited resources. Interesting results were achieved in Senegal and Burkina Faso (Rondi et al., 2015). In Senegal, the issue was the high contamination of the groundwater by fluorides, but there were also hygienic problems related to treatment, storage and water distribution. The WSP was implemented through the formation of a composite team, formed by the Health Authorities of Diourbel, the network operator and the representatives of the population. All of the WSP steps were then developed, although sometimes in a simplified form, leading to the final sharing of interventions to counter contamination, often by means that were very simple but very effective in the local context (e.g., cleaning of tanks, protection of wells from animal intrusions, etc.).

In the case of Burkina Faso, unprotected wells were contaminated by microbes in the absence of chlorination. A simplified WSP was implemented for each well in the 11 villages included in the intervention. Even though all of the steps of the procedure were not applied, it achieved a positive result, as the WSP has raised the awareness of local communities to minimize contamination hazards, and has also achieved an important improvement in the microbiological quality of water (with removal of 60 to $85 \%$ of $E$. coli contamination at the source, along the transport and at the point of use).

The first "experimental" applications of the WSP are confirming the expected benefits in practice. These cover many aspects, from human health to management, including economic and institutional components. These cases show the method's ability to identify and manage all possible risks of water contamination and at the same time to improve the degree of consumer confidence in water services. These two fundamental objectives are similar in the first applications in Italy and in very different contexts, such as in the rural African situations mentioned above (Rondi et al., 2015). Among the expected results that are being confirmed in 
the described cases, the identification of critical points of the system that would not otherwise have been identified without the WSP, and investments on "critical points" of the system, where the level of risk is higher, are very important.

The first applications of the WSP identified some problems in the procedure: these range from the difficulty of identifying all hazards to the classification criterion of the consequences' severity, to the lack of a "simplified" procedure to be applied to small water supply systems.

However, "concrete" proposals for improvement of the procedure have resulted from these problems. For example:

1. definition of simplified criteria for the application of the WSP for small drinking water supply systems;

2. more active involvement of consumers during the WSP drafting process;

3. establishment of incentives for managers who implement the WSP.

Among the proposals, one is perhaps the most important for emphasizing the role of Sanitary and Environmental Engineering: the spread and systematic implementation of "functionality tests". This approach, based on experiences already available, will give rigorous and effective methodology for:

- performance evaluation of the system in its actual configuration;

- assessing the effectiveness of existing control measures;

- the identification of the "critical problems" of the system in its actual configuration;

- the definition of new preventive and control measures;

- the definition of a monitoring plan to verify the effectiveness of new control measures.

The last aspect that must be emphasized is perhaps the most important and deals with the education and training of all stakeholders: health and environmental authorities, water system operators, consumers, institutions (from supranational ones to small municipalities) etc. In this education and training, the contribution of University with different water-related disciplines is of course important: it can provide not only the research results of innovative technical systems, but also more direct and immediate support of application methods appropriate to different contexts.

On this front, in many countries institutions operate with the aim of utilizing "appropriate technology" (Sorlini et al., 2015c). The new "safe water for all people" challenge, with useful procedures such as the WSP, will be a stimulus to achieve a goal that may also help to "harmonize" discordant policies in a world today so divided.

\section{REFERENCES}

BIGONI, R.; SORLINI, S.; COLLIVIGNARELLI, M.C.; BERBENNI, P. Drinking water quality assessment and corrosion mitigation in the hospital water supply system of Chacas village (Peru). Revista Ambiente \& Água, v. 9, n. 3, p. 379-389, 2014. http://dx.doi.org/10.4136/ambi-agua.1407 
CHANG, E.-E.; CHIANG, P.-C.; HUANG, S.-M.; LIN Y.-L. Development and implementation of performance evaluation system for a water treatment plant: case study of Taipei water treatment plant. Practice Periodical of Hazardous, Toxic, and Radioactive Waste Management, v. 11, n. 1, p. 36-47, 2007. http://dx.doi.org/10. 1061/(ASCE)1090-025X(2007)11:1(36)

CROTTI B. M.; COLLIVIGNARELli, M. C.; SORLINI, S.; CASTAGNOLA F. Performance assessment of real scale drinking water treatment plant. In: INTERNATIONAL SYMPOSIUM ON SANITARY AND ENVIRONMENTAL ENGINEERING, 9., 26-29 June 2012, Milan, Italy. Proceedings... Balmain: TheMHS, 2012.

LAMRINI B.; LAKHAL E. K.; LE LANN M. V. A decision support tool for technical processes optimization in drinking water treatment. Desalination and Water Treatment, v. 52, n. 22-24, p. 4079-4088, 2014. http://dx.doi.org/10.1080/19443994. 2013.803327

LUCENTINI, L.; ACHENE, L.; VESCHETTI, E.; FUSCOLETTI, V.; NIGRO DI GREGORIO, F.; COLAGROSSI, R.; DI BENEDETTO A. Water Safety Plan implementation in Italy. In: INTERNATIONAL SYMPOSIUM ON SANITARY AND ENVIRONMENTAL, 10., 19-23 June 2016, Rome, Italy. Proceedings... Balmain: TheMHS, 2016.

RONDI, L.; SORLINI, S.; COLLIVIGNARELLI, M. C. Sustainability of water safety plans developed in sub-saharan Africa. Sustainability, v. 7, n. 8, p. 11139-11159, 2015. http://dx.doi.org/10.3390/su70811139

SHARMA, A. K.; SORLINI, S.; CROTTI, B. M.; COLLIVIGNARELLI, M. C.; TJELL, J. C.; ABBÀ, A. Enhancing arsenic removal from groundwater at household level with naturally occurring iron. Revista Ambiente \& Água, v. 11, n. 3, p. 486-498, 2016. http://dx.doi.org/10.4136/ambi-agua.1815

SORLINI, S.; PALAZZINI, D.; MBAWALA, A.; NGASSOUM, M. B.; COLLIVIGNARELLI, M. C. Is drinking water from "improved sources" really safe? A case study in the Logone Valley (Chad-Cameroon). Journal of Water and Health, v. 11, n. 4, p. 748-761, 2013a. http://dx.doi.org/10.2166/wh.2013.017

SORLINI S.; PEDRAZZANI R.; PALAZZINI D.; COLLIVIGNARELLI M.C. Drinking Water Quality Change from Catchment to Consumer in the Rural Community of Patar (Senegal). Water Quality, Exposure and Health, v. 5, n. 2, p. 75-83, 2013 b. http://dx.doi.org/10.1007/s12403-013-0089-z

SORLINI, S.; GIALDINI, F.; COLLIVIGNARELLI, M. C. Survey on full-scale drinking water treatment plants for arsenic removal in Italy. Water Practice and Technology, v. 9, n. 1, p. 42-51, 2014. http://dx.doi.org/10.2166/wpt.2014.005

SORLINI, S.; COLLIVIGNARELLI, M. C.; CASTAGNOLA, F.; CROTTI, B. M.; RABONI, M. Methodological approach for the optimization of drinking water treatment plants' operation: a case study. Water Science \& Technology, p. 71, n. 4, p. 597-604, 2015a. http://dx.doi.org/10.2166/wst.2014.503 
SORLINI, S.; BIASIBETTI, M.; COLLIVIGNARELLI, M. C.; CROTTI, B. M. Reducing the chlorine dioxide demand in final disinfection of drinking water treatment plants using activated carbon. Environmental Technology, v. 36, n. 12, p. 1499-1509, 2015b. http://dx.doi.org/10.1080/09593330.2014.994043

SORLINI, S.; RONDI, L.; POLLMANN GOMEZ, A.; COLLIVIGNARELLI, C. Appropriate technologies for drinking water treatment in Mediterranean countries. Environmental Engineering and Management Journal, v. 14, n. 7, p. 1721-1733, 2015c.

SORLINI, S.; BIASIBETTI, M.; ABBÀ, A.; COLLIVIGNARELLI, M. C. Elaboration of a Water Safety Plan (WSP) for risk management in Mortara (PV) drinking water supply system. In: INTERNATIONAL SYMPOSIUM ON SANITARY AND ENVIRONMENTAL, 10., 19-23 June 2016, Rome, Italy. Proceedings... Balmain: TheMHS, 2016.

VIEIRA, P.; ALEGRE, H.; ROSA, M. J.; LUCAS, H. Drinking water treatment plant assessment through performance indicators. Water Science and Technology: Water Supply, v. 8, n. 3, p. 245-253, 2008. http://dx.doi.org/10.2166/ws.2008.068

WORLD HEALTH ORGANIZATION - WHO. Guidelines for Drinking-water Quality. 3rd ed. Geneva, 2004.

WORLD HEALTH ORGANIZATION - WHO; UNITED NATIONS CHILDREN'S FUND UNICEF. Progress on sanitation and drinking water: 2010 Update. Report of the Joint Monitoring Programme for Water Supply and Sanitation. Geneva; New York, 2010. 


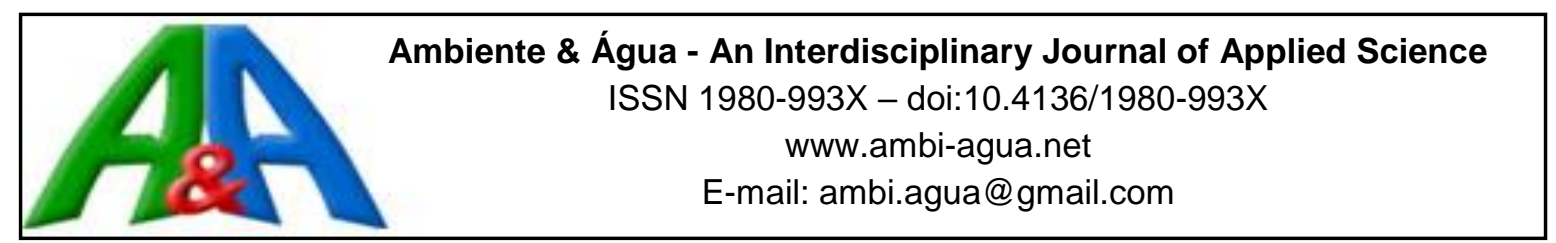

\title{
Sodium chloride as a reference substance for the three growth endpoints used in the Lemna minor L. (1753) test
}

\author{
doi:10.4136/ambi-agua.1986
}

Received: 18 Aug. 2016; Accepted: 20 Oct. 2016

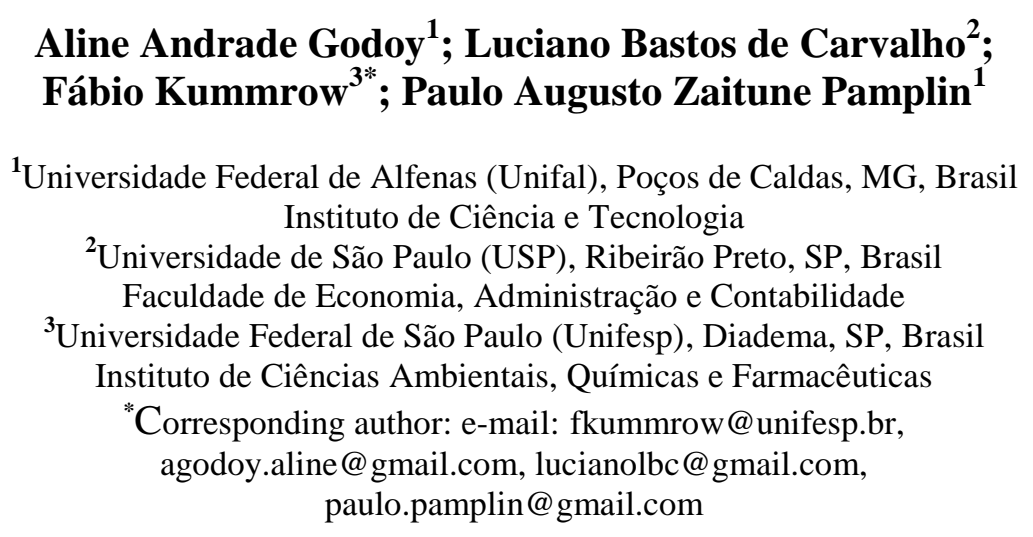

ABSTRACT

Lemna sp. growth inhibition test standardized protocols suggest the use of compounds such as 3,5-dichlorophenol as reference substances for checking the test organism's sensitivity routinely. However, this and other recommended chemicals present risks to human health and to the environment. Sodium chloride $(\mathrm{NaCl})$ appears as a less toxic alternative reference substance which has been successfully used in routine ecotoxicological tests. However, the evaluation of this compound in multiple growth endpoints used in the L. minor test, which is required for recommending it as a reference substance for this test organism, has not yet been reported. In the present study, $\mathrm{NaCl}$ was tested with $L$. minor for the growth endpoints frond number, total frond area and fresh weight. Results showed acceptable sensitivity and reproducibility (coefficient of variance $<15.0 \%$ ) for all three of the measured endpoints. Statistically significant differences were observed between the $\mathrm{EC}_{50}$ values calculated based on the three endpoints $(\mathrm{p}<0.05)$. Total frond area was the most sensitive one, with average $\mathrm{EC}_{50}$ value of $2742.80 \pm 245.7 \mathrm{mg} \mathrm{L}^{-1}$. It was anticipated that $\mathrm{NaCl}$ can be a suitable alternative reference substance and that total frond area should be the endpoint of choice for sensitivity toxicity tests using $\mathrm{NaCl}$.

Keywords: Duckweed, phytotoxicity, quality assurance.

\section{Cloreto de sódio como uma substância de referência para três parâmetros de crescimento usados no teste com Lemna minor L. (1753)}

\section{RESUMO}

Protocolos padronizados do teste de inibição de crescimento com Lemna sp. sugerem a utilização de compostos, tais como 3,5-diclorofenol, como substâncias de referência para verificar a sensibilidade dos organismos rotineiramente. No entanto, este e outros produtos químicos apresentam riscos para a saúde humana e para o meio ambiente. O cloreto de sódio 
$(\mathrm{NaCl})$ surge como uma substância de referência alternativa menos tóxica que tem sido utilizada com sucesso na rotina em testes ecotoxicológicos. No entanto, a avaliação deste composto em múltiplos parâmetros de crescimento utilizados no teste com $L$. minor, que é necessária para recomendá-lo como substância de referência para este organismo-teste, não foi ainda relatada. No presente estudo, $\mathrm{o} \mathrm{NaCl}$ foi testado com L. minor para os parâmetros de crescimento número de frondes, área total das frondes e peso fresco. Os resultados mostraram sensibilidade e reprodutibilidade aceitáveis (coeficiente de variação $<15,0 \%$ ) para todos os três parâmetros avaliados. Foram observadas diferenças estatisticamente significativas entre os valores de $\mathrm{CE}_{50}$ calculados com base nos três parâmetros $(\mathrm{p}<0,05)$. A área total das frondes foi o parâmetro mais sensível, com valor médio de $\mathrm{CE}_{50}$ de $2742,80 \pm 245,7 \mathrm{mg} \mathrm{L}^{-1}$. Estima-se que o $\mathrm{NaCl}$ pode ser uma substância de referência alternativa adequada e que a área total das frondes deve ser o parâmetro de escolha para testes de sensibilidade utilizando $\mathrm{NaCl}$.

Palavras-chave: Fitotoxicidade, garantia de qualidade, lentilha d'água.

\section{INTRODUCTION}

Reference substances are standard chemicals used to assess organisms' sensitivity in ecotoxicological tests and to establish essential test conditions for each species (Zagatto, 2008; Amorim et al., 2012). They are also used to assess the precision and reliability of data obtained by a laboratory for the selected reference toxicant (Canada, 2007). Therefore, using reference substances in laboratories of ecotoxicology must be a routine procedure in analytical quality assurance schemes (Zagatto, 2008).

The criteria desired in a reference substance and used in recommending the appropriate reference toxicants in standardized protocols include chemical readily available in pure form, stable shelf life of chemical, highly soluble in water, stability of the chemical in aqueous solution, analytical methods available to verify concentrations, good dose-response curve for the test organism, ease to perform, measurable effects on test endpoints and minimal hazard posed to user (Canada, 2007; Amorim et al., 2012). However, some of the reference substances indicated in standardized protocols may represent an important risk for the researcher, with some of them even presenting carcinogenic potential, e.g. potassium dichromate (IARC, 1990).

The OECD guideline for the testing of chemicals protocol 221 (OECD, 2006) recommends the use of reference substances such as 3,5-dichlorophenol as a chemical for checking the Lemna sp. growth inhibition test procedure. However, this compound may be harmful to human health causing severe irritations or burns of the eyes, skin and respiratory tract. 3,5-dichlorophenol chronic toxicity includes headache, neurological disturbances and liver and kidney damage (NLM, 2015). It also represents hazard to the environment, because it emits toxic fumes of carbon monoxide, carbon dioxide and hydrogen chloride gas when it is heated to decomposition (NOAA, 2015). Therefore, the use of alternative substances is necessary in order to avoid unnecessary risks to human health.

In this sense, sodium chloride $(\mathrm{NaCl})$ has been successfully used as an alternative reference substance for assessing the sensitivity of some species such as the midge Chironomus xanthus, the water flea Daphnia magna, the cnidarian Hydra attenuata and the freshwater green algae Raphidocelis subcapitata (Santos et al., 2007). The acceptable coefficients of variation (C.V.) obtained in those tests $(\leq 20.08 \%)$ indicated adequate reproducibility of results when $\mathrm{NaCl}$ was used as a reference toxicant for those species. Moreover, it must be highlighted that advantages in using this salt in sensitivity tests include its relative low cost, relatively low toxicity for human and the ease of disposal of wastes. 
Despite this, sensitivity and consistency of response to the $\mathrm{NaCl}$ effects have not been extensively assessed in tests using the macrophyte Lemna minor. An appropriate reference substance should be applicable to evaluate the sensitivity of multiple endpoints. However, the few data available in the literature concerning the $\mathrm{NaCl}$ toxicity effects for this test organism address just one endpoint, typically frond number (Chastinet and Silva, 2000; Keppeler, 2009; Souza et al., 2011). Although frond number is the primary measurement endpoint, the OECD guideline for the testing of chemicals protocol 221 (OECD, 2006) recommends measuring at least one other endpoint, such as total frond area and dry or fresh weight, since they may be affected in different intensities depending on the chemical tested.

It is also worthy to mention that, as stated by Pattard et al. (2009), the number of sensitivity tests performed for test systems other than algae, Daphnia sp. and luminescent bacteria is very limited. Therefore, additional reference data for test systems such as Lemna sp. can be a valuable source of information. L. minor is an important test organism commonly used for regulatory toxicity testing of chemicals. Therefore, growth inhibition tests performed with this macrophyte are very useful as an additional source of information about phytotoxicity for higher plants (Cleuvers, 2003).

The aim of the present study was to evaluate the sensitivity and the consistency of L. minor responses to $\mathrm{NaCl}$ as a reference substance on three growth endpoints indicated in the OECD 221 guideline (OECD, 2006) in order to provide $\mathrm{NaCl}$ toxicity data for multiple growth endpoints, including the ones generally neglected in routine tests, in order to contribute to the evaluation of the suitability of this compound as an alternative reference substance. In addition, the $\mathrm{EC}_{50}$ values obtained in the tests for frond number, total frond area and fresh weight were statistically compared in order to determine possible differences in sensitivity between the growth endpoints to the $\mathrm{NaCl}$ effects.

\section{MATERIAL AND METHODS}

\subsection{Test Chemical}

$\mathrm{NaCl}$ with $99.0 \%$ of purity was purchased from Vetec ${ }^{\circledR}$. The stock solutions used in the sensitivity tests were prepared by dissolving $\mathrm{NaCl}$ in Steinberg medium. The concentration of the stock solutions was $100 \mathrm{~g} \mathrm{~L}^{-1}$. Stock solutions were prepared immediately before each test. The nominal concentrations of $\mathrm{NaCl}$ used in the tests were 1,$500 ; 2,500 ; 3,500 ; 4,500 ; 5,500$; 6,500 and $7,500 \mathrm{mg} \mathrm{L}^{-1}$. Three replicates per treatment were used in all the tests.

\subsection{Cultivation of the Test Species}

L. minor was originally collected from cultivation tanks kept at Federal University of São Carlos (São Carlos-SP, Brazil). For long-term cultivation, the macrophytes were periodically sterilized in sodium hypochlorite solution followed by sterile water (OECD, 2006). Prior to experiment for sensitivity testing, the plants were allowed to adapt to the culture medium Steinberg (OECD, 2006) for a 3-week period. The macrophytes were cultured in glass crystallizer filled with $2 \mathrm{~L}$ Steinberg medium ( $\mathrm{pH} 5.5$ ), kept in a climate chamber at $24 \pm 2{ }^{\circ} \mathrm{C}$ with a photoperiod of $12 \mathrm{~h}$ light/12 $\mathrm{h}$ dark instead of continuous lighting in order to provide conditions closer to the environment (Godoy et al., 2015). Light intensity used was 6550 lux (104.8 $\mu \mathrm{mol}$ photons $/ \mathrm{m}^{2} \mathrm{~s}^{-1}$ ). Once a week a number of young, light-green plants were removed to fresh medium aseptically. The culture vessel was covered with plastic film having perforations of approximately $1 \mathrm{~mm}$ diameter to minimize evaporation and to avoid contamination, while allowing adequate air exchange. Only young, rapidly growing plants without visible lesions or chlorosis were selected for the tests. 


\subsection{Test Performance}

Sensitivity tests were carried out according to OECD guideline 221 for the testing of chemicals - Lemna sp. growth inhibition test (OECD, 2006). The temperature and photoperiod conditions used in the sensitivity tests were the same ones used in the cultivation. The tests were carried out in $250 \mathrm{~mL}$ beakers filled with $100 \mathrm{~mL}$ of test solution. Inoculum for each beaker was 12 fronds using only macrophytes with three fronds, all of them with similar total area. Three control and treatment replicates were performed for each test concentration. The test period was 7 days (168 h). Eight independent assays were performed. After exposure, the specific growth average rates were calculated based on the endpoints frond number, total frond area and fresh weight. In addition, visual changes in plant development, e.g., chlorosis, necrosis and colony break-up, were observed and registered.

Frond number was counted daily using a stereomicroscopic (Zeiss ${ }^{\circledR}$, Stemi 2000-C model), at 80-fold increase. The fresh weight was calculated at the end of the tests using an analytical balance after removing excess moisture by placing the macrophytes between layers of paper towels. The difference between the weight of the plant material at the beginning and at the end of the experiments was calculated according to OECD (2006) in order to determine the fresh weight. The $\mathrm{pH}$ was measured at the beginning and at the end of the tests.

For the calculation of the total frond area, the test organisms were photographed at days $0,3,5$ and 7 with a digital camera alongside a $1-\mathrm{x} 1-\mathrm{cm}$ red paper square (standard comparison scale). All the images were handled through the GIMP (GNU Image Manipulation Program, 2.8.14) free software (Godoy et al., 2015). Any visual signs of phytotoxicity were observed and registered.

\subsection{Statistical Analysis}

ECx-values (effect concentration at $\mathrm{x} \%$ level) and respective $95 \%$ confidence intervals were calculated for all the three endpoints assessed in the sensitivity tests based on the specific growth rates compared to the respective controls, according to OECD (2006). These values were determined with the free software ToxCalcMix (Barata et al., 2006), using nonlinear curve fitting based on a sigmoid model (three-parameter logistic function). Statistically significant differences between the endpoints frond number, total frond area and fresh weight were tested using a one-way ANOVA followed by the Scott-Knott's multiple comparison test $(\mathrm{P}<0.05)$. Prior to perform ANOVA, the data were tested for normality using Shapiro-Wilk test with the free software SISVAR 5.3.

\section{RESULTS AND DISCUSSION}

The $\mathrm{pH}$ of the control medium did not increase by more than 1.5 units during the test (5.5 - 6.8), as recommended by the 221 OECD guideline (OECD, 2006). The $\mathrm{EC}_{50}$ values and their respective $95 \%$ confidence intervals for the growth endpoints frond number, total frond area and fresh weight are summarized in the Table 1.

The frond number is the most commonly used endpoint to express duckweed test results because its evaluation is simple, rapid and noninvasive (Wang et al., 1990). Regarding the average $\mathrm{EC}_{50}$ result obtained in this study for this endpoint (Table 1), the value is similar to the average $\mathrm{EC}_{50-7}$ days value of $4,308 \mathrm{mg} \mathrm{L}^{-1}$ obtained by Souza et al. (2011) under similar test conditions as used in this study, except for the culture medium applied (Hoagland medium instead of Steinberg medium). $\mathrm{EC}_{50}$ values for the other two growth endpoints were quite lower and results from the one-way ANOVA test indicated that there was a statistically significant difference between the sensitivities of the evaluated endpoints to the $\mathrm{NaCl}$ effects ( $\mathrm{p}<0.05)$. However, the growth rate of L. minor was significantly decreased at the LOEC of $1,500 \mathrm{mg} \mathrm{L}^{-1}$ for all three of the evaluated endpoints (Figure 1) (A, B, C). 
Table 1. $\mathrm{EC}_{50}$ values $\left(\mathrm{mg} \mathrm{L}^{-1}\right)$ obtained for the endpoints frond number, total frond area and fresh weight in $L$. minor growth inhibition test with $\mathrm{NaCl}$, calculated from average specific growth rates. In brackets are indicated the $95 \%$ confidence intervals estimated for $\mathrm{EC}_{50}$ point estimates.

\begin{tabular}{|c|c|c|c|}
\hline & \multicolumn{3}{|c|}{ Endpoint } \\
\hline & Frond number & Fresh weight & Total frond area \\
\hline Test number & & $\mathrm{EC}_{50}{ }^{\mathrm{a}}$ values & \\
\hline 1 & $3810.86(257.40)$ & $2789.95(301.29)$ & $2514.59(163.07)$ \\
\hline 2 & $3689.86(245.68)$ & 3132.79 (218.28) & 2975.07 (166.10) \\
\hline 3 & $3916.76(181.83)$ & $2768.48(355.16)$ & $2569.38(235.46)$ \\
\hline 4 & 3674.81 (158.17) & $2411.81(357.24)$ & 2589.96 (197.77) \\
\hline 5 & $4245.57(140.75)$ & $3728.82(291.81)$ & $2836.52(195.82)$ \\
\hline 6 & $4280.01(233.93)$ & $3619.80(201.98)$ & $3200.46(164.78)$ \\
\hline 7 & $4159.25(263.41)$ & 3441.31 (378.17) & $2724.99(243.20)$ \\
\hline 8 & $4074.54(265.45)$ & $3295.43(249.38)$ & $2531.44(355.16)$ \\
\hline Average ( \pm S.D. $\left.{ }^{b}\right)$ & $3981.46(242.46)$ & $3148.55(460.15)$ & $2742.80(245.73)$ \\
\hline C.V. ${ }^{c}(\%)$ & 6.09 & 14.61 & 8.96 \\
\hline
\end{tabular}

${ }^{\mathrm{a}} \mathbf{E C}_{\mathbf{5 0}}$ - Effect concentration at a $50 \%$ level;

${ }^{b}$ S.D. - Standard deviation; and

${ }^{\mathbf{c}}$ C.V. - Coefficient of variation.
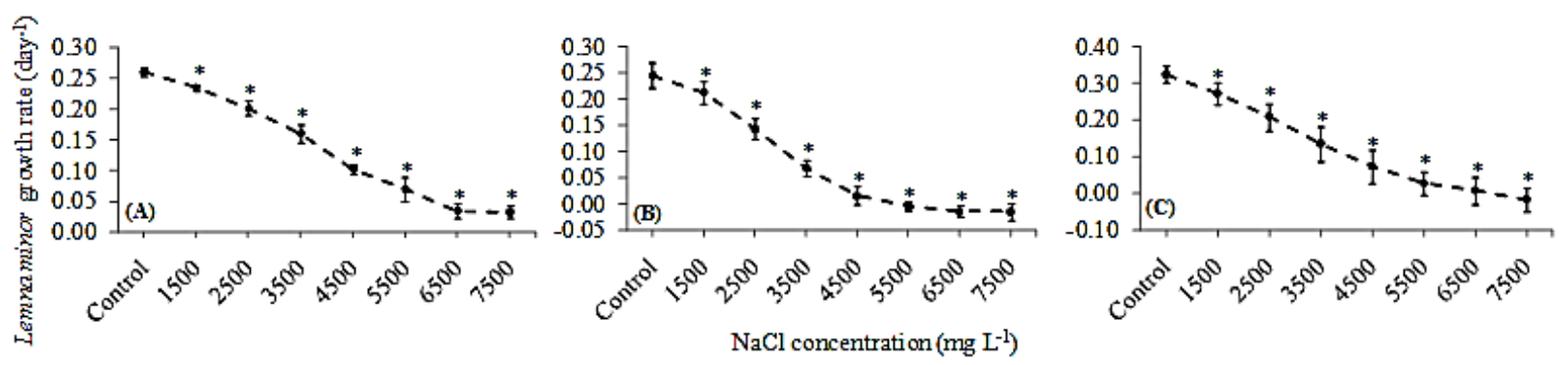

Figure 1. Growth rates of $L$. minor based on different endpoints upon exposure to increasing concentrations of the reference substance $\mathrm{NaCl}$ : (A) frond number; (B) total frond area; (C) fresh weight. Standard deviation is indicated by the vertical bars on each circle. Asterisks refer to a significant difference from the control $(\mathrm{p}<0.05)$.

The C.V. values obtained for all three of the growth endpoints evaluated in this study were lower than $15.0 \%$, indicating a relatively consistent response to $\mathrm{NaCl}$, since in Environment Canada guidelines there are advisements that variation in a set of test results of a reference substance must be preferably $\leq 20 \%$ (Donnevert et al., 2009). Buckley et al. (1996) also found a relatively low C.V. value of $5.8 \%$ in four tests carried out using L. minor dry weight as an endpoint in order to assess the $\mathrm{NaCl}$ toxic effects. These results indicate that stable variance measures can be obtained for independent sensitivity tests with L. minor, based on growth endpoints, using the $\mathrm{NaCl}$ as a reference substance.

Comparing the $\mathrm{EC}_{50}$ values obtained in this study using $\mathrm{NaCl}$ with results reported for the reference substance 3,5-dichlorophenol, which is indicated in OECD and Environment Canada protocols (Canada, 2007; OECD, 2006), allows one to conclude that L. minor is more sensitive to the effects posed by this last compound. Results from reference tests performed in the EU Waste Ring Test 2006/2007 for 3,5-dichlorophenol in L. minor growth inhibition tests ranged from 2.20 to $3.50 \mathrm{mg} \mathrm{L}^{-1}$, with mean value of $2.77 \pm 0.44 \mathrm{mg} \mathrm{L}^{-1}$ (Pattard et al., 2009). Thus, the required range for the $\mathrm{EC}_{50}$ values determined in tests with L. minor using this reference toxicant is 1.8 to $3.6 \mathrm{mg} \mathrm{L}^{-1}$ (Pattard et al., 2009). ISO 20079 (ISO, 2006) 
establishes a narrower range as validity criteria for this compound, of an $\mathrm{EC}_{50}$ (frond number) of $2.2-3.8 \mathrm{mg} \mathrm{L}^{-1}$. Based on an international ring-test including laboratories from several global regions, 3,5-dichlorophenol has been recommended for use in sensitivity tests with L. minor as it showed the best result (OECD, 2002). However, the important criteria of safety to user should have been also observed before recommending this reference substance. Chlorophenol compounds can cause severe human toxic effects, including cancer (NLM, 2015). Furthermore, disposal of its residues is another problem to be considered, since 3,5-dichlrorophenol can bioconcentrate in aquatic organisms, being toxic to them with possible long-term adverse effects (Zagorc-Koncan et al., 2002; NLM, 2015).

Canada (2007) recommends using reagent-grade nickel $(\mathrm{Ni})$, in the form of nickel sulphate $\left(\mathrm{NiSO}_{4} \cdot 6 \mathrm{H}_{2} \mathrm{O}\right)$, in reference toxicity tests with L. minor. According to that protocol, $\mathrm{Ni}$ was considered favorable due to the relatively steep dose response curve produced in reference toxicity tests performed with the macrophyte. Visual toxicity signs caused by $\mathrm{Ni}$ at concentrations $>3.0 \mathrm{mg} \mathrm{L}^{-1}$ include chlorosis, necrosis and frond disconnection (Khellaf and Zerdaoui, 2009). Those phytotoxicity signs are similar to the ones observed in this study in the macrophytes exposed to concentrations $\geq 4,500 \mathrm{mg} \mathrm{L}^{-1}$ of $\mathrm{NaCl}$ (Figure 2) (A, B, C, D, E).

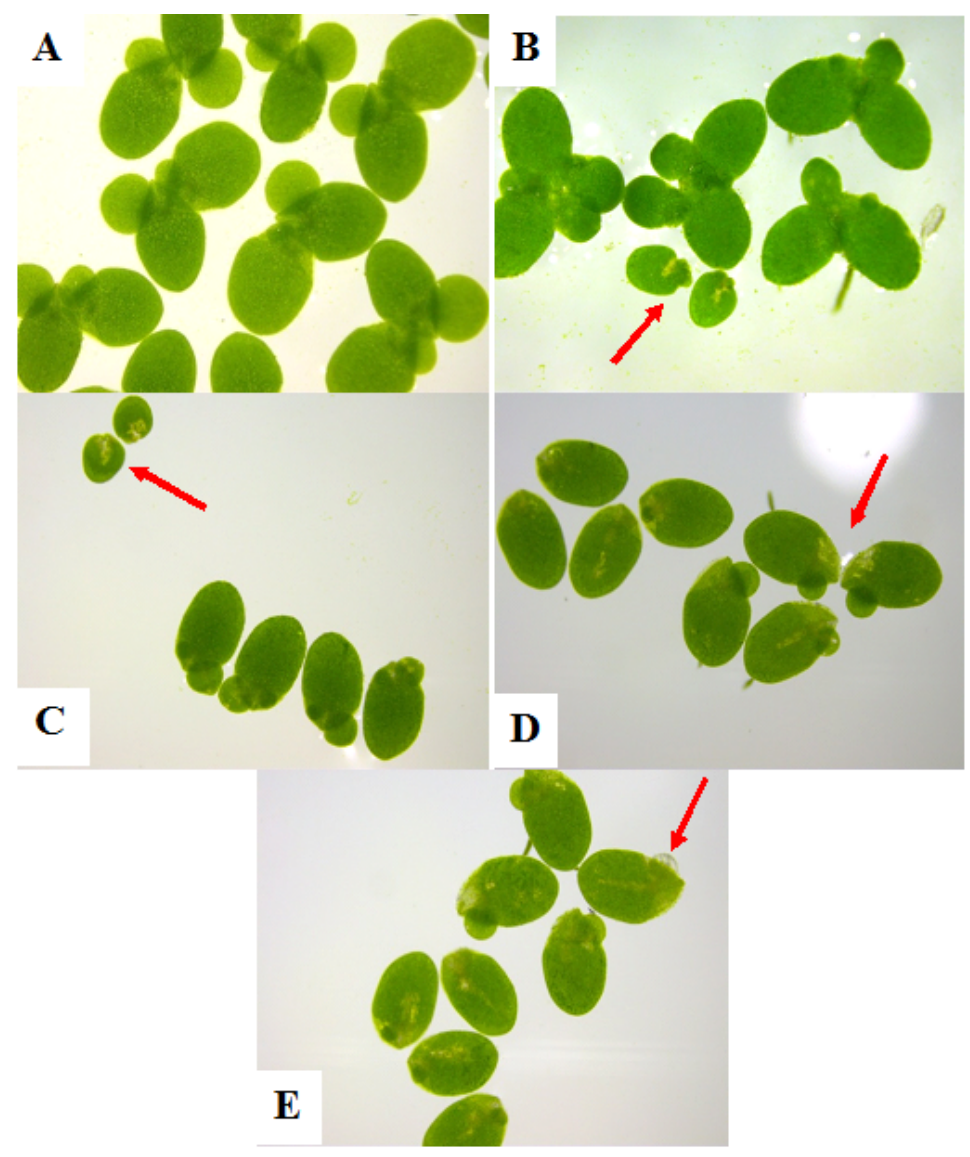

Figure 2. Macroscopic signs of phytotoxicity of $L$. minor fronds exposed to several concentrations of $\mathrm{NaCl}$ : (A) Plants exposed to the control showing fronds without visual phytotoxicity signs; (B) Beginning of frond disconnection and of chlorosis signs in plants exposed to the concentration of 4,500 $\mathrm{mg} \mathrm{L}^{-1}$; (C) and (D) Total frond disconnection and chlorosis signs in plants exposed to the concentrations of $5,500 \mathrm{mg} \mathrm{L}^{-1}$ and 6,500 $\mathrm{mg} \mathrm{L}^{-1}$ respectively; (E) Necrosis observed in frond exposed to the concentration of $7,500 \mathrm{mg} \mathrm{L}^{-1}$. 
Therefore, similar phytotoxicity signs can be observed for the reference toxicant $\mathrm{Ni}$ in lower concentrations compared to the ones observed for $\mathrm{NaCl}$. However, two major problems can be highlighted regarding Ni. First, the requirement that the culture medium used in tests with $\mathrm{Ni}$ compounds contains no EDTA restricts the choice of the dilution water to the modified APHA medium, whereas the use of other recommended and commonly used test medium such as Steinberg and Swedish Standard (OECD, 2002) is not possible. Moreover, Ni compounds are considered carcinogenic to humans (IARC, 1990).

Considering the important human safety issue, Canada (2007) suggests potassium chloride $(\mathrm{KCl})$ as another possible reference substance for using in L. minor routine toxicity tests. ISO 20079 (ISO, 2006) suggested that $\mathrm{EC}_{50}$ based on frond number should be in a range between 5,500 and $10,000 \mathrm{mg} \mathrm{L}^{-1}$ for $\mathrm{KCl}$ in reference toxicity tests with $L$. minor. Canada (2007) reported a lower mean $\mathrm{EC}_{50}$ value of $4,770 \mathrm{mg} \mathrm{L}^{-1}(\mathrm{n}=18)$ and a $\%$ C.V. of $15.9 \%$ for this compound in tests with this macrophyte. Therefore, mean $\mathrm{EC}_{50}$ value of $3,981 \mathrm{mg} \mathrm{L}^{-1}$ obtained in this study for $\mathrm{NaCl}$ (considering the same endpoint frond number) is slightly lower than the mean $\mathrm{EC}_{50}$ value reported for $\mathrm{KCl}$ in the Environment Canada protocol (2007). Moreover, it must be highlighted that $\mathrm{NaCl}$ presents the same advantages desired in a reference substance of stability in storage, stability in solution and safety to the user as observed for $\mathrm{KCl}$ (Sigma Aldrich, 2016).

$\mathrm{NaCl}$ was found to be suitable for evaluating the sensitivity based on growth endpoints other than frond number, which is required by OECD 221 (OECD, 2006). Regarding the evaluation of the other growth endpoints, the total frond area was the most sensitive one according to the Scott-Knott's multiple comparison tests performed. As it occurs with frond number, total frond area also is relatively easy to perform in vivo and allow measurements over all the time of the experiment. Moreover, evaluation of total frond area overcomes the problem pointed out by Wang (1990), who stated that frond count is irrelevant to frond size or biomass and therefore it can roughly underestimate the toxic effect to duckweed.

\section{CONCLUSION}

To the best of our knowledge, this is the first study to generate reference data for the $\mathrm{NaCl}$ toxic effects by measuring simultaneously three growth endpoints recommended in Lemna sp. guidelines. Therefore, we have expanded the results published in the literature regarding the $\mathrm{NaCl}$ toxicity for $L$. minor, since we have evaluated additional endpoints neglected in routine tests, such as total frond area and fresh weight.

The results presented in this study show that $\mathrm{NaCl}$ can be a suitable alternative reference substance for routine toxicity tests using $L$. minor since the tests performed with this salt presented acceptable sensitivity and reproducibility, measured in multiple growth endpoints. Mean $\mathrm{EC}_{50}$ value obtained for $\mathrm{NaCl}$ based on frond number were somewhat lower than the mean $\mathrm{EC}_{50}$ reported in standardized protocols for $\mathrm{KCl}$. Moreover, this compound has the advantages of being less hazardous to both human health and the environment than other commonly used reference substances recommended by standardized protocols, such as 3,5-dichlorophenol and Ni compounds.

Moreover, we were able to demonstrate that there are significant differences in the sensitivity among L. minor growth endpoints for the $\mathrm{NaCl}$ effects. Our results clearly showed that the L. minor total frond area is a more sensitive endpoint for the $\mathrm{NaCl}$ effects than the commonly used endpoint frond number. Therefore, considering the advantage of higher sensitivity compared to frond number, we recommend that total frond area should be actually the endpoint of choice when assessing $L$. minor growth inhibition in routine sensitivity tests using $\mathrm{NaCl}$ as an alternative reference substance. 


\section{REFERENCES}

AMORIM, M. J. B.; NATAL-DA-LUZ, T.; SOUSA, J. P.; LOUREIRO, S.; BECKER, L.; RÖMBKE, J. et al. Boric acid as reference substance: pros, cons and standardization. Ecotoxicology, v. 21, p. 919-924, 2012. http://dx.doi.org/10.1007/s10646-011-0832-9

BARATA, C.; BAIRD, D. J.; NOGUEIRA, A. J. A.; SOARES, A. M. V. M.; RIVA, M. C. Toxicity of binary mixtures of metals and pyrethroid insecticides to Daphnia magna Straus. Implications for multi-substance risks assessment. Aquatic Toxicology, v. 78, p. 1-14, 2006. http://dx.doi.org/10.1016/j.aquatox.2006.01.013

BUCKLEY J. A.; RUSTAGI K. P.; LAUGHLIN, J. D. Response of Lemna minor to sodium chloride and a statistical analysis of continuous measurements for $\mathrm{EC}_{50}$ and $95 \%$ confidence limits calculation. Bulletin of environmental contamination and toxicology, v. 57, p. 1003-1008, 1996. http://dx.doi.org/10.1007/s001289900290

CANADA. Environment And Climate Change. Biological test method: test for measuring the inhibition of growth using the Freshwater Macrophyte, Lemna minor - method development and applications section. Ottawa, Canada: Environmental Technology Centre, 2007.

CHASTINET, C. B. A.; SILVA E. M. Comparação da sensibilidade de duas linhagens de Lemna minor ao cloreto de sódio $(\mathrm{NaCl})$ como substância de referência. In: ESPÍNDOLA, E. L. G. Ecotoxicologia: Perspectivas para o século XXI. São Carlos: RiMA, 2000. p. 557-566.

CLEUVERS, M. Aquatic ecotoxicity of pharmaceuticals including the assessment of combination effects. Toxicology letters, v. 142, p. 185-194, 2003. http://dx.doi.org/10.1016/S0378-4274(03)00068-7

DONNEVERT, G.; UHLIG, S.; MOSER, T. Ring Test Data Evaluation. In: MOSER, H.; RÖMBKE, J. (Eds.). Ecotoxicological characterization of waste: results and experiences of an international ring test. New York: Springer Science; Business Media; 2009. p. 47-60.

GODOY, A. A.; KUMMROW, F.; PAMPLIN, P. A. Z. Ecotoxicological evaluation of propranolol hydrochloride and losartan potassium to Lemna minor L. (1753) individually and in binary mixtures. Ecotoxicology, v. 24, p. 1112-1123, 2015. http://dx.doi.org/10.1007/s10646-015-1455-3

INTERNATIONAL AGENCY FOR RESEARCH ON CANCER. IARC monographs on the Evaluation of Carcinogenic Risks to Human - Chromium, nickel and welding. Vol. 49. Lyon, 1990.

INTERNATIONAL ORGANIZATION FOR STANDARDIZATION. ISO 20079 - Water quality - Determination of the toxic effect of water constituents and waste water on duckweed (Lemna minor) - Duckweed growth inhibition test. Genebra, 2006.

KEPPELER, E. C. Toxicity of sodium chloride and methyl parathion on the macrophyte Lemna minor (Linnaeus, 1753) with respect to frond number and chlorophyll. Biotemas, v. 22, p. 27-33, 2009. 
KHELLAF. N.; ZERDAOUI, M. Growth response of the duckweed Lemna minor to heavy metal pollution. Journal of Environmental Health Science and Engineering, v. 6, n. 3, p. 161-166, 2009.

NATIONAL LIBRARY OF MEDICINE - NLM (U.S.). Toxicology Data Network. Available in: https://goo.gl/WXnvoj. Access in: Aug. 2015.

NATIONAL OCEANIC AND ATMOSPHERIC ADMINISTRATION - NOAA. Database of Hazardous Materials. CAMEO Chemicals version 2.4.2. Available in: https://goo.gl/MeJU8G. Access in: July 2015.

ORGANIZATION FOR ECONOMIC CO-OPERATION AND DEVELOPMENT - OECD. Lemna sp. Growth inhibition test. In: Guidelines for the Testing of chemicals. Draft Guideline 221. Paris, 2002.

ORGANIZATION FOR ECONOMIC CO-OPERATION AND DEVELOPMENT - OECD. Lemna sp. Growth inhibition test. In: Guidelines for the Testing of chemicals. Updated Test Guideline 221. Paris, 2006.

PATTARD, M.; RÖMBKE, J.; MOSER, T. Range of Reference Tests in Aquatic Tests. In: Ecotoxicological characterization of waste: results and experiences of an international ring test. New York: Springer Science; Business Media, 2009. p. 61-70.

SANTOS, M. A. P. F.; VICENSOTTI, J.; MONTEIRO, R. T. R. Sensitivity of four test organisms (Chironomus xanthus, Daphnia magna, Hydra attenuata and Pseudokirchneriella subcapitata) to $\mathrm{NaCl}$ : an alternative reference toxicant. Journal of the Brazilian Society of Ecotoxicology, v. 2, p. 229-236, 2007.

SIGMA-ALDRICH. Product Information: Sodium chloride. Catalog numbers S7653, S9625, S9888. Available in: http://www.sigmaaldrich.com. Access in: January 2016.

SOUZA, J. P.; MEDEIROS, L. S.; WINKALER, E. U.; MACHADO-NETO, J. G. Acute toxicity and environmental risk of diflubenzuron to Daphnia magna, Poecilia reticulata and Lemna minor in the absence and presence of sediment. Pesticidas: Revista de Ecotoxicologia e Meio Ambiente, v. 21, p. 1-12, 2011.

WANG, W. Literature review on duckweed toxicity testing. Environmental Research, v. 52, p. 7-22, 1990. http://dx.doi.org/10.1016/S0013-9351(05)80147-1

ZAGORC-KONCAN, J.; ZGAJNAR, G. A.; TISLER, T. Hazard identification for 3,5dichlorophenol in the aquatic environment. Cellular and Molecular Biology Letters, v. 7, p. 381-382, 2002.

ZAGATTO, P. A. O uso de substâncias de referência no controle de qualidade de ensaios ecotoxicológicos. In: ZAGATTO, P. A.; BERTOLETTI E. Ecotoxicologia aquática: princípios e aplicações. São Carlos: RiMa; 2008. p. 185-197. 


Ambiente \& Água - An Interdisciplinary Journal of Applied Science
ISSN 1980-993X - doi:10.4136/1980-993X
www.ambi-agua.net
E-mail: ambi.agua@gmail.com

\title{
Sediments of watersheds from Frutal and Bebedouro Streams (Frutal, MG, Brazil) as an indicator of human activities
}

\author{
doi:10.4136/ambi-agua.1978
}

Received: 01 Aug. 2016; Accepted: 18 Oct. 2016

\author{
Sofia Luiza Brito ${ }^{*}$; Thiago Torres Costa Pereira ${ }^{2}$; Inez Cristina Martins ${ }^{2}$ \\ ${ }^{1}$ Fundação Centro Internacional para Educação, Capacitação e Pesquisa Aplicadas em Águas \\ (UNESCO-HidroEX), Frutal, MG, Brasil \\ Diretoria de Pesquisa \\ ${ }^{2}$ Universidade do Estado de Minas Gerais (UEMG), Frutal, MG, Brasil \\ Departamento de Ciências Exatas e da Terra \\ *Autor correspondente: e-mail: sofialuizabrito@gmail.com, \\ thiago.solos@gmail.com,inezcmartins@gmail.com
}

\begin{abstract}
Soil degradation is a physical process intensified by political and socioeconomic factors, and by the population growth of the $20^{\text {th }}$ century. In this study, we evaluated the sediments of the Frutal and Bebedouro Streams, located in Frutal municipality, Minas Gerais State, Brazil, and their relation to major human activities that are responsible soil erosion and silting. Samples were collected between 2012 and 2013 for the determination of granulometric composition, organic matter content, and minerals in sediments. The Wentworth scale was used for particle size measurement, and then the size classes regrouped to ABNT scale (NBR 6502/1995). The results found that agriculture and cattle ranching are the main activities that cause intense erosion and silting in both watersheds. Bebedouro Stream is better preserved, as it is completely located in rural area with larger riparian vegetation, unlike the mid-stretch of Frutal Stream, which is located in an urban area. Quartz is the predominant mineral in the sediments as the soils of the region are formed by sandstones; consequently, few nutritional elements were found in the studied samples. Principal component analysis showed that water quality parameters are correlated to silt/clays and organic matter content in most of the collected stations.
\end{abstract}

Keywords: cerrado, rhodic ferralsols, soil erosion.

\section{Sedimentos das microbacias do Ribeirão Frutal e Córrego Bebedouro (Frutal, MG) como indicador da ação antrópica}

\section{RESUMO}

A degradação do solo é um processo físico intensificado por fatores políticos e socioeconômicos, acentuado drasticamente pelo crescimento da população no século $\mathrm{XX}$. $\mathrm{O}$ objetivo deste estudo foi avaliar os sedimentos do Ribeirão Frutal e Córrego Bebedouro, localizados no município de Frutal, Minas Gerais, Brasil, e sua relação com as principais atividades humanas que são responsáveis pelo processo avançado de erosão do solo e assoreamento. Foram coletadas amostras entre 2012 e 2013 para determinar a composição granulométrica, teor de matéria orgânica e sais minerais encontrados nos sedimentos. Para a 
medição do tamanho das partículas, foi utilizada a escala de Wentworth e, posteriormente, as classes de tamanho foram reagrupadas para a escala ABNT (NBR 6502/1995). De acordo com os resultados, a agricultura e a pecuária são as principais atividades que causam erosão acelerada e assoreamento em ambas as bacias hidrográficas. O Córrego Bebedouro é melhor preservado, uma vez que se encontra totalmente inserido na área rural, com mata ciliar melhor preservada do que o trecho médio do Ribeirão Frutal, localizado na área urbana. O quartzo é o mineral predominante nos sedimentos devido ao solos da região serem formados por arenitos, consequentemente, com poucos elementos nutricionais. A análise de componentes principais mostrou que parâmetros de qualidade da água estão correlacionados com a fração silte/argila e matéria orgânica na maioria das estações.

Palavras-chave: cerrado, erosão do solo, latossolo vermelho.

\section{INTRODUCTION}

Soil degradation is a physical process intensified by political and socioeconomic factors and has been accentuated drastically by $20^{\text {th }}$ century population growth (Lal, 2001). In watersheds with natural forest cover, vegetation protects against soil erosion, silting, and excessive nutrient leaching, the riparian zone is a very important area to help maintain the water supply's quantity and quality (Morgan, 2005). On the other hand, practices that follow after removal of the original vegetation tend to produce intense and prolonged degradation of water quality (Klink and Machado, 2005).

Sediments are an important compartment of the aquatic environment, and result from interacting processes that occur in a water catchment. For this reason, they are an essential tool for the study of the manner and intensity of impacts to which surrounding terrestrial ecosystems are or have been subjected (Esteves, 2011).

Currently, there are several impacts in the natural environments, particularly in the Brazilian Tropical Savanna (Cerrado), resulting from the Green Revolution that has occurred in Brazil since the 1960s. In this case, the agricultural intervention in the soils of the Frutal region (MG) is marked in many cases by inadequate management, which accelerates erosion, and often results environmental degradation that is difficult to reverse.

The use of modern agricultural technology and intensive use of the soil beyond its carrying capacity has been shown to be key factor in increasing erosion and expansion of degraded Cerrado areas. It may be a future risk to food production and security, particularly for low-income farmers. Thus, the intensive use of mechanization, fertilizers and pesticides compromises the pedological cover, the watersheds and the agricultural ecosystems themselves.

According to Cunha et al. (2008), the main threat to biodiversity in the Cerrado is the expanding of agricultural frontier, which has been made by loss of original vegetation converted to croplands and pasture. This expansion of agriculture has occurred with intensive use of pesticides and fertilizers, uncontrolled irrigation, compaction of soil by cattle ranching, extensive monoculture (traffic of heavy vehicles) and increasing of landholdings.

Former studies in Frutal and Bebedouro watersheds showed degradation of environment by removal of riparian vegetation, high erosive rates, silting and organic material present in the riverbeds of two streams (Ferreira, 2005; Souza, 2009). Both watersheds present laminar erosion and soil depletion under pasture, increased by runoff from rural roads. There are also records of erosion in rills: three large gullies in the Frutal watershed, the largest of them occupying an area of approximately 15 ha (Cardoso, 2008).

Factors such as drainage and soil structure, associated with a flat relief and the presence of several streams, are the main conditions for intensive agricultural use in the Frutal region. Despite the importance of soils to the Cerrado's survival, little attention has been given to 
their use and conservation since the area was first occupied. Soil conservation begins with vegetation maintenance, to minimize the impact of droplets during rainfall and thus reduce the formation of rills in the soil, consequently reducing erosion (Morgan, 2005).

The aim of this study was to evaluate the sediments of the Frutal and Bebedouro Streams, located in Frutal municipality, Minas Gerais State, Brazil, and their relation to major human activities that are responsible for advancing the process of soil erosion, silting and water quality degradation.

\section{MATERIALS AND METHODS}

\subsection{Study Area}

Frutal municipality is located in meso-region of Triângulo Mineiro, Minas Gerais State, with an economy based mainly upon agricultural activity, especially sugar cane $(65 \%)$ and cattle ranching, with about 190,000 heads (IBGE, 2014). Cattle usually have access to rivers for watering, and their excessive trampling was widely diagnosed as being the cause of some erosive processes that occur in the study area.

The watersheds of Frutal (S 19 $55.941^{\prime}$ W $48^{\circ} 55.427,124.2 \mathrm{~km}^{2}$ ) and Bebedouro Streams (S 1957.064' W 48 $57.775^{\prime}, 165.0$ km²), belong to the Grande River Basin (MG/SP States), flowing into the Marimbondo Reservoir (Furnas Company S/A). Since 1976, the water supply for the municipalities have come from the Frutal Stream (Varanda, 2007), where the urban area and road BR-364 already reach the watershed, upstream of the water catchment. Downstream of the urban area effluents from the sewage treatment plant discharge into Frutal Stream.

The Frutal region has tropical weather, with a well-defined dry season. Annual mean precipitation varies between 1,400 and $1,500 \mathrm{~mm}$, with rains concentrated in the period between October and March. The relief comprises the Plateau of Paraná Sedimentary Basin. It is an extension, in Minas Gerais, of formations that occupy large areas in São Paulo, Paraná, Santa Catarina and Rio Grande do Sul States, and corresponds to the sedimentary layers on basaltic lava flows. The stratigraphic sequence in Frutal is marked by basalts of the Serra Geral Formation ( \pm 120 million years ago) over which occur sandstones of the Vale do Rio do Peixe Formation $( \pm 80$ million years ago) and sandstones and conglomerates of the Marília Formation ( \pm 70 million years ago) (CPRM and SGMB, 2003).

Beneath the Cerrado vegetation, Dystric Rhodic Ferralsols (Typical) of medium texture predominate in the watersheds. They are deep soils, well-drained and with high aluminum content. Currently, these soils are widely used to cultivate sugar cane, corn, sorghum, soybeans, irrigated pineapple crops, grazing, rubber tree, and others annual crops.

Soil classes like Haplic Cambisols, Haplic Lixisols and Arenosols also occur. Systems of Tropical Wet Savanna (Veredas) occur in hydromorphic environments.

\subsection{Proceedings}

Samplings were taken in dry (September/2012) and rainy seasons (March/2013). A third sampling (August/2013) was taken for X-ray mineralogical analyses. Sediment samples were collected at 28 stations: 19 in Frutal Stream, 8 in Bebedouro Stream, and 1 at Station J - the union of the streams (Figure 1). In Frutal Stream, more sampling stations were used because its watershed has more tributaries, which provide the city's water supply and suffer severe impacts of the adjacent urban area and road BR-364. To assess possible effects of the tributaries, the samples were taken as close as possible to the mouths of the tributaries. In Frutal Stream, the tributaries are represented by Stations F2, F7, F9, F11, F17, while in the Bebedouro Stream, with only two tributaries are the B4 and B7 Stations.

Sampling Stations R1 (degraded headwater) and R2 (preserved headwater) were named 
separately for hydrodynamic studies, but they were considered altogether for sediment studies. Vertente Grande Stream (stations F14 to F17) deserves attention because it is responsible for the drainage of the urban area. In Bebedouro Stream, Station B7 is the most impacted, without riparian vegetation. Stations J, B8 and F13 are located in a flooded area of Marimbondo reservoir.

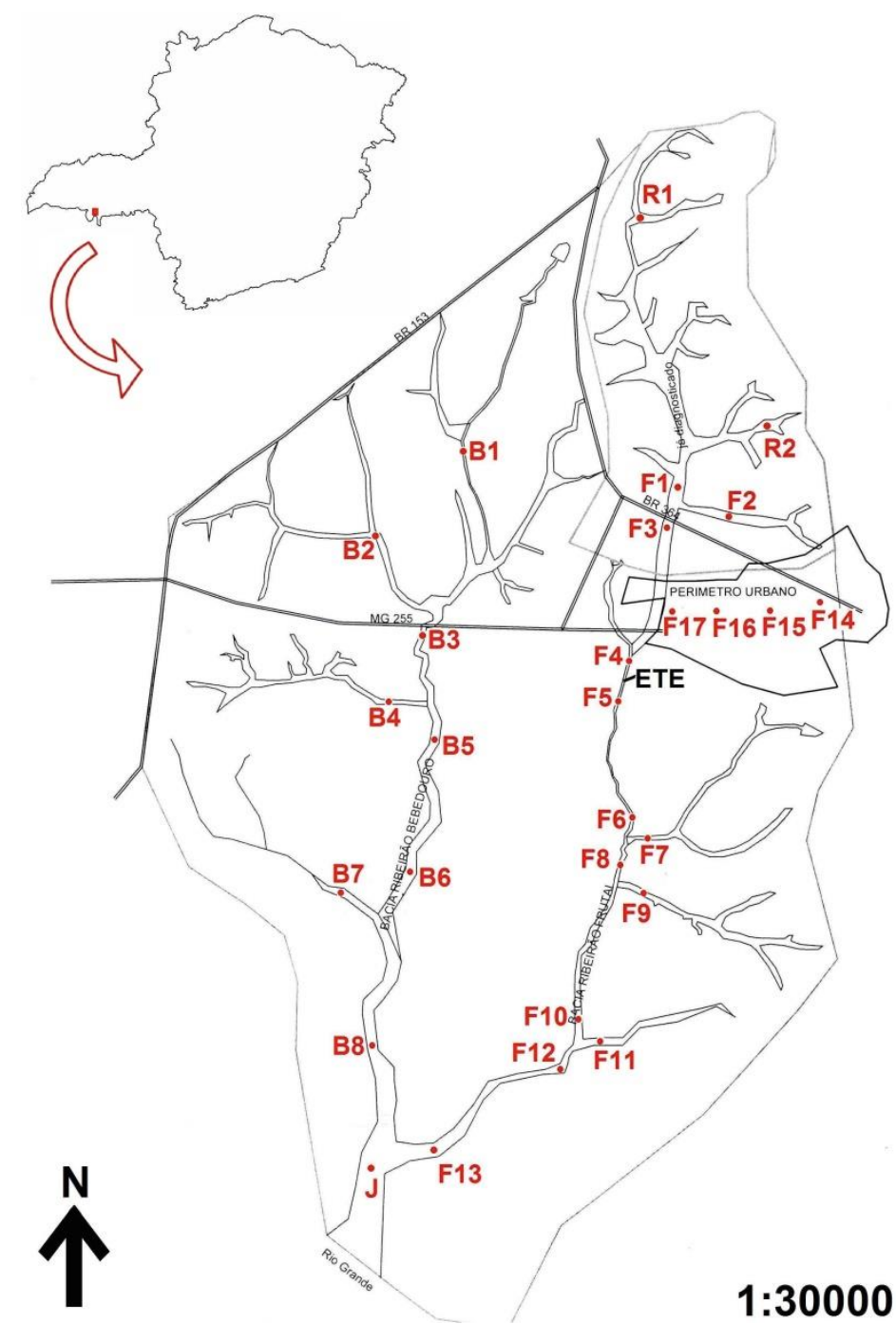

Figure 1. Station samplings in watersheds of Frutal and Bebedouro Streams, Frutal municipality, Minas Gerais State, Brazil. F: stations at Frutal watershed; B: stations at Bebedouro watershed; R1: degraded headwater; R2: preserved headwater; ETE: sewage treatment plant of Frutal city. Source: modified from Menezes (2011).

All stations also measured water temperature, $\mathrm{pH}$, electrical conductivity, dissolved oxygen concentration, total dissolved solids, turbidity with a Hanna HI9828 multi-analyzer. Water samples were collected to determine total alkalinity, chlorophyll-a, total phosphorus and total nitrogen, and were analyzed in laboratory according to the Standard Methods of Water and Wastewater (APHA et al., 2012).

As the water column was shallow, sediment samples were collected by means of a manual sampler corer, Kajac type. Samples were stored in plastic bags and refrigerated until analysis to preserve their organic matter content. According to Santos et al. (2013), all particulated mineral materials were considered for granulometric composition: individual 
mineral grains, rock fragments not modified or partially modified, concretions, nodules, and similar materials cemented.

Sediment samples from each station ( $c a .100 \mathrm{~g}$ ) were dried at $40^{\circ} \mathrm{C}$ for 48 hours (Almeida et al., 2012). Dry material was smoothly macerated in a mortar to break down the aggregates contained in the sediment. The samples were then sieved through a sieve shaker for 30 minutes. The resulting fractions in each sieve were weighed to calculate the percentage. The grain classification followed the Wentworth Scale (Table 1), as proposed by Suguio (1973). For graphs and statistical analyses, the size classes were regrouped according to the ABNT scale (ABNT, 1995), considering three classes: silt/clay $(<0.06 \mathrm{~mm})$, sand $(0.06 \mathrm{a}$ $2.00 \mathrm{~mm})$ and gravel/pebble $(>2.0-60<\mathrm{mm})$.

For organic matter content, sediment samples were dried at $60^{\circ} \mathrm{C}$ for 24 hours, and after that weighed to obtain weight 1 (total dry weight). The samples were then calcinated in a muffle at $460^{\circ} \mathrm{C}$ for 2 hours to obtain weight 2 (inorganic matter). Organic matter content was calculated by the difference between weights 1 and 2, according to Bicudo and Bicudo (2004).

Table 1. Sieve size, Wentworth scale for granulometric composition and correspondence to NBR 6502 (ABNT, 1995).

\begin{tabular}{cclc}
\hline Sieve size $(\mathrm{mm})$ & Phi scale & Classification & NBR 6502/1995 \\
\hline 2 & -1 & Very coarse sand & Sand \\
1 & 0 & Coarse sand & \\
0.5 & 1 & Medium sand & \\
0.25 & 2 & Fine sand & \\
0.125 & 3 & Very fine sand & \\
0.063 & 4 & Silt & Silt/Clay \\
\hline
\end{tabular}

The minerals present in sediments were identified by X-ray diffraction (XRD), and nine representative stations were selected: R1, R2, F3, F12, F13 (Frutal Watershed), and B1, B5, B6, B7 (Bebedouro Watershed). A diffractometer (PANalytical / X`Pert Pro) was used, with $\mathrm{CoK} \alpha$ radiation in the range between 4 and $50^{\circ} 2 \theta$, at intervals from $0.017^{\circ} 2 \theta$ to $1 \mathrm{step} \mathrm{s}^{-1}$, at a $40 \mathrm{kV}$ voltage and $30 \mathrm{~mA}$ current. The interpretation of XRD data was based on Bish and Post (1989).

Differences between watersheds and seasons for sediment samples were tested by analysis of variance (ANOVA). To assess the impact of silting of the two watersheds on the quality of water, a principal component analysis (PCA) was performed considering the fractions of sieves and physical and chemical parameters. Variables with a low range of variation or redundancy in the data were not employed in the PCA.

\section{RESULTS AND DISCUSSION}

During the sampling, the first visual observation in the field reveals that both watersheds have several points of soil loss associated with various uses, especially intensive agriculture (sugar cane) and extensive cattle ranching, culminating in accelerated erosion (laminar mainly) and silting of stream channels.

Mean water temperatures were $26.2^{\circ} \mathrm{C}$ and $27.1^{\circ} \mathrm{C}$, between the dry and rainy seasons, respectively. These data prove that the seasonality of the region is characterized by rainfall, not by temperature range (summer/winter). The $\mathrm{pH}$ values were near neutrality varying between 6.42 and 7.43. Electrical conductivity values exceeded the water quality standard 
$\left(100 \mu \mathrm{S} \mathrm{cm}^{-1}\right)$ in stations at Frutal Stream that suffer direct impacts of farming (R1), of the sewage treatment plant (F5, F6, F8, F10, F12) and of the urban area (F15, F16, F17). In these stations, dissolved oxygen concentrations were under the water quality standard of $5 \mathrm{mg} \mathrm{L}^{-1}$ (CONAMA, 2005).

Mean values of total dissolved solids were higher during the rainy season $\left(54.2 \mathrm{mg} \mathrm{L}^{-1}\right)$ due to the higher loading of flash floods in relation to the dry season $\left(48.1 \mathrm{mg} \mathrm{L}^{-1}\right)$. Higher values of turbidity (30.13 NTU) and total alkalinity $\left(130.1 \mathrm{mg} \mathrm{L}^{-1} \mathrm{CaCO}_{3}\right)$ were observed in stations impacted by the sewage treatment plant (F5 and F6), but did not exceed the water quality standard of $100 \mathrm{NTU}$ and $500 \mathrm{mg} \mathrm{L}^{-1} \mathrm{CaCO}_{3}$, respectively. Contrasting, chlorophyll- $a$, total phosphorus and nitrogen standards of $30 \mu \mathrm{g} \mathrm{L}^{-1} ; 0.100 \mathrm{mg} \mathrm{L}^{-1}$ and $2.18 \mathrm{mg} \mathrm{L}^{-1}$ (CONAMA, 2005) were exceeded at these two stations. Higher values were observed on Station F5 in the dry season, when chlorophyll- $a$ reached $124.3 \mu \mathrm{g} \mathrm{L}^{-1}$, total phosphorus: $0.116 \mathrm{mg} \mathrm{L}^{-1}$ and total nitrogen: $6.46 \mathrm{mg} \mathrm{L}^{-1}$. Total nitrogen standards also were exceeded in Stations F6 (5.68 $\left.\mathrm{mg} \mathrm{L}^{-1}\right), \mathrm{F} 15\left(2.63 \mathrm{mg} \mathrm{L}^{-1}\right)$ and F16 (4.24 $\left.\mathrm{mg} \mathrm{L}^{-1}\right)$ in the same season.

Granulometric composition of samples collected in Frutal Stream (Figure 2) showed the predominant fractions in sediments are related to sieves $2,0.25$ and $0.125 \mathrm{~mm}$ (very coarse sand, fine sand and very fine sand, respectively). The high amount observed in the mesh of 2 $\mathrm{mm}$ is probably overestimated for the formation of stable aggregates in the soil, with difficult dispersion, while smaller meshes, as described above, confirm the higher concentration of sand in the surrounding soils, especially Rhodic Ferralsols (FR), which produced sediments that reflect its texture (mean) and morphological conditions observed at field. Comparing the dry and rainy seasons, no significant difference was observed $(F=1.644 ; p=0.208)$.

Regrouping the fractions in three classes (Figure 2), in general, an increase in the proportion of sand $(0.05$ to $2.00 \mathrm{~mm})$ was observed in the rainy season, in contrast to very fine particles (silt/clay) or very coarse particles (gravels/pebbles). In most of the stations and seasons, the sand fraction represented more than $50 \%$ of sediments, reaching $99.6 \%$.

As an exception, the fraction gravel/pebble showed its higher percentages at Stations F14 (68.3\%) and F16 (52.10\%) in the dry season, and at Stations F15 (67.1\%) and F7 (61.6\%) in the rainy season. These stations belonging to the Vertente Grande Stream (completely located in the urban area) and the Marianinho Stream (Station F7, a tributary of the Frutal Stream), which are impacted by the disposal of waste construction. The fraction silt/clay showed higher percentages only in Stations F5 (35.5\%) and F6 (24.4\%), downstream to effluent discharges from sewage treatment plant.

Granulometric fractions of Bebedouro Stream are presented in Figure 3, which shows the same pattern of concentration of grains as samples in Frutal Stream. The high amount of grains retained in sieves of 2, 0.25 and $0.125 \mathrm{~mm}$, especially in last two meshes, indicates the texture and morphology of Rhodic Ferralsols FR predominating in the region, originated from clastic sedimentary rocks.

Regrouping the fractions of different sieves of sediments from Bebedouro Stream into three classes, the same pattern was observed as of Frutal Stream with a predominance of sand $(0.05$ a $2.00 \mathrm{~mm})$. There is a slight increase of finest fractions (silt/clay), during rainy season, in stations downstream, especially in B8 (7.9\%) and $\mathrm{J}(12.2 \%)$, due to higher turbidity and very fine suspended particles, that naturally happens in precipitation periods. However, Figure 3 shows a static structure of textural distribution, without significant difference between seasons $(\mathrm{F}=0.597 ; \mathrm{p}=0.453)$ when compared to Figure 2. The fraction gravel/pebble was predominant only at Station B2 in the dry $(53.9 \%)$ and rainy seasons (59.1\%); this is a headwater stretch, slightly impacted and with preserved riparian vegetation. Comparing both watersheds, there was no significant difference between sediment fractions $(\mathrm{F}=2.566 ; \mathrm{p}=0.115)$. 


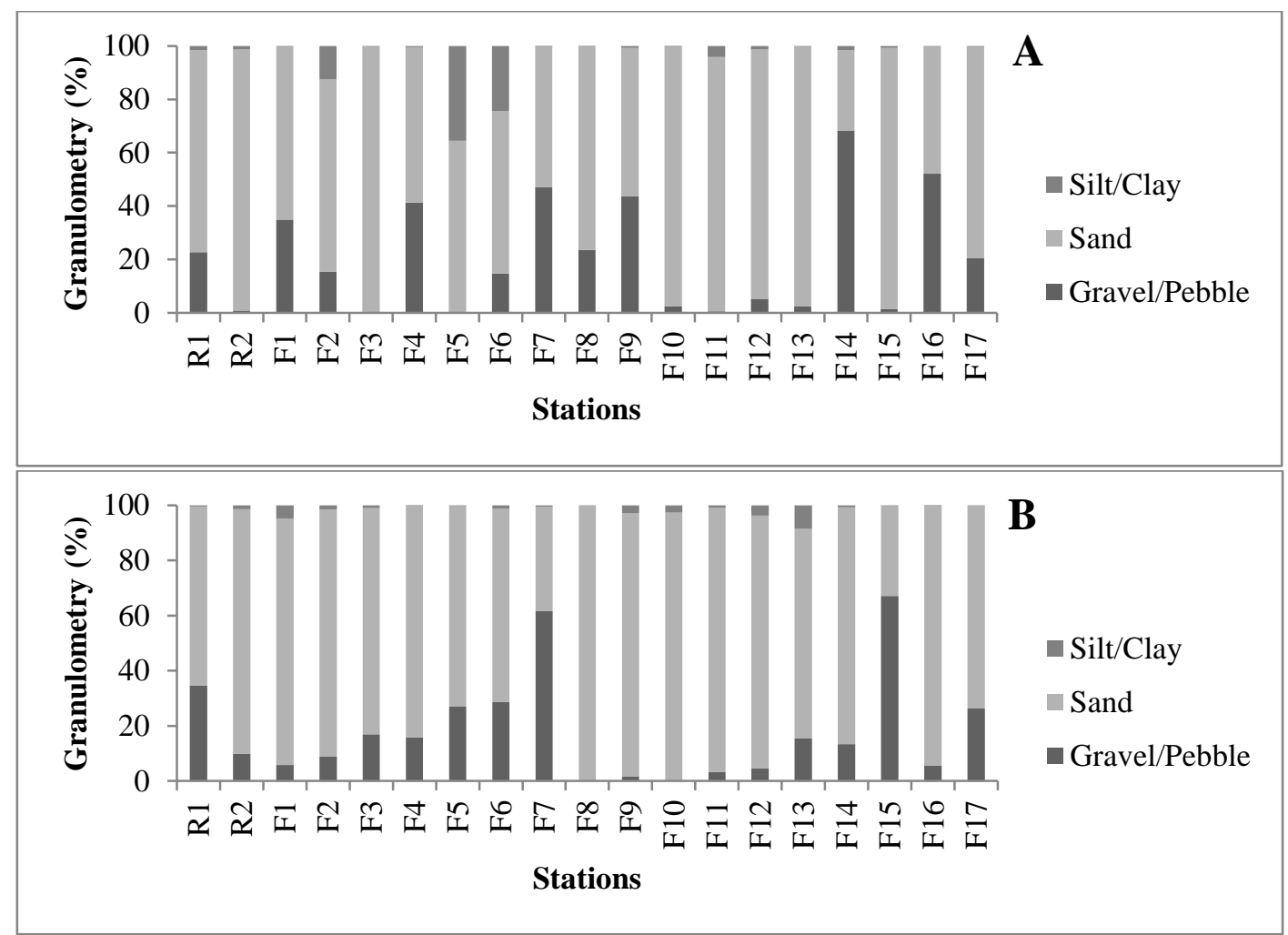

Figure 2. Granulometric composition of Frutal Stream in the dry season - A (Set/2012), and the rainy season - B (Mar/2013), according to ABNT scale (ABNT, 1995).

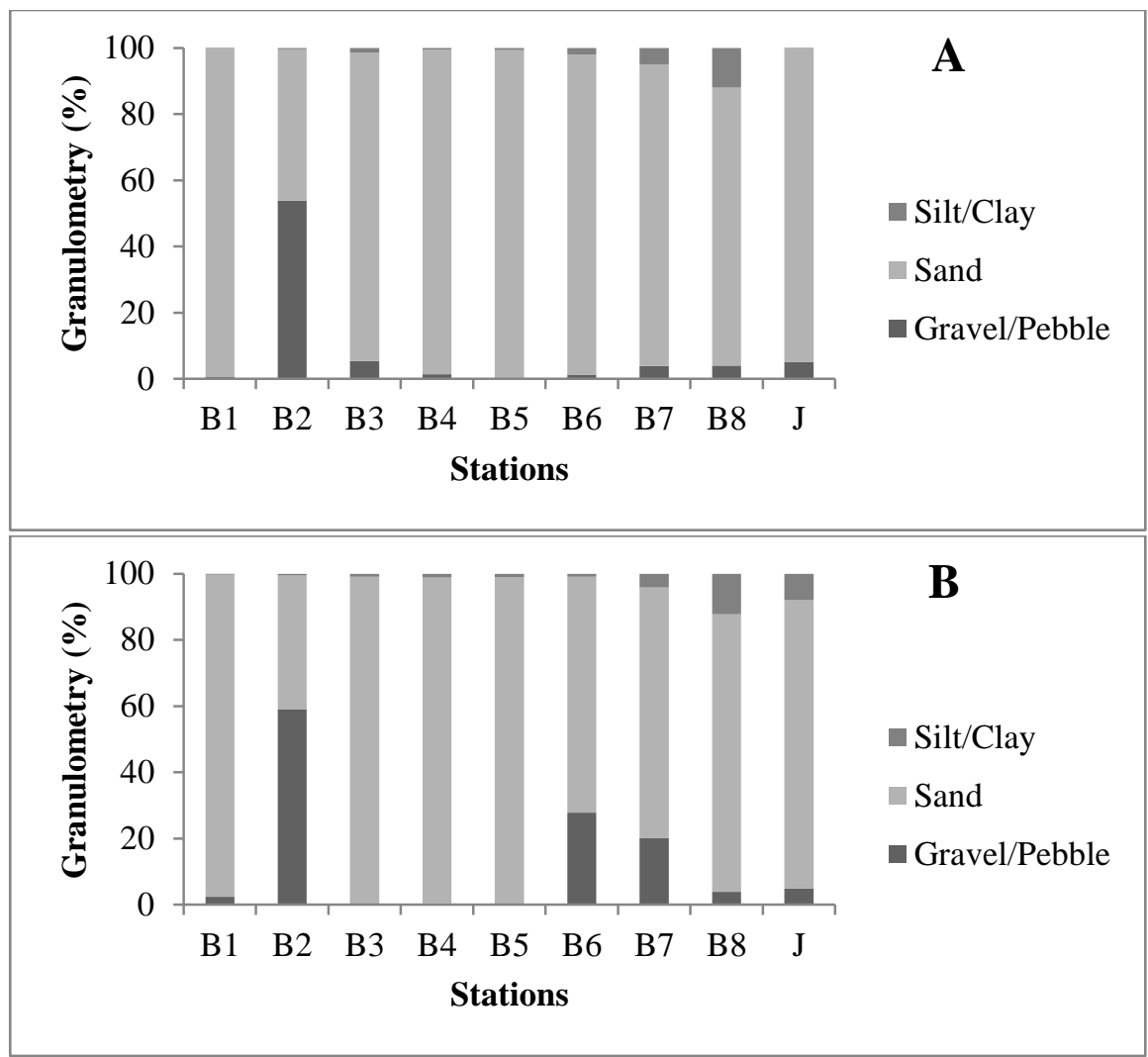

Figure 3. Granulometric composition of Bebedouro Stream in the dry season - A (Set/2012), and the rainy season - B (Mar/2013), according to ABNT scale (ABNT, 1995). 
Percentages of organic matter content are shown in Figure 4. As expected, there was a predominance of inorganic material, associated with the higher amount of sand in the samples. As expected for upstream stretches, Station R1 had higher fractions of gravel/pebble; but because it is a degraded headwater, the erosive processes are reflected in the low organic matter content. On the other hand, Station R2, being a headwater with preserved riparian vegetation, shows higher values of organic matter due to the contribution of allochthonous litter.

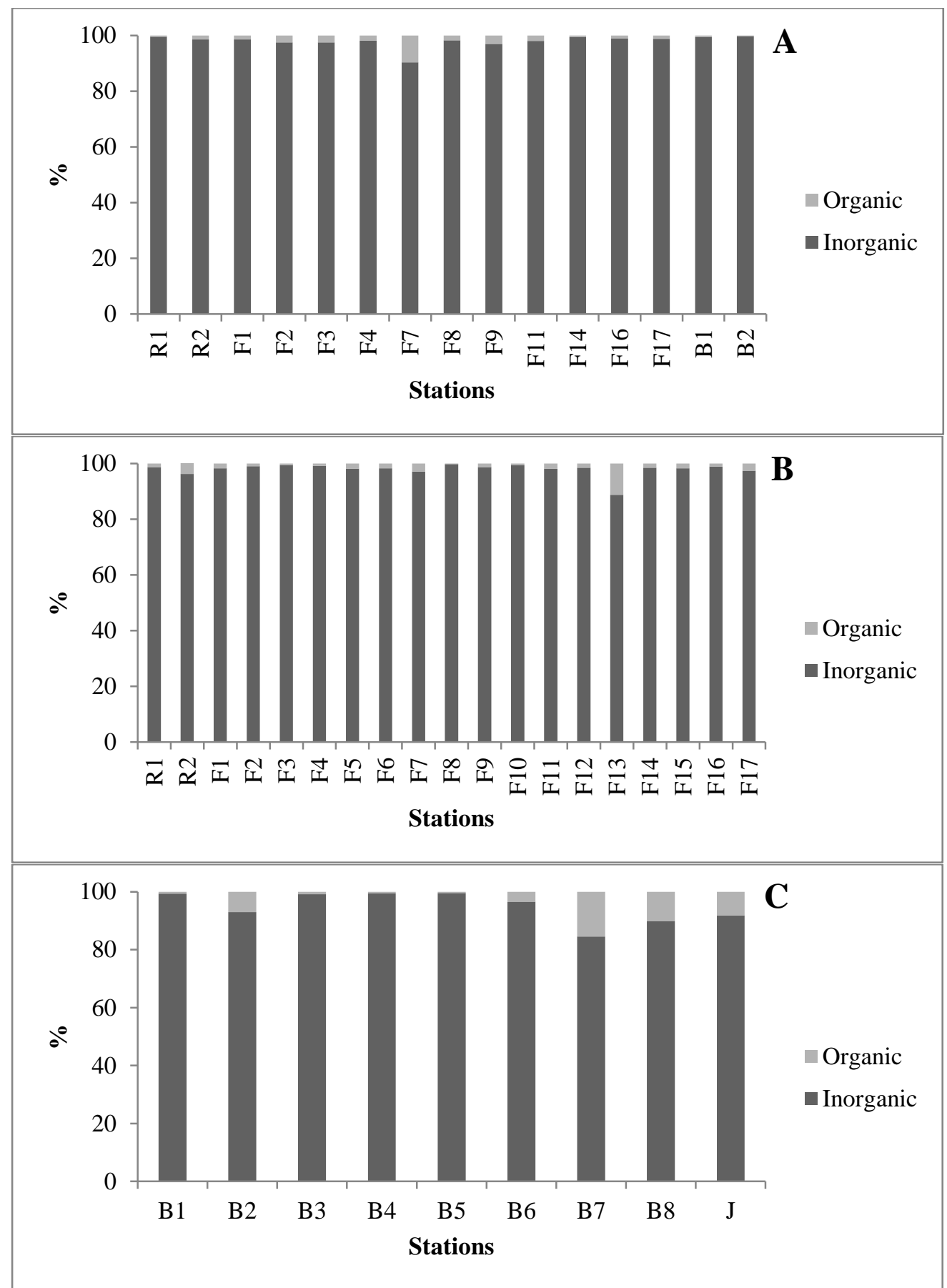

Figure 4. Organic matter content of Frutal and Bebedouro Streams in the dry season - A (Set/2012), and the rainy season - B and C (Mar/2013). In A, the presentation of only a few stations of both watersheds is due to loss of samples. 
XRD results of sediments from Frutal and Bebedouro Stream are found in Figures 5 and 6. In most stations only quartz was observed as a mineral component.
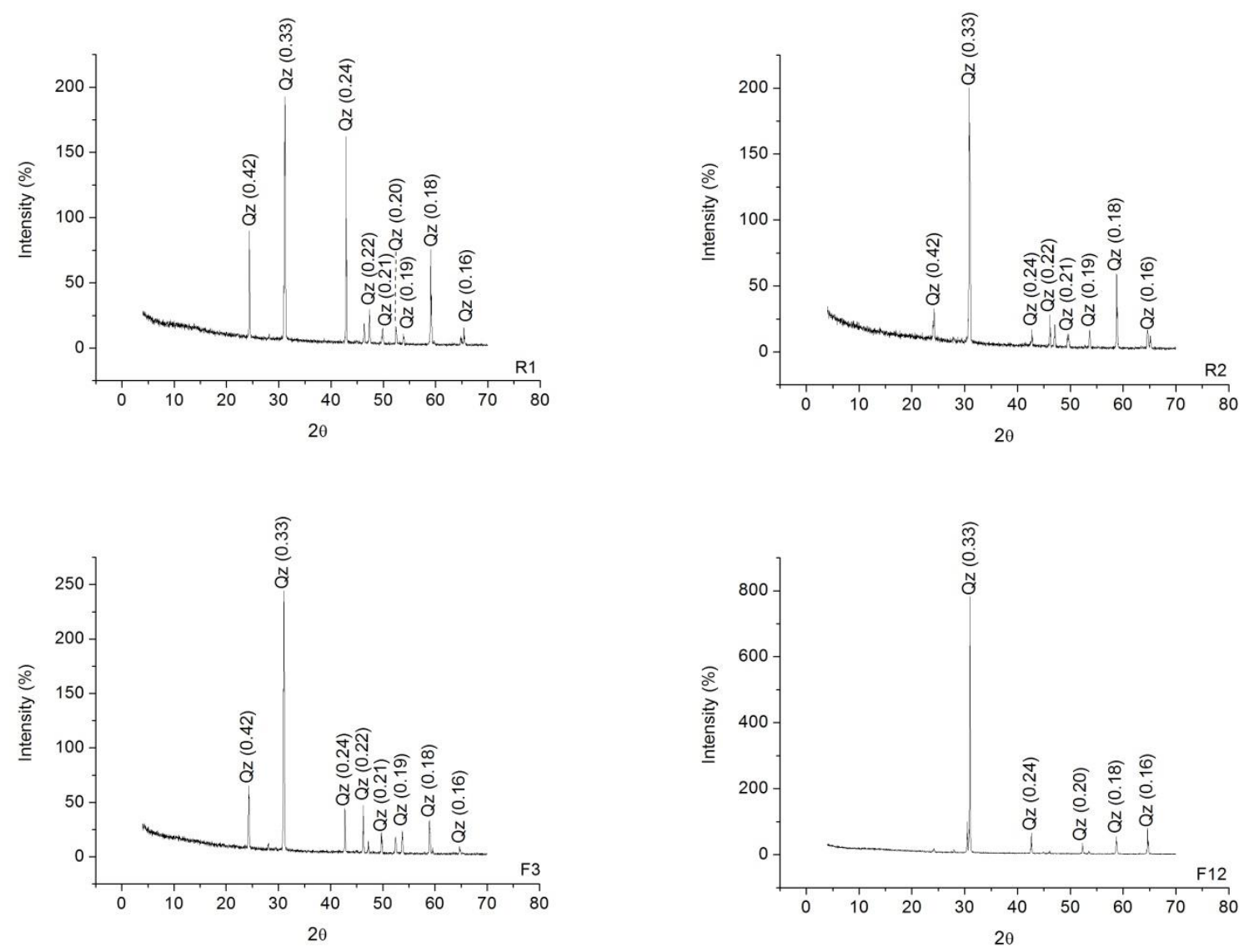

Figure 5. XRD results of stations R1, R2, F3, F12 - Frutal Stream. Spacing “d” in nm. Qz - quartz.

For stations $\mathrm{F} 13$ and $\mathrm{B} 7$, clay minerals kaolinite $\left(\mathrm{Al}_{2} \mathrm{Si}_{2} \mathrm{O}_{5}\left(\mathrm{OH}_{4}\right)\right)$, gibbsite $\left(\mathrm{Al}_{2} \mathrm{O}_{3}\right)$, anatase $\left(\mathrm{TiO}_{2}\right)$ and hematite $\left(\mathrm{Fe}_{2} \mathrm{O}_{3}\right)$ (Figure 7) were found in the sediments observed. Station $\mathrm{F} 13$, because it is further downstream, receives all the sediment loads of the watershed of Frutal Stream. This explains the detection of oxides, which are clay minerals, which may be free or forming stable micro-aggregates.

Figure 2-B shows a certain proportion of silt/clay in rainy season, whose minerals were consequently detected in X-ray diffraction. At Station B7, clay minerals were also detected in the sediments. This station is located in a further tributary of Bebedouro Stream, highly silted due to the complete removal of its riparian vegetation, which also brought sediments, subsequently collected and analyzed by XRD.

Principal component analysis (Table 2, Figure 8) showed in first factor (45.9\%) a strong correlation among silt/clay fractions and physical and chemical water quality parameters: electrical conductivity, total dissolved solids, total alkalinity, chlorophyll- $a$ and total phosphorus and nitrogen. In the second factor (18.3\%), the separation between stations where predominate sand and those ones with the presence of gravel/pebble was clear. The total percentage of explanation is $64.2 \%$. In Figure 8, it is also possible to verify a weak but significant correlation (coefficient below 0.70) between altitude and gravel/pebble; this fraction was higher in some stations upstream on both watersheds (especially R1 and B2). 

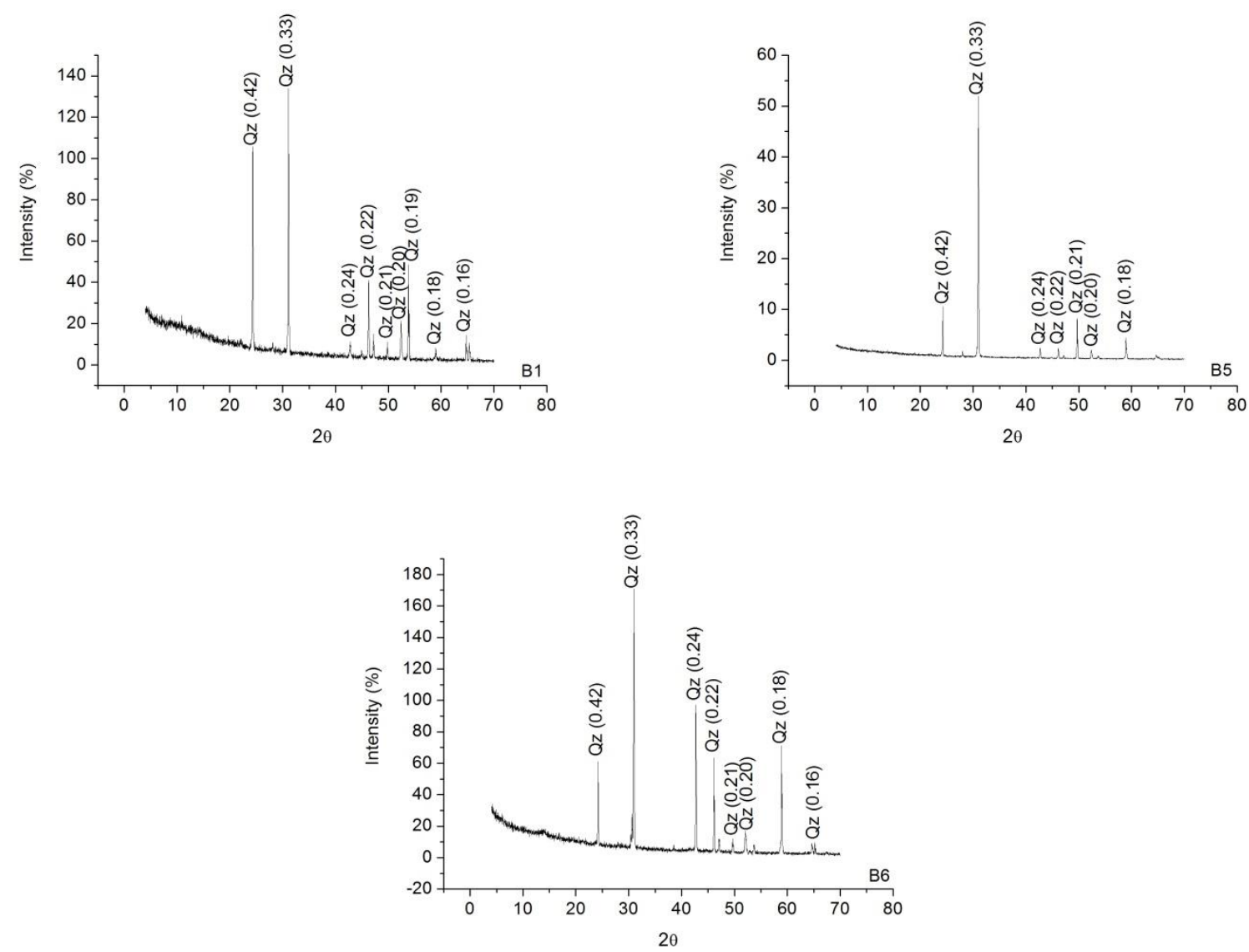

Figure 6. XRD results of stations B1, B5, B6 - Bebedouro Stream. Spacing “d” in nm. Qz - quartz.
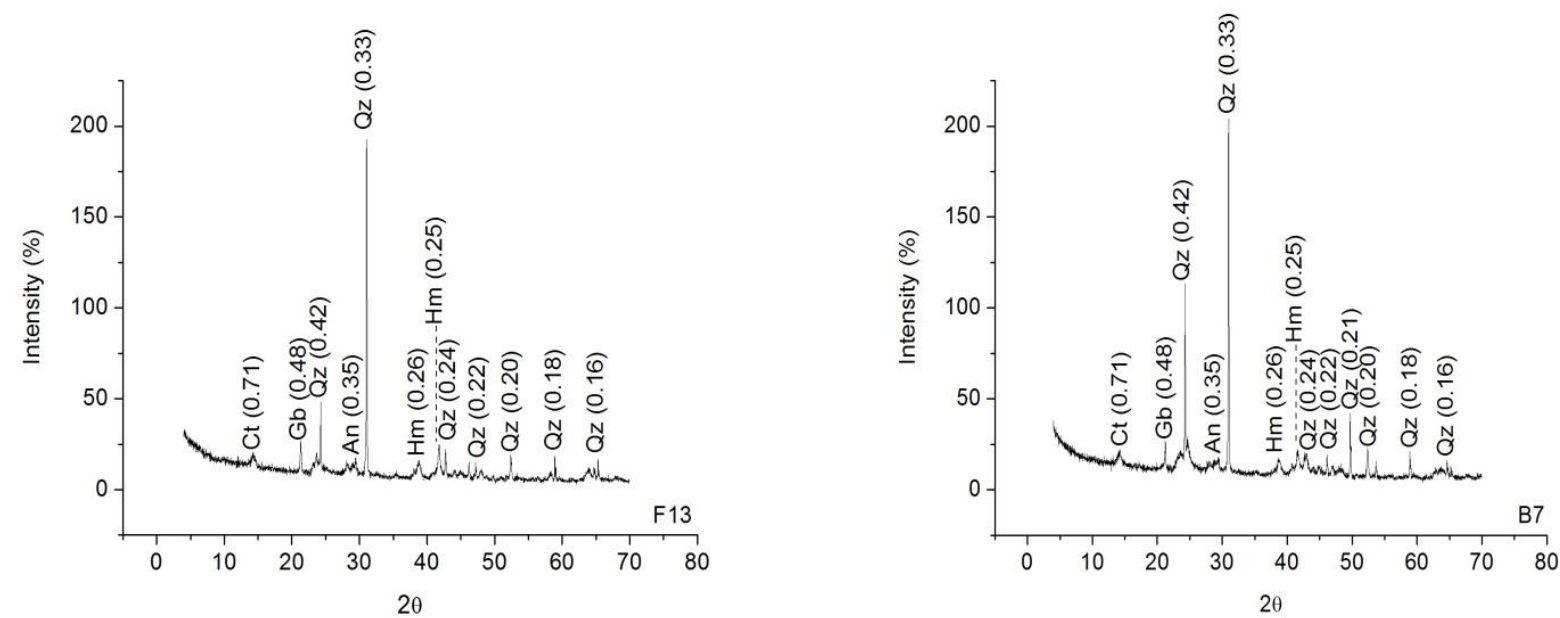

Figure 7. XRD results of Station F13 (left) and B7 (right) - Frutal Stream. Spacing "d" in nm. Qz: quartz, Ct: kaolinite, Gb: gibbsite, An: anatase, Hm: hematite. 
Table 2. Principal component analysis for granulometric composition of sediments and physical and chemical water parameters of Frutal and Bebedouro Streams (Frutal, MG). Values in bold represent significant correlations with factors $(\mathrm{p}<0.05)$.

\begin{tabular}{lll}
\hline Variable & Factor 1 & Factor 2 \\
\hline Gravel/Pebble & 0.0542 & $\mathbf{- 0 . 8 9 6 3}$ \\
Sand & 0.1948 & $\mathbf{0 . 8 6 1 2}$ \\
Silt/Clay & $\mathbf{- 0 . 7 8 8 3}$ & 0.1445 \\
Altitude & 0.1446 & $\mathbf{- 0 . 6 3 3 7}$ \\
Dissolved Oxygen & 0.6411 & -0.0276 \\
Electrical Conductivity & $\mathbf{- 0 . 8 4 1 1}$ & -0.1092 \\
Total Dissolved Solids & $\mathbf{- 0 . 8 1 6 6}$ & -0.1083 \\
Temperature & -0.3286 & 0.5667 \\
Turbidity & -0.6668 & 0.1442 \\
Total Alkalinity & $\mathbf{- 0 . 8 2 1 0}$ & -0.1843 \\
Chlorophyll- $a$ & $\mathbf{- 0 . 8 0 5 5}$ & 0.0274 \\
Total Phosphorus & $\mathbf{- 0 . 9 6 4 9}$ & 0.0052 \\
Total Nitrogen & $\mathbf{- 0 . 8 3 1 5}$ & -0.0986 \\
\hline
\end{tabular}

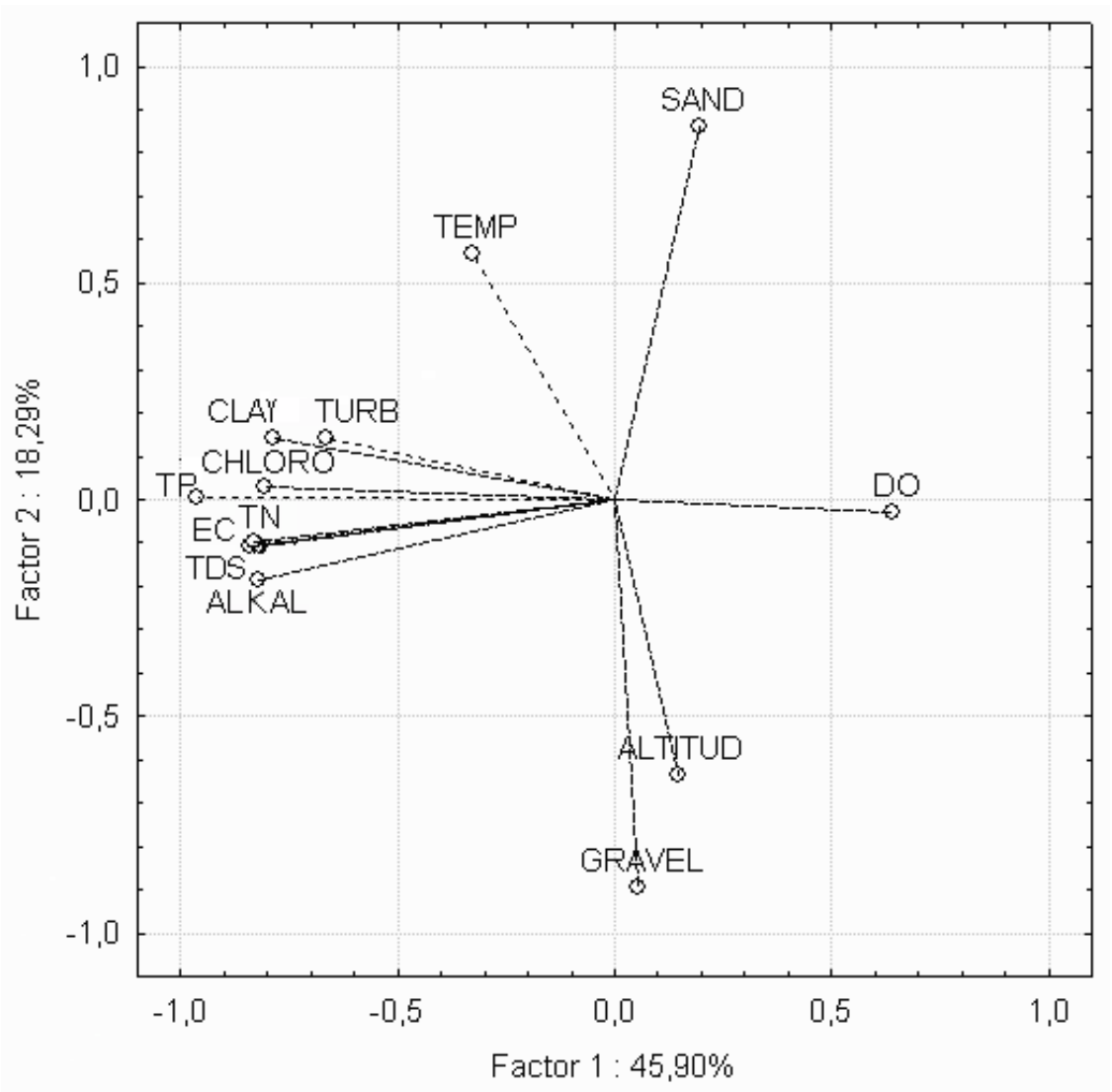

Figure 8. Principal component analysis for granulometric composition of sediments and physical and chemical water parameters of Frutal and Bebedouro Streams (Frutal, MG). 
The increasing in the sand fraction during the rainy period, even while not significant, evidences the process of leaching to which both watersheds are submitted. Quartz is the predominant mineral in sediments due to the fact that the soils of the region are formed (broadly) from sandstone, and because they are highly weathered; basically this primary mineral in the coarse fraction of soil (or on this study case, sediment) remained. Within the sequence weathering, this mineral is the most resistant to chemical change in environmental systems. At the same time, it reveals little nutritional reserves of the sediments studied. The clays detected could be from the processing of minerals from both the Vale do Rio do Peixe Formation (environmental dominance) and basalts of the Serra Geral Formation.

According to Kämpf et al. (2012), the mineralogy of Ferralsols predicts the occurrence of kaolinite, iron and aluminum oxides, with minor proportions of other components in the clay fraction. The possibility of occurrence, at some points, of outcrop/weathering basalts of the Serra Geral Formation, which is stratigraphically below the sandstones of the Vale do Rio do Peixe Formation, contributes to the occurrence of clay minerals that appeared in X-ray diffractograms.

It is remarkable that the highest proportion fraction $>2 \mathrm{~mm}$ found in the Frutal watershed (especially in the Vertente Grande Stream) is associated with increased of anthropogenic changes and the production of rubble. That is, the supply of gravel/pebble diagnosed is not only due to the mineral fragments and rocks of the region. Bebedouro Stream, comparatively, is in better conservation status once completely inserted in the rural area, with larger riparian vegetation on its margins and without urbanization as in Frutal watershed.

There are more than 100 meters of difference between the headwaters of the Frutal Stream and its confluence into the Grande River. The higher inclination, located especially in upstream stretch, characterizes the watershed as ecologically fragile, where runoff, coupled with intensive agriculture, has higher potential energy that disaggregates the exposed soil and transports sediments to adjacent water bodies (Merten and Minella, 2002).

An important fact should be noted in Stations B3, B4, B5 and B6 in the Bebedouro Stream and F10 in the Frutal Stream. At these stations, there are basaltic outcrops, forming rapid stretches, providing oxygenation of the water and improvement in its quality. For this reason, they should be analyzed with reservations, as the sand predominance does not reflect the true conditions of these stations, which also show well-preserved riparian vegetation, being also tourist attractions in the region.

The transport and deposition of sediments occur continuously in the studied watersheds, consequently influencing the operation of water systems. Pesticides can be transported by being adsorbed into inorganic or organic particles in the sediments. In this way, studies of sedimentation are very relevant currently, informing the strategic planning of budgets for the rational management of soil and water (Merten and Minella, 2002).

Silted material is one of the main transporters of nutrients and pollutants, contributing to the eutrophication/contamination of aquatic environments (Santos, 2002). Among the inorganic components, clays have a significant ion exchange capacity and transport chemical compounds adsorbed in them (Payne, 2006). This relationship was evidenced by principal component analysis, where water quality variables showed higher values correlated to the presence of the fraction silt/clay and/or organic matter content in the sediment samples, especially in Stations F5, F6, F13, B7, B8 and J. In samples F13 and B7, especially, clay minerals $1: 1$ and $\mathrm{Fe}, \mathrm{Al}$, and $\mathrm{Ti}$ oxides were detected in the $\mathrm{X}$-ray results that can explain the highest sorption capacity of the sediment on the mentioned stations.

Higher results of electrical conductivity can be due to a higher concentration of divalent cations in sediments, probably coming from overestimated fertilization in the areas of cultivation in both watersheds, as this is a common practice in areas of intensive agriculture. Less soluble salts, in this case, $\mathrm{Ca}^{2+}$ and $\mathrm{Mg}^{2+}$, evidenced by total alkalinity, and large 
amounts of total phosphorus and heavy metals (deriving from pesticides, mainly) may be adsorbed in iron oxides $\left(\mathrm{Fe}^{3+}\right)$, which when reaching the water bodies, are reduced $\left(\mathrm{Fe}^{2+}\right)$ releasing these pollutants ions. So, in the areas of slopes and hill tops, adsorbed ions remain neutralized and stable, but when they reach the water channels, they are released, and may pollute the aquatic environment.

Studies by Barreto et al. (2007) indicate that sediments are the final destination of trace metals. When compared with other environmental compartments (water and air), they constitute compartment of highest concentration of metals. According to the authors, one of the important factors controlling the adsorption and retention of metals in sediment is the particle size, it being recognized that most of the heavy metals are bound to the fine fraction of sediments $(<0.002 \mathrm{~mm})$, mainly due to higher surface area and humic substances content. Therefore, there is an inverse correlation between the particle size and concentration of metals in sediment.

Even in the middle and lower stretches of both watersheds, with good agricultural potential, excessive soil disturbance and insufficient reposition of organic matter favor physical deterioration, and also causes increased runoff and contamination of surface water with sediment, nutrients, animal waste and pesticides that are adsorbed by clays (Merten and Minella, 2002).

Lemes et al. (2003), assessing sediments of water supply stations from the Rivers Pardo and Mogi-Guaçu (Northeast of São Paulo State), found higher values of iron and manganese in areas with lower vegetative cover (compared with other areas with higher vegetative cover) indicating metal inputs from rocks where the soil degradation was intense, allowing the release of these minerals. They also observed higher phosphorous concentrations in stations near urban areas. Comparing two preserved headwaters and two under the influence of sugar cane crops, Donadio et al. (2005) also found significant differences in temperature, color, turbidity, alkalinity and total nitrogen, with higher values in those with vegetation exploited by agriculture.

Regarding the organic matter content, Stations B8, F13 and J have higher percentages probably related to the influence of the Marimbondo Reservoir. Due to longer residence time, there is the accumulation of fine sediment that contains a higher percentage of organic matter compared to those stations located in lotic stretches of the two watersheds. On the other hand, the higher percentages of organic matter in Stations F7 and B7, are caused by underground sewage discharges in the urban perimeter of Frutal Stream and the advanced state of silting due to complete suppression of riparian vegetation, respectively. These are among the most impacted in the two watersheds.

Considering the rainy season, the Bebedouro Stream has more organic matter than the Frutal Stream. The increased production of biomass, the entrance of allochthonous material and the better conservation status of riparian vegetation and soils probably explains this.

As with the clays, organic matter has a decisive role in the ion exchange of soil, adsorbing several nutrients and pollutants, coming from application of inputs in agricultural areas. Furthermore, it is important for water retention in the soil and for its structure (formation of organo-mineral complexes), besides being a source of nutrients for microorganisms.

Once sand was the dominant fraction in the sediment (due, mainly, to the medium texture of Rhodic Ferralsols formed by weathering from sandstones of Vale do Rio do Peixe Formation); it is possible to infer that agricultural activity is the potential cause of accelerated erosion and silting of the two watersheds.

If the erosion and silting processes continue at this rate in watershed of the Frutal Stream, the estimated scenario with its respective population projection and hydric demands suggests that in two decades the water catchment will not be enough to supply the city, according to a 
report from the Water Supply Company of Minas Gerais State - COPASA (Sepúlveda, 2009).

\section{CONCLUSIONS}

Agricultural activity can be considered the main cause of accelerated erosion and silting of the two watersheds. Quartz is the predominant mineral in studied sediments due to the fact that the soils of the region are formed largely from sandstones, indicating, consequently, little nutritional reserves in the materials studied. Outcrop/weathering of basalts from Serra Geral Formation, which is stratigraphically below the sandstones of Vale do Rio do Peixe Formation, contributes to the occurrence of clay minerals found in X-ray diffraction (XRD).

The Bebedouro Stream shows a better conservation status once it is completely inserted in a rural area, with larger riparian vegetation and without urbanization as is the case of the Frutal Watershed. Principal component analysis revealed that water quality variables showed high correlation values with the silt/clay fraction and/or organic matter in the sediment samples. Physical deterioration of soils causes increased runoff and contamination of surface water with sediment, nutrients, animal waste and pesticides that are adsorbed by clays.

\section{ACKNOWLEDGEMENTS}

To the Project TCT 17049/2011 - SECTES/FAPEMIG/HIDROEX - Diagnosis of Watersheds for Sustainability that financed this research and PIBIC/UEMG/FAPEMIG for the undergraduate grants (Process number 07/2011 and 06/2012).

\section{REFERENCES}

ASSOCIAÇÃO BRASILEIRA DE NORMAS TÉCNICAS - ABNT. NBR 6502: rochas e solos. Rio de Janeiro, 1995.

AMERICAN PUBLIC HEALTH ASSOCIATION - APHA; AMERICAN WATER WORKS ASSOCIATION - AWWA, WATER ENVIRONMENT FEDERATION - WEF. Standard Methods for examination of water and wastewater. 22nd ed. Washington, DC, 2012. 1360 p.

ALMEIDA, B. G.; DONAGEMMA, G. K.; RUIZ, H. A.; BRAIDA, J. A.; VIANA, J. H. M.; REICHERT, J. M. M. et al. Padronização de métodos para análise granulométrica no brasil. Comunicado Técnico ${ }^{\circ}{ }^{6}$ 66. Rio de Janeiro: Embrapa, 2012. 11 p.

BARRETO, M. S.; ALVES, J. P. H.; PASSOS, E. A.; GARCIA, C. A. B. Distribuição de metais pesados na fração fina $(<63 \mu \mathrm{m})$ dos sedimentos superficiais da sub-bacia hidrográfica do rio Poxim - SE. São Paulo: Sociedade Brasileira de Química, 2007. $175 \mathrm{p}$.

BICUDO, D. C.; BICUDO, C. E. M. Amostragem em limnologia. São Carlos: Rima, 2004. $372 \mathrm{p}$.

BISH, D. L.; POST, J. E. Modern powder diffraction. Reviews in Mineralogy, 20. Washington, DC: Mineralogical Society of America, 1989. 369 p.

CARDOSO, A. A. G. Diagnóstico e Implantação de Práticas Conservacionistas na SubBacia do Córrego Frutal, Frutal (MG). 2008. 42 f. Monografia (Especialização em Gestão e Manejo Ambiental em Sistemas Agrícolas) - Universidade Federal de Lavras, Lavras, 2008. 
CONSELHO NACIONAL DO MEIO AMBIENTE - CONAMA (Brasil). Resolução $n^{\circ} 357$, de 17 de março de 2005. Classificação dos corpos de água e diretrizes ambientais para o seu enquadramento, bem como estabelece as condições e padrões de lançamento de efluentes. Diário Oficial [da] União, Brasília, v. 53, p. 58-63, 18 mar. 2005.

COMPANHIA DE PESQUISA DE RECURSOS MINERAIS - CPRM; SERVIÇO GEOLÓGICO E MINERALÓGICO DO BRASIL - SGMB. Mapa geológico do estado de Minas Gerais. Brasília, DF, 2003. Escala de 1:1.000.000.

CUNHA, N. R. S.; LIMA, J. E.; GOMES, M. F. M.; BRAGA, M. J. A intensidade da exploração agropecuária como indicador da degradação ambiental na região dos Cerrados, Brasil. Economia e Sociologia Rural, v. 46, n. 2, p. 291-323, 2008. http://dx.doi.org/10.1590/S0103-20032008000200002

DONADIO, N. M. M.; GALBIATTI, J.A.; PAULA, R.C. 2005. Qualidade da água de nascentes com diferentes usos do solo na bacia hidrográfica do Córrego Rico, São Paulo, Brasil. Engenharia Agrícola, v. 25, n. 1, p. 115-125, 2005. http://dx.doi.org/10.1590/S0100-69162005000100013

ESTEVES, F. A. Fundamentos de limnologia. 3. ed. Rio de Janeiro: Interciência, 2011. 826 p.

FERREIRA, D. J. F. Dinâmica de transporte de sedimento em dois sistemas lóticos da cidade de Frutal - MG. 2005. 31 f. Monografia (Geografia) - Universidade do Estado de Minas Gerais, Frutal, 2005.

INSTITUTO BRASILEIRO DE GEOGRAFIA E ESTATÍSTICA - IBGE. Cidades. 2014. Available in: http://www.cidades.ibge.gov.br/xtras/home.php. Access in: May 2016.

KÄMPF, N.; MARQUES, J. J.; CURI, N. Mineralogia de solos brasileiros. In: KER, J. C.; CURI, N.; SCHAEFER, C. E.; TORRADO, P. V. Pedologia: fundamentos. Viçosa: SBCS, 2012. p. 81-146.

KLINK, C. A.; MACHADO, R. B. Conservation of the Brazilian Cerrado. Conservation Biology, v. 19, p. 707-713, 2005. http://dx.doi.org/10.1111/j.1523-1739.2005.00702.x

LAL, R. Soil degradation by erosion. Land Degradation and Development, v. 12, n. 6, p. 519-539, 2001.

LEMES, M. J. M; FIGUEIREDO-FILHO, P. M.; PIRES, M. A. F. Influência da mineralogia dos sedimentos das bacias hidrográficas dos rios mogi-guaçu e pardo na composição química das águas de abastecimento público. Química Nova, v. 26, n. 1, p. 13-20, 2003. http://dx.doi.org/10.1590/S0100-40422003000100004

MENEZES, E. Mapa da área aproximada das bacias do ribeirão Frutal e Córrego Bebedouro. Frutal: Topogeo, 2011. Escala 1:30.000.

MERTEN, G. H.; MINELLA, J. P. Qualidade da água em bacias hidrográficas rurais: um desafio atual para a sobrevivência futura. Agroecologia e Desenvolvimento Rural Sustentável, v. 3, n. 4, p. 33-38, 2002.

MORGAN, R. P. C. Soil erosion and conservation. $3^{\text {rd }}$ ed. Hoboken: Wiley-Blackwell, 2005. 304p.

PAYNE, A. I. The ecology of tropical lakes and rivers. New York: John Wiley \& Sons, 2006. 
SANTOS, J. A. G. Poluição do solo e da água. In: ARAÚJO, Q. R. 500 anos de uso do solo no Brasil. Ilhéus: Editus, 2002. p. 239-246.

SANTOS, R. D.; LEMOS, R. C.; SANTOS, H. G.; KER, J. C.; ANJOS, L. H. C.; SHIMIZU, S. H. Manual de descrição e coleta de solo no campo. 5. ed. Viçosa: SBCS, 2013. 100 p.

SOUZA, A. N. Diagnóstico da situação do córrego Vertente Grande, município de Frutal, MG. 2009. 37 f. Monografia (Graduação em Geografia) - Universidade do Estado de Minas Gerais, Frutal, 2009.

SUGUIO, K. Introdução à sedimentologia. São Paulo: Edgard Blucher, 1973. 317p.

SEPÚLVEDA, W. O. Relatório de definição de fonte de produção. Frutal: COPASA, 2009. $14 \mathrm{p}$.

VARANDA, L. Avaliação do projeto CENEP - COPASA 2004 a 2006. Frutal: COPASA, 2007. $11 \mathrm{p}$. 


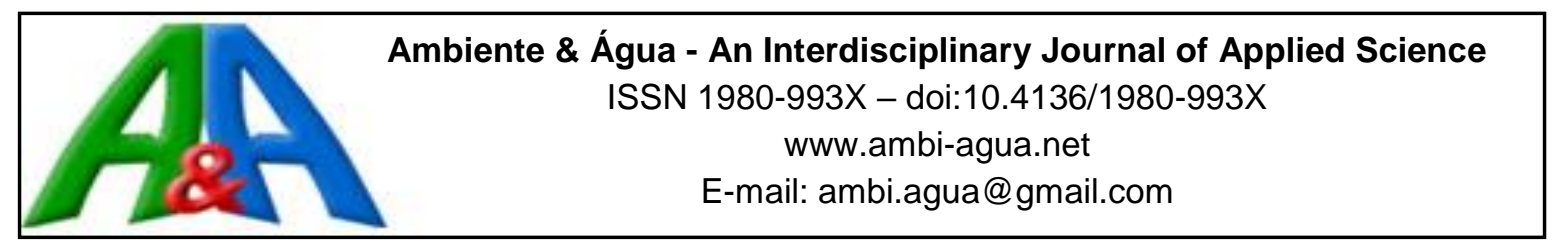

\title{
Water management assessment methodology for urban planning
}

\author{
doi:10.4136/ambi-agua.1917
}

Received: 11 Apr. 2016; Accepted: 24 Nov. 2016

\author{
Giovana Ulian ${ }^{1 *}$; Ivan Cartes ${ }^{1}$; Maria Manuela C. Lemos Lima ${ }^{2}$ \\ ${ }^{1}$ Universidad del Bío-Bío (UBB), Concepción, Chile \\ Departamento Planificación y Diseño Urbano \\ ${ }^{2}$ Universidade do Minho (UM), Campus de Azurém, Guimarães, Portugal \\ Departamento de Engenharia Civil. \\ "Corresponding author: e-mail: giovana.ulian@terra.com.br, \\ cartes@ubiobio.cl,mmlima@civil.uminho.pt
}

\begin{abstract}
One of the biggest challenges in urban planning is to balance the use of natural resources with the need to preserve them. One of the main resources is water, which is essential to human life and activities. Population growth and urban sprawl challenge water availability. Thus, it is important to evaluate development trends in order to predict future scenarios, enabling the adoption of preventive actions and decision-making. The objective of this study is to present a water management assessment methodology for urban planning as a practical and direct tool capable of conveying the necessary information for decision making in the process of balanced and harmonious urban planning, applicable to medium size Brazilian cities.
\end{abstract}

Keywords: evaluation indicators, urban expansion, urban policy.

\section{Metodologia de avaliação da gestão da água para o planejamento urbano}

\section{RESUMO}

Um dos grandes desafios aos planejadores do espaço urbano está em conciliar o uso dos recursos naturais com a necessidade de preservá-los. Neste sentido a água, enquanto recurso natural prioritário, fundamenta a existência e promove as atividades humanas. $\mathrm{O}$ crescimento populacional e a expansão urbana desafiam a disponibilidade de água. Desta forma é essencial diagnosticar os impactos do desenvolvimento para prognosticar cenários futuros, possibilitando nortear ações preventivas e a tomada de decisão. O objetivo deste estudo é apresentar uma metodologia de avaliação diagnóstica para a gestão da água como ferramenta prática e direta que permite auxiliar no levantamento de informações necessárias para o planejamento urbano equilibrado e harmônico, aplicável a cidades brasileiras de porte médio.

Palavras-chave: abastecimento de água, crescimento urbano, indicadores de avaliação. 


\section{INTRODUCTION}

Spatial sustainability is advocated by some urban planners, who believe that compact cities with higher population concentrations facilitate mobility through a more efficient transport system. On another hand, some environment scientists counter that sustainability is achieved by greener, more conservative, self-supplying cities, with smaller population density. As a way to find a solution to this impasse, Agudelo-Vera et al. (2011) state that sustainable urban development should promote the management of scarce resources integrated with urban planning.

It is imperative that more information is developed regarding the environment, especially concerning the hydrologic impacts driven by land-use changes (Tong et al., 2009). The sudden transformation of rural areas into urban areas demands the adoption of strategies that consider the conservation of water resources, and allow changes in a sustainable way.

Despite having a close connection with urban design and land use and occupation, sanitation in Brazil tends merely to meet emerging demands, and does not contribute to the organization of urban space. These sanitation actions are carried out in a non-integrated way, as an answer to immediate problems rather than considering preventive planning or needed improvements (Bernardes et al., 2006). According to Andrade and Blumenschein (2014), research concerning the urban water cycle within a river basin should be linked to studies of urban ecosystems and the constructed environment, considering the spatial organization of the community and landscape patterns. In conventional urban design, urban, hydrologic and environmental concepts are not articulated or considered during town planning processes.

Water flows, considered by Pickett et al. (2013) to be a significant dimension to connect ecology, urban design and social background, have an important role to play in urban systems or "urban ecosystems". Urban sprawl damages water systems and causes drastic changes in hydrologic regimes. In Brazilian municipalities, it is usual to increase water availability without considering strategies that improve water management and could reduce water demand.

There are limits to water availability. The negative impacts associated with the increase of water withdrawal rates for human consumption and the pollution of water bodies must be addressed; it is therefore imperative to adopt planned management of water demand (Thompson, 1999).

"Ecological Urbanism" considers that cities need to adapt to changing human needs, and that water is an important variable to be considered in urban planning (Whiston and Spirn, 2013). The use of multiple limits, such as river basins, parceling, dwellings and natural areas within the urban matrix, emphasizes the ecology capacity to connect the system structure, the management of human choices, design, political interventions, and their consequences to ecological functioning (Pickett et al., 2013).

The use of indicators is considered a fundamental strategy to identify and qualify important aspects of urban inter-relations. Indicators are indexes that can determine changes and the state of a phenomenon, making it possible to monitor its evolution. According to Dos Santos (2004), an indicator can determine the degree of changes and the conditions in the environment and, if well conducted, allows the representation of the causes that exist in a particular environment. Rodríguez et al. (2015) state that the development of indicators concerning the integration of water issues and urban planning will help to quantify their interaction, generating a significant improvement in the application of the Water Sensitive Urban Design (WSUD) concept, and might support mitigating inappropriate planning consequences. WSUD methodology proposed to the city of Melbourne by Barton and Argue (2007) aimed to avoid, or at least minimize, the environmental impact of pollution to a water body caused by building. 
Currently, references concerning the integration of water management as a tool for urban planning are rare according to Dickie et al. (2010), even though it is an appropriate methodology for urban planning.

The project "WATER in CORE" is a pilot-project for river basin water management in the Mediterranean, based in five river basins in Greece, Italy, Spain and Cyprus. This study aims to integrate the principles of Local Agenda 21 with water resources management, resulting in twenty-nine indicators, focused on water preservation and avoidance of water stress. Indicators describe the performance and are categorized as environmental, social and developmental (WaterInCore, 2012).

Castro (2007) gave a questionnaire to representatives of public agencies, water resources managers and researchers so that they attributed weights to the indicators that he had defined. His objective was to propose a methodology for the evaluation of urbanization's effects on water bodies, which could support the managers' decisions regarding the granting of authorizations for construction and water use. He sought to evaluate the most relevant effects of urbanization on water bodies, through the use of multi-criteria analysis methods.

The system SNIS (of the original Portuguese designation: Sistema Nacional de Informações sobre Saneamento, Sanitation National System of Information) has indicators that are used to diagnose water and wastewater public services in Brazilian municipalities and is used as the official sanitation database. These indicators aim to compare performance among municipalities and to facilitate the regulation of services and to improve their management (SNIS, 2010).

Based on these studies, this article presents a methodology to evaluate cities' expansion based on the management of human consumption of water, structured on twenty-six indicators, designated by "Hydricity" indicators. The name Hydricity was created to identify the set of indicators developed in this research, which include water resources, cities, and sustainability concepts. Therefore, hydricity is blend of the words for hydri - referring to water, ci - referring to cities and ty - referring to sustainability (Ulian, 2015).

Monitoring using indicators provides assessment of the current situation and allows one to project trends over time, providing permanent responses to governments and citizens. According to Rodríguez et al. (2015) indicators can be useful to predict future scenarios and guide preventive actions. Despite the apparent popularity of the use of indicators based on the concept of sustainable development, their definition is still very generic and has given rise to multiple interpretations, provoking an explosion of indicator types (Tanguay et al., 2010).

This methodology was developed to assist in the diagnosis of cities development from a water resources point of view, with the objective of rendering operational actions for urban planning. The option for the anthropocentric variables adopted in this article resulted from the fact that the present approach is necessarily focused on the use of water as a resource, which supports the life of the inhabitants of urban areas.

It is important to recognize that the development and the selection of indicators are reflexive and subjective processes (Grunwald, 2004), and this work falls within this concept.

This study focused on medium-sized Brazilian cities, due to their considerable number of inhabitants, the regional importance they play, and the lack of research concerning cities this size as well.

\section{MATERIAL AND METHODS}

This article is part of a broader study, which was carried out in three stages: a) "Hydricity" indicators definition, b) benchmarking definition and c) proposal of an integrated method of the first two stages. Based on Ulian (2015) and Ulian et al. (2015a), who presented the first two stages, the main objective of this paper is the development of an assessment 
methodology through the integration of "Hydricity" indicators. This integration consists of transforming a dimensional value of a qualitative or quantitative indicator into a non-dimensional parameter, allowing the results to be interpreted in a qualitative way and facilitating comparisons. In addition, the integration of indicators is conducted in order to allow analysis as a group of indicators (sectorial) and also globally.

During stage a) indicators definition, care was taken to limit the number of indicators so that the list was sufficiently broad and covered the parameters and criteria previously established. The conceptual cut-off for the definition and choice of indicators was based on the criteria of urban morphology, environmental support capacity and efficiency in water systems. The selected indicators are presented in Table 1 .

Table 1. "Hydricity" indicators and their selection sources.

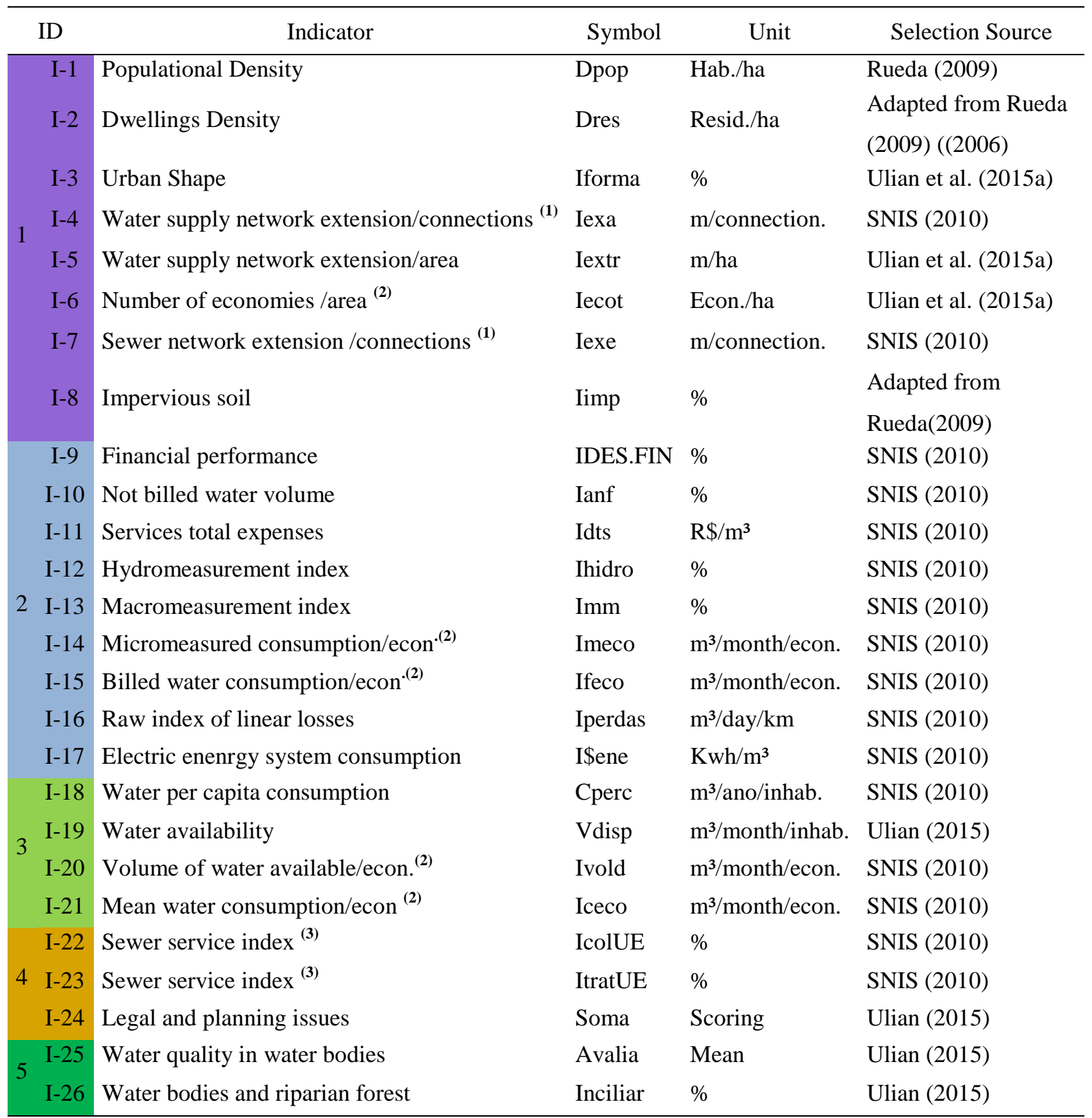

Note: ${ }^{(1)}$ - Network connections: Referring to the number of connections between the main water network and the plot where the building is located. A plot of a multi-family building has only one connection of water or sewage. ${ }^{(2)}$ - Economies referring to all units of land use. Example: a residence, a business, an industry, each one represents an economy. ${ }^{(3)}$ - Indicator I22 refers to sewer drainage and I23 to wastewater treatment. 
Some indicators were created to meet the established criteria. The twenty-six "Hydricity" indicators also went through the analysis of water management and urban planning experts to be validated. Seeking to facilitate the organization and to present the indicators in a sectorial way, they were divided into five groups: Group 1 - Urban Efficiency, comprises indicators related to the use and occupation of land, the shape of the city and the associated water infrastructure; Group 2 - Operational Management of the water supply system, relates to physical and financial control of the water system, from abstraction to distribution; Group 3 Availability versus Consumption, presents aspects related to the availability of water in the territory of the municipality and its relation to demand; Group 4 - Sewage and Legal, is constituted by indicators regarding management of sanitary sewage and the qualitative indicators referring to the legal and technical regulations that the municipality should implement to regulate the urban expansion; Group 5 - Support Capacity, represents the indicators that evaluate the environmental conditions faced with city growth.

To comply with stage c), integration of the "Hydricity" indicators and to enable a diagnostic analysis, it was necessary to comply with stage b) benchmarking definition, i.e. benchmarks that make it possible to compare the results of the calculated indicators. These benchmarks, also called benchmarking literature, were defined as the best and conventional practices benchmarks (Mateus and Bragança, 2009). Benchmarking is presented in Table 2.

Table 2. Adopted Values for best and conventional practices.

\begin{tabular}{|c|c|c|c|c|}
\hline ID & Best Practice & References & $\begin{array}{l}\text { Conventional } \\
\text { Practice }\end{array}$ & References \\
\hline $\mathrm{I}-1$ & 135 & Rueda (2009) & 43 & Cities group $^{(\mathbf{I})}$ \\
\hline $\mathrm{I}-2$ & 85 & Rueda (2009) & 14 & Cities group ${ }^{(\mathbf{1})}$ \\
\hline $\mathrm{I}-3$ & 70 & Vitoria Gasteiz (2014) ${ }^{(2)}$ & 37 & Cities group ${ }^{(\mathbf{1})}$ \\
\hline $\mathrm{I}-4$ & 9.4 & Hypothetical model city ${ }^{(3)}$ & 20.5 & SNIS (2010) \\
\hline $\mathrm{I}-5$ & 158.7 & Hypothetical model city ${ }^{(3)}$ & 139.7 & Cities group ${ }^{(\mathbf{1})}$ \\
\hline I-6 & 51.6 & Hypothetical model city ${ }^{(3)}$ & 17.2 & Cities group ${ }^{(\mathbf{1})}$ \\
\hline $\mathrm{I}-7$ & 9.4 & Hypothetical model city ${ }^{(3)}$ & 15.4 & SNIS (2010) \\
\hline $\mathrm{I}-8$ & 70 & Rueda (2009) & 50 & Brazilian legislation mean ${ }^{(5)}$ \\
\hline $\mathrm{I}-9$ & 97.0 & Vitoria Gasteiz (2014) ${ }^{(2)}$ & 67.8 & SNIS (2010) \\
\hline $\mathrm{I}-10$ & 15.8 & Vitoria Gasteiz (2014) ${ }^{(2)}$ & 27.2 & SNIS (2010) \\
\hline $\mathrm{I}-11$ & 0.06 & SNIS (2010) & 1.04 & SNIS (2010) \\
\hline $\mathrm{I}-12$ & 100 & Maximum value & 86.1 & SNIS (2010) \\
\hline $\mathrm{I}-13$ & 100 & Maximum value & 20 & Assigned value ${ }^{(6)}$ \\
\hline $\mathrm{I}-14$ & 5.3 & Zaragoza (2011) ${ }^{(\mathbf{4})}$ & 16.2 & SNIS (2010) \\
\hline $\mathrm{I}-15$ & 121.0 & Vitoria Gasteiz (2014) ${ }^{(2)}$ & 18.1 & SNIS (2010) \\
\hline $\mathrm{I}-16$ & 1.1 & Vitoria Gasteiz (2014) ${ }^{(2)}$ & 21.8 & SNIS (2010) \\
\hline $\mathrm{I}-17$ & 0.1 & SNIS (2010) & 0.69 & SNIS (2010) \\
\hline $\mathrm{I}-18$ & 40 & UN (1992) & 70 & Rueda (2009) \\
\hline $\mathrm{I}-19$ & 208.2 & ABNT-NBR 12.211(1992) and 2.218 (1994) & 219 & SNIS (2010) \\
\hline $\mathrm{I}-20$ & 93.9 & SNIS (2010) & 24.3 & SNIS (2010) \\
\hline $\mathrm{I}-21$ & 53.0 & Zaragoza (2011) ${ }^{(\mathbf{4})}$ & 40.1 & SNIS (2010) \\
\hline $\mathrm{I}-22$ & 100 & Maximum value & 79 & SNIS (2010) \\
\hline $\mathrm{I}-23$ & 100 & Maximum value & 20 & SNIS (2010) \\
\hline $\mathrm{I}-24$ & 25 & Assigned value ${ }^{(6)}$ & 5 & Assigned value ${ }^{(6)}$ \\
\hline $\mathrm{I}-25$ & Good to excellent & Assigned value ${ }^{(6)}$ & Bad & Assigned value ${ }^{(6)}$ \\
\hline $\mathrm{I}-26$ & 18 & Vitoria Gasteiz (2014) ${ }^{(2)}$ & 30 & CONAMA (2006) \\
\hline
\end{tabular}

Note: ${ }^{(1)}$ - Cities group: referential obtained from the average of medium-sized cities: Piracicaba-SP, Uberlândia-MG, Sorocaba-SP and Juiz de Fora-MG, which stood out in the Sanitation Ranking of the Trata Brasil Institute (2010); ${ }^{(2)}-$ Vitória Gasteiz: calculated values for the city of Vitoria Gasteiz - Spain, considered to be referential for good practices in water management; ${ }^{(3)}$ - Hyphotectical model city: for this indicator, a hypothetical city model was created in order to define best practices; ${ }^{(4)}$ - Zaragoza: calculated values for the city of Zaragoza, Spain, considered to be referential for good practices in water management; ${ }^{(5)}$ - Brazilian legislation mean: several municipal planning legislation was studied and an average value was adopted as referential; ${ }^{(6)}$ - Assigned value: value attributed by the authors based on their work experience. 
Best practice is understood as the referential model, which can be taken as a goal to be achieved. For the best practice referential definition, indicators of cities with recognized performance in sustainable urban management and focus on the preservation of water resources were selected. Some indicators best practices were also selected from the SNIS database (SNIS, 2010). When it was not possible to obtain these references in medium-sized cities, data from cities in other countries were used.

The conventional practice was considered as the minimum value that an indicator should achieve. If the value achieved is below the conventional practice threshold, the city is considered as not concerned with sustainability, especially considering the given indicator. This standard should correspond to the minimum values that regulations, norms and laws should contain.

Once the referential values were established, the following stage was calculated for the city under evaluation. After calculating these indicators, a methodology was necessary to evaluate the values achieved and to integrate the "Hydricity" indicators.

The indicators of Group 1 (Urban Efficiency) are analyzed irrespective of the other groups, using an abacus. This differentiation was made to allow the analysis of the municipality urban efficiency independently of the other indicators. Three abacuses with four axes are drawn, being each half axis representative of an indicator. For benchmarking, an abacus should be designed for best practice values, another with the values of conventional practice and a third abacus with the values of the indicators calculated for the city under evaluation. All abacuses should be drawn using the same scale. The resulting shapes should be compared to evaluate to which shape the cities performance is most similar with, best or conventional practices. Other forms of interpretation could be used, such as overlapping the shapes of the three abacuses. Figure 1 exemplifies a case study carried out in the city of Caxias do Sul, presented in Ulian et al. (2015b).

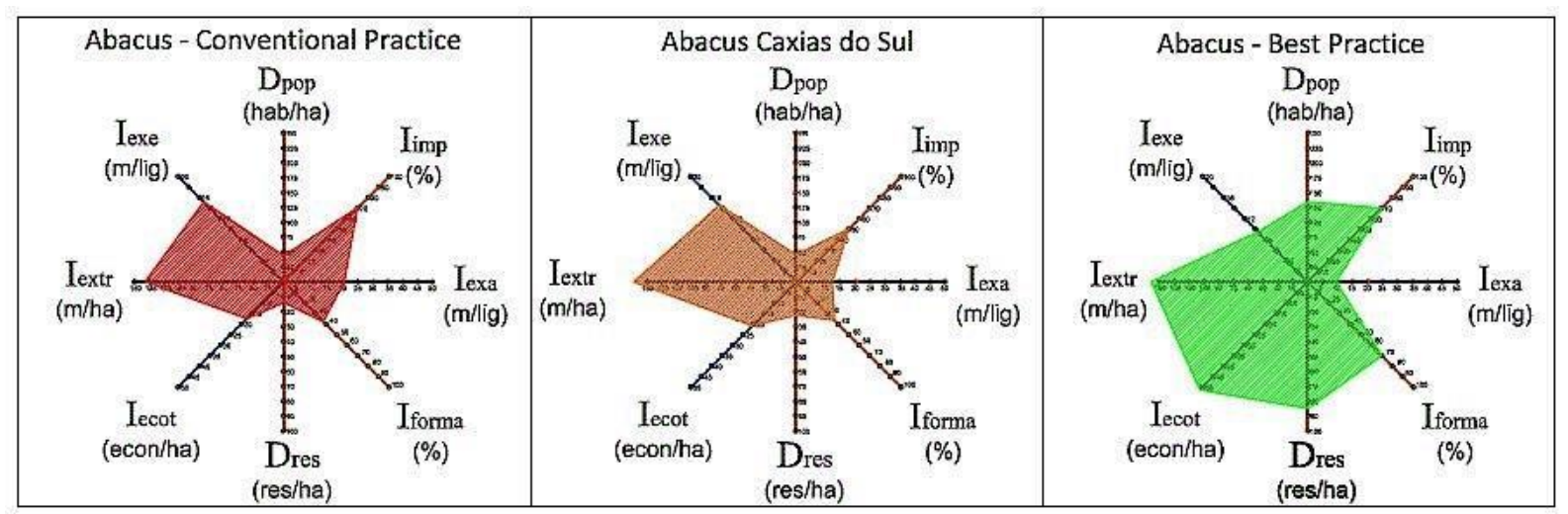

Figure 1. Group 1 application of indicators using comparative abacuses.

Source: Ulian et al. (2015b).

The other indicators, related to Groups 2, 3, 4 and 5, are grouped through normalization of the values and application of a weighting system in two moments. In the first moment, the aggregation of the indicators at a sectorial level is achieved in this way obtaining results for each group. The second weighting is carried out to enable the aggregation of the four groups in a single score. The aggregation process is based on the SBTool ${ }^{\mathrm{PT}}$ methodology (Mateus and Bragança, 2009). Figure 2 presents a schematic description of the evaluation process.

The evaluation process for the indicators of Groups 2, 3, 4 and 5 is divided into three phases:

- Phase 1: Performance quantification at indicator level: allows isolated analyses; 
- Phase 2: Performance quantification at group level: allows sectorial analysis; and

- Phase 3: Quantification of "Hydricity" Global Level: allows global analysis.

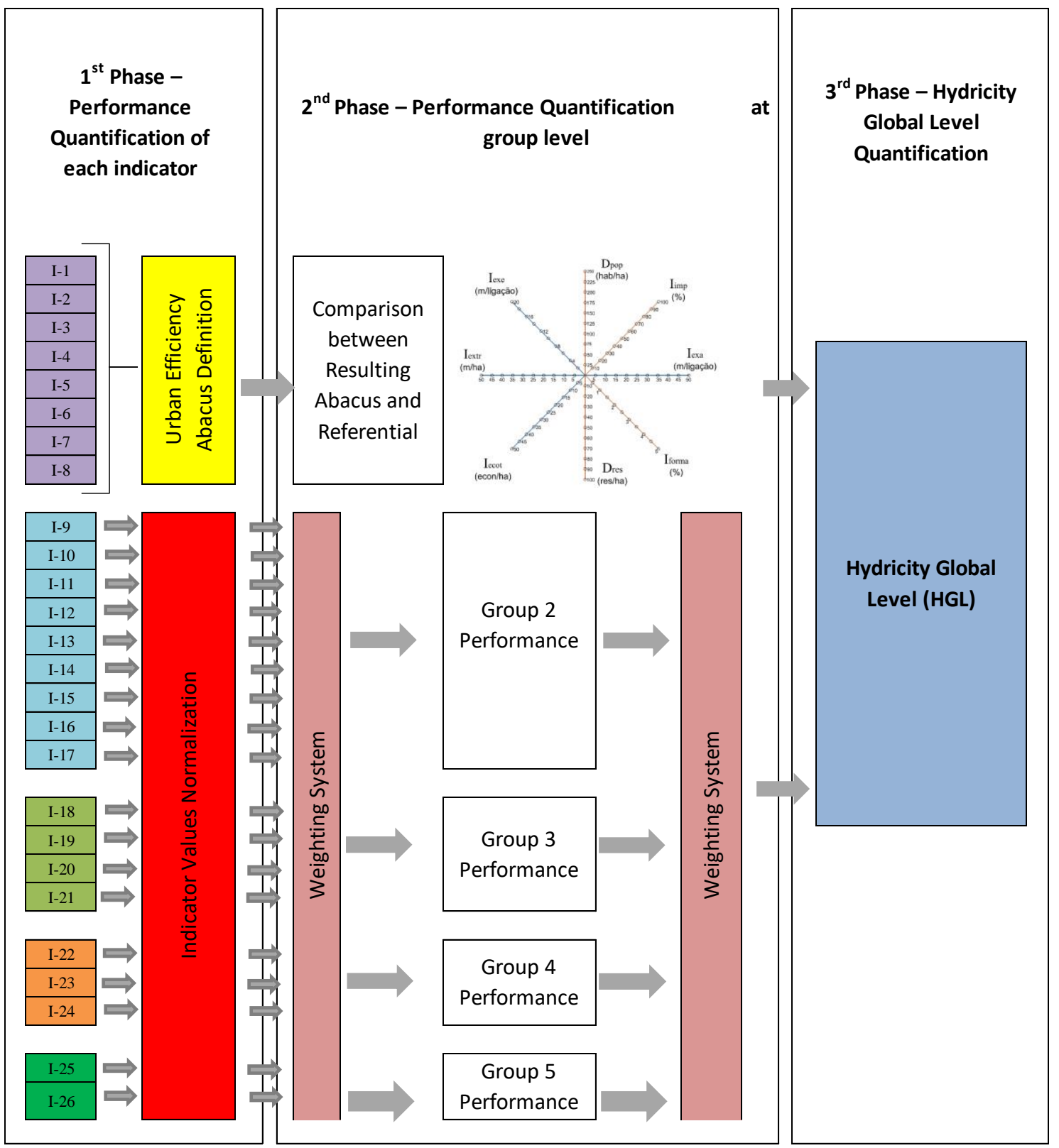

Figure 2. Summary of the proposed method.

The performance evaluation at the level of each indicator corresponds to the quantification of the parameters and the normalization, as described:

a) Quantification of Parameters: the method used to quantify each indicator, i.e. application of the calculation process and definition of best and conventional practice referential. The equations for the quantification of each indicator were presented in Ulian (2015);

b) Normalization: it aims to establish a dimensionless value that expresses the performance of each indicator concerning the referential presented. The weighting systems assigned to normalization were presented in Ulian (2015), see Table 5. From the normalization, it is possible to have an isolated evaluation for each indicator. The 
Diaz-Balteiro Equation 1 was used in the normalization process (Mateus and Bragança, 2009).

$$
\overline{\mathrm{P}}_{\mathrm{i}}=\frac{\mathrm{P}_{\mathrm{i}}-\mathrm{P} *_{\mathrm{i}}}{P i^{*}-\mathrm{P} *_{\mathrm{i}}} \forall_{\mathrm{i}}
$$

where:

$\overline{\mathrm{P}}_{\mathrm{i}}$ is normalization result of parameter $\mathrm{i}, \mathrm{Pi}$ is the quantification value, and

$\mathrm{Pi}^{*}$ and $\mathrm{P} * \mathrm{i}$ are the benchmarks of the parameter $\mathrm{i}$, representing the levels of best and conventional practices, respectively.

The use of Equation 1 allows converting parameters' values on a dimensionless scale, where the value 0 (zero) corresponds to the conventional practice and the value 1 to the best practice level. If the indicator value is greater than the best practice, or smaller than that of conventional practice, the parameter's normalized value assumes a value greater than 1 and smaller than 0, respectively. In any case, to avoid distortions in the aggregation of the indicators/groups, the normalized values to be considered cannot be smaller than -0.2 and greater than 1.2, as recommended by Mateus and Bragança (2009).

Table 3 presents the equivalence used in the conversion of the normalized value.

Table 3. Equivalence used in the conversion of the normalized value.

\begin{tabular}{cc}
\hline $\begin{array}{c}\text { Qualitative } \\
\text { scale }\end{array}$ & Normalized value \\
\hline A $^{*}$ & $\overline{\mathrm{P}}>1.00$ \\
$\mathrm{~A}$ & $0.70 \overline{<\mathrm{P}} \leq 1.00$ \\
$\mathrm{~B}$ & $0.40 \overline{<\mathrm{P}} \leq 0.70$ \\
$\mathrm{C}$ & $0.10 \overline{<\mathrm{P}} \leq 0.40$ \\
$\mathrm{D}$ & $0.00 \overline{\mathrm{x}} \leq 0.10$ \\
$\mathrm{E}$ & $\overline{\mathrm{P}}<0.00$ \\
\hline
\end{tabular}

Source: adapted from Mateus and Bragança (2009).

For the performance quantification at the groups' level and quantification of the "Hydricity" Global Level (HGL), it is necessary to aggregate indicators, based on weighting systems. Aggregation is achieved on two levels:

- Group level: indicators are combined to summarize their performance at the level of each of the four thematic groups (G2, G3, G4, G5);

- "Hydricity" Global Level (HGL): after evaluating the city performance at groups level and analyzing the abacus with the indicators of G1, the last aggregation consists of synthesizing a single value (HGL), which represents the overall performance of the city. In the aggregation process of G2, G3, G4 and G5 equation (2) is used.

$$
\mathrm{I}_{\mathrm{j}}=\sum_{\mathrm{i}=1}^{\mathrm{n}} \mathrm{w}_{\mathrm{i}} \mathrm{x}_{\mathrm{i}}
$$

where:

Ij corresponds to the macro indicator value resulting from weighting of each indicator, category, or dimension (Ii) with the respective weight factor (wi) in the sustainability assessment. The sum of the weights used to obtain each of the three levels of macro indicators 
shall be equal to 1 .

The weighting factors to aggregate the indicators into groups (G2, G3, G4 and G5), and these should be pre-established into the "Hydricity" Global Level. According to Mateus and Bragança (2009). It is widely known that several decision makers prefer to communicate sustainability through a graduated scale. This represents not only the city's performance but also its performance against best and conventional practices (benchmarks). The normalized values are converted to a qualitative scale between E (lower "Hydricity") and A* (higher "Hydricity"), using equivalences shown in Figure 3. In this qualitative scale, level D represents the conventional practice and level A corresponds to best practice.

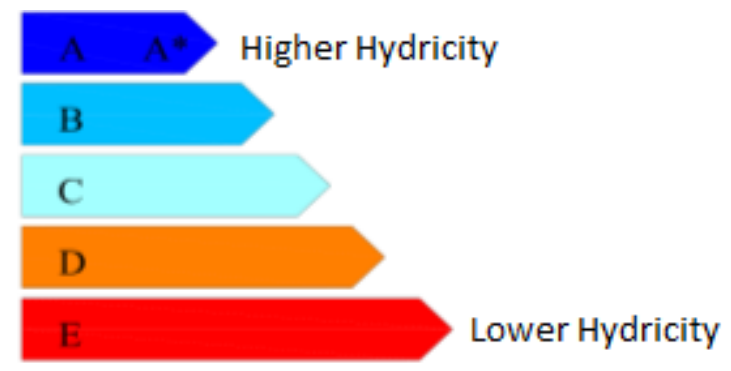

Figure 3. Graduated scale for city certification.

Source: adapted from Mateus and Bragança (2009).

\section{RESULT AND DISCUSSION}

An urban design that is more sensitive to water needs is of concern to managers. The dispersed city model may threaten the availability of water supply, which is especially detected when the river basin is adopted as the basic planning unit.

Other approaches that integrate issues concerned with water and urban sprawl began with a pioneering WSUD (2008) concept in Australia. This indicates that urban planning can be a valuable resource for improving habitability and support water-related ecosystems. However, much more comprehensively than the method proposed here, WSUD integrates all elements of the water cycle, and their interconnections are concomitantly considered to achieve a result that allows a healthy natural environment and that meets the needs of humans, including water for human consumption, wastewater and pollution, precipitation and runoff, watercourses and water resources, and floods. From this, it is concluded that more indicators should be added to the model proposed here, in order to fully diagnose the city's water.

According to the study, "Protecting Water Resources with Higher-Density Development" (US-EPA, 2006), higher-density development could better protect regional water quality, because it consumes less land to accommodate the same number of dwellings and requires best practices in run-off management, according to their context and densities. This approach ratifies the importance given to the indicators that associate the variables density and urban shape in the present study.

These approaches demonstrate that the proposed model is adjustable and can be improved with the addition of other indicators, especially those related to rainwater, which has no direct indicator. These comparisons point out possible improvements for the "Hydricity" assessment method; however, it is important to bear in mind that these studies were not developed for the Brazilian reality and are at a different stage of development.

In what concerns the integration method, it is important to interpret the results obtained from the indicators, making it possible to compare cities in sectorial and global ways, especially if there are regional planning initiatives or at the river basin level. 
However, the HGL must not be analyzed separately, since a critical analysis of the results is necessary, always one has to analyze the specific aspects of each indicator and the sectorial aspects of the groups. HGL is a relevant global result that can be used to foster the action of public agents and still serve for monitoring. The integration method can be used even if it is necessary to increase or reduce the number of indicators, which allows its adaptation to different cities, according to their peculiarities, just by adjusting the weighting system.

Another important aspect to be considered is that Group 1 indicators could also be standardized and integrated into the HGL calculation, facilitating the interpretation of the final result. However, it is important to have an independent format to evaluate the city's urban efficiency, where aspects of the city's shape and structural issues are confronted. If indicators are added to this group, and the abacus analysis system is maintained, it is important that it occurs in pairs so that a new axis is added to the abacus. It is understood that the abacus analysis can go beyond the simple comparison of the resulting shapes to perform a thorough analysis.

To exemplify the application of the method, Tables 4 and 5 present a case study in the city of Caxias do Sul which is a municipality in the state of Rio Grande do Sul (Brazil) with 435,482 inhabitants, with only $3.7 \%$ people living in rural areas (IBGE, 2010). With a total territorial area of $1,644 \mathrm{~km}^{2}$, it has only $744 \mathrm{~km}^{2}(45 \%)$ classified as rural areas. During its history, it has faced many problems due to lack of water, since it does not have rivers with high flow rates in its territory and it captures water in reservoirs originated by dams built in small river streams.

As can be observed, Caxias do Sul obtained a B, in the "Hydricity" Global Level. At the group's level, a B was obtained by two groups and an A* by another group. The lowest result occurred for Group 5, with a $\mathrm{C}$ rating. Caxias do Sul is far from the best practice in Group 1 (Figure 1), illustrating that it can improve significantly in Urban Efficiency, especially in the indicators related to the density and urban shape.

Table 4. Normalization and performance evaluation at the indicator level.

\begin{tabular}{|c|c|c|c|c|c|c|c|}
\hline Group & ID & $\begin{array}{l}\text { Value for Caxias } \\
\text { do Sul }\end{array}$ & $\begin{array}{c}\text { Best } \\
\text { Practice }\end{array}$ & $\begin{array}{l}\text { Conventional } \\
\text { Practice }\end{array}$ & Normalization* & $\begin{array}{c}\text { Adjusted } \\
\text { Normalization* }\end{array}$ & $\begin{array}{l}\text { Performance at } \\
\text { the Indicator } \\
\text { Level }\end{array}$ \\
\hline \multirow{9}{*}{2} & I-9 & 82.4 & 97.0 & 67.8 & 0.50 & 0.50 & B \\
\hline & $\mathrm{I}-10$ & 54.0 & 15.8 & 27.2 & $-2.35^{*}$ & $-0.20 *$ & $\mathrm{E}$ \\
\hline & $\mathrm{I}-11$ & 4.7 & 0.1 & 1.0 & $-3.69 *$ & $-0.20 *$ & $\mathrm{E}$ \\
\hline & $\mathrm{I}-12$ & 98.5 & 100.0 & 86.1 & 0.89 & 0.89 & A \\
\hline & I-13 & 30.0 & 100.0 & 20.0 & 0.13 & 0.13 & $\mathrm{C}$ \\
\hline & I-14 & 105.2 & 5.3 & 16.2 & $-8.19 *$ & $-0.20 *$ & $\mathrm{E}$ \\
\hline & $\mathrm{I}-15$ & 103.7 & 121.0 & 18.1 & 0.83 & 0.83 & A \\
\hline & I-16 & 11.0 & 1.1 & 21.8 & 0.52 & 0.52 & $\mathrm{~B}$ \\
\hline & $\mathrm{I}-17$ & 0.010 & 0.10 & 0.69 & 1.15 & 1.15 & $A^{*}$ \\
\hline \multirow{4}{*}{3} & I-18 & 56.8 & 40 & 70.0 & 0.44 & 0.44 & B \\
\hline & I-19 & 533.7 & 208.2 & 219.0 & -29.14 & $1.2 * *$ & $A^{*}$ \\
\hline & $\mathrm{I}-20$ & 225.4 & 93.9 & 24.3 & $2.89 *$ & $1.20^{*}$ & $A^{*}$ \\
\hline & $\mathrm{I}-21$ & 133.7 & 53 & 40.1 & $7.26 *$ & $1.20 *$ & $A^{*}$ \\
\hline \multirow{3}{*}{4} & $\mathrm{I}-22$ & 101.9 & 100 & 79.0 & 1.09 & 1.09 & $A^{*}$ \\
\hline & $\mathrm{I}-23$ & 16.5 & 100 & 20.0 & -0.04 & -0.04 & $\mathrm{E}$ \\
\hline & $\mathrm{I}-24$ & 18.0 & 25 & 5.0 & 0.65 & 0.65 & B \\
\hline \multirow[t]{2}{*}{5} & $\mathrm{I}-25$ & 4 & 82 & 3 & 0.01 & 0.01 & D \\
\hline & I-26 & 24 & 18 & 30 & 0.5 & 0.5 & B \\
\hline
\end{tabular}

*adjusted because values smaller than -0.2 and higher than 1.2 cannot be used.

**adjusted because the value of the best practice is smaller than the value of the conventional practice. 
Table 5. Performance at the group level and HGL.

\begin{tabular}{|c|c|c|c|c|c|c|c|c|c|}
\hline Group & ID & $\begin{array}{c}\text { Adjusted } \\
\text { Normalization }\end{array}$ & $\begin{array}{l}\text { Performance at } \\
\text { the Indicator } \\
\text { Level }\end{array}$ & $\begin{array}{c}\text { Indicator } \\
\text { WHEIGHT } \\
(\%)\end{array}$ & $\begin{array}{c}\text { Group } \\
\text { WHEIGHT } \\
(\%)\end{array}$ & \multicolumn{2}{|c|}{$\begin{array}{l}\text { Aggregation at } \\
\text { the group level }\end{array}$} & \multicolumn{2}{|c|}{$\begin{array}{c}\text { Hydicity Global } \\
\text { Level (HGL) }\end{array}$} \\
\hline \multirow{9}{*}{2} & I-9 & 0.50 & B & 18 & \multirow{9}{*}{25} & \multirow{9}{*}{0,41} & \multirow{9}{*}{ B } & \multirow{18}{*}{054} & \\
\hline & $\mathrm{I}-10$ & -0.20 & E & 10 & & & & & \\
\hline & I-11 & -0.20 & E & 8 & & & & & \\
\hline & $\mathrm{I}-12$ & 0.89 & A & 10 & & & & & \\
\hline & $\mathrm{I}-13$ & 0.13 & $\mathrm{C}$ & 12 & & & & & \\
\hline & $\mathrm{I}-14$ & -0.20 & E & 8 & & & & & \\
\hline & $\mathrm{I}-15$ & 0.83 & A & 8 & & & & & \\
\hline & $\mathrm{I}-16$ & 0.52 & B & 16 & & & & & \\
\hline & $\mathrm{I}-17$ & 1.15 & $\mathrm{~A}^{*}$ & 10 & & & & & $B$ \\
\hline \multirow{4}{*}{3} & I-18 & 0.44 & B & 20 & \multirow{4}{*}{25} & \multirow{4}{*}{1,05} & \multirow{4}{*}{$\mathrm{A}^{*}$} & & \\
\hline & I-19 & 1.20 & $\mathrm{~A}^{*}$ & 30 & & & & & \\
\hline & $\mathrm{I}-20$ & 1.20 & $A^{*}$ & 30 & & & & & \\
\hline & $\mathrm{I}-21$ & 1.20 & $A^{*}$ & 20 & & & & & \\
\hline \multirow{3}{*}{4} & $\mathrm{I}-22$ & 1.09 & $A^{*}$ & 30 & \multirow{3}{*}{15} & \multirow{3}{*}{0,57} & \multirow{3}{*}{$\mathrm{B}$} & & \\
\hline & $\mathrm{I}-23$ & -0.04 & E & 30 & & & & & \\
\hline & $\mathrm{I}-24$ & 0.65 & B & 40 & & & & & \\
\hline \multirow{2}{*}{5} & $\mathrm{I}-25$ & 0.01 & D & 50 & \multirow{2}{*}{35} & \multirow{2}{*}{0,26} & \multirow{2}{*}{$\mathrm{C}$} & & \\
\hline & $\mathrm{I}-26$ & 0,5 & B & 50 & & & & & \\
\hline
\end{tabular}

The analysis of the abacus together with the aggregation process of the group-level indicators should make it possible to validate the "Hydricity" Global Level. Caixas do Sul achieved a HGL score of B, through the aggregation of the performances of groups 2 to 5 . Thus, the following question should be asked: by the analysis of the abacus of Caxias do Sul for the indicators of Group 1, is it possible that "Hydricity" Global Level could be improved to an A? The answer is no, since Caxias do Sul's abacus shape is far from the best practices abacus. On another hand, the results for Group 1 would lower the HGL rating to C.

Based on this application, it is concluded that the method is good, with possible adjustments to be made and also broadening the indicators, especially those related to Group 5 - Support Capacity. These latter indicators are the most difficult to measure because they depend on geo-referenced data and accurate information. Certainly with more indicators of Support Capacity, the HGL of Caxias do Sul would be smaller. Another group that deserves revision is Group 3, since it considered the availability of water throughout the territory of the municipality, without analyzing the costs to collect water in very distant places. Due to the knowledge of the Caxias do Sul reality, it is believed that the HGL should not be higher than $\mathrm{C}$ and not smaller than $\mathrm{D}$, if the process is reviewed as a whole.

\section{CONCLUSION}

The main objective of the present study was to present indicators and means for their aggregation, i.e. to propose an assessment methodology that would allow a comparative analysis and the monitoring of cities. It was concluded that the proposed method can be a good strategy to perform diagnoses, although requiring adaptations to local specificities.

Despite the attempt to elaborate a practical and direct methodology to be used in urban management, it was concluded that municipalities require a minimum team of professionals. They should focus on the definition of diagnostic procedures, on the organization of the database, on-site supervision of monitoring stations, on decision-making, and on public 
policy-making, even at regional scale, allowing the diagnostic of conflicts between municipalities. Furthermore, it could be possible to monitor the effects of decision making. It was verified that the maximum simplification and practicality implemented respected the depth limits that the variables required. All these analyses were considered pertinent and relevant because they can be used for decision making in city management, enabling the improvement of their conditions.

\section{REFERENCES}

AGUDELO-VERA, C. M.; MELS, A. R.; KEESMAN, K. J.; RIJNAARTS, H. H. Resource management as a key factor for sustainable urban planning. Journal of Environmental Management, v. 92, n. 10, p. 2295-2303, 2011. http://dx.doi.org/10.1016/j.jenvman.2011.05.016

ANDRADE, L. M. S.; BLUMENSCHEIN, R. N. A nova Ecologia da Cidade: uma conexão importantes para a ciência e o Desenho Urbano. In: SEMINÁRIO NACIONAL SOBRE O TRATAMENTO DE ÁREAS DE PRESERVAÇÃO PERMANENTE EM MEIO URBANO E RESTRIÇÕES AMBIENTAIS AO PARCELAMENTO DO SOLO, 3., 10-13 set. 2014, Belém. Anais... Belém: UFPA, 2014.

ASSOCIAÇÃO BRASILEIRA DE NORMAS TÉCNICAS - ABNT. Nbr 12211:1992. Estudos de concepção de sistemas públicos de abastecimento de água - Procedimento. Rio de Janeiro, 1992.

BARTON, A. B.; ARGUE, J. R. A review of the application of water sensitive urban design (wsud) to residential development in Australia. Australian Journal of Water Resources, v. 11 n. 1, p. 31-40, 2007. http://dx.doi.org/10.1080/13241583.2007.11465309

BERNARDES, R. S.; SCÁRDUA, M. P.; CAMPANA, N. A. (Orgs). Guia para a elaboração de planos municipais de saneamento. Brasília: Ministério das Cidades; FUNASA, 2006. 150p.

CASTRO, L. M. A. Proposição de metodologia para a avaliação dos efeitos da urbanização nos corpos de água. Belo Horizonte. 2007. 297f. Dissertação (Programa de Pós-graduação em Saneamento, Meio Ambiente e Recursos Hídricos) - Universidade Federal de Minas Gerais, Belo Horizonte, 2007.

CONSELHO NACIONAL DE MEIO AMBIENTE - CONAMA (Brasil). Resolução ${ }^{0}$ 369: Dispõe sobre os casos excepcionais, de utilidade pública, interesse social ou baixo impacto ambiental, que possibilitam a intervenção ou supressão de vegetação em Área de Preservação Permanente-APP. Diário Oficial [da] União, n. 61, 29 mar. 2006, Seção 1, p. 150-151.

DICKIE, S.; MCKAY G.; IONS, L.; SHAFFER, P. CIRIA C687, Planning for SUDS: making it happen. London: CIRIA C68, 2010. 14p

DOS SANTOS, R. F. Planejamento ambiental, teoria e pratica. São Paulo: Oficina de Textos, 2004. 184 p.

GRUNWALD, A. Strategic knowledge for sustainable development: the need for reflexivity and learning at the interface between science and society. International Journal of Foresight and Innovation Policy, v. 1, n. 1, p. 150-167, 2004. http://dx.doi.org/10.1504/IJFIP.2004.004619 
INSTITUTO BRASILEIRO DE GEOGRAFIA E ESTATÍSTICA - IBGE. Demographic Census. 2010. Available in: http://censo2010.ibge.gov.br. Access in: Sep. 2016.

INSTITUTO TRATA BRASIL. Website. 2010. Available in: http://www.tratabrasil.org.br/. Access in: Sep. 2016.

MATEUS, R.; BRAGANÇA, L. Guia de Avaliação SBToolPT-H. Portugal: Associação iiSBE, 2009. Available in: http://www.mma.gov.br/port/conama/legiabre.cfm?codlegi=489. Access in: Oct. 2014.

PICKETT, S. T. A.; CADENASSO, M. L.; MCGRATH, B. Resilience in ecology and urban design: linking theory and practice for sustainable cities. New York: Springer Science, 2013. 499 p.

RODRÍGUEZ, M. I.; CUEVAS, M. M.; HUERTAS, F.; MARTÍNEZ, G.; MORENO, B. Indicators to evaluate water sensitive urban. WIT Transactions on The Built Environment, v. 168, n. 1, p. 371-382, 2015.

RUEDA, S. (Org.). Plan de indicadores de Sostenibilidad de Vitória Gasteiz. Vitoria Gasteiz: BCN Ecologia, 2009.

SISTEMA NACIONAL DE INFORMAÇÕES SOBRE SANEAMENTO - SNIS (Brasil). Diagnosis of water and sewage services. 2010. Available in: http://www.snis.gov.br/. Access in: Sep. 2016.

TANGUAY, G. A.; RAJAONSON, J.; LEFEBVRE, J-F.; LANOIE, P. Measuring the sustainability of cities: an analysis of the use of local indicators. Journal Ecological Indicators, v. 10, n. 2, p. 2010, 407-418, 2010. http://dx.doi.org/10.1016/j.ecolind.2009.07.013

THOMPSON, S. A. Water demand supply: management and planning. In: Water use, management, and planning in the united states. San Diego: Academic Press, 1999. p. 173-209. http://dx.doi.org/10.1016/B978-012689340-3/50006-2

TONG, S. T. Y.; LIU, A. J.; GOODRICHB J. A. Assessing the water quality impacts of future land-use changes in an urbanizing watershed. National Risk Management Research Laboratory, Cincinnati, Ohio, USA. Environmental Protection Agency Civil Engineering and Environmental Systems, v. 26, n. 1, p. 3-18, 2009. http://dx.doi.org/10.1080/10286600802003393

ULIAN, G. Avaliação Diagnóstica para a Gestão Urbana através de indicadores de "Hidricididade". 2015. PhD Thesis (PhD in Arquitecture and Urbanism) - Facultad de Arquitectura, Construción y Diseño, Universidad del BioBio, Concepción, 2015.

ULIAN, G.; LIMA, M.; CARTES, I. Indicadores de "Hidricidade" como ferramenta de avaliação da eficiência urbana. In: LATIN AMERICAN AND EUROPEAN CONFERENCE ON SUSTAINABLE BUILDINGS AND COMMUNITIES, 2015, 2123 July, Guimarães. Proceedings... Lisbon: Multicomp, 2015. v. 2. p. 11811190. 2015a.

ULIAN, G.; PINO QUILODAN, M. A.; LIMA, M.; CARTES, I. Aplicação de avaliação diagnóstica da eficiência urbana através de indicadores de "Hidricidade" ao município de Caxias do Sul. SIMPÓSIO DE HIDRÁULICA E RECURSOS HÍDRICOS DOS PAÍSES DE LÍNGUA PORTUGUESA, 12., 2015, Brasília. Trabalhos... São Paulo: ABRH, 2015b. 
UNITED NATIONS - UN. Universal declaration of water rights. $22^{\text {nd }}$ ed. Geneva, 1992.

UNITED STATES. Environmental Protection Agency - US-EPA. Protecting water resources with higher-density development. Washington, DC, 2006.

VITORIA GASTEIZ. Centro de Estudios Ambientales. Sistema de Información Ambiental. Atlas ambiental. Vitoria Gasteiz, 2014. Available in: http://www.vitoria- gasteiz.org. Access in: Sep. 2016.

WATER IN CORE. Sustainable water management through common responsibility enhancement in Mediterranean Rivers Basins. Rome: EuropaBook, 2012. p. 20.

WATER SENSITIVE URBAN DESIGN PROGRAM - WSUD. City of Melbourne WSUD guidelines applying the model SUD guidelines. Melbourne: Melbourne Water, 2008. p. 43.

WHISTON, A.; SPIRN, A. Ecological urbanism: a framework for the design of resilient cities. In: PICKETT, S. T. A.; CADENASSO, M. L.; MCGRATH, B. (Eds.). Resilience in ecology and urban design: Linking theory and practice for sustainable cities. Dordrecht: Springer Science Business, 2013.

ZARAGOZA. Ordenanza municipal para la ecoeficiencia y la calidad de la gestión integral del agua. Zaragoza, 2011. Available in:

http://www.zaragoza.es/ciudad/normativa/detalle_Normativa?id=1542. Access in: Sep. 2016. 


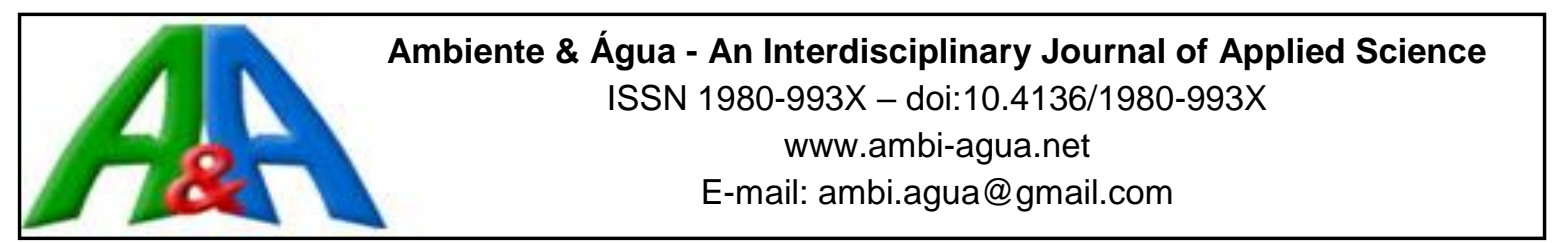

\title{
Natural vector multi-agents geo-inspired in environmental management
}

\author{
doi:10.4136/ambi-agua.1912
}

Received: 05 Apr. 2016; Accepted: 29 Oct. 2016

\author{
Edwin Eduardo Millán $\operatorname{Rojas}^{*}$; José Nelson Pérez Castillo ${ }^{2}$ \\ ${ }^{1}$ Universidad de la Amazonia (UDLA), Florencia, Colombia \\ ${ }^{2}$ Universidad Distrital Francisco José de Caldas, Bogotá, Colombia \\ "Corresponding author: e-mail: e.millan@udla.edu.co, \\ jnperezc@correo.udistrital.edu.co
}

\begin{abstract}
Environmental management requires new models to minimize or control the effects of environmental problems on the population. The complexity of environmental problems requires conducting studies to develop models to adjust the environment's dynamics. The proposed geo-inspired model of natural vector multi-agents (Multi-AVNG) allows for the computational observation of the dynamism of the environmental entity studied. This model is based on the theory of vector agents, changing its structure to include the environmental dynamic aspect using only two behaviors, the natural and the induced, through the vector model in geographic information systems and a function which will control the progression of the environmental entity according to the model's defined parameters.
\end{abstract}

Keywords: environmental behavior, multi-Agent model, simulation.

\section{Agentes naturais multi vetores geo-inspirados na gestão ambiental}

\section{RESUMO}

A gestão ambiental requer novos modelos para minimizar ou controlar os efeitos sobre a população causados por problemas ambientais. A complexidade dos problemas ambientais requer a realização de estudos para o desenvolvimento de modelos para ajustar a dinâmica do ambiente. O modelo de geo-inspiração proposto de vetor multi-agentes natural (Multi-AVNG) permite assistir computacionalmente o dinamismo do órgão ambiental estudado. Este modelo é baseado na teoria de agentes vetores, alterando a sua estrutura para incluir o aspecto ambiental dinâmico usando apenas dois comportamentos, o natural e o induzido, por meio do modelo de vetor em sistemas de informação geográfica e uma função que controla a progressão da entidade ambiental de acordo com os parâmetros definidos para o modelo.

Palavras-chave: gestão ambiental, modelo de multi-agente, simulação.

\section{INTRODUCTION}

Environmental problems are complex and dynamic, and they affect the population in general. Climate change, water resources, the use of land, flora and fauna, among others, are 
aspects that require further input from the computer science field in order to model dynamic structures in natural behaviors of the environment and to include functions or control variables for the decision- making process (Cuesta and Becerra, 2012).

Nowadays there are many computational structures (cellular automated, neural networks, genetic algorithms, Neuro-genetics, fuzzy logic, Agents, Multi-agent Systems, etc.) (Batty, 2000; Jayawardena et al., 2014; Vitabile et al., 2009; Chen et al., 2008, Santamaría et al., 2015). These studies contribute to solving the problems of information management and decision-making.

We present a computational structure based on bio-inspired computing in the field of natural agents and the vector model of geographic information systems for decision-making in environmental management. We propose to model the environmental problem from two behaviors:

1) natural behavior, which owns the entity in the normal state and is influenced by a random variable; and

2) induced behavior, which is generated by altering the natural behavior of the entity by environment's variables or functions.

A computational framework was formulated that integrates the concept of agent with the vector model and the control of variables in environmental management, with the purpose of presenting a dynamic model which can visualize, in a geographic information system, the natural and the induced behaviors by nature or by man according to the case study.

A generic model is built based on the Euclidean geometry of the vector model (point, lines, polygons) including the dynamic behavior of a natural agent. This model was developed in JADE and Geotools, which are widely proven tools.

General aspects were established for the implementation of the AVNG in environmental management, for which we present the model structure and variables or behaviors to remember at the time of analysis and construction. Additionally, we present an application of the model in an environmental problem related to the flooded urban areas.

In the results, the data generated by the Multi- AVNG model versus the flooded urban areas are presented. These results were compared with an evaluation method used by (Horritt and Bates, 2002) which was used to calculate in percentage the areas generated by the model against historical data obtained from a map of the flooded area.

We also investigated models that support environmental management based on computer science inspired by environmental phenomena. There are also comments about related works in the area of vector agents. This model will help to dynamically visualize the elements or entities involved in the several environmental problems. For this purpose, the model is based on two behaviors which can be fed back or defined in multiple ways.

\section{Model natural vector agents inspired in environmental management or geo-inspired (AVNG)}

In this section, theoretical aspects related to the origin of the AVNG are presented, giving a brief explanation of the vector agents (Hammam et al., 2007) and their difference with the natural vector agents as proposed in this paper, as well as the environmental management inspired by elements that complete the structure of AVNG. The description of the geometrical aspects of the vector model is included and as well as an explanation of how all these aspects are integrated into the proposal of the geo-inspired natural vector agents.

\subsection{Proposal of a geo-inspired natural vector agent (AVNG)}

The AVNG is founded on the integration of the environmental aspects modeled in two 
behaviors and the use of the theory of vector agents (Hammam et al., 2007) based on Euclidian geometry. A geo-inspired natural vector agent represents a geographic or environmental entity in which two behaviors can be modeled: the natural and the induced. The first behavior corresponds to the natural state of the entity, its role in nature, which can be modified by physical variables without significant changes. In this study, the natural variables were modeled randomly. The second behavior is the one presented by the entity when it overflows the natural function. This occurs when it is affected by one or more generated physical variables. At that time, the natural behavior is transformed into induced behavior.

After these behaviors, the geographical function was established, which helps to integrate the visual component systems of geographic information from the vector model that represents entities through primitives (points, lines or polygons). Each geographic entity has an initial vector that represents it. Natural behavior is associated with the initial vector and from this the necessary adjustments are made toward the induced behavior, to show its spatial variation. The last component is the function of environmental management that provides the control for the behavior variable or induced function of the agent.

\subsection{Variables and functions to consider}

The elements to consider in the analysis of an environmental problem at the time of modeling the Multi-AVNG are set forth below. We need to identify these elements to properly structure the operation of agents. The problem to address is the visualization of the flooded areas after a strong precipitation.

Natural behavior. The natural form, from the mathematical and computational points of view, can be defined as a function, which represents the natural behavior of the entity. For this study, we will call it $(q)$, where the value of this function is represented according to what is to be studied, e.g. the flow of a river.

Induced behavior. For practical purposes, this agent's function was defined as the behavior that the agent assumes once it has been influenced by the variable or the function of the environment; this function is called $I(q)$, e.g. the flow of a river's flooding.

The environment's function or variable. This function or variable of the environment is responsible for altering the natural behavior and setting the induced behavior in the environmental entity studied. In the case that it is variable, it can be one or several variables involved in the change of behavior of the environmental entity. As an example of this, based on the initial environmental problem, we can speak of the rainfall.

Memory. This is the variable that stores the induced behavior in a time (t) to be transmitted to the same AVNG or another in its context.

Geographic feature. The geographical feature is what allows vectoring the induced behavior from the difference between its two behaviors in a range of time-definite (Equations 1, 2, 3 and 4).

$$
\mathrm{G}\left(\text { dist }_{\mathrm{i}}\right)=\mathrm{E}\left(\text { dist }_{\mathrm{i}}\right) * \mathrm{C}
$$

With $(\mathrm{M})$ memory $=0$, the equation is shown below:

$\mathrm{E}\left(\right.$ dist $\left._{\mathrm{i}}\right)=\sqrt[r]{(\mathrm{I}(\mathrm{q})-\mathrm{N}(\mathrm{q})) * \mathrm{~F}(\mathrm{t})}$

With (M) memory $>0$ the equation takes form:

$\mathrm{E}\left(\right.$ dist $\left._{\mathrm{i}}\right)=\sqrt[\mathrm{r}]{\mathrm{I}(\mathrm{q}) * \mathrm{~F}(\mathrm{t})}$ 


$$
\begin{array}{lll}
\text { lat }_{0} & \left(\operatorname{long}_{0}+\mathrm{G}\left(\text { dist }_{0}\right)\right) & \mathrm{h}_{0} \\
\text { lat }_{1} & \left(\operatorname{long}_{1}+\mathrm{G}\left(\text { dist }_{1}\right)\right) & \mathrm{h}_{1} \\
\text { lat }_{\mathrm{n}} & \left(\operatorname{long}_{\mathrm{n}}+\mathrm{G}\left(\text { dist }_{\mathrm{n}}\right)\right) & \mathrm{h}_{\mathrm{n}}
\end{array}
$$

where:

$F(t)=$ Function or variable of time;

$N(q)=$ Natural behavior;

$I(q)=$ Induced behavior;

$\operatorname{lat}_{n} ; \operatorname{long}_{n}=$ values for latitude and longitude in the $\mathrm{n}$ section;

$h_{n}$ value of altitude at the point $\mathrm{n}$;

$\mathrm{C}$ is a constant derived from the unit of measure of the shapefile of reference given in meters; and

$$
G\left(\text { dist }_{i}\right)=\text { to the geographical function that calculates the distance the vector moves. }
$$

We work with the vector model and define the primitive and the spatial reference system to analyze each vector agent; $r$ is the integer value that assumes the root; this will depend on the induced behavior units, e.g. for $\mathrm{r}=1 ; \mathrm{m}^{2}, \mathrm{r}=2$ y para $\mathrm{m}^{3} \mathrm{r}=3$.

Environmental management function. The environmental management function is the one which controls the induced behavior of the entity. This function seeks to have degrees of tolerance between the natural behavior and the induced behavior, for issuing an alert when it is above the limits.

\section{RESULTS}

As a result of the implementation of the Multi-AVNG system, the study area and the source of the data for the system was determined, the data set was constructed for processing, the vectorization environmental entity was studied, and a comparison was made between the area generated by the AVNG model and the historical area demarcated by the event that occurred on April 28, 2000.

\subsection{Multi-AVNG system to determine a flooded urban area}

For the use of the Multi AVNG system, a case study is presented to address the problem of the flooded areas in an urban center. For that purpose, the study area is described and the functions and behaviors to model for the use of the proposed system are determined.

\subsubsection{Case study}

La Perdiz stream, located in the Amazon region, in the southeast of Colombia, South America between $00^{\circ} 42^{\prime} 17$ " of South latitude and $02^{\circ} 04^{\prime} 13$ "North latitude and $74^{\circ} 18^{\prime} 39^{\prime \prime}$ and $79^{\circ} 19^{\prime} 35$ " longitude West, representing $7.8 \%$ of the territory Colombian, lies in the municipality of Florencia, capital of the Department of Caquetá. This river represents a clear example of the damage that small streams can cause in urban centers. Flooding in the stipulated conditions has been little studied in this part of the world, given the conditions of the Amazonian foothills, where the mountainous landscape converges with plains; this variety of landscape makes it the ideal place to test the AVNG model for the definition of probable flooded areas. 


\subsubsection{Data source to apply to the Multi-AVNG system for study}

The development of the geographical work had multiple sources of digital information, enabling the performance of the case study. The main sources were the land ordinance plan (POT); a satellite image of Landsat 7 (La Perdiz River Basin); nine (9) aerial photography flights C-2173 IGAC; and three (3) official plates IGAC, numbered 389-VI-C and 413-II-A Scale C 1: 25000. Based on these data, networks of irregular triangles (TIN) and the base layers of the vectors representing the environmental agency (La Perdiz River) were obtained.

The hydrographic data were obtained from the Institute of Hydrology, Meteorology and Environmental Studies of Colombia (IDEAM, after its abbreviation in Spanish). The data from 1969 to 2014 were obtained from the stations that the IDEAM has in the region. Based on these data, the study of the worst flooding that the municipality has suffered was consolidated and the water flow that generated these floods was established, to test the model in a known context and to validate the data with recorded historical data and flooded areas, which were demarcated with precipitation. On May 24, 2003, ten districts were flooded, injuring approximately 1,500 people.

The most disastrous effects occurred in the road infrastructure and in the networks of the aqueduct, the services of which were suspended for more than ten days in some districts of the city. Two months later, on July 14th of the same year, a new hydro-climate event occurred which injured a reported 1,030 families, for a total of 5,200 affected people.

\subsubsection{Definition of the test dataset}

The test dataset was built with the recorded precipitations at the meteorological station. A consolidated 12-hour time lapse was done to determine the behavior of the basin with certain pre-set values with intervals of an hour, because historically, the sudden floods caused by rain took place between three to six hours; a margin for the consolidation of the results was maintained. In addition, the physical parameters of the basin, as area and velocity of flows in the stipulated sections, were integrated to define the parameters of the Natural function. The Induced function occurs when the precipitation or rainfall is greater than 0 in the one-hour time lapse.

The file can be built as a table in Excel or a flat file for which some libraries of the source code must be modified. Fixed values taken from the historical data of the time of one of the severe floods that have occurred in this territory were used for the simulation. On April 28, 2000, approximately 65, 60 and $150 \mathrm{~mm}$ of rain (IDEAM, 2015) fell for a period of three hours. For future work, the file can be linked with sensors located in the course of the basin and in this way to achieve data in real-time.

\subsubsection{Vectorization of the geographical entity (La Perdiz stream)}

From the geographical information obtained from data sources already stipulated, a set of vectors was defined that will represent the entity to process. This research identified the area and shape of the basin, important factors for the calculation of the induced behavior. The geographic entity for the case study, La Perdiz stream, was divided into 71 tranches, by noting 71 variations of its descent along the path from its origin to where it flows into the Hacha River. The purpose of this division is to have minor variations in the shape of the volume of water that runs along the riverbed. Once the entity is vectored, it is input to the AVNG system.

The flexibility of the vector model in GIS allows one to represent any entity through its primitives. It is necessary to perform a preliminary analysis to determine which of them is the one that represents correctly the appropriate scale for the geographic entity of the study. 


\subsubsection{Definition and processing of the Multi-AVNG system}

When the entries are defined (the dataset and the vector representing the geographic entity for the AVNG) an area demarcated by vectors that were affected by the overflowing water is obtained.

Once the data were entered into the AVNG (Dataset), each of the paths of the entity are analyzed and checked to determine if the entity is in its Natural behavior or changes to its Induced behavior, for which rainfall values supplied by the Dataset are verified. Once comparison is done, the next step is to store the value modified in the stretch in the variable memory. This value sends a message through to the following AVNG, which is monitoring the next section. The value obtained from the sent message becomes an additional entrance to the AVNG that receives it and it accumulates to the flow of the Natural or Induced function given the situation. In this way, all AVNG communicate as a cascade from the birth of the La Perdiz stream to its mouth.

The geographic function is initialized with the values obtained in each section before being sent to the next AVNG. These are functions take the values of the original vector' points and modify them by adding the values generated by the induced function to create vectors to move the original stretch. The area obtained from the execution of the AVNG is displayed in Figure 1, where it is demarcated from vectors that move from the original vector to the left or right according to the induced function, which is affected by the slope, rainfall values and the flow generated by precipitations.

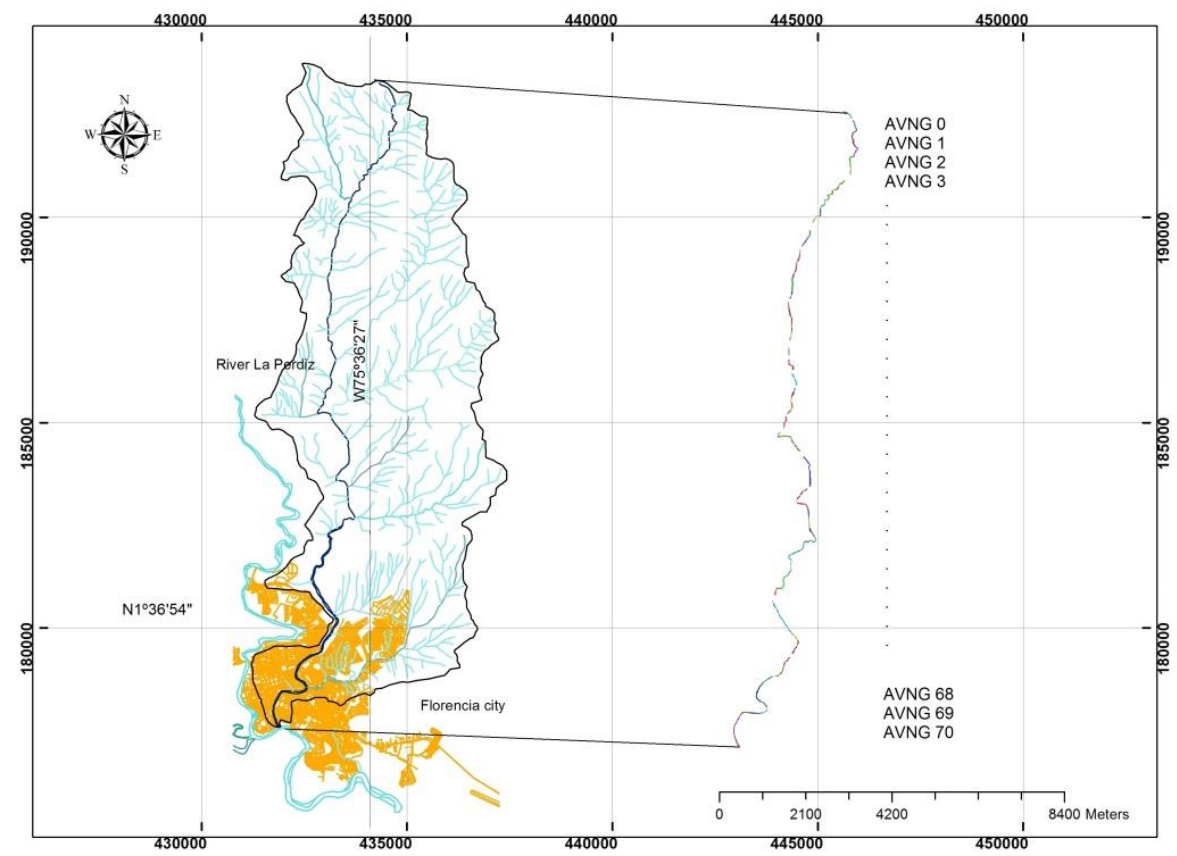

Figure 1. Environmental entity is divided into equal vectors slope and is assigned a AVNG to monitor behaviors.

\subsection{Comparison of the areas between the Multi-AVNG system and the flooded area}

The city of Florence is shown in Figure 2; in the larger scale it is divided by neighborhoods, streets, roads and avenues. The urban area is at the South part of the municipality of Florence and it is crossed by multiple sources of water including the $\mathrm{La}$ Perdiz stream. 


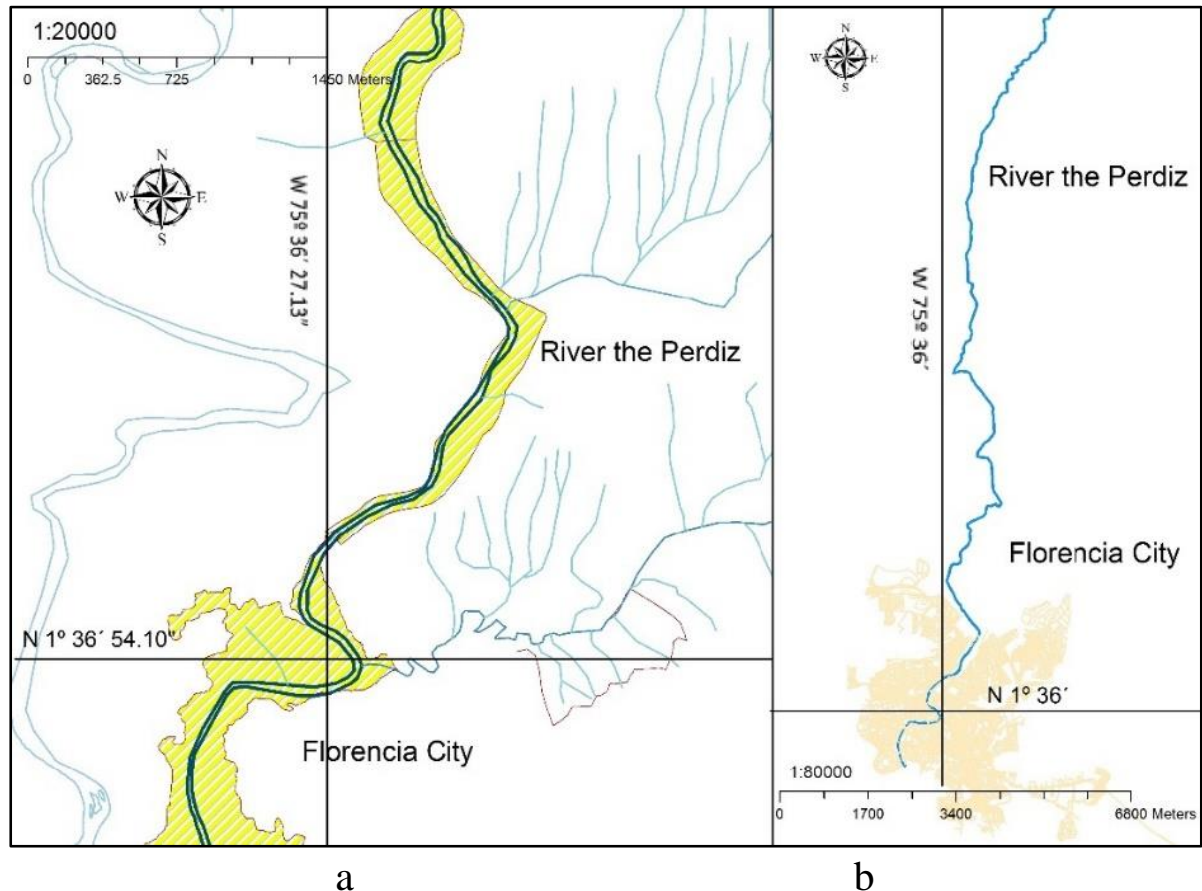

Figure 2. Area flooded historically (yellow) and a channel of the water entity. Figure $2 a$, the entity hydric basin. Figure $2 b$.

A shapefile that defines this area was obtained from the satellite image showing the flooded area and compared with the vectors generated by the Multi-AVNG system that obtained a shapefile with the generated sections; see Figure 3. The comparison of the two results is shown in Figure 4, where there is evidence of differences between the defined area and the obtained by the AVNG.

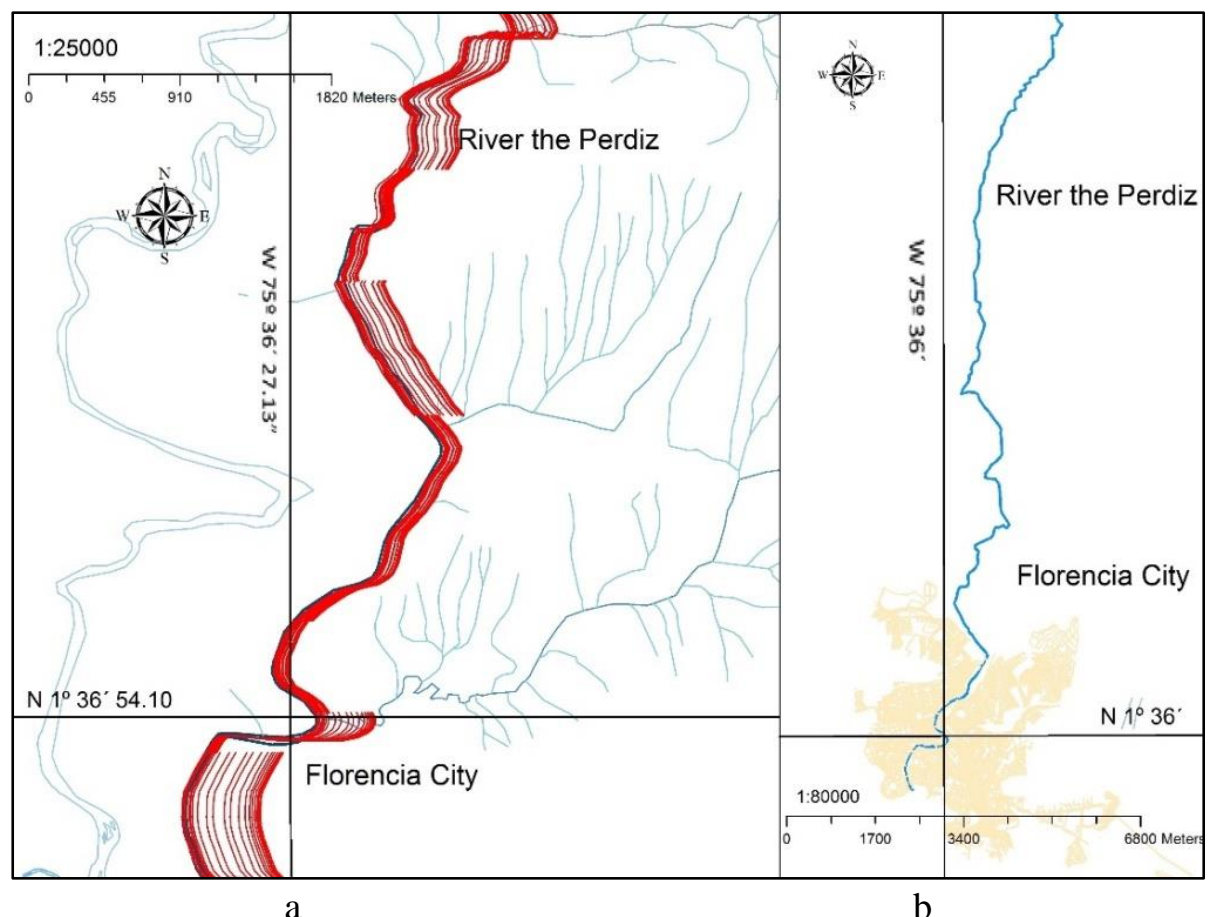

Figure 3. Area marked by the AVNG. Figure 3a, the entity hydric basin. Figure $3 b$. 


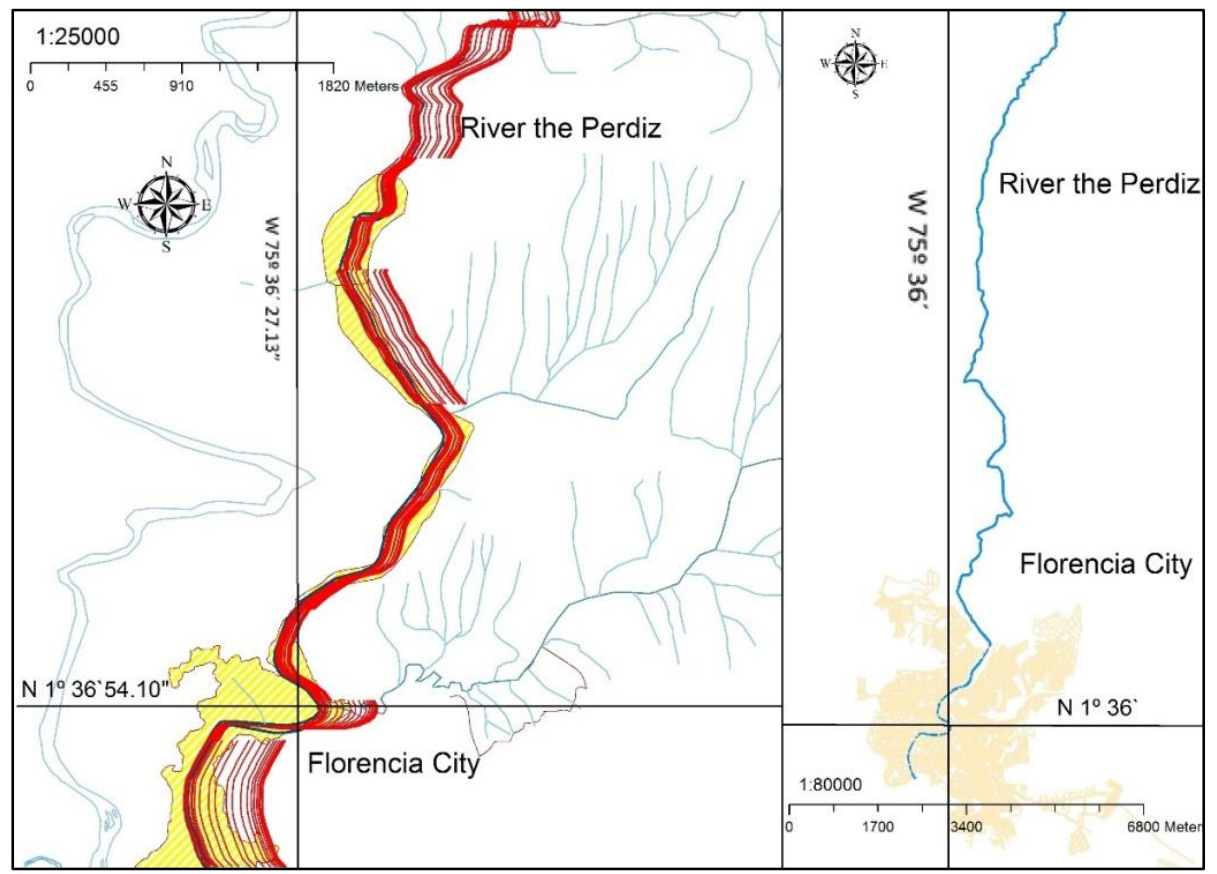

Figure 4. Historically flooded area (yellow) versus the area generated by the AVNG system (red).

Once the areas generated by the Multi-AVNG system were obtained, the next step was to take the farthest vector from the origin vector, to the left and the right sides to get an area over the TIN or raster-generated. From this information, the method used by (Horritt and Bates, 2002) was employed to calculate the percentage of approximation of the flooded area and the area generated by the system, for which Equation 5 was used.

$$
F=\frac{\operatorname{Num}\left(S_{\text {mod }} \cap S_{o b s}\right)}{N u m\left(S_{\text {mod }} \cup S_{o b s}\right)} \times 100
$$

where:

$S_{\text {mod }}$ y $S_{\text {obs }}$ are the sets of domain sub-regions (pixels, items or cells) shown as flooded by the model and the historical data reflected in maps or satellite images; and

$\operatorname{Num}(\bullet)$ denotes the number of members of the joint.

Therefore, it varies between zero, for the model without overlapping between the flooded areas, and 100, for a model in which the forecast data fully coincide with those observed (Horritt and Bates, 2002). The results can be seen in Table 1.

Table 1. Results in percentage of the flooded area generated by the Multi-AVNG model vs. flooded area.

\begin{tabular}{lccc}
\hline \multicolumn{1}{c}{ Data } & $\begin{array}{c}\text { Generated area vs. } \\
\text { Flooded area (\%) }\end{array}$ & Error submitted (\%) & With settings \\
\hline $\begin{array}{l}\text { Event April 28, 2000 } \\
\text { (flooded area) }\end{array}$ & 100.0 & 0.0 & No \\
Multi- GNVA Model & 70.3 & 29.7 & No \\
$\begin{array}{l}\text { No event Multi- } \\
\text { GNVA Model }\end{array}$ & 95.8 & 4.2 & No \\
\hline
\end{tabular}

As it can be seen, when using the method of comparison, 70.29 percent of flooded area was obtained from the Multi-AVNG model, which consolidated a clear area where the 
induced behavior of the agents was an influence. In addition, the model was assessed when there were no rainfall data of catastrophic events. The result was the natural riverbed of the environmental entity; in other words, the system exposed only the natural behavior of the entity, in this case with $95.78 \%$ of area in relation to the normal course of the environmental entity. It is important to be clear that further testing with different events is needed, but in the demonstration, agents change their behaviors and reflect, in the structure of their vector model, an approximation to the behaviors of the environmental entity. Further work can be developed to improve the results.

\section{DISCUSSION AND CONCLUSIONS}

While investigating related works such as geographical vector agents, we found a paper from Hammam et al. (2007) which uses Euclidean geometry to generate an autonomous entity making use of the vector model, based on the concept of cellular automaton (Batty, 2000).

Environmental and geographical features were integrated into the system agents to have a flexible structure in the representation of water environmental entities.

In this paper, the concept of the geo-inspired natural vector agent was addressed from the concept of vector agent inspired by the environmental management. The AVNG formulates the creation of a multi-agent system based on the entity's natural behavior and induced behavior by variables or environmental functions.

A computational implementation of the Multi-AVNG model was developed on the JADE platform with the use of the Geotools library. The selected library allows using point primitive lines or polygons to represent dynamic environmental entities and their problems, from modeling their natural and induced behaviors and also monitoring through the geographical feature and environmental management.

The Multi-AVNG system differs significantly from geographical delivery agents in the following areas: it does not change the initial vector and the results can be displayed in a new set of vectors. The origin vector can be validated with the results; the controls can be included in the process of generating the results and induced behaviors can be monitored, according to the parameters required for the system, managing in this way an approximation of the environmental entity's behaviors that the user wishes to study.

Future work can be presented, as case studies in environmental problems related to the use of the soil, climate, flora and fauna. Also, in the same category of water resources but focused on other situations, the Multi-AVNG system can be used to monitor and highlight environmental problems.

\section{ACKNOWLEDGMENTS}

This article is based on the doctoral thesis "An approach to environmental management Piedemonte Colombian Amazonico (Florence, Caquetá) from computer bioinspired high performance" which was researched under the auspices of the Ph.D. program in engineering at the University Distrital "Francisco José de Caldas", Bogotá, Colombia and with the support of the University of Amazonia in Florencia, Caquetá, Colombia.

\section{REFERENCES}

BATTY, M. Geocomputation using cellular automata. Geocomputation. New York: Taylor \& Francis, 2000. p. 95-126. 
CHEN, S. H.; JAKEMAN, A. J.; NORTON, J. P. Artificial intelligence techniques: an introduction to their use for modelling environmental systems. Mathematics and Computers in Simulation, v. 78, n. 2, p. 379-400, 2008. http://dx.doi.org/10.1016/j. matcom.2008.01.028

CUESTA, F.; BECERRA, M. T. Biodiversity and climate change in the Andes: Importance of monitoring and regional work. Virtual magazine. REDESMA, v. 6, p. 19-32, 2012.

HAMMAM, Y.; MOORE, A.; WHIGHAM, P. The dynamic geometry of geographical vector agents. Computers, Environment and Urban Systems, v. 31, n. 5, p. 502-519, 2007. http://dx.doi.org/10.1016/j.compenvurbsys.2007.08.003

HORRITT, M. S.; BATES, P. D. Evaluation of 1D and 2D numerical models for predicting river flood inundation. Journal of Hydrology, v. 268, n. 1, p. 87-99, 2002. http://dx.doi.org/10.1016/S0022-1694(02)00121-X

INSTITUTO DE HIDROLOGÍA, METEOROLOGÍA Y ESTUDIOS AMBIENTALES IDEAM. Data IDEAM. Available in: http://www.ideam.gov.co. Access: 17 Jan. 2015.

JAYAWARDENA, A. W.; ZHU, B.; AMARASEKARA, J. D.; VEREIVALU, V. A. Comparative study of fuzzy logic systems approach for river discharge prediction. Journal of hydrology, v. 514, p. 85-101, 2014. http://dx.doi.org/10.1016/j. jhydrol.2014.03.064

SANTAMARÍA, B.; BALLESTEROS, J.; GONZÁLEZ, J. S. Cloud computing platform as technological infrastructure for virtual, remote and adaptive laboratories. Scientific Journal, v. 3, n. 23, p. 98-110, 2015.

VITABILE, S.; CONTI, V.; MILITELLO, C.; SORBELLO, F. An extended JADE-S based framework for developing secure Multi-Agent Systems. Computer Standards \& Interfaces, v. 31, n. 5, p. 913-930, 2009. http://dx.doi.org/10.1016/j.csi.2008.03.017 


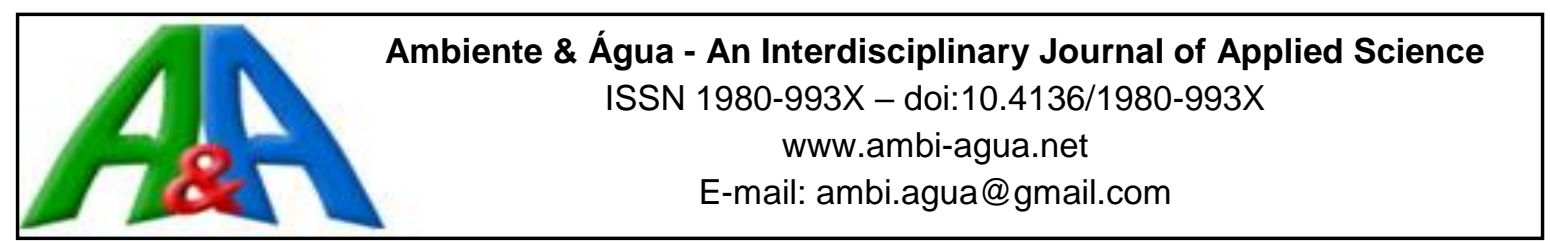

\title{
Incertezas e erros na estimativa de vazões usando modelagem hidrológica e precipitação por RADAR
}

\author{
doi:10.4136/ambi-agua.1924
}

Received: 20 Apr. 2016; Accepted: 19 Oct. 2016

\author{
Samuellson Lopes Cabral ${ }^{*}$; Jojhy Sakuragi ${ }^{1}$; Cleiton da Silva Silveira ${ }^{2}$ \\ ${ }^{1}$ Centro Nacional de Monitoramento e Alertas de Desastres Naturais (CEMADEN), \\ São José dos Campos, SP, Brasil \\ Coordenação de Operações e Modelagens \\ ${ }^{2}$ Universidade da Integração Internacional da Lusofonia Afro-Brasileira (UNILAB), \\ Redenção, Ceará, Brasil \\ *Autor correspondente: e-mail: samuellson.cabral@cemaden.gov.br, \\ jojhy.sakuragi@cemaden.gov.br, cleitonsilveira@unilab.edu.br
}

\section{RESUMO}

Esse artigo apresenta uma análise das incertezas e erros do modelo SCS-CN do Hydrologic Engineering Center - Hydrologic Modeling System (HEC-HMS), para eventos hidrológicos com dados de precipitação observada e estimada por RADAR na bacia do rio São Miguel em Alagoas, que controla uma área de $296 \mathrm{~km}^{2}$. Foram utilizados dados fisiográficos para as estimativas iniciais dos parâmetros do SCS-CN. Em seguida, utilizando medidas simultâneas de precipitação e vazões observadas, os parâmetros foram calibrados. Utilizando-se dados independentes, os parâmetros calibrados foram validados. O coeficiente de desempenho mostrou valores de Nash-Sutcliffe de 0,93 na fase de calibração e valores entre 0,81 a 0,87 nas fases de validação. Em seguida, o modelo foi utilizado para eventos hidrológicos passados, usando dados de precipitação estimada por RADAR. Obteve-se coeficientes de Nash-Sutcliffe entre 0,75 a 0,79 . O SCS-CN com as estimativas de precipitação pelo RADAR representou de forma adequada o tempo das vazões de pico, entretanto, subestimou a magnitude do pico com erros de até $26 \%$ em alguns eventos. A metodologia mostrou-se satisfatória para a bacia em estudo e pode ser uma ferramenta útil para aplicação em outras bacias hidrográfica prevendo possíveis inundações.

Palavras-chave: gestão dos recursos hídricos, inundação, SCS.

\section{Uncertainties and errors flow estimate using hydrological modelling and precipitation by RADAR}

\begin{abstract}
This work presents an analysis of uncertainties and errors of the SCS-CN model of the Hydrologic Engineering Center - Hydrologic Modeling System (HEC-HMS), for hydrological events using observed and RADAR-estimated precipitation data of the São Miguel River Basin in State of Alagoas, which covers an area of $296 \mathrm{~km}^{2}$. Physiographic data of the basin were used to find the initial estimates of the SCS-CN parameters. Then, using simultaneous measurements of precipitation and observed flow, the parameters were calibrated. Using
\end{abstract}


independent data series, calibrated parameters were validated. The performance coefficient showed Nash-Sutcliffe values of 0.93 in the calibration phase and between 0.81 and 0.87 in the validation phase. The model was then used for past hydrological events, using RADARestimated precipitation data. This resulted in Nash-Sutcliffe coefficients between 0.75 and 0.79. The SCS-CN model with RADAR-estimated precipitation represented the time of the peak flow adequately; however, it underestimated the magnitude of the peak with errors up to $26 \%$ in some events. The methodology had satisfactory results for this basin and can be a useful tool for the prediction of flooding in other watersheds.

Keywords: flooding, SCS, water resources management.

\section{INTRODUÇÃO}

A modelagem hidrológica é uma importante ferramenta no planejamento e gerenciamento de programas de recursos hídricos de bacias hidrográficas, auxiliando a previsão hidrológica. Os modelos hidrológicos necessitam de dados fisiográficos e dados temporais de chuva e vazão para uma melhor representação dos processos.

A análise de incertezas em modelos hidrológicos tem sido objeto de estudo de vários pesquisadores que assinalam a importância de se conduzir esse procedimento para que se tenham modelos que, de fato, representem mais acuradamente a realidade (Beck, 1987; McIntyre e Wheater, 2004; Muleta e Nicklow, 2005; Oreskes et al.,1994).

A incerteza na modelagem surge devido às informações incompletas usadas na simulação que estão na estrutura do programa de modelagem, nos parâmetros e nos dados de entrada. Em face disso, os autores sugerem que cada esforço de modelagem seja acompanhado de uma análise de incertezas com o objetivo de se determinar os intervalos de confiança das predições do modelo, levando em conta as várias fontes de incerteza. Esse procedimento é altamente recomendável quando a modelagem é aplicada, especialmente, para a tomada de decisão em políticas públicas.

Embora existam várias fontes de incertezas que afetam a precisão da resposta hidrológica em bacias hidrográficas, a precipitação é sem duvida umas das principais fontes de incertezas (Krzysztofowicz, 1999; 2001; Hossain e Anagnostou, 2004; Hossain et al., 2004; Kavetski et al., 2006a; 2006b; Nikolopoulos et al., 2010).

Segundo Cabral et al. (2016), quantificar a distribuição das precipitações sobre a terra é de suma importância para a compreensão da hidrologia de superfície. Essa quantificação pode desempenhar um importante papel na previsão e no monitoramento de fenômenos hidrometeorológicos. Entretanto, muitas das áreas propensas a esses fenômenos sofrem com a falta de dados pluviométricos confiáveis e sem falhas em sua série.

Radares meteorológicos permitem uma boa amostragem espacial e temporal da estimativa da taxa de precipitação, mas, por causa das fontes de erro, apresentam uma incerteza maior do que uma rede de pluviômetros.

Assim, tanto as medições de chuva com a rede de pluviômetros quanto às estimativas de chuva com o radar meteorológico possuem erros. As fontes de erro de medição de chuva com o radar meteorológico estão associadas à calibração eletrônica do equipamento, à equação de transformação da refletividade efetiva em taxa de precipitação (ou relação Z-R), ao efeito da curvatura da Terra, à zona de derretimento de cristais de gelo na nuvem, entre outras (Gonçalves, 2005). Da mesma forma, as medidas de chuva por pluviômetros não possuem representatividade espacial e a ação do vento pode causar uma diminuição da coleta de gotas pelo pluviômetro, entre outras.

Apesar dos erros de medição do radar e dos pluviômetros não serem bem conhecidos, as estimativas de chuva com o radar meteorológico e as medições de chuva com a rede de 
superfície podem ser combinadas para diminuir esses erros.

Sendo assim este artigo tem o objetivo de analisar as incertezas e erros na estimativa das vazões na bacia hidrográfica do rio São Miguel em Alagoas, utilizando dados de precipitações observadas e estimadas por RADAR como entrada em um modelo hidrológico SCS-CN do HEC-HMS.

\section{MATERIAL E MÉTODOS}

A bacia de drenagem do rio São Miguel está situada entre a Zona da Mata e o Agreste Alagoano (Figura 1). A bacia drena uma área de $624 \mathrm{~km}^{2}$, ao longo do curso de $90 \mathrm{~km}$ de extensão que perfaz o seu canal principal.

A estação chuvosa está entre o outono-inverno, com chuvas de março que ocorrem vindas do norte, e chuvas do principal período de sudeste, de abril-maio até junho-julho, mas com algumas interrupções. A montante da bacia, a precipitação anual varia de 1.100 a 1.400 $\mathrm{mm}$, e na região de foz ultrapassa o valor máximo anterior: $1.400 \mathrm{~mm}^{\mathrm{ano}}{ }^{-1}$.

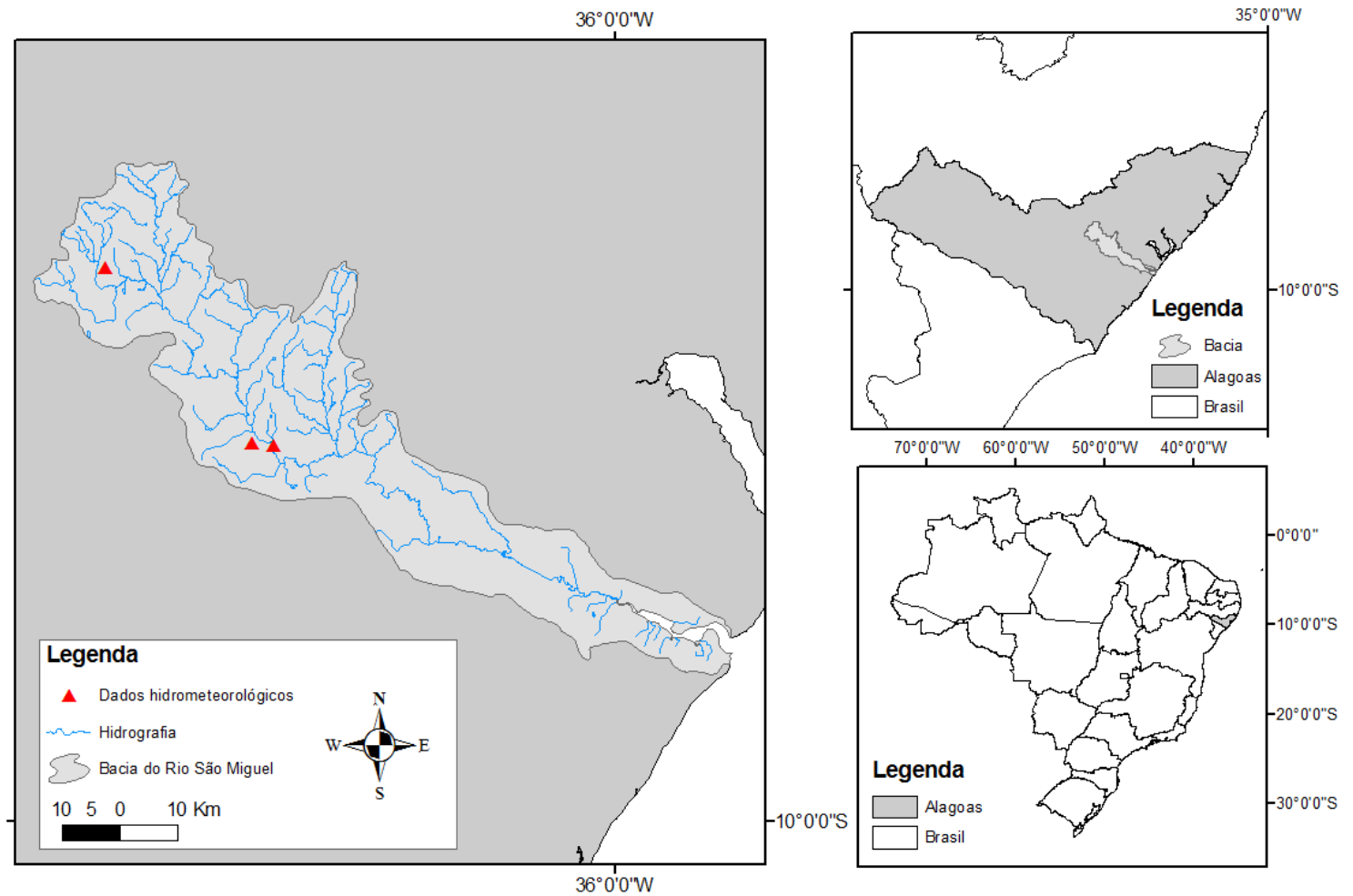

Figura 1. Localização da área de estudo.

\subsection{Dados pluviométricos e fluviométricos}

Para esse estudo foram utilizados dados de precipitação em escala diária, disponibilizados pela Secretaria de Estado de Meio Ambiente e Recursos Hídricos de Alagoas em www.semarh.al.gov.br e pela Agência Nacional de Águas em www.hidroweb.ana.gov.br.

Para o cálculo da precipitação média na bacia foi utilizado o método do polígono de Thiessen, conforme a Equação 1.

$$
\bar{P}=\frac{\sum P_{i} \cdot A_{i}}{A}
$$


em que:

$\mathrm{P}_{\mathrm{i}}$ : precipitações nos postos i $(\mathrm{mm})$;

$\mathrm{A}_{\mathrm{i}}$ : áreas de influência dos postos; e

A: área total da bacia.

Foram utilizados dados de uma estação fluviométrica da Agência Nacional de Águas (ANA) disponível em www.hidroweb.ana.gov.br, inserida na bacia hidrográfica do rio São Miguel para calibração e validação do modelo hidrológico.

A Tabela 1 apresenta os eventos hidrológicos selecionados para esse estudo, com destaque nas datas iniciais e finais dos eventos, assim como o tempo de duração e as vazões máximas dos eventos.

Tabela 1. Eventos hidrológicos selecionados.

\begin{tabular}{ccccc}
\hline Evento & $\begin{array}{c}\text { Data } \\
\text { Início }\end{array}$ & $\begin{array}{c}\text { Data } \\
\text { Fim }\end{array}$ & $\begin{array}{c}\text { Tempo } \\
\text { (horas) }\end{array}$ & $\begin{array}{c}\text { Vazão máxima } \\
\left(\mathrm{m}^{3} \mathrm{~s}^{-1}\right)\end{array}$ \\
\hline 1 & $02 / 05 / 14$ & $02 / 05 / 14$ & 6,0 & 43,07 \\
2 & $22 / 05 / 14$ & $23 / 05 / 14$ & 12,5 & 29,27 \\
3 & $07 / 08 / 14$ & $08 / 08 / 14$ & 16,0 & 70,06 \\
4 & $05 / 10 / 14$ & $07 / 10 / 14$ & 12,5 & 53,08 \\
5 & $28 / 06 / 15$ & $29 / 06 / 15$ & 12,0 & 37,72 \\
\hline
\end{tabular}

\subsection{Dados do RADAR}

Foram utilizados os dados do radar meteorológico do Centro Nacional de Monitoramento e Alertas de Desastres Naturais (CEMADEN) de Maceió/AL, localizado em $35.77^{\circ} \mathrm{W}$ e $9.55^{\circ} \mathrm{S}$, banda $\mathrm{S}$, doppler e de dupla polarização. Os pontos de grade do RADAR tem resolução espacial de $250 \mathrm{~m}$, que cobre a área da bacia com oito pontos.

A metodologia utilizada na obtenção da precipitação acumulada consiste em aplicar as variáveis polarimétricas $(\mathrm{Z}$ - refletividade horizontal [dBZ], $\mathrm{Zdr}$ - refletividade diferencial [dB] e Kdp - diferencial do deslocamento de fase $[\% / \mathrm{km}]$ ) conforme os limiares de taxa de precipitação (Equações 2, 3, 4, 5, e 6) para a obtenção da precipitação instantânea segundo a proposta por Ryzhkov et al. (2005). A cada varredura (10 minutos) é feita essa estimativa e os resultados são acumulados em períodos de 24-h. $\mathrm{R}(Z)$ é a relação de Marshall e Palmer (1948), onde $Z=a R b$, em que a e b são constantes iguais a 200 e 1.6, respectivamente.

$$
\mathrm{R}=\frac{\mathrm{R}(\mathrm{Z})}{0.4+5.0\left|\mathrm{Z}_{\mathrm{dr}}-1\right|^{1.3}}
$$

para $\mathrm{R}(\mathrm{Z})<6 \mathrm{~mm} \mathrm{~h}^{-1}$

$$
R=\frac{R\left(K_{d p}\right)}{0.4+3.5\left|Z_{d r}-1\right|^{1.7}}
$$

para $6<\mathrm{R}(\mathrm{Z})<50 \mathrm{~mm} \mathrm{~h}^{-1}$ 


$$
\mathrm{R}=\mathrm{R}\left(\mathrm{K}_{\mathrm{dp}}\right)
$$

para $\mathrm{R}(\mathrm{Z})>50 \mathrm{~mm} \mathrm{~h}^{-1}$

em que:

$$
\begin{aligned}
& \mathrm{R}(\mathrm{Z})=\frac{1}{a^{1 / b}} Z^{1 / b} \Leftrightarrow Z=a R^{b} \\
& \mathrm{R}\left(\mathrm{K}_{\mathrm{dp}}\right)=44.0\left|K_{d p}\right|^{0.822}
\end{aligned}
$$

para KDP $>0$

Uma calibração prévia da precipitação estimada por radar foi realizada utilizando dados das estações pluviométricas dentro da área de varredura quantitativa, seguindo os métodos de Brandes (1975) e Barnes (1964), onde foi detectada a priori uma subestimativa de 60\%, na média. Assim, esta correção foi aplicada nesse trabalho para alimentar o modelo hidrológico.

\subsection{Modelagem hidrológica: SCS-CN do HEC-HMS}

O HEC-HMS é um programa que pode ser adaptado a um sistema de interesse, através de mudanças nos dados em um banco de dados ou alterações nos parâmetros, nas condições de contorno e nas condições de entrada iniciais (Campos, 2009).

Para o cálculo do hietograma, utilizou-se o método dos blocos alternados. Na determinação da precipitação efetiva, aplicou-se o método da Curve Number $(\mathrm{CN})$, desenvolvido pelo Natural Resources Conservation Service (NRCS).

$\mathrm{O}$ valor de $\mathrm{CN}$ responde pela maior parte das características das bacias hidrográficas produtoras de escoamento, tais como tipo de solo, uso da terra, condição hidrológica e condição antecedente de umidade. (Mishra e Singh, 2004).

Para estimar a precipitação efetiva, aplicou-se a Equação 7:

$$
\mathrm{P}_{\mathrm{e}}=\frac{\left(\mathrm{P}-\mathrm{I}_{\mathrm{a}}\right)^{2}}{\mathrm{P}-\mathrm{I}_{\mathrm{a}}+\mathrm{S}} \text { para } \mathrm{P}>\text { Ia e } 0 \text { nos demais casos }
$$

em que:

$$
\begin{aligned}
& \mathrm{P}_{\mathrm{e}} \text { : é chuva efetiva }(\mathrm{mm}) ; \\
& \mathrm{P} \text { : é precipitação total }(\mathrm{mm}) ; \\
& \mathrm{I}_{\mathrm{a}} \text { : é abstração inicial }(\mathrm{mm}) ; \text { e } \\
& \mathrm{S} \text { : é máximo potencial de retenção do solo }(\mathrm{mm}) .
\end{aligned}
$$

Para Ia adotou-se o valor de 0,2S, conforme recomendado pelo NRCS. Assim, a Equação 7 pode ser reescrita na forma da Equação 8.

$$
\mathrm{P}_{\mathrm{e}}=\frac{(\mathrm{P}-0.2 \mathrm{~S})^{2}}{\mathrm{P}+0.8 \mathrm{~S}}
$$

em que:

S obtido pela Equação 9. 


$$
\mathrm{S}=\frac{(1000)}{\mathrm{CN}}-10
$$

$\mathrm{O}$ parâmetro $\mathrm{CN}$ está relacionado ao tipo de solo, ao tipo de cobertura vegetal e às condições de umidade antecedentes. Nesse estudo utilizou-se condição antecedente de umidade média para um solo tipo B com cobertura vegetal tipo: urbano, área vegetada e mata ciliar. Na estimativa do $\mathrm{CN}$, foram utilizadas imagens aéreas do município, combinadas com imagens do Google Earth. Destaca-se, que o valor do número $\mathrm{CN}$ foi estimado a partir dos valores da tabela determinada pelo NRCS, conforme o tipo de solo da área de estudo.

Para obter o hidrograma da cheia a partir do hietograma da chuva, aplicou-se o método do Hidrograma Unitário Adimensional do NRCS, seguindo a proposta de Ebrahimian et al. (2012). O método tem como parâmetro o tempo de retardo $\left(\mathrm{T}_{\mathrm{lag}}\right)$. $\mathrm{O}$ valor de $\mathrm{T}_{\mathrm{lag}}$ é obtido pela Equação 10.

$$
\mathrm{T}_{\text {lag }}=0.6 \mathrm{~T}_{\mathrm{c}}
$$

em que:

Tc: é tempo de concentração (min).

Para cálculo, o Tc é estimado pela Equação de Kirpich, Equação 11.

$$
\mathrm{T}_{\mathrm{c}}=0.0078 \mathrm{x}\left(\frac{\mathrm{L}^{0.77}}{\mathrm{~S}^{0.385}}\right)
$$

em que:

L: comprimento do rio $(\mathrm{km})$; e

S: declividade do rio $(\mathrm{m} / \mathrm{m})$.

A Tabela 2 apresenta algumas características fisiográficas (área da bacia, comprimento do rio, lag time, tempo de concentração, altitude e declividade média) obtidas através de técnicas de Sistema de Informações Geográficas (SIG) e programas computacionais.

Tabela 2. Característica fisiográfica da sub-bacia do rio São Miguel.

\begin{tabular}{ccccccc}
\hline Bacia & $\begin{array}{c}\text { Área } \\
\left(\mathrm{km}^{2}\right)\end{array}$ & $\begin{array}{c}\text { Comprimento } \\
\text { do rio }(\mathrm{km})\end{array}$ & $\begin{array}{c}\text { Lag Time } \\
(\mathrm{h})\end{array}$ & $\begin{array}{c}\text { Tempo de } \\
\text { Concentração }(\mathrm{h})\end{array}$ & $\begin{array}{c}\text { Altitude Média } \\
(\mathrm{m})\end{array}$ & $\begin{array}{c}\text { Declividade } \\
\text { Média }(\mathrm{m} / \mathrm{m})\end{array}$ \\
\hline São Miguel & 296 & 41 & 2,07 & 3,45 & 480 & 0,00978 \\
\hline
\end{tabular}

\subsection{Parametrização multi objetivo}

Foram escolhidos eventos registrados pelo posto fluviométrico para calibração e validação das vazões com as chuvas observadas como entrada. O procedimento de calibração automática do HEC-HMS utiliza um método iterativo para minimizar/maximizar uma função objetivo.

Para a calibração do SCS-CN foi escolhida uma função objetivo baseada no erro percentual do pico (Equação 12), essa medida só considera a magnitude de computação total do pico do evento. 


$$
Z=\sum_{i=1}^{N Q}\left|\frac{q_{0}(\text { pico })-q_{s}(\text { pico })}{q_{0}(\text { pico })}\right|
$$

em que:

Z: é função objetiva;

NQ: são números de ordenadas do hidrogramas calculadas;

Qo $(\mathrm{t})$ : é vazão observada;

$\mathrm{Q}_{\mathrm{s}}(\mathrm{t})$ : são vazões calculadas com os parâmetros do modelo;

qo (pico): é pico observado;

qo (média): é média das vazões; e

$\mathrm{q}_{\mathrm{s}}$ (pico): é pico calculado.

\subsection{Análise da eficiência da modelagem hidrológica}

Para determinação da eficiência da modelagem foi utilizado o coeficiente de Nash-Sutcliffe (1970) que tem sido largamente utilizado na verificação do desempenho de modelos hidrológicos. O coeficiente NS pode ser dado pela seguinte Equação 13.

$$
N S=1-\frac{\sum_{t=1}^{n t}\left[Q_{o b s}(t)-Q_{\text {sim }}(t)\right]^{2}}{\sum_{t=1}^{n t}\left[Q_{o b s}(t)-\bar{Q}_{o b s}(t)\right]^{2}}
$$

em que:

$\mathrm{Q}_{\text {obs }}(\mathrm{t})$ : vazão observada no passo de tempo $\mathrm{t}$ em $\left(\mathrm{m}^{3} \mathrm{~s}^{-1}\right)$;

$\mathrm{Q}_{\text {sim }}(\mathrm{t})$ : vazão simulada em $\left(\mathrm{m}^{3} \mathrm{~s}^{-1}\right)$; e

Q obs: média de vazões observadas de todo o período de simulação em $\left(\mathrm{m}^{3} \mathrm{~s}^{-1}\right)$.

\section{RESULTADOS E DISCUSSÃO}

\subsection{Análises das vazões}

A Tabela 3 mostra o desempenho da estimativa das vazões usando o SCS-CN na fase de calibração e validação, com as precipitações observadas e estimadas com RADAR para os eventos selecionados, conforme a descrição dos eventos hidrológicos na Tabela 1. Nessa fase a modelagem hidrológica apresentou valores $\mathrm{NS}=0,93$ para o período da calibração.

Moriasi et al. (2007) destacam que os limites aceitáveis dos critérios de avaliação da calibração de modelos hidrológicos devem ser menos exigentes para simulações com passo de tempo diário. Segundo Collischonn (2001), valores de Nash-Sutcliffe > 0,75, como os encontrados nesse estudo, são considerados adequados.

Para os eventos hidrológicos 2, 3, 4 e 5, o modelo SCS-CN do HEC-HMS apresentou desempenho satisfatório, com valores de Nash-Sutcliffe entre 0,87 a 0,81 para vazões com a precipitação observada, e Nash-Sutcliffe entre 0,75 a 0,79 para vazões com estimativa de chuva do RADAR de Maceió-AL. 
Tabela 3. Eficiência da calibração dos parâmetros do SCS-CN.

\begin{tabular}{ccccc}
\hline Evento & $\begin{array}{c}\text { Períodos } \\
\text { (horas) }\end{array}$ & Fase & $\mathrm{Q}\left(\mathrm{P}_{\mathrm{obs}}\right)$ & $\mathrm{Q}\left(\mathrm{P}_{\text {RADAR }}\right)$ \\
\hline 1 & 6,0 & Calibração & 0,90 & - \\
2 & 12,5 & Validação & 0,87 & 0,79 \\
3 & 16,0 & Validação & 0,81 & 0,77 \\
4 & 12,5 & Validação & 0,83 & 0,75 \\
5 & 12,0 & Validação & 0,86 & 0,78 \\
\hline
\end{tabular}

A Figura 2 apresenta o hidrograma das vazões observadas e simuladas pelo SCS-CN do HEC-HMS, e o hietograma da precipitação média observada na bacia hidrográfica para o evento hidrológico utilizado na fase de calibração, verificando assim a eficiência da calibração do modelo. O SCS-CN mostrou boa consistência na parametrização e uma representação eficiente dos processos de propagação pelo modelo. Nota-se que o hidrograma ajustou-se bem tanto à vazão de pico quanto no período de recessão para todo o evento. Isso pode estar associado principalmente a função objetiva escolhida na parametrização dos parâmetros do modelo hidrológico. Nota-se que o modelo subestima as vazões no início do evento até vazões da ordem de $15 \mathrm{~m}^{3} \mathrm{~s}^{-1}$; já com valores maiores que $15 \mathrm{~m}^{3} \mathrm{~s}^{-1}$ o modelo tende a subestimar essas vazões. Entretanto de maneira geral o modelo representou de forma satisfatória as vazões, com valor de NS $=0,90$.

Segundo Sene (2012), algumas incertezas e erros podem está associadas a problemas nos dados pluviométricos, tais como: medição, obstrução ou falta de manutenção, bem como a imprecisão na distribuição espacial da precipitação ao longo da bacia hidrográfica.

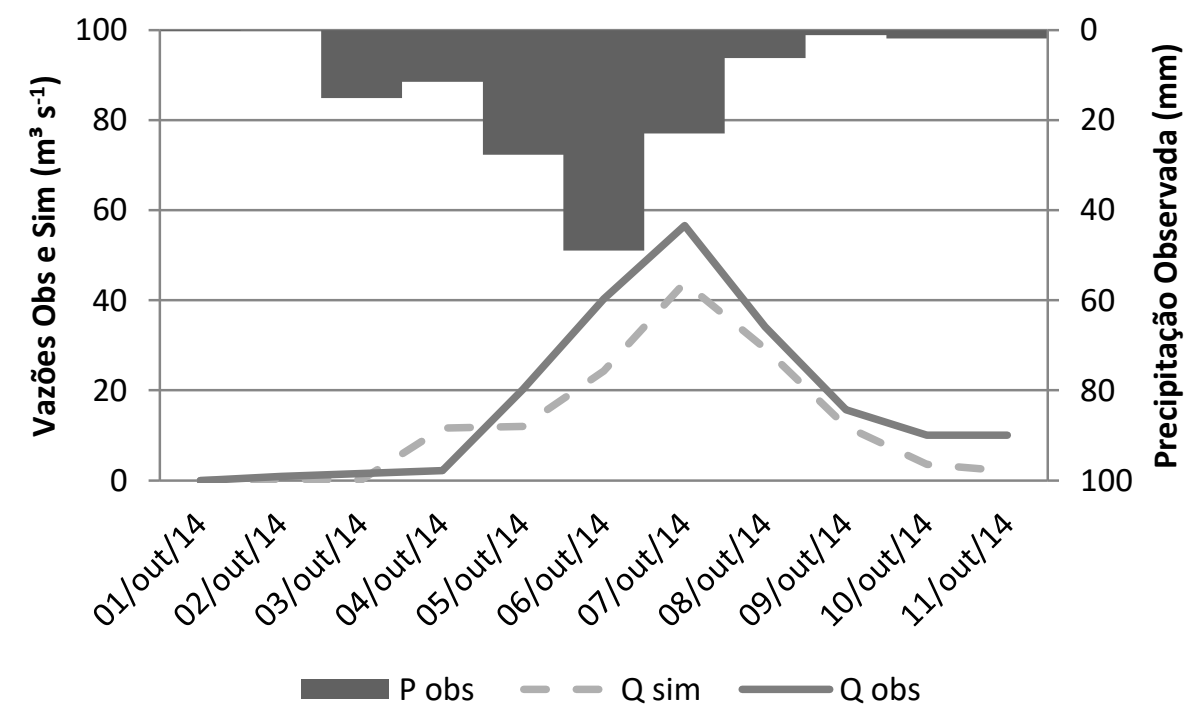

Figura 2. Hidrograma da vazão simulada e observada, e hietograma da precipitação observada.

A Figura 3 apresenta os hidrogramas das vazões observadas e simuladas pelo SCS-CN do HEC-HMS, com dados do RADAR na bacia hidrográfica do rio São Miguel, para os 
eventos hidrológicos (2(a), 3(b), 4(c) e 5(d)). O SCS-CN mostrou desempenho satisfatório para as vazões, com os dados de entrada de precipitação calibrados do RADAR de Maceió AL. O modelo conseguiu representar bem as curvas das vazões, entretanto não conseguiu representar as vazões do pico dos eventos, apresentando erros da ordem de até $26 \%$. Todavia, os resultados demonstram ser útil na representação de eventos de extremos hidrológicos na região.

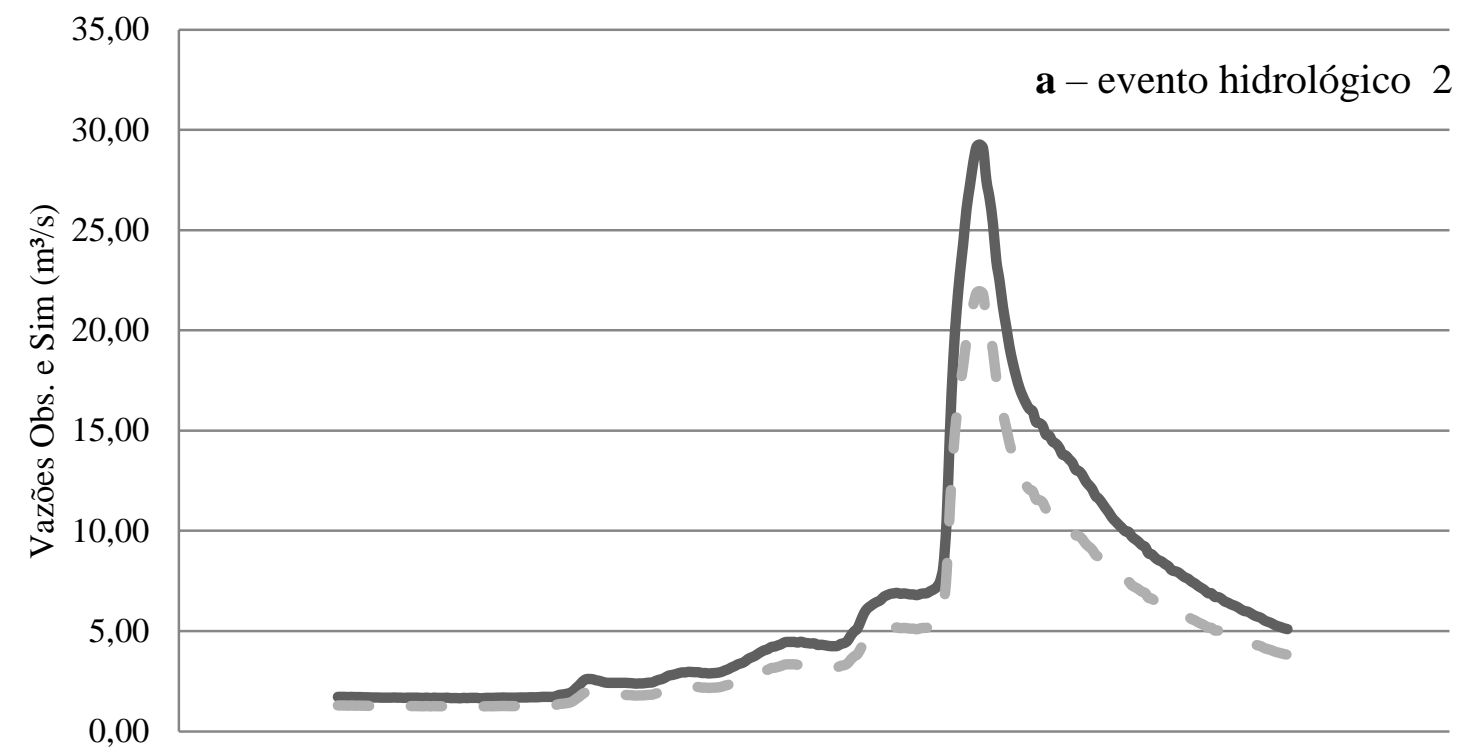

20/05/2014 21/05/2014 21/05/2014 22/05/2014 22/05/2014 23/05/2014 23/05/2014 24/05/2014 24/05/2014 Tempo (dias)

$\longrightarrow$ Vazão Obs $\left(\mathrm{m}^{3} / \mathrm{s}\right) \longrightarrow$ Vazão Sim RADAR $\left(\mathrm{m}^{3} / \mathrm{s}\right)$

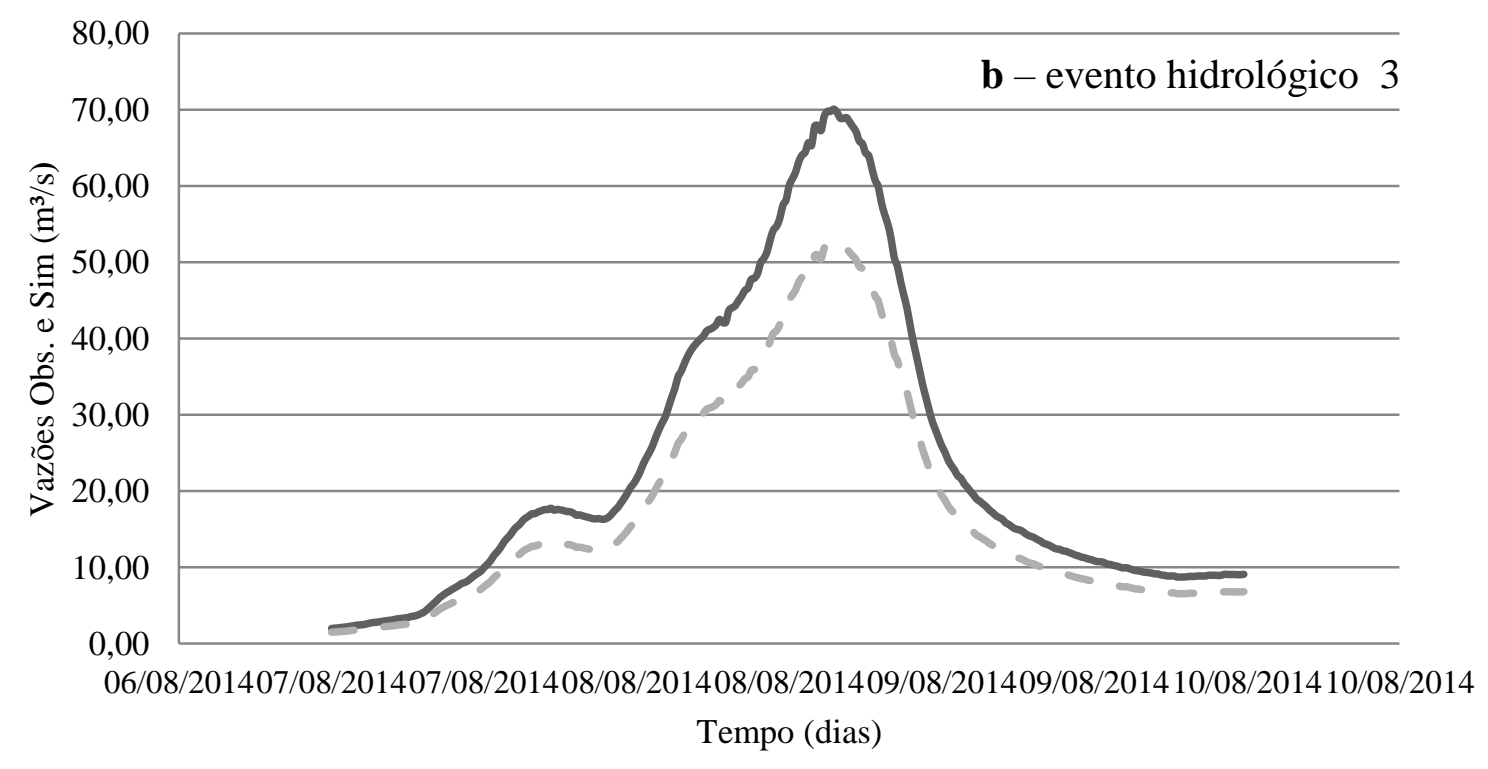

Vazão Obs $\left(\mathrm{m}^{3} / \mathrm{s}\right) \quad-$ Vazão $\operatorname{Sim} \operatorname{RADAR}\left(\mathrm{m}^{3} / \mathrm{s}\right)$ 


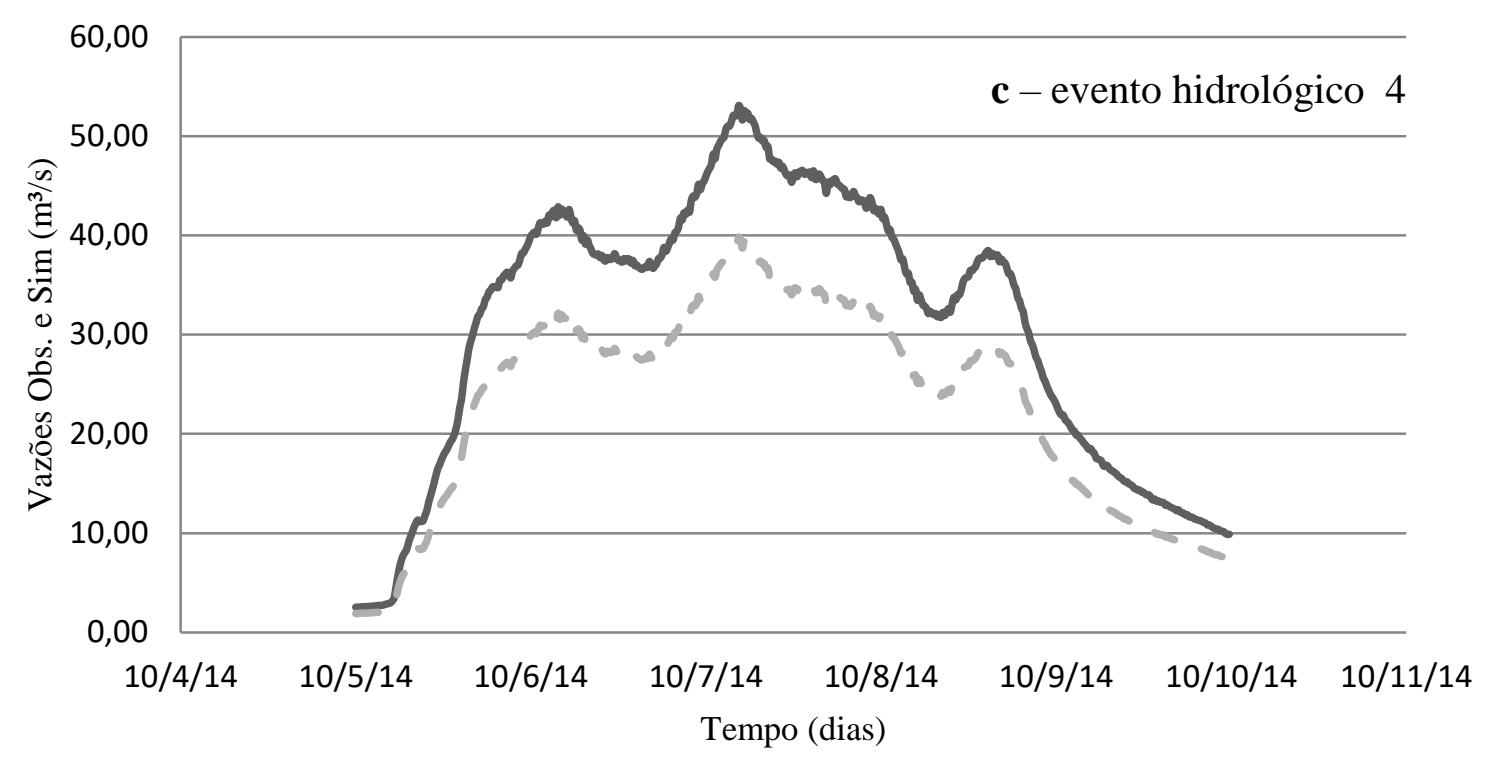

$\longrightarrow$ Vazão Obs $\left(\mathrm{m}^{3} / \mathrm{s}\right) \quad-$ Vazão $\operatorname{Sim} \operatorname{RADAR}\left(\mathrm{m}^{3} / \mathrm{s}\right)$

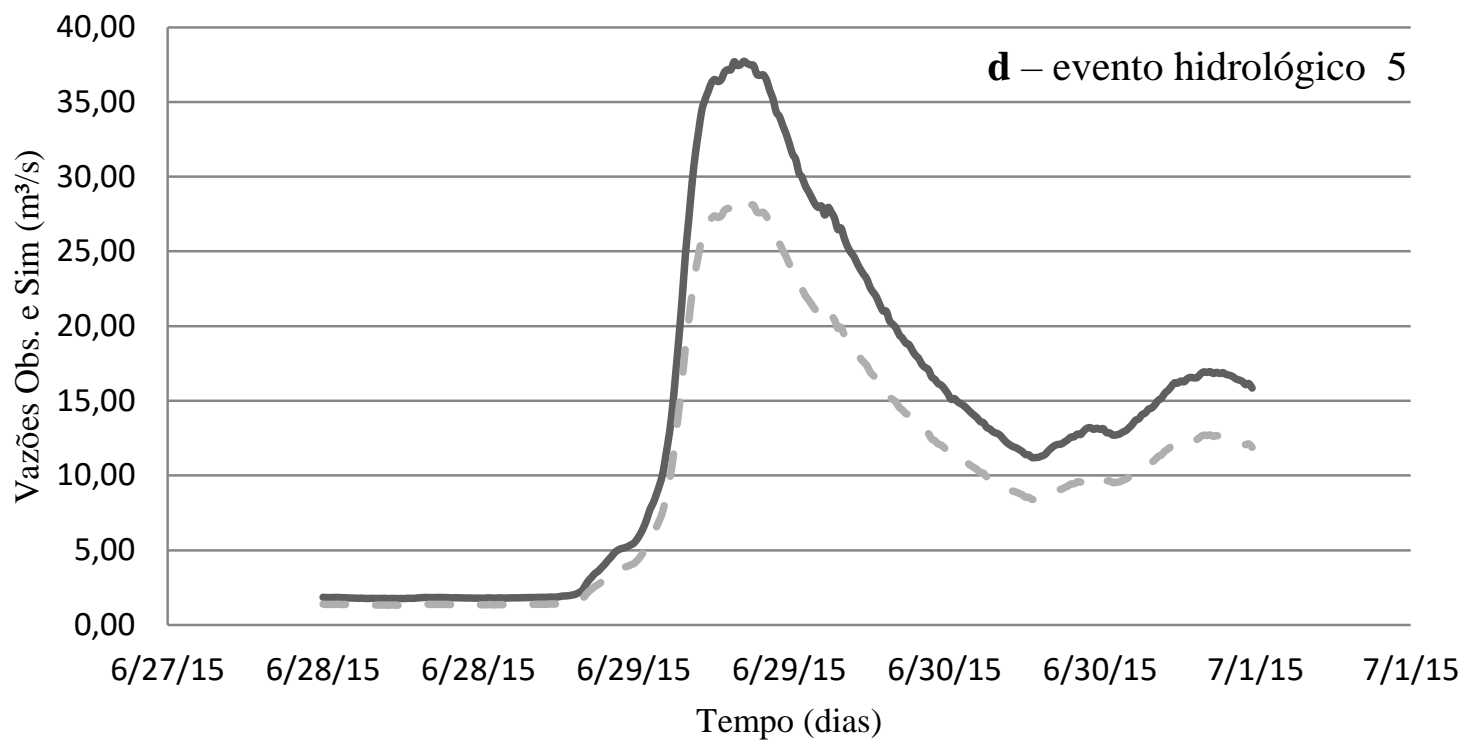

$\longrightarrow$ Vazão Obs $\left(\mathrm{m}^{3} / \mathrm{s}\right) \quad-$ Vazão $\operatorname{Sim} \operatorname{RADAR}\left(\mathrm{m}^{3} / \mathrm{s}\right)$

Figura 3. Hidrogramas das vazões simuladas e observadas nos eventos hidrológicos 2, 3, 4, e 5.

Verifica-se um desempenho superior, comparando com outros estudos que utilizaram o modelo HEC-HMS, (De Silva et al., 2014; Haberlandt e Radtke, 2014). Entretanto, em uma avaliação de três modelos hidrológicos na bacia hidrográfica do rio Una, no NEB, Carvalho Neto, Ribeiro Neto e Montenegro (2014) observaram desempenho semelhante entre o modelo HEC-HMS, um modelo concentrado (MODHAC) e um modelo distribuído por células (MGB-IPH).

A Tabela 4 mostra as análises do tempo do pico, das vazões de pico e o volume total com informações das simulações do SCS-CN para precipitação observada e pelo RADAR. Os tempos de pico das vazões máximas calculadas foram iguais aos observados para todos os casos. Embora o SCS-CN do HEC-HMS tenha conseguido acompanhar as vazões de pico dos 
eventos, tanto com as precipitações observadas como com as precipitações estimadas pelo RADAR, o modelo subestimou os valores de pico em todos os eventos simulados, com erros variando entre $3 \%$ a $26 \%$ para os eventos simulados. Os volumes estimados pelo modelo SCS-CN apresentaram erros para todos os eventos, com erros menores para a simulação usando precipitações observadas $(9,49 \%)$, e erros mais significativos para estimativas de precipitações por RADAR (40,87\%). Esses erros podem esta relacionados à distribuição espacial da precipitação observada e/ou à subestimação da precipitação por RADAR. Entretanto o método mostrou valores considerados satisfatórios, levando em consideração a limitação da base de dados observados e a qualidade dos dados na bacia hidrográfica.

Tabela 4. Análise das estimativas das vazões com precipitações observadas e do RADAR.

\begin{tabular}{|c|c|c|c|c|c|c|}
\hline \multirow{4}{*}{$\begin{array}{l}\overrightarrow{0} \\
\stackrel{0}{0} \\
\text { 齐 }\end{array}$} & & $\begin{array}{l}\text { Tempo do } \\
\text { pico }\end{array}$ & $\begin{array}{l}Q_{\text {pico }} \\
\left(\mathrm{m}^{3} \mathrm{~s}^{-1}\right)\end{array}$ & $\begin{array}{l}\text { Erro } Q_{\text {pico }} \\
\quad(\%)\end{array}$ & $\begin{array}{c}\text { Volume } \\
\text { (mm) }\end{array}$ & $\begin{array}{c}\text { Erro Volume } \\
\qquad(\%)\end{array}$ \\
\hline & $Q_{\text {obs }}$ & $02 / 05 / 14$ & 43,07 & - & 44,22 & - \\
\hline & $\operatorname{Sim}_{\text {(Pobs) }}$ & $02 / 05 / 14$ & 38,23 & 10,77 & 39,87 & 9,83 \\
\hline & $\begin{array}{c}\text { Sim } \\
\text { (RADAR) }\end{array}$ & $02 / 05 / 14$ & - & - & - & - \\
\hline \multirow{3}{*}{ 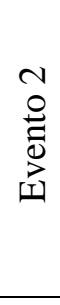 } & $Q_{\text {obs }}$ & $22 / 05 / 14$ & 29,27 & - & 31,18 & - \\
\hline & $\operatorname{Sim}_{(\mathrm{Pobs})}$ & $22 / 05 / 14$ & 26,55 & 9,29 & 28,22 & 9,49 \\
\hline & $\begin{array}{c}\text { Sim } \\
\text { (RADAR) }\end{array}$ & $22 / 05 / 14$ & 21,88 & 25,24 & 25,85 & 17,09 \\
\hline \multirow{3}{*}{$\begin{array}{l}m \\
\stackrel{0}{0} \\
\stackrel{0}{0} \\
\stackrel{2}{1} \\
0\end{array}$} & $Q_{\text {obs }}$ & 07/08/14 & 70,06 & - & 82,25 & - \\
\hline & $\operatorname{Sim}_{(\mathrm{Pobs})}$ & 07/08/14 & 67,33 & 3,89 & 75,39 & 8,34 \\
\hline & $\begin{array}{c}\text { Sim } \\
\text { (RADAR) }\end{array}$ & 07/08/14 & 52,54 & 25,0 & 64,37 & 21,73 \\
\hline \multirow{3}{*}{$\begin{array}{l}+ \\
\stackrel{0}{0} \\
\stackrel{0}{0} \\
\stackrel{D}{ \pm}\end{array}$} & $Q_{\text {obs }}$ & 05/10/14 & 53,08 & - & 54,43 & - \\
\hline & $\operatorname{Sim}_{(\mathrm{Pobs})}$ & $05 / 10 / 14$ & 43,90 & 17,29 & 40,26 & 26,03 \\
\hline & $\begin{array}{c}\mathrm{Sim} \\
\text { (RADAR) }\end{array}$ & 05/10/14 & 39,0 & 26,0 & 32,18 & 40,87 \\
\hline \multirow{3}{*}{$\begin{array}{l}n \\
\stackrel{0}{0} \\
\stackrel{0}{0} \\
\stackrel{1}{1}\end{array}$} & $Q_{\text {obs }}$ & $28 / 06 / 15$ & 37,72 & - & 41,16 & - \\
\hline & $\operatorname{Sim}_{\text {(Pobs) }}$ & $28 / 06 / 15$ & 34,85 & 7,60 & 39,12 & 6,09 \\
\hline & $\underset{(\operatorname{RADAR})}{\mathrm{Sim}}$ & $28 / 06 / 15$ & 28,29 & 25,0 & 35,82 & 14,01 \\
\hline
\end{tabular}

\section{IPABH}




\section{CONCLUSÃO}

A calibração e validação dos parâmetros do SCS-CN do HEC-HMS mostrou bom desempenho, validando o uso do modelo hidrológico na região de estudo. O SCS-CN mostrou um bom ajuste nas vazões simuladas para os eventos hidrológicos com as duas formas de precipitação (observada e RADAR), como dado de entrada no modelo.

O modelo hidrológico conseguiu demonstrar de forma satisfatória os eventos hidrológicos usando dados de RADAR, mesmo subestimando a magnitude das vazões de pico. O modelo representou de forma satisfatória a tendência das vazões, mostrando ser uma ferramenta que pode oferecer subsídios a fim de mitigar eventos extremos de caráter hidrológico na região.

Por fim, o presente trabalho poderá contribuir para melhorar o desempenho de modelos hidrológicos e auxiliar os sistemas de alerta a inundações, podendo ainda aplicar a correção da chuva para outras áreas de cobertura do radar, e assim, utilizar essa informação quantitativa em modelos hidrológicos, e também para diversas outras áreas onde se apresentam grandes carências por informações de precipitação com boa distribuição espacial e temporal.

\section{REFERENCIAS}

BARNES, S. L. A technique for maximizing details in numerical weather map analysis. Journal of Applied Meteorology, v. 3, p. 396-409, 1964. http://dx.doi.org/ 10.1175/1520-0450(1964)003\%3C0396:ATFMDI\%3E2.0.CO;2

BRANDES, E. A. Optimizing rainfall estimates with the aid of radar. Journal of Applied Meteorology, v. 14, p. 1339-1345, 1975. http://dx.doi.org/10.1175/15200450(1975)014<1339:OREWTA>2.0.CO;2

BECK, M. B. Water Quality modeling: a review of the analysis of uncertainty.Water Resources Research, v. 23, n. 8, p. 1393-1442, 1987. http://dx.doi.org/ 10.1029/WR023i008p01393

CABRAL, S. L.; CAMPOS, J. N. B.; SILVEIRA, C. S.; RODRIGUES, J. M. O intervalo de tempo para uma máxima previsibilidade da precipitação sobre o Semiárido brasileiro. Revista Brasileira de Meteorologia, v. 31, n. 2, 2016. http://dx.doi.org/10.1590/0102778631220130034

CAMPOS, J. N. B. Lições em modelos e simulação hidrológica. Fortaleza: ASTEF/Expressão Gráfica, 2009. v. 1. 166 p.

CARVALHO NETO, J. G.; RIBEIRO NETO, A.; MONTENEGRO, S. M. G. L. Assessment of RainfallRunoff Models for Flood River Extreme Event Simulations. In: INTERNATIONAL CONFERENCE ON FLOOD MANAGEMENT, 6., 2014, São Paulo. Anais... São Paulo; [s.n.], 2014.

COLLISCHONN, W. Simulação hidrológica em grandes bacias. 2001. 194f. Tese (Doutorado em Engenharia Civil) - Universidade Federal do Rio Grande do Sul, Porto Alegre, 2001.

DE SILVA, M. M. G. T.; WEERAKOON, S. B.; HERATH, S. Modeling of Event and Continuous Flow Hydrographs with HEC-HMS: Case Study in the Kelani River Basin, Sri Lanka. Journal of Hydrologic Engineering, v. 19, n. 4, p. 800-806, 2014. http://dx.doi.org/10.1061/(ASCE)HE.1943-5584.0000846 
GONÇALVES, F. M. Utilização de radar meteorológico em hidrologia. 2005. $116 f$. Dissertação (Mestrado em Engenharia) - Escola Politécnica da Universidade de São Paulo, São Paulo,2005.

HABERLANDT, U.; RADTKE, I. Hydrological model calibration for derived flood frequency analysis using stochastic rainfall and probability distributions of peak flows.

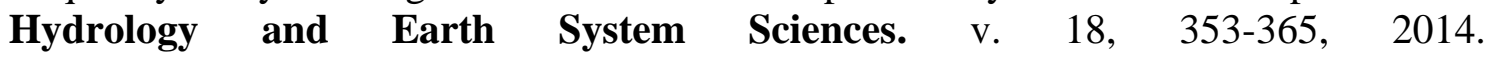
http://dx.doi.org/10.5194/hess-18-353-2014

HOSSAIN, F.; ANAGNOSTOU, E. N. Assessment of current passive-microwaveand infrared-based satellite rainfall remote sensing for flood prediction. Journal of Geophysical Research: Atmospheres, v. 109, n. D7, 2004. http://dx.doi.org/10.1029/2003JD003986

HOSSAIN, F.; ANAGNOSTOU, E. N.; DINKU, T.; BORGA, M. Hydrological model sensitivity to parameter and radar rainfall estimation uncertainty. Hydrological Processes, v. 18, n. 17, p. 3277-3291, 2004. http://dx.doi.org/10.1002/hyp.5659

KAVETSKI, D.; KUCZERA, G.; FRANKS, S. W. Bayesian analysis of input uncertainty in hydrological modeling: 1. theory. Water Resources Research, v. 42, n. 3, 2006. http://dx.doi.org/10.1029/2005WR004376

KAVETSKI, D.; KUCZERA, G.; FRANKS, S. W. Bayesian analysis of input uncertainty in hydrological modeling: 2. application. Water Resources Research, v. 42, n. 3, 2006. http://dx.doi.org/10.1029/2005WR004376

KRZYSZTOFOWICZ, R. Bayesian theory of probabilistic forecasting via deterministic hydrologic model. Water Resources Research, v. 35, n. 9, p. 2739-2750, 1999. 10.1029/1999WR900099

KRZYSZTOFOWICZ, R. The case for probabilistic forecasting in hydrology. Journal of Hydrology, v. 249, p. 2-9, 2001. http://dx.doi.org/10.1016/S0022-1694(01)00420-6

MARSHALL, J. S.; PALMER, W. Mc K. The distribution of raindrops with size. Journal of Meteorology, v. 5, p. 165-166, 1948. http://dx.doi.org/10.1175/15200469(1948)005\%3C0165:TDORWS\%3E2.0.CO;2

MCINTYRE, N.; WHEATER, H. S. Calibration of an in-river phosphorus model: prior evaluation of data needs and model uncertainty. Journal of Hydrology, v. 290, p. 100116, 2004. http://dx.doi.org/10.1016/j.jhydrol.2003.12.003

MISHRA, S. K.; SINGH, V. P. Long-term hydrological simulation based on the Soil Conservation Service curve number. Hydrological Processes, v. 18, p. 1291-1313. http://dx.doi.org/10.1002/hyp.1344

MORIASI, D. N.; ARNOLD, J. G.; VANLIEW, M. W.; BINGNER, R. L.; HARMEL, R. D. VEITH, T. L. Model evaluation guidelines for systematic quantification of accuracy in watershed simulations. Transactions of the ASABE, v. 50, n. 3, p. 885-900, 2007. $10.13031 / 2013.23153$

MULETA, M. K.; NICKLOW, J. W. Sensitivity and uncertainty analysis coupled with automatic calibration for a distributed watershed model. Journal of Hydrology, v. 306, p. 127-145, 2005. http://dx.doi.org/10.1016/j.jhydrol.2004.09.005 
NIKOLOPOULOS, E. I.; ANAGNOSTOU, E. N.; HOSSAIN, F.; GEBREMICHAEL, M.; BORGA, M. Understanding the scale relationships of uncertainty propagation of satellite rainfall through a distributed hydrologic model. Journal of Hydrometeorology, American Meteorological Society, v. 11, n. 2, p. 520-532, 2010. http://dx.doi.org/10.1175/2009JHM1169.1

ORESKES, N.; SHRADER-FRECHETTE, K.; BELITZ, K. Verification. validation and confirmation of numerical models in the earth sciences. Science, v. 263, p. 641-646, 1994.

RYZHKOV, A. V.; GIANGRANDE, S. E.; SCHUUR, T. J. Rainfall estimation with a polarimetric prototype of WSR-88D. Journal Applied Meteorology, v. 44, p. 502-515, 2005. http://dx.doi.org/10.1175/JAM2213.1

SENE, K. Flash Floods- Forecasting and Warning. Dordrecht: Springer, 2012.168p. 


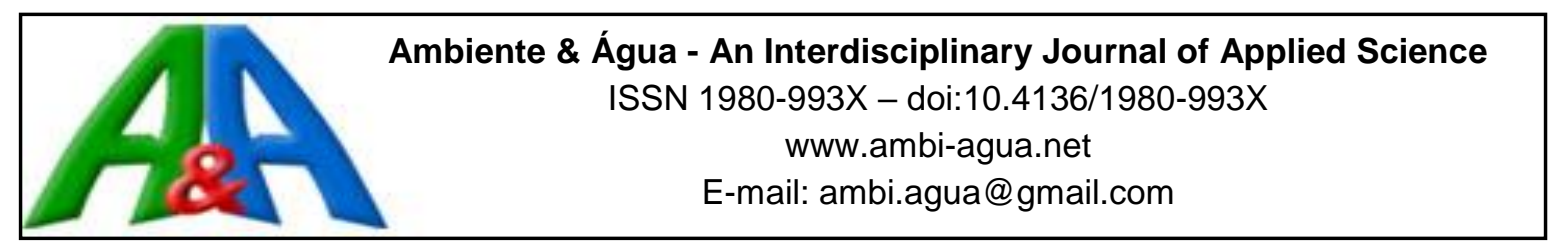

\title{
Crescimento foliar e atividades das enzimas antioxidativas em plântulas de girassol suplementadas com percolado de aterro sanitário e submetidas a estresse hídrico
}

\author{
doi:10.4136/ambi-agua.1964
}

Received: 30 Jun. 2016; Accepted: 26 Oct. 2016

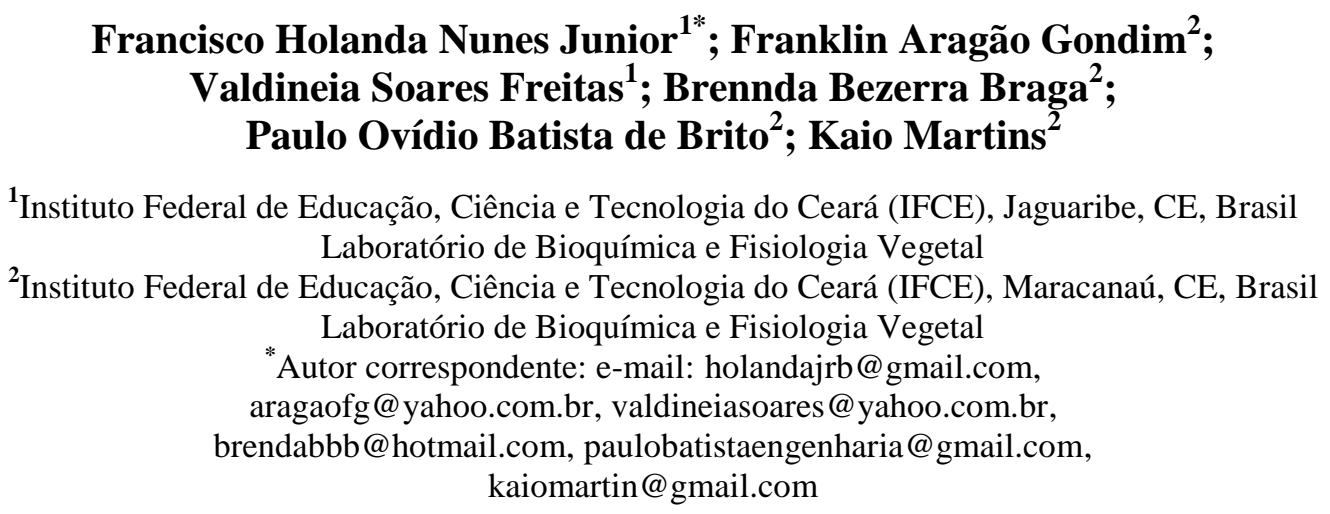

\section{RESUMO}

Em regiões áridas ou semiáridas, a escassez hídrica tem sido um dos principais fatores limitantes da produção agrícola. Diante disso, o presente trabalho objetivou analisar os efeitos da aplicação de percolado de aterro sanitário no crescimento foliar (número de folhas e área foliar) e as atividades das enzimas antioxidativas: superóxido dismutase (SOD), catalase (CAT), peroxidase do ascorbato (APX) e peroxidase do guaiacol (GPX) em folhas e raízes de plântulas de girassol submetidas às condições de estresse hídrico. $O$ delineamento experimental foi o inteiramente casualizado, disposto em arranjo fatorial dois (irrigadas ou não irrigadas) x quatro (areia; areia + adubo orgânico $100 \mathrm{~kg} \mathrm{~N} \mathrm{ha}^{-1}$; areia + percolado de aterro sanitário $100 \mathrm{~kg} \mathrm{~N} \mathrm{ha}^{-1}$; areia + percolado de aterro sanitário $150 \mathrm{~kg} \mathrm{~N}$ ha $^{-1}$ ), com cinco repetições. Em relação aos parâmetros foliares, o tratamento $100 \mathrm{~kg} \mathrm{~N} \mathrm{ha}^{-1}$ suplementado com percolado de aterro sanitário obteve os melhores incrementos no número de folhas e área foliar. Além disso, verificaram-se aumentos nas atividades das enzimas antioxidativas em folhas e raízes de plântulas de girassol suplementadas com percolado de aterro sanitário, sendo provável que as reduções dos efeitos deletérios do estresse hídrico nas variáveis foliares dos tratamentos suplementados com percolado de aterro sanitário tenham ocorrido em virtude das maiores atividades das enzimas antioxidativas, especialmente as da CAT nas folhas e GPX nas raízes.

Palavras-chave: chorume, estresse oxidativo, Helianthus annuus L, seca.

\section{Leaf growth and antioxidative enzyme activities in sunflower seedlings supplemented by sanitary landfill leachate under drought stress}

\section{ABSTRACT}

In arid or semi-arid regions, the limited availability of water resources has been one the main limiting factors in agricultural production. We analyzed the effects of the application of 
sanitary landfill leachate on the growth of leaves (number of leaves and leaf area) and the activities of the antioxidative enzymes superoxide dismutase (SOD), catalase (CAT), ascorbate peroxidase (APX) and guaiacol peroxidase (GPX) in the leaves and roots of sunflower seedling subjected to drought stress. The experimental design was completely randomized in a factorial two (irrigated and non-irrigated) $\mathrm{x}$ four (sand; sand + organic fertilizer $100 \mathrm{~kg} \mathrm{~N} \mathrm{ha}^{-1}$; sand + sanitary landfill leachate $100 \mathrm{~kg} \mathrm{~N} \mathrm{ha}^{-1}$; sand + sanitary landfill leachate $150 \mathrm{~kg} \mathrm{~N} \mathrm{ha}^{-1}$ ) with five replicates. In relation to foliar growth, the treatment $100 \mathrm{~kg} \mathrm{~N} \mathrm{ha}^{-1}$ supplemented by sanitary landfill leachate increased the number of leaves and leaf area. In addition, there were increases in the antioxidative enzymes' activities in leaves and roots of sunflower seedlings supplemented by sanitary landfill leachate. Thus, it is possible that the reductions in harmful effects of drought stress on the leaves' growth in treatments supplemented by sanitary landfill leachate occurred due to increased antioxidative enzymes activities, especially CAT in leaves and GPX in roots.

Keywords: chorume, drought, Helianthus annuus L., oxidative stress.

\section{INTRODUÇÃO}

A seca é um dos principais fatores limitantes da produção agrícola nas regiões áridas e semiáridas. Nesses ambientes, as plantas podem enfrentar situações de déficit hídrico devido à limitada disponibilidade de água no ambiente radicular, ou quando a taxa evapotranspiratória torna-se excessiva (Ghobadi et al., 2013).

De modo geral, as plantas tendem a fechar seus estômatos como resposta inicial ao déficit hídrico, a fim de reduzir a taxa de transpiração. Consequentemente, a taxa fotossintética é reduzida devido à menor disponibilidade de $\mathrm{CO}_{2}$, podendo ocorrer aumento da respiração. A baixa concentração de $\mathrm{CO}_{2}$ na etapa bioquímica da fotossíntese reduz a oxidação de NADPH no ciclo de Calvin-Benson, e, consequentemente, sua disponibilidade sob a forma de $\mathrm{NADP}^{+}$na etapa fotoquímica. Assim, este processo poderá resultar na transferência de elétrons da ferredoxina reduzida no fotossistema $\mathrm{I}$ ao $\mathrm{O}_{2}$, e aumentar a produção de espécies reativas de oxigênio ROS (do inglês Reactive Oxigen Species), com danos ao aparato fotossintético e estresse oxidativo (Pereira et al., 2012; Ghobadi et al., 2013; Cerqueira et al., 2015).

As ROS são produzidas naturalmente através do metabolismo celular de organelas como as mitocôndrias, cloroplastos e peroxissomos (Karuppanapandian et al., 2011), sendo produzidos o oxigênio singleto $\left({ }^{1} \mathrm{O}_{2}\right)$, o radical superóxido $\left({ }^{\circ} \mathrm{O}_{2}{ }^{-}\right)$e hidroxil $\left({ }^{\circ} \mathrm{OH}\right)$ e o peróxido de hidrogênio $\left(\mathrm{H}_{2} \mathrm{O}_{2}\right)$ (Sharma et al., 2012).

Ainda não está totalmente elucidado o papel da produção e controle das concentrações de ROS durante o estresse hídrico em plantas. De maneira geral, os estresses abióticos estão associados à produção de ROS, sendo, em baixas concentrações, necessários como sinalizadores do processo de aclimatação das plantas (Ren et al., 2016). No entanto, quando há um desequilíbrio entre produção e eliminação, desencadeiam-se danos às proteínas e aos ácidos nucleicos, além da peroxidação de lipídios de membrana, podendo levar as células do organismo à morte (Miller et al., 2010).

Diante disso, as plantas desenvolveram mecanismos enzimáticos e não enzimáticos (antioxidantes de baixos pesos moleculares) de defesa, capazes de eliminar os efeitos citotóxicos das ROS. No sistema enzimático, destacam-se: a superóxido dismutase (SOD), a catalase (CAT), a peroxidase do ascorbato (APX), bem como peroxidases não específicas quanto ao doador de elétrons, como a peroxidase do guaiacol (GPX). Estas enzimas atuam conjuntamente na eliminação das ROS (Deuner et al., 2008; Barbosa et al., 2014).

A enzima SOD atua na conversão do radical superóxido $\left({ }^{\circ} \mathrm{O}_{2}{ }^{-}\right)$a peróxido de hidrogênio 
$\left(\mathrm{H}_{2} \mathrm{O}_{2}\right)$ e oxigênio $\left(\mathrm{O}_{2}\right) . \mathrm{O} \mathrm{H}_{2} \mathrm{O}_{2}$ por sua vez, devido à sua toxicidade, é dismutado em $\mathrm{H}_{2} \mathrm{O}$ e $\mathrm{O}_{2}$ pelas enzimas CAT, APX e GPX, a fim de diminuir os efeitos citotóxicos no vegetal (Shehab et al., 2010).

No nordeste brasileiro, em virtude dos grandes períodos de estiagem, a água é o principal fator limitante para a produção agrícola, seguido pela baixa fertilidade de seus solos (Xavier et al., 2014). O uso de efluentes pode se tornar uma opção para reduzir o uso de águas com qualidades superiores na irrigação e gastos com fertilizantes. Adicionalmente, ressaltam-se como vantagens: o controle da poluição ambiental, a reciclagem de nutrientes e o aumento da produção agrícola (Silva et al., 2011).

Proveniente da decomposição dos resíduos sólidos dispostos nos aterros sanitários, o percolado é um efluente de variada composição físico-química, destacando-se a presença de matéria orgânica, macro e micronutrientes inorgânicos que possibilitam sua utilização como fonte de nutrientes e água no cultivo de plantas (Canto et al., 2013; Coelho et al., 2015).

Originário da América do Norte, o girassol (Helianthus annuus L.) é uma planta tolerante à seca e à salinidade (NSA, 2010). Seu cultivo tem sido feito principalmente para a extração de óleo, estando a cultura entre as quatro principais produtoras do mundo (FAO, 2013). Adicionalmente, a planta vem sendo considerada como uma das espécies de maior potencial para produção de biocombustíveis, sendo também bastante empregada em sistemas de sucessão ou rotação de culturas, devido à tolerância a diferentes tipos de climas e solos (Glovatski e Raiher, 2013; Gomes et al., 2015).

Apesar de o girassol ser considerado uma espécie com boa capacidade de aclimatação às diferentes condições de clima e solo, são escassos na literatura informações sobre os efeitos da suplementação com percolado de aterro sanitário no crescimento foliar e nas atividades das enzimas antioxidativas sob condições de estresse hídrico.

Diante do exposto, o presente trabalho objetivou analisar os efeitos da aplicação de percolado de aterro sanitário no crescimento foliar (número de folhas e área foliar) e nas atividades das enzimas antioxidativas em plântulas de girassol submetidas ao estresse hídrico.

\section{MATERIAL E MÉTODOS}

\subsection{Percolado de aterro sanitário utilizado no experimento}

O percolado utilizado no experimento foi coletado no mês de agosto de 2015, no Aterro Sanitário Metropolitano Oeste da Caucaia (ASMOC) na $3^{\text {a }}$ lagoa de estabilização (aeróbica facultativa) próxima ao vertedouro, localizado no município de Caucaia, Ceará, Brasil. A coleta do efluente obedeceu às normas de estocagem, manutenção e transporte, de acordo com os parâmetros físico-químicos analisados (Tabela 1).

Tabela 1. Caracterização físico-química do percolado de aterro sanitário utilizado no experimento.

\begin{tabular}{|c|c|c|c|c|c|c|c|c|c|c|c|}
\hline \multicolumn{12}{|c|}{$\mathrm{mg} \mathrm{L}^{-1}$} \\
\hline $\mathrm{N}-\mathrm{t}$ & $\mathrm{NH}_{4}$ & $\mathrm{NO}_{3-}$ & $\mathrm{NO}_{2-}$ & P-t & $\mathrm{Fe}^{+2}$ & $\mathrm{Zn}$ & $\mathrm{Mn}$ & $\mathrm{Cu}$ & $\mathrm{P}_{2} \mathrm{O}_{5}$ & $\mathrm{C} / \mathrm{N}$ & C.O.T. \\
\hline 504 & 323 & 153 & 19 & 7,9 & 16,1 & 22,3 & 24,5 & 1,5 & 18,1 & 1,39 & 660 \\
\hline \multicolumn{8}{|c|}{$\mathrm{mg} \mathrm{L}^{-1}$} & \multicolumn{4}{|c|}{$--\mathrm{dS} \mathrm{m}^{-1}$-- } \\
\hline $\mathrm{K}_{2} \mathrm{O}$ & $\mathrm{K}^{+}$ & $\mathrm{Na}^{+}$ & $\mathrm{Ca}^{2+}$ & $\mathrm{Mg}^{2+}$ & $\mathrm{Cl}^{-}$ & $\mathrm{CO}_{3}^{-2}$ & $\mathrm{HCO}_{3}^{-}$ & & $\mathrm{pH}$ & C.E. & RAS \\
\hline 2.196 & 1.800 & 234,6 & 54 & 58,5 & $2.428,5$ & 96 & 231,8 & & 7,8 & 7,6 & 5,37 \\
\hline
\end{tabular}

N-t: nitrogênio total; P-t: fósforo total; C/N: razão carbono nitrogênio; C.O.T.: carbono orgânico total; C.E.: condutividade elétrica; RAS: razão de adsorção de sódio. 


\subsection{Condições experimentais, tratamentos e coleta das plântulas}

O experimento foi conduzido em casa de vegetação localizada na cidade de Maracanaú, Ceará, Brasil, no período de Setembro a Outubro de 2015. Os valores médios de temperatura e umidade relativa do ar, foram, respectivamente, $32,1^{\circ} \mathrm{C}$ e $52 \%$.

As sementes de girassol (Helianthus annuus L.) do cultivar BRS 323 foram cedidas pela Embrapa Produtos e Mercados - Escritório Dourados, Mato Grosso do Sul, Brasil. Após seleção e desinfestação com solução de hipoclorito de sódio a $0,7 \%$, as sementes foram semeadas em vasos de plástico de $5 \mathrm{~L}$ preenchidos com: 1) areia de granulometria fina (NBR 6502); 2) areia + adubo/fertilizante orgânico comercial misto (11,8\% de nitrogênio - N) aplicado proporcionalmente ao correspondente a $100 \mathrm{~kg} \mathrm{~N} \mathrm{ha}^{-1} /$ vaso; 3) areia + percolado de aterro sanitário aplicado proporcionalmente ao correspondente a $100 \mathrm{~kg} \mathrm{~N} \mathrm{ha}^{-1} /$ vaso; 4) areia + percolado de aterro sanitário aplicado proporcionalmente ao correspondente a $150 \mathrm{~kg} \mathrm{~N} \mathrm{ha}^{-1} /$ vaso. Durante o experimento, foram realizadas regas diárias, mantendo-se a umidade próxima a $70 \%$ da capacidade de campo do substrato.

Decorridos 16 dias após a semeadura (DAS), metade de cada grupo de plantas de cada tratamento descrito acima, foi submetido à suspensão da rega. Foram realizadas 2 coletas: $1^{\mathrm{a}}$ ) aos 21 dias após a semeadura (5 dias sob estresse hídrico) e $2^{\mathrm{a}}$ ) aos 23 dias (7 dias sob estresse hídrico). Durante as coletas, determinaram-se: o número de folhas e a área foliar (usando-se o medidor de área foliar ADC, modelo: AM350).

$\mathrm{O}$ delineamento experimental foi inteiramente casualizado disposto em arranjo fatorial dois (irrigadas ou não irrigadas) x quatro (areia; areia + adubo orgânico $100 \mathrm{~kg} \mathrm{~N} \mathrm{ha}^{-1}$; areia + percolado de aterro $100 \mathrm{~kg} \mathrm{~N} \mathrm{ha}^{-1}$; areia + percolado de aterro $150 \mathrm{~kg} \mathrm{~N} \mathrm{ha}^{-1}$ ), com cinco repetições, cada uma constituída por um vaso com duas plantas. Os dados de cada período de coleta foram, independentemente, submetidos à análise de variância (ANOVA) e as médias foram comparadas pelo teste de Tukey $(P \leq 0,05)$ através do programa Sigma Plot 11.0.

\subsection{Preparação dos extratos enzimáticos e determinações das atividades das enzimas antioxidativas}

Para as determinações das atividades das enzimas antioxidativas foram preparados extratos de folhas e raízes frescas obtidas a partir da maceração, em almofariz, de $1 \mathrm{~g}$ de matéria fresca em nitrogênio líquido para obtenção do pó. Em seguida, adicionaram-se 4,0 $\mathrm{mL}$ de tampão fosfato de potássio a $100 \mathrm{mM}, \mathrm{pH} 7,0$, contendo EDTA a $0,1 \mathrm{mM}$. O macerado foi filtrado em tecido de náilon de malha fina e centrifugado a $12.000 \mathrm{x} \mathrm{g}$ durante 15 min.

Foram determinadas as atividades das enzimas CAT, GPX, APX e SOD. A atividade da CAT foi determinada de acordo com Havir e McHale (1987), pelo decréscimo na absorbância em $240 \mathrm{~nm}$, devido ao consumo de $\mathrm{H}_{2} \mathrm{O}_{2}$; a da GPX pelo método de Kar e Mishra (1976), sendo a reação acompanhada pelo incremento da absorbância em $470 \mathrm{~nm}$, devido à formação do tetraguaiacol; a da APX pelo método de Nakano e Asada (1981), sendo a oxidação do ascorbato medida pelo decréscimo na absorbância em $290 \mathrm{~nm}$, e a da SOD pelo método de Beauchamp e Fridovich (1971), sendo a reação medida através do aumento da absorbância em $560 \mathrm{~nm}$, devido à produção de formazana azul, resultante da fotorredução do p-Nitrobluetetrazolium (NBT). As atividades das enzimas CAT, APX e GPX foram expressas em $\mu$ mol $\mathrm{H}_{2} \mathrm{O}_{2} \mathrm{~min}^{-1} \mathrm{~g}^{-1} \mathrm{MF}$, e a da SOD em UA g ${ }^{-1} \mathrm{MF}$, onde MF representa matéria fresca e sendo uma UA (unidade de atividade enzimática) definida como sendo a quantidade de enzima necessária para causar $50 \%$ de inibição da fotorredução do NBT. Cada extrato foi dosado em duplicata. 


\section{RESULTADOS E DISCUSSÃO}

\subsection{Número de folhas e área foliar}

A análise de variância demonstrou que houve interações entre os fatores: diferentes suplementações de $\mathrm{N}$ com percolado no substrato, e irrigação (plantas irrigadas ou não irrigadas) utilizados no cultivo de maneira significativa a $1 \%$ de probabilidade $(P \leq 0,001)$ nas variáveis: número de folhas (NF) e área foliar (AF) (Tabela 2).

Tabela 2. Resumos das análises de variância do número de folhas (NF) e área foliar (AF) de plantas de girassol em diferentes suplementações de $\mathrm{N}$ com percolado nos substratos (areia; areia + adubo/fertilizante orgânico comercial misto a $100 \mathrm{~kg} \mathrm{~N} \mathrm{ha}^{-1}$; areia + percolado de aterro sanitário a $100 \mathrm{~kg} \mathrm{~N}^{-1}$; areia + percolado de aterro sanitário a $150 \mathrm{~kg} \mathrm{~N} \mathrm{ha}^{-1}$ ) sob condições controle e estresse hídrico aos 5 e 7 dias após a suspensão da irrigação.

\begin{tabular}{|c|c|c|c|c|c|}
\hline \multirow[b]{3}{*}{ Fonte de Variação } & \multirow[b]{3}{*}{ GL } & \multicolumn{4}{|c|}{ Quadrado Médio } \\
\hline & & \multicolumn{2}{|c|}{ NF } & \multicolumn{2}{|c|}{$\mathrm{AF}$} \\
\hline & & 05 dias & 07 dias & 05 dias & 07 dias \\
\hline Suplementação (S) & 3 & $13,36^{*}$ & $18,60^{*}$ & $5970,5^{*}$ & $7468,6^{*}$ \\
\hline Irrigação (I) & 1 & $19,60^{*}$ & $16,90^{*}$ & $572,2^{*}$ & $7942,5^{*}$ \\
\hline$S \times I$ & 3 & $1,40^{*}$ & $5,90^{*}$ & $124,7^{*}$ & $2138,6^{*}$ \\
\hline Erro & 32 & 0,16 & 0,06 & 5,83 & 10,12 \\
\hline Total Corrigido & 39 & - & - & - & - \\
\hline CV (\%) & - & 6,55 & 3,37 & 5,65 & 6,03 \\
\hline
\end{tabular}

$\mathbf{N F}=$ número de folhas;

$\mathbf{A F}=$ área foliar; $\mathrm{e}$

$* P \leq 0,001$.

De maneira geral, o estresse hídrico promoveu reduções no número de folhas e na área foliar em todos os tratamentos (Figuras 1A e 1B), com diferenças significativas em relação ao controle. Adicionalmente, na condição de estresse hídrico, verificou-se que o tratamento areia + percolado de aterro sanitário a $100 \mathrm{~kg} \mathrm{~N} \mathrm{ha}^{-1}$ apresentou os maiores valores de NF e $\mathrm{AF}$, com diferenças significativas em relação aos demais tratamentos, nos dois períodos de análise.

As reduções observadas no presente trabalho são semelhantes às encontradas por outros autores, tanto com plantas de girassol (Manivannan et al., 2007; Nobre et al., 2011; Dutra et al., 2012), como com outras espécies (Zhang et al., 2004; Wullschleger et al., 2005; Santos et al., 2012) sob condições de estresse hídrico ou salino.

O crescimento vegetal depende da divisão e expansão de suas células, sendo esta última condicionada à pressão de turgência, processo afetado pela baixa disponibilidade de água no solo ou pelo excesso de transpiração (Santos et al., 2014). De maneira adicional, Jaleel et al. (2009) afirmam que, sob condições de estresse hídrico, as plantas reduzem a emissão de novas folhas e a área foliar como mecanismo para evitar a perda de água por transpiração. Porém, isso pode ocasionar a diminuição da capacidade fotossintética do vegetal, bem como a formação de ROS (Silva et al., 2011).

Em relação aos efeitos das ROS sobre o NF e AF, Deuner et al. (2011) afirmam que em condições de estresses abióticos, é necessária a rápida eliminação das ROS pelas enzimas 
antioxidativas para se evitar a diminuição do crescimento e da produtividade do vegetal.

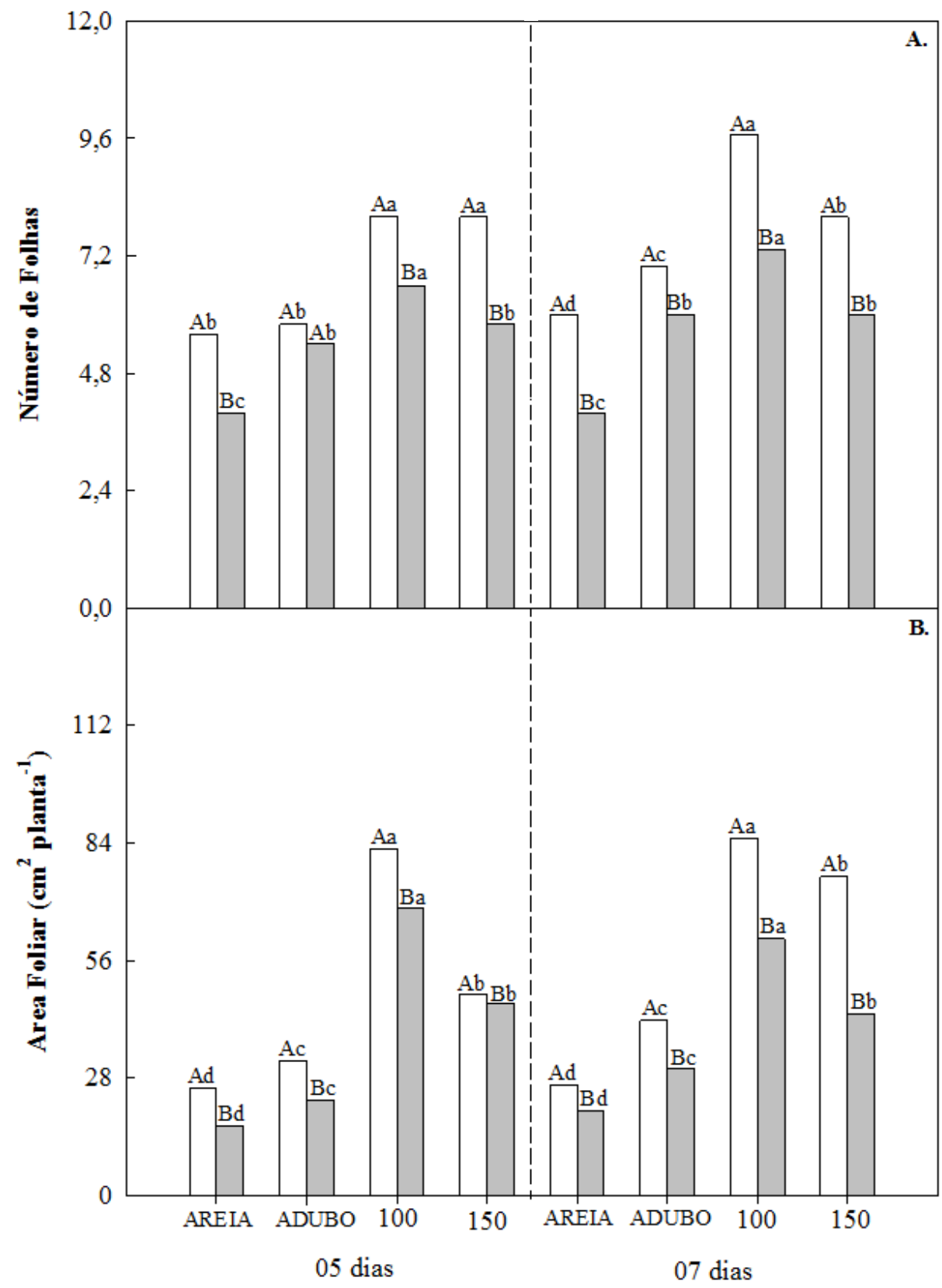

Figura 1. Número de folhas (A) e área foliar (B) de plantas de girassol aos 5 $\left(1^{\mathrm{a}}\right.$ coleta) e 7 dias ( $2^{\mathrm{a}}$ coleta) após a suspensão da irrigação (que ocorreu aos 16 dias após a semeadura) crescendo sob condições controle (barras brancas) ou de estresse hídrico (barras cinzas). Diferentes letras maiúsculas indicam diferenças significativas ao tipo de irrigação (controle e estresse), enquanto diferentes letras minúsculas indicam diferenças significativas em relação às diferentes suplementações de $\mathrm{N}$ com percolado nos substratos (areia; areia + adubo orgânico $100 \mathrm{~kg} \mathrm{~N} \mathrm{ha}^{-1}$; areia + percolado de aterro $100 \mathrm{~kg} \mathrm{~N}$ ha $^{-1}$; areia + percolado de aterro $\left.150 \mathrm{~kg} \mathrm{~N} \mathrm{ha}^{-1}\right)$, de acordo com o teste de Tukey $(P \leq$ $0,05)$. As análises estatísticas foram realizadas independentemente em cada coleta.

\subsection{Atividade enzimática nas folhas}

A análise de variância demonstrou que houve interações entre os fatores: diferentes 
suplementações de $\mathrm{N}$ com percolado no substrato, e irrigação (plantas irrigadas ou não irrigadas) utilizados no cultivo ( $\mathrm{T} \times \mathrm{I})$ de maneira significativa a $1 \%$ de probabilidade $(P \leq 0,001)$ nos parâmetros de atividade das enzimas CAT, APX, GPX e SOD em folhas de plantas de girassol aos 5 dias após suspensão da irrigação (Tabela 3). No entanto, aos 7 dias após suspensão da irrigação, a interação ( $\mathrm{T}$ x I) mostrou-se não significativa para a CAT e significativa a $5 \%$ de probabilidade $(P \leq 0,005)$ para a SOD.

Tabela 3. Resumos das análises de variância da atividade das enzimas, catalase (CAT), peroxidase do ascorbato (APX), peroxidase do guaiacol (GPX) e superóxido dismutase (SOD) em folhas de plantas de girassol em diferentes suplementações de $\mathrm{N}$ com percolado no substrato (areia; areia + adubo/fertilizante orgânico comercial misto a $100 \mathrm{~kg} \mathrm{~N} \mathrm{ha}^{-1}$; areia + percolado de aterro sanitário a $100 \mathrm{~kg} \mathrm{~N} \mathrm{ha}^{-1}$; areia + percolado de aterro sanitário a $150 \mathrm{~kg} \mathrm{~N} \mathrm{ha}^{-1}$ ) sob condições controle e estresse hídrico aos 5 e 7 dias após a suspensão da irrigação.

\begin{tabular}{|c|c|c|c|c|c|c|c|c|c|}
\hline \multirow[b]{3}{*}{ Fonte de Variação } & \multirow[b]{3}{*}{ GL } & \multicolumn{8}{|c|}{ Quadrado Médio } \\
\hline & & \multicolumn{2}{|c|}{ CAT } & \multicolumn{2}{|c|}{ APX } & \multicolumn{2}{|c|}{ GPX } & \multicolumn{2}{|c|}{ SOD } \\
\hline & & 05 dias & 07 dias & 05 dias & 07 dias & 05 dias & 07 dias & 05 dias & 07 dias \\
\hline Suplementação (S) & 3 & $1944,1^{*}$ & $3867,6^{*}$ & $0,048^{*}$ & $0,060^{*}$ & $0,24^{*}$ & $0,33^{*}$ & $181,8^{*}$ & $33,4^{*}$ \\
\hline Irrigação (I) & 1 & $185,3^{*}$ & $40,8^{\mathrm{ns}}$ & $0,155^{*}$ & $0,087^{*}$ & $1,12^{*}$ & $1,01^{*}$ & $10,9^{*}$ & $45,3^{*}$ \\
\hline $\mathrm{S} \times \mathrm{I}$ & 3 & $51,4^{*}$ & $2,45^{\mathrm{ns}}$ & $0,039^{*}$ & $0,004^{\text {ns }}$ & $0,13^{*}$ & $0,05^{*}$ & $3,8^{*}$ & $4,2^{* *}$ \\
\hline Erro & 32 & 6,1 & $9,53^{*}$ & 0,0019 & 0,0009 & 0,014 & 0,004 & $0,27^{*}$ & 0,80 \\
\hline Total Corrigido & 39 & - & - & - & - & - & - & - & - \\
\hline CV (\%) & - & 12,1 & 13,3 & 15,07 & 10,4 & 5,44 & 3,23 & 0,69 & 1,21 \\
\hline
\end{tabular}

Na Figura 2 são apresentadas as atividade das enzimas SOD, CAT, APX e GPX em folhas de plântulas de girassol aos 5 e 7 dias após suspensão da irrigação.

As atividades da SOD nas folhas (Figura 2A) mostraram-se maiores aos 5 e 7 dias nas plântulas suplementadas com percolado de aterro sanitário (100 e $150 \mathrm{~kg} \mathrm{~N}^{-1}$ ) e que tiveram a irrigação suspensa. De maneira adicional, as plântulas suplementadas com percolado de aterro sanitário não diferiram entre si na condição de suspensão da irrigação, e mostraram, em média, atividades superiores aos dos tratamentos areia e adubo em $4 \%$ e $7 \%$, respectivamente.

As atividades da CAT nas folhas das plântulas de girassol (Figura 2B) foram mais elevadas nos tratamentos suplementados com percolado de aterro nos dois períodos de coleta (aos 5 e 7 dias após suspensão da irrigação). De maneira adicional, em uma mesma suplementação de $\mathrm{N}$, no segundo período de coleta, não foram verificadas diferenças significativas nas atividades enzimáticas das plantas controle (irrigadas) e estresse (não irrigadas) em nenhum dos tratamentos. 


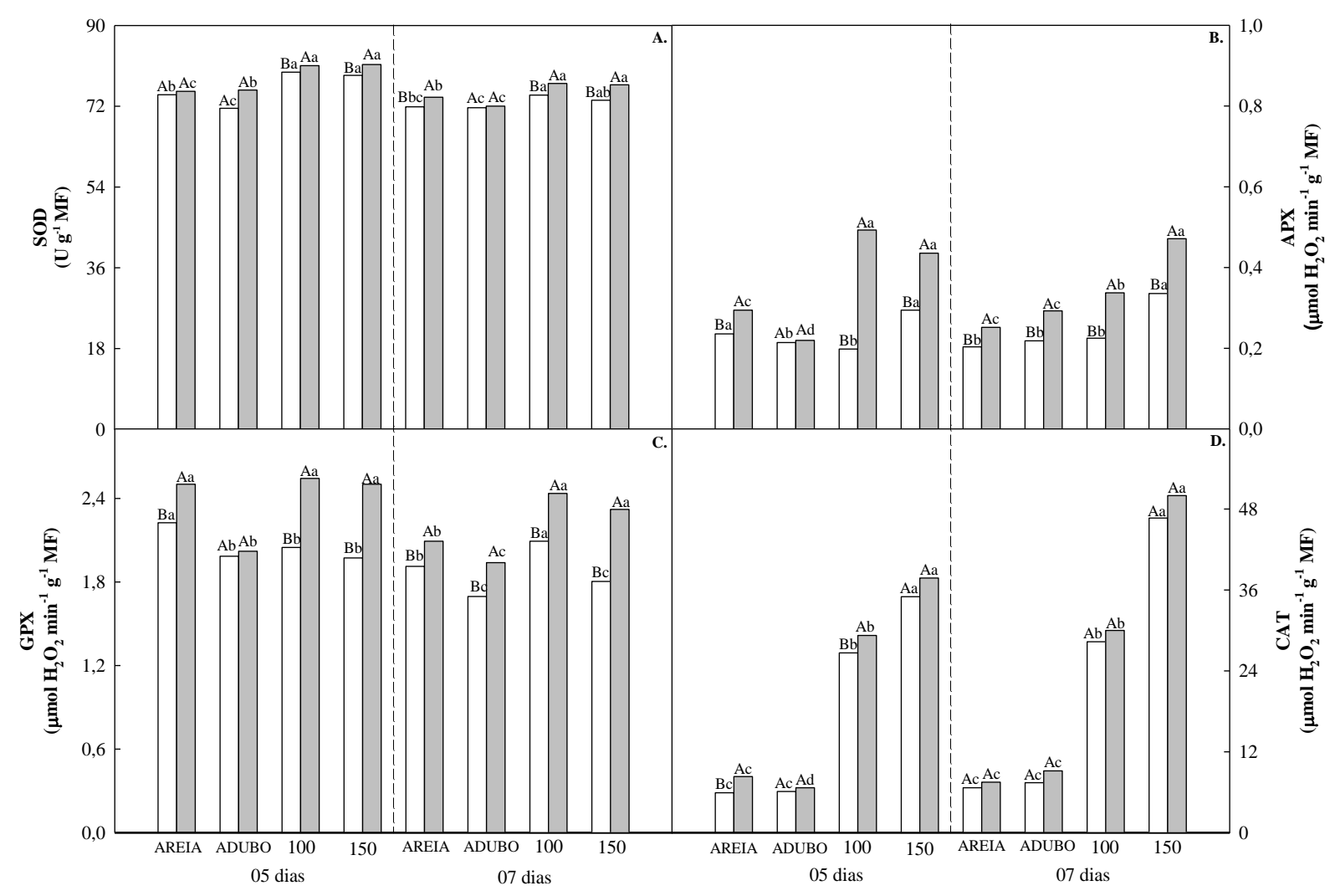

Figura 2. Atividade das enzimas superóxido dismutase - SOD (A), peroxidase do ascorbato APX (B), peroxidase do guaiacol - GPX (C) e catalase - CAT (D) em folhas de plantas de girassol aos 05 ( $1^{\mathrm{a}}$ coleta) e 07 dias ( $2^{\mathrm{a}}$ coleta) após a suspensão da irrigação (que ocorreu aos 16 dias após a semeadura) crescendo sob condições controle (barras brancas) ou de estresse hídrico (barras cinzas). Detalhes adicionais na legenda da Figura 1.

Aos 5 e 7 dias de suspensão da irrigação, sob condições de estresse, a atividade da APX nas folhas (Figura 2C), mostrou-se mais elevada nos tratamentos 100 e $150 \mathrm{~kg} \mathrm{~N} \mathrm{ha}^{-1}$. Adicionalmente, no segundo período de coleta, o tratamento suplementado com percolado a $150 \mathrm{~kg} \mathrm{~N} \mathrm{ha}^{-1}$ apresentou diferenças em relação aos tratamentos areia e adubo de 87 e $61 \%$, respectivamente.

Já para a atividade da GPX nas folhas das plantas de girassol (Figuras 2D), após 5 dias de suspensão da irrigação, sob condições de estresse, as maiores atividades enzimáticas foram observadas nos tratamentos areia e percolado de aterro sanitário (100 e $150 \mathrm{~kg} \mathrm{~N}^{-1}$ ), não havendo diferenças estatísticas entre si. Entretanto, aos 7 dias de suspensão da irrigação, os tratamento com percolado apresentaram atividades superiores aos tratamentos areia e adubo, de 16 e $26 \%$ respectivamente.

\subsection{Atividade enzimática nas raízes}

A análise de variância demonstrou que houve interações entre os fatores: diferentes suplementações de $\mathrm{N}$ com percolado no substrato, e irrigação (plantas irrigadas ou não irrigadas), utilizados no cultivo ( $\mathrm{T}$ x I) de maneira significativa a $1 \%$ de probabilidade $(P \leq 0,001)$ nas atividades de APX, GPX e SOD em raízes de plantas de girassol aos 7 dias após suspensão da irrigação (Tabela 4). No entanto, aos 5 dias após a suspensão da irrigação, a interação ( T x I) mostrou-se não significativa para a enzima APX. 
Tabela 4. Resumos das análises de variância da atividade das enzimas, peroxidase do ascorbato (APX), peroxidase do guaiacol (GPX) e superóxido dismutase (SOD) em raízes de plantas de girassol em diferentes suplementações de $\mathrm{N}$ com percolado no substrato (areia; areia + adubo/fertilizante orgânico comercial misto a $100 \mathrm{~kg} \mathrm{~N}^{-1}$; areia + percolado de aterro sanitário a $100 \mathrm{~kg} \mathrm{~N} \mathrm{ha}^{-1}$; areia + percolado de aterro sanitário a $150 \mathrm{~kg} \mathrm{~N} \mathrm{ha}^{-1}$ ) sob condições controle e estresse hídrico aos 5 e 7 dias após a suspensão da irrigação.

\begin{tabular}{|c|c|c|c|c|c|c|c|}
\hline \multirow[b]{3}{*}{ Fonte de Variação } & \multirow[b]{3}{*}{ GL } & \multicolumn{6}{|c|}{ Quadrado Médio } \\
\hline & & \multicolumn{2}{|c|}{ APX } & \multicolumn{2}{|c|}{ GPX } & \multicolumn{2}{|c|}{ SOD } \\
\hline & & 05 dias & 07 dias & 05 dias & 07 dias & 05 dias & 07 dias \\
\hline Suplementação (S) & 3 & $0,020^{*}$ & $0,064^{*}$ & $2,97^{*}$ & $1,33^{*}$ & $71,1^{*}$ & $23,74^{*}$ \\
\hline Irrigação (I) & 1 & $0,00009^{\mathrm{ns}}$ & $0,193^{*}$ & $2,03^{*}$ & $14,06^{*}$ & $367,2^{*}$ & $47,74^{*}$ \\
\hline S x I & 3 & $0,002^{\mathrm{ns}}$ & $0,040^{*}$ & $0,36^{*}$ & $3,20^{*}$ & $83,1^{*}$ & $26,18^{*}$ \\
\hline Erro & 32 & 0,0011 & 0,0011 & 0,011 & 0,008 & 3,60 & 2,06 \\
\hline Total Corrigido & 39 & - & - & - & - & - & - \\
\hline $\mathrm{CV}(\%)$ & - & 11,2 & 12,1 & 6,5 & 5,7 & 3,09 & 2,3 \\
\hline
\end{tabular}

Na Figura 3, são apresentadas as atividade das enzimas SOD, APX e GPX em raízes de plantas de girassol aos 5 e 7 dias após a suspensão da irrigação. $\mathrm{Na}$ atividade da SOD nas raízes (Figura 3A), aos 5 e 7 dias após suspensão da irrigação, foram verificadas diferenças entre o controle e o estresse apenas nos tratamentos que receberam percolado. Adicionalmente, aos 7 dias, na condição de estresse, verificou-se uma maior atividade enzimática no tratamento suplementado com percolado a $100 \mathrm{~kg} \mathrm{~N} \mathrm{ha}^{-1}$, com diferenças de $5 \mathrm{e}$ $11 \%$ em relação aos tratamentos areia e adubo, respectivamente.

No presente trabalho, não foram verificadas atividades da enzima CAT nas raízes das plântulas de girassol.

Aos 5 dias após suspensão da irrigação, nas raízes das plântulas de girassol, não houve diferenças significativas entre os tratamentos controle e estresse na atividade da APX (Figura 3B). No entanto, aos 7 dias após suspensão da irrigação, a atividade da APX mostrou-se mais elevada nas plantas submetidas a estresse quando comparadas com seus respectivos controles. De maneira adicional, sob condições de estresse, o tratamento $100 \mathrm{~kg} \mathrm{~N}$ (areia + percolado de aterro sanitário) apresentou a maior atividade da APX, com diferenças de 64 e $158 \%$ em relação aos tratamentos areia e adubo, respectivamente.

Para a atividade da GPX nas raízes (Figura 3C), de modo geral os tratamentos submetidos a estresse hídrico e suplementados com percolado apresentaram maiores atividades enzimáticas. Entretanto, nos dois períodos de análise, o tratamento $150 \mathrm{~kg} \mathrm{~N} \mathrm{ha}{ }^{-1}$ apresentou os maiores valores de atividade da GPX, sendo as diferenças para os tratamentos areia de 138 e $112 \%$, e adubo de 94 e $120 \%$, aos 5 e 7 dias após a suspensão da irrigação, respectivamente. 


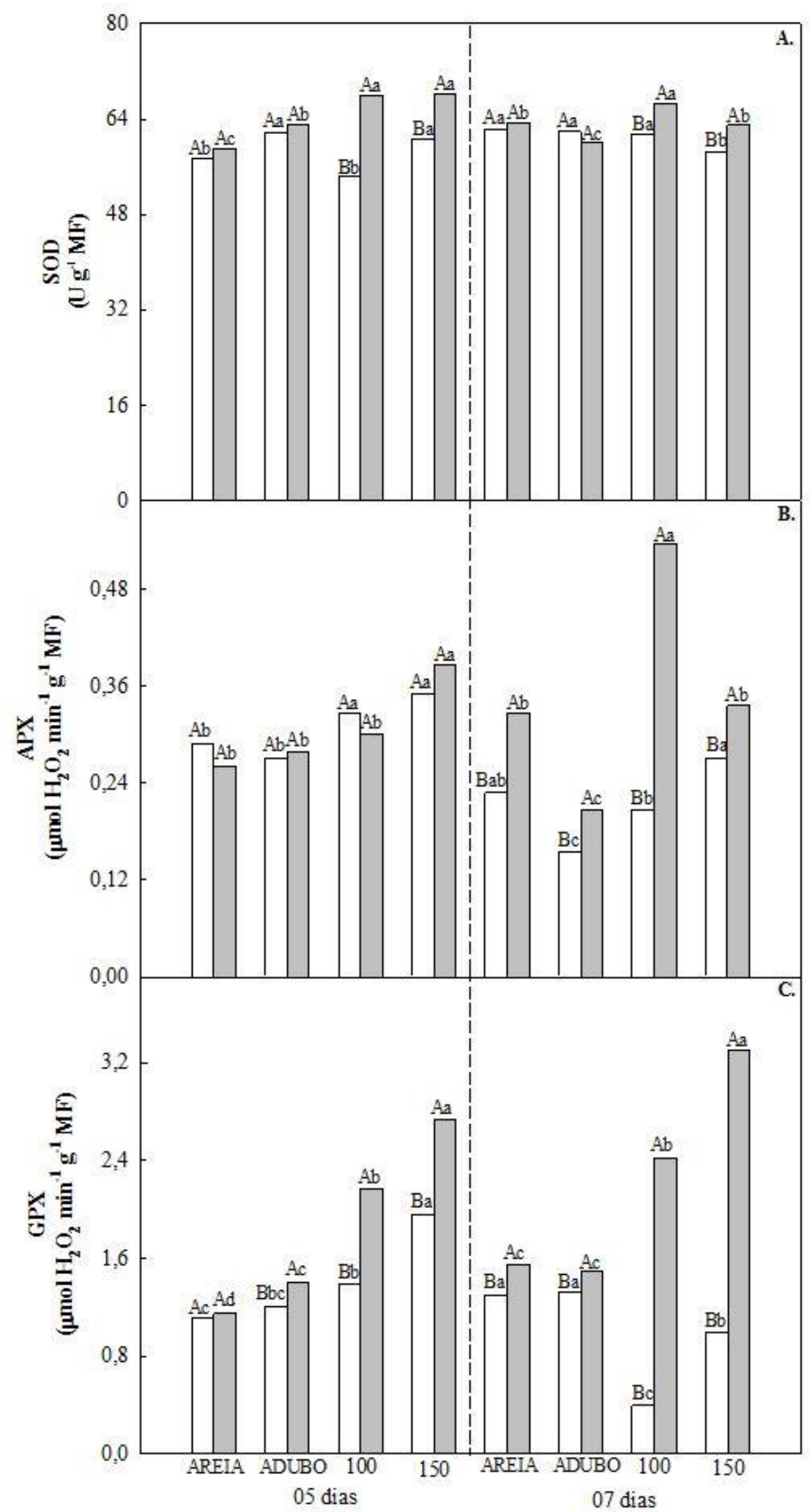

Figura 3. Atividade das enzimas superóxido dismutase - SOD (A), peroxidase do ascorbato - APX (B), peroxidase do guaiacol - GPX (C) e catalase - CAT (D) em folhas de plantas de girassol aos 05 ( $1^{\text {a }}$ coleta) e 07 dias ( $2^{\mathrm{a}}$ coleta) depois de submetidas a estresse hídrico crescendo sob condições controle (barras brancas) ou estresse hídrico (barras cinzas). Detalhes adicionais na legenda da Figura 1. 
De modo geral, na condição de estresse hídrico, a aplicação de percolado de aterro sanitário promoveu aumentos nas atividades enzimáticas de folhas e raízes em relação aos demais tratamentos. Resultados similares são descritos em estudos com girassol (Manivannan et al., 2007; Carneiro et al., 2011) e outras espécies (Azevedo Neto et al., 2010; Carneiro et al.; 2015) sob condições de estresse hídrico e salino.

De maneira adicional, há um consenso entre diversos autores sobre os aumentos nas atividades das enzimas antioxidativas em plantas e seus benefícios no controle ao aumento das ROS e promoção da aclimatação das plantas aos estresses abióticos (Willadino et al., 2011; Gondim et al., 2012; Kanungo e Joshi, 2014; Jadoski et al.; 2015).

Verificou-se que nas folhas das plântulas de girassol suplementadas com percolado, a maior atividade da SOD nas condições de estresse promoveu maiores atividades da CAT e das peroxidases (APX e GPX) em relação aos demais tratamentos. Isto pode ser explicado pelo fato de a SOD ser a primeira enzima envolvida no sistema de defesa das plantas, atuando na dismutação do radical superóxido $\left(\mathrm{O}_{2}{ }^{-}\right)$em peróxido de hidrogênio $\left(\mathrm{H}_{2} \mathrm{O}_{2}\right)$, substrato de catálise das peroxidases (Gill e Tuteja, 2010).

No entanto, dentre as enzimas avaliadas nas folhas, a suplementação com percolado de aterro sanitário promoveu aumentos substanciais na atividade da CAT em relação à APX e à GPX. Aos 7 dias após suspensão da irrigação, na condição de estresse hídrico, verificou-se atividades na ordem de $50 \mu \mathrm{mol} \mathrm{H}_{2} \mathrm{O}_{2} \mathrm{~min}^{-1} \mathrm{~g}^{-1} \mathrm{MF}$ para a CAT, o que comprova ter havido uma maior eliminação de peróxido de hidrogênio nas plântulas dos respectivos tratamentos.

As inferências acima podem ser feitas em virtude da enzima CAT ser a principal enzima a catalisar a eliminação do $\mathrm{H}_{2} \mathrm{O}_{2}$ (Scandalios, 2005; Jaleel et al., 2009). Além disso, semelhantemente, ao presente trabalho, Akcay et al. (2010), analisando a atividade da CAT em Arachis hypogaea L., também verificaram aumentos acentuados da enzima em condições de estresse hídrico. Adicionalmente, os autores afirmaram que a CAT é uma das enzimas mais eficazes na defesa contra processos oxidativos. Assim, elevadas atividades em Arachis hypogaea L. sob condições de estresse representariam uma melhor capacidade de aclimatação da espécie.

De maneira adicional, Carneiro et al. (2015), avaliando os efeitos de diferentes fontes de nitrogênio no metabolismo antioxidativo em plantas de seringueira, verificaram que os tratamentos que receberam maiores concentrações de $\mathrm{N}$ apresentaram maiores atividades de CAT. Dessa forma, é provável que os aumentos na atividade da CAT no presente trabalho também esteja relacionado ao fornecimento de $\mathrm{N}$ através do percolado.

Em relação às raízes, apesar de não terem sido observadas atividades da CAT, verificouse maiores atividades da SOD e das peroxidases (APX e GPX) nas plântulas suplementadas com percolado de aterro e submetidas a estresse hídrico. Sendo mais elevada a atividade da GPX no tratamento $150 \mathrm{~kg} \mathrm{~N} \mathrm{ha}^{-1}$, nos dois períodos de coleta.

A APX e a GPX são enzimas que necessitam de agentes redutores para a eliminação do $\mathrm{H}_{2} \mathrm{O}_{2}$, sendo, portanto, responsáveis pela regulação fina da concentração de $\mathrm{H}_{2} \mathrm{O}_{2}$ em função da alta afinidade com esta ROS (Ahmad et al., 2010; Silveira et al., 2010; Pereira et al., 2012).

De maneira similar aos resultados verificadas no presente trabalho, Chai et al. (2010), constataram aumentos na atividade da GPX em raízes de plantas de sorgo submetidas a estresse salino. Adicionalmente, Aumonde et al. (2013) identificaram, em raízes de plantas de arroz submetidas a diferentes intensidades de luz, as enzimas APX e GPX como sendo as principais responsáveis pela eliminação do $\mathrm{H}_{2} \mathrm{O}_{2}$.

Perante o exposto, são positivos os aumentos de atividades antioxidativas observados nas raízes e folhas das plântulas suplementadas com percolado, em particular as da CAT nas folhas. Deste modo, é provável que os aumentos nas atividades das enzimas antioxidativas teriam contribuído para minimizar os efeitos deletérios do estresse hídrico nas variáveis de crescimento analisadas (número de folhas e área foliar). 


\section{CONCLUSÕES}

- A aplicação de percolado de aterro sanitário a 100 e $150 \mathrm{~kg} \mathrm{~N}^{-1}$ promoveu os incrementos nas variáveis número de folhas e área foliar, em comparação aos tratamentos areia e adubo, tanto para as condições de controle (plantas irrigadas) como de estresse hídrico (plantas não irrigadas).

- O estresse hídrico promoveu redução no número de folhas e área foliar. No entanto, no tratamento $100 \mathrm{~kg} \mathrm{~N} \mathrm{ha}^{-1}$ suplementado com percolado de aterro sanitário, os efeitos deletérios do estresse hídrico foram minimizados.

- A suplementação com percolado de aterro promoveu aumentos significativos nas atividades das enzimas antioxidativas em folhas e raízes de plântulas de girassol.

\section{REFERÊNCIAS}

AKCAY, U. C.; ERCAN, O.; KAVAS, M.; YILDIZ, L.; YLMAZ, C.; OKTEM, H. A.; YUCEL, M. Drought-induced oxidative damage aond antioxidant responses in peanut (Arachis hygaeae L.) seedling. Plant Growth Regulation, v. 61, p. 21-28, 2010. http://dx.doi.org/10.1007/s10725-010-9445-1

AHMAD, P.; JALEEL, C. A.; SALEM, M. A.; NABI, G.; SHARMA, S. Roles of enzymatic and nonenzymatic antioxidants in plants during abiotic stress. Critical Reviews in Biotechnology, Boca Raton, v. 30, p. 161-175, 2010. http://dx.doi.org/ 10.3109/07388550903524243

AUMONDE, T. Z.; PEDÓ, T.; JUNIOR BORELLA; AMARANTE, L.; VILLELA, F. A. Seed vigor, antioxidant metabolism and initial growth characteristics of red rice seedlings under different light intensities. Acta Botanica Brasilica, v. 27, p. 311-317, 2013. http://dx.doi.org/10.1590/S0102-33062013000200007

AZEVEDO NETO, A. D.; NOGUEIRA, R. J. M. C.; MELO FILHO, P. A.; SANTOS, R. C. Physiological and biochemical responses of peanut genotypes to water déficit. Journal of Plant Interactions, v. 5, p. 1-10, 2010. http://dx.doi.org/10.1080/ 17429140902999243

BARBOSA, M. R.; SILVA, M. M. de A.; ULISSES, L. W. C.; CAMARA, T. R. Geração e desintoxicação enzimática de espécies reativas de oxigênio em plantas. Ciência Rural, v. 44, p. 453-460, 2014. http://dx.doi.org/10.1590/S0103-84782014000300011

BEAUCHAMP, C.; FRIDOVICH, I. Superoxide dismutase: improved assays and an assay applicable to acrylamide gels. Analytical Biochemistry, v. 44, p. 276-287, 1971. http://dx.doi.org/10.1016/0003-2697(71)90370-8

CARNEIRO, M. M. L. C.; DEUNER, S.; OLIVEIRA, P. D. de; TEIXEIRA, S. B.; SOUSA, C. P.; BACARIN, M. A. et al. Atividade antioxidante e viabilidade de sementes de girassol após estresse hídrico e salino. Revista Brasileira de Sementes, v. 33, p. 752$761,2011$.

CARNEIRO, M. M. L. C.; GOMES, M. P.; SANTOS, H. R. B.; REIS, M. V. dos; MENDONÇA, A. M. das C.; OLIVEIRA, L. E. M. de. Fotorrespiração e metabolismo antioxidante em plantas jovens de seringueira cultivadas sob diferentes fontes de nitrogênio $\left(\mathrm{NO}_{3}{ }^{-}\right.$e $\left.\mathrm{NH}_{4}{ }^{+}\right)$. Revista Brasileira de Ciências Agrárias, v. 10, p. 66-73, 2015. http://dx.doi.org/10.5039/agraria.v10i1a4941 
CANTO, T. do; PICH, C. T.; GEREMIAS, R. Bioensaio de toxicidade em percolados no aterro sanitário do município de Araranguá (Santa Catarina, Brasil). Revista Biociências, v. 19, p. 53-60, 2013.

CERQUEIRA, R. C.; COSTA, J. M.; CHAVES, M. M.; RODRIGUES, J. D. Fisiologia e metabolismo foliar em duas variedades de videira sujeitas a um ciclo de défice hídrico e reidratação. Revista Brasileira de Ciências Agrárias, v. 10, p. 211-217, 2015.

CHAI, Y. Y.; JIANG, C. D.; SHI, L.; SHI, T. S.; GU, W. B. Effects of exogenous spermine on sweet sorghum during germination under salinity. . Biologia Plantarum, v. 54, p. 145-148, 2010. http://dx.doi.org/10.1007/s10535-010-0023-1

COELHO, D. C. L.; BATISTA, R. O.; SILVA, P. C. M. da. MESQUITA, F. O. Produção de capim elefante utilizando percolado de aterro sanitário. Bioscience Journal, v. 31, p. 830-840, 2015. http://dx.doi.org/10.14393/BJ-v31n3a2015-22400

DEUNER, C.; MAIA, M. de S.; DEUNER, S.; ALMEIDA, A. da S.; MENEGHELLO, G. E. Variabilidade e atividade antioxidante de sementes de genótipos de feijão miúdo submetidos ao estresse salino. Revista Brasileira de Sementes, v. 33, p. 713-722, 2011.

DEUNER, S.; ALVES, J. D.; FRIES, D. D.; ZANANDREA, I.; LIMA, A. A.; HENRIQUE, P. de C. et al. Peróxido de hidrogênio e ácido ascórbico influenciando a atividade de enzimas antioxidantes de mudas de cafeeiro. Revista Ceres, v. 55, p. 135-140, 2008.

DUTRA, C. C.; PRADO, E. A. F.; PAIM, L. R.; SCALON, S. de P. Q. Desenvolvimento de plantas de girassol sob diferentes condições de fornecimento de água. Semina: Ciências Agrarias, v. 33, p. 2657-2668, 2012.

FOOD AND AGRICULTURE ORGANIZATION - FAO. World Food and Agricultura. Rome, 2013. 134 p.

GILL, S. S.; TUTEJA, N. Reactive oxygen species and antioxidant machinery in abiotic stress tolerance in crop plants. Plant Physiology and Biochemistry, v. 48, p. 909-930, 2010. http://dx.doi.org/10.1016/j.plaphy.2010.08.016

GONDIM, F. A.; MIRANDA, R. S.; GOMES-FILHO, E.; PRISCO, J. T. Enhanced salt tolerance in maize plants induced by $\mathrm{H}_{2} \mathrm{O}_{2}$ leaf spraying is associated with improved gas Exchange rather than with non-enzymatic antioxidant system. Theoretical and Experimental Plant Physilogy, v. 25, p. 251-260, 2012. http://dx.doi.org/10. 1590/S2197-00252013000400003

GHOBADI, M.; TAHERABADI, S.; GHOBADI, M.; MOHAMMADI, G.; JALALIHONARMAND, S. Antioxidant capacity, photosynthetic characteristics and water relations of sunflower (Helianthus annuus L.) cultivars in response to drought stress.

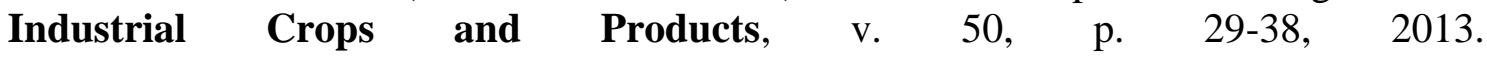
http://dx.doi.org/10.1016/j.indcrop.2013.07.009

GLOVATSKI; T. G. G.; RAIHER, A. P. A oferta de matérias primas (oleaginosas) do biodiesel no Brasil e seus determinantes: uma análise dos anos de 1991 a 2010. Estudo \& Debate, v. 20, p. 07-32, 2013. 
GOMES, K. R.; SOUSA, G. G. de; LIMA, F. A.; VIANA, T. V. de A.; AZEVEDO, B. M. de; SILVA, G. L. da. Irrigação com água salina na cultura do girassol (Helianthus annuus L.) em solo com biofertilizante bovino. Irriga, v. 20, p. 680-693, 2015. http://dx.doi.org/10.15809/irriga.2015v20n4p680

HAVIR, E.; McHALE, N. A. Biochemical and developmental characterization of multiple forms of catalases in tobacco leaves. Plant Physiology, v. 84, p.450-455, 1987. http://dx.doi.org/10.1104/pp.84.2.450

JADOSKI, C. J.; RODRIGUES, J. D.; SORATTO, R. P.; SANTOS, C. M. dos; RIBEIRO, E. Ação fisiológica da piraclostrobina na assimilação de $\mathrm{CO}_{2}$ e na atividade de enzimas antioxidantes em plantas de feijão em diferentes tensões de água no solo. Irriga, v. 20, p. 319-333, 2015. http://dx.doi.org/10.15809/irriga.2015v20n2p319

JALEEL, C. A.; MANIVANNAN, P.; WAHID, A.; FAROOQ, M.; AL-JUBURI, H. J.; SOMASUNDARAM, R. et al. Drought stress in plants: a review on morphological characteristics and pigments composition. International Journal of Agriculture \& Biology, v. 11, p. 1-6, 2009.

KANUNGO, M.; JOSHI, J. Impact of Pyraclostrobin (F-500) on crop plants. Plant Science Today, Trivandrum, v. 3, p. 174-178, 2014.

KAR, M.; MISHRA, D. Catalase, peroxidase, and polyphenoloxidase activities during rice leaf senescence. Plant Physiology, v.57, p.315-319, 1976.

http://dx.doi.org/10.1104/pp.57.2.315

KARUPPANAPANDIAN, T.; MOON, J.; KIM, C.; MANOHARAN, K.; KIM, W. Reactive oxygen species in plants: their generation, signal transduction, and scavenging mechanisms. Australian Journal of Crop Science, v. 5, p. 709-725, 2011.

MANIVANNAN, P.; JALEEL, C.A.; SANKAR, B.; KISHOREKUMAR, A.; SOMASUNDARAM, R.; LAKSHMANAN, G. M. A. et al. Growth, biochemical modifications and proline metabolism in Helianthus annuus L. as induced by drought stress. Colloids and Surfaces B: Biointerfaces, v. 59, p. 141-149, 2007. http://dx.doi.org/10.1016/j.colsurfb.2007.05.002

MILLER, G.; SUZUKI, N.; ÇIFTÇI-YILMAZ, S.; MITTLER, R. Reactive oxygen species homeostasis and signalling during drought and salinity stresses. Plant, Cell \& Environment, v. 33, p. 453-467, 2010. 10.1111/j.1365-3040.2009.02041.x

NAKANO, Y.; ASADA, K. Hydrogen peroxide is scavenged by ascorbate-specific peroxidase in spinash chloroplasts. Plant \& Cell Physiology, v. 22, p. 867-880, 1981.

NATIONAL SUNFLOWER ASSOCIATION. Sunflower sustainability: the substance behind the seed. 2010. Disponível em: https://goo.gl/lBTv19. Acesso em: 12 de mar. de 2016.

NOBRE, R. G.; GHEYI, H. R.; SOARES, F. A. L.; CARDOSO, J. A. F. Produção de girassol sob estresse salino e adubação nitrogenada. Revista Brasileira de Ciência do Solo, v. 35, p. 929-937, 2011. http://dx.doi.org/10.1590/S0100-06832011000300027 
PEREIRA, J. W. de L.; MELO FILHO, P. de A.; ALBUQUERQUE, M. B.; NOGUEIRA, R. J. M. C.; SANTOS, R. C. Mudanças bioquímicas em genótipos de amendoim submetidos a déficit hídrico moderado. Revista Ciência Agronômica, v. 43, p. 766$773,2012$.

REN, J.; SUN, L. N.; ZHANG, Q. Y.; SONG, X. S. Drought tolerance is correlated with the activity of antioxidante enzymes in Cerasus humilis seedlings. BioMed Research International, v. 2016, p. 1-9, 2016. http://dx.doi.org/10.1155/2016/9851095

SANTOS, D. dos; GUIMARÃES, V. F.; KLEIN, J.; FIOREZE, S. L.; MACEDO JÚNIOR, E. K. Cultivares de trigo submetidas a déficit hídrico no início do florescimento, em casa de vegetação. Revista Brasileira de Engenharia Agrícola e Ambiental, v.16, p. 836842, 2012. http://hdl.handle.net/11449/40463

SANTOS, J. C. C. dos; SILVA, C. H. da; SANTOS, C. S. dos; SILVA, C. de S.; MELO, E. B.; BARROS, A. C. Análise de crescimento e evapotranspiração da cultura do rabanete submetido a diferentes lâminas de água. Revista Verde de Agroecologia e Desenvolvimento Sustentável, v.9, p. 151-156, 2014.

SILVA, M. B. R.; FERNANDES, P. D.; NETO, J. D.; NERY, A. R.; RODRIGUES, L. N.; VIÉGAS, R. A. Crescimento e produção do pinhão-manso irrigado com água residuária sob condições de estresse hídrico. Revista Brasileira de Engenharia Agrícola e Ambiental, v. 15, p. 621-629, 2011. http://dx.doi.org/10.1590/S1415-43662011 000600013

SILVEIRA, J. A. G.; SILVA, S. L. F.; SILVA, E. N.; VIÉGAS, R. A. Mecanismos biomoleculares envolvidos com a resistência ao estresse salino em plantas. In: GHEYI, H. R.; DIAS, N. S.; LACERDA, C. F. (eds.). Manejo da salinidade na agricultura: estudos básicos e aplicados. 1. ed. Fortaleza: INCTSal. 2010. cap. 11. p. 161-185.

SCANDALIOS, J. G. Oxidative stress: Molecular perception and transduction of signals triggering antioxidant gene defenses. Brazilian Journal of Medical and Biological Research, v. 38, p.995-1014, 2005. http://dx.doi.org/10.1590/S0100-879X200 5000700003

SHARMA, P.; JHA, A. B.; DUBEY, R. S.; PESSARAKLI, M. Reactive oxygen species, oxidative damage, and antioxidative defense mechanism in plants under stressful conditions. Journal of Botany, v. 2012, p. 1-26, 2012.

http://dx.doi.org/10.1155/2012/217037

SHEHAB, G. G.; AHMED, O. K.; EL-BELTAGI, H. S. Effects of Various Chemical Agents for Alleviation of Drought stress in rice plants (Oryza sativa L.). Notulae Botanicae Horti Agrobotanici Cluj-Napoca, v. 38, p. 139-148, 2010.

WILLADINO, L.; OLIVEIRA FILHO, R. A.; SILVA JUNIOR, E. A.; GOUVEIA NETO, A.; CAMARA, T. R. Estresse salino em duas variedades de cana-de-açúcar: enzimas do sistema antioxidativo e fluorescência da clorofila. Revista Ciência Agronômica, v. 42, p. 417-422, 2011.

WULLSCHLEGER, S. D.; YIN, T. M.; DIFAZIO, S. P.; TSCHAPLINSKI, T. J.; GUNTER, L. E.; DAVIS, M. F. et al. Phenotypic variation in growth and biomass distribution for two advanced-generation pedigrees of hybrid poplar. Canadian Journal of Forest Research, v. 35, p. 1779-1789, 2005. http://dx.doi.org/10.1139/x05-101 
XAVIER, D. A.; FURTADO, G. de F.; SOUSA JÚNIOR, J. R. de; SOUSA, J. R. M. de; ANDRADE, E. M. G. Produção de fitomassa do milho sob lâminas de irrigação e adubação nitrogenada. Revista Verde de Agroecologia e Desenvolvimento Sustentável, v. 9, p. 144-148, 2014.

ZHANG, M.; DUAN, L.; ZHAI, Z.; LI, J.; TIAN, X.; WANG, B.; HE, Z.; LI, Z. Effects of plant growth regulators on water deficit-induced yield loss in soybean. In: INTERNATIONAL CROP SCIENCE CONGRESS, 4., 2004, Brisbane. Proceedings... Madison: Crop Science, 2004. Disponível em: https://goo.gl/gdIXmb. Acesso: 08 mar. 2016. 


Ambiente \& Água - An Interdisciplinary Journal of Applied Science
ISSN 1980-993X - doi:10.4136/1980-993X
www.ambi-agua.net
E-mail: ambi.agua@gmail.com

\title{
Análise de metodologias de quantificação de substâncias húmicas em lixiviados de aterros de resíduos sólidos
}

\author{
doi:10.4136/ambi-agua.1972
}

Received: 17 Jul. 2016; Accepted: 24 Nov. 2016

\author{
Letícia Sobral Maia S. Lima ${ }^{1}$; Ronei de Almeida ${ }^{1}$; \\ Bianca Ramalho Quintaes ${ }^{2}$; Daniele Maia Bila ${ }^{3}$; \\ Juacyara Carbonelli Campos ${ }^{1^{*}}$ \\ ${ }^{1}$ Universidade Federal do Rio de Janeiro (UFRJ), Rio de Janeiro, RJ, Brasil \\ Departamento de Processos Inorgânicos \\ ${ }^{2}$ Companhia Municipal de Limpeza Urbana (COMLURB), Rio de Janeiro, RJ, Brasil \\ Gerência de Pesquisas Aplicadas \\ ${ }^{3}$ Universidade do Estado do Rio de Janeiro (UERJ), Rio de Janeiro, RJ, Brasil \\ Departamento de Engenharia Sanitária e do Meio Ambiente (DESMA) \\ *Autor correspondente: e-mail: juacyara@eq.ufrj.br, \\ sobral@eq.ufrj.br, rnyalmeida@gmail.com, \\ biaquintaes@yahoo.com.br,danielebilauerj@gmail.com
}

\section{RESUMO}

Substâncias Húmicas (SH) são definidas como polímeros amorfos, de massa molar elevada, estruturas complexas e heterogêneas, que alteram com frequência as suas conformações em função das interações que ocorrem entre os grupos funcionais presentes na sua estrutura. A presença dessas substâncias principalmente nos lixiviados de aterros de resíduos sólidos e, em maior quantidade, em lixiviados de aterros antigos, dificulta o tratamento dos lixiviados, devido ao alto grau de recalcitrância de tal matéria orgânica. Nesse estudo, dois métodos de quantificação de SH foram testados em dois lixiviados gerados em aterros do Estado do Rio de Janeiro, oriundos do Aterro Controlado de Gericinó (ACG) e o Aterro Metropolitano de Gramacho (AMG), assim como o seu fracionamento nas frações Ácidos Húmicos (AH) e Ácidos Fúlvicos (AF). Os resultados de SH foram, respectivamente, 616 e $608 \mathrm{mg} \mathrm{L}^{-1}$ para o lixiviado proveniente do ACG e 1182 e $1191 \mathrm{mg} \mathrm{L}^{-1}$ para o lixiviado proveniente do AMG. O lixiviado oriundo do ACG apresentou 33\% (201 mg L $\left.{ }^{-1}\right)$ de AH e $67 \%$ (411 $\left.\mathrm{mg} \mathrm{L}^{-1}\right)$ de $\mathrm{AF}$ e o de AMG apresentou 37\% (437 $\left.\mathrm{mg} \mathrm{L}^{-1}\right)$ de $\mathrm{AH}$ e $63 \%$ (741 $\left.\mathrm{mg} \mathrm{L}^{-1}\right)$ de AF.

Palavras-chave: ácidos fúlvicos, ácidos húmicos, matéria orgânica recalcitrante.

\section{Analysis of quantification methodologies for humic substances in leachates from solid waste landfills}

\begin{abstract}
Humic substances (HS) are defined as amorphous polymers, with high molecular weight and complex and heterogeneous structures that frequently change their configurations depending on the interactions between the functional groups present in their structures. The presence of these substances, particularly in landfill leachates and in greater quantities in
\end{abstract}


leachates from old landfills, hinders the treatment of leachate due to the high degree of recalcitrance of organic matter. In this study, two quantification methods were tested for two leachates generated in solid waste landfills located in Rio de Janeiro State: the Gericinó Controlled Landfill Gericinó (GCL) and the Gramacho Metropolitan Landfill (GML). The study also analyzed the fractionation of humic substances in fractions of Humic acids (HA) and fulvic acids (FA). The results of the quantification of HS were, respectively, 616 and 608 $\mathrm{mg} \mathrm{L}^{-1}$ for the leachate from GCL and 1182 and $1191 \mathrm{mg} \mathrm{L}^{-1}$ for leachate from GML. The leachate from GCL presented $33 \%\left(201 \mathrm{mg} \mathrm{L}^{-1}\right)$ of HA and $67 \%\left(411 \mathrm{mg} \mathrm{L}^{-1}\right)$ of FA and the leachate from GML presented $37 \%\left(437 \mathrm{mg} \mathrm{L}^{-1}\right)$ of HA and $63 \%\left(741 \mathrm{mg} \mathrm{L}^{-1}\right)$ of FA.

Keywords: fulvic acids, humic acids, recalcitrant organic matter.

\section{INTRODUÇÃO}

A maioria das substâncias orgânicas presentes em aterros de resíduos é degradada na forma de gases compostos principalmente de metano $\left(\mathrm{CH}_{4}\right)$ e dióxido de carbono $\left(\mathrm{CO}_{2}\right)$, enquanto algumas substâncias orgânicas refratárias são estabilizadas nos aterros ou removidas dos mesmos sob a forma de lixiviado (Castilhos Jr., 2006). Em lixiviados de aterros jovens, a maior parte do carbono orgânico está presente como ácidos graxos voláteis. No entanto, em aterros maduros, substâncias húmicas $(\mathrm{SH})$ dominam a fração orgânica de lixiviados provenientes de aterros onde predomina a fase metanogênica em até 60\% (Šir et al., 2012).

As substâncias húmicas podem ser definidas como uma série de polímeros amorfos de coloração amarela-marrom a preta, de massa molar relativamente alta, formados por reações de oxidação e subsequente polimerização da matéria orgânica, durante o processo de decomposição de resíduos vegetais e animais presentes no ambiente (Brum, 2005). Apresentam-se como uma mistura heterogênea de moléculas polidispersas com elevadas massas molares e grupos funcionais distintos contendo oxigênio na forma de carboxilas, hidroxilas fenólicas e carbonilas (Christensen et al., 1998).

Os compostos orgânicos refratários encontrados nos lixiviados são compostos principalmente por substâncias húmicas, que incluem ácidos húmicos $(\mathrm{AH})$, ácidos fúlvicos (AF) e huminas (Kjeldsen et al., 2002).

As composições médias de unidades básicas para os ácidos húmicos e fúlvicos, em termos de fórmulas químicas, são respectivamente, $\mathrm{C}_{187} \mathrm{H}_{186} \mathrm{O}_{89} \mathrm{~N}_{9} \mathrm{~S}_{2}$ e $\mathrm{C}_{135} \mathrm{H}_{182} \mathrm{O}_{95} \mathrm{~N}_{5} \mathrm{~S}_{2}$ (Schnitzer e Khan, 1978). No nível estrutural, as três frações húmicas são análogas, diferindo na massa molar e na quantidade de grupos funcionais (Kawahigashi, 2012).

As SH interagem facilmente com espécies metálicas e alguns compostos orgânicos, podendo aumentar a solubilidade de compostos hidrofóbicos e solubilizar metais através de complexação, modificando a biodisponibilidade e biotoxicidade de compostos poluentes presentes nos aterros (Christensen et al., 1998).

Numerosos instrumentos analíticos e abordagens têm sido aplicadas à análise de $\mathrm{SH}$, incluindo a espectroscopia de fluorescência (Antunes e Silva, 2005), de ressonância magnética nuclear (Peuravuori e Pihlaja, 2003), cromatografia de exclusão de tamanho de alto desempenho (Chin et al., 1994) e de espectrometria de massa (Mugo et al., 2007). Essas metodologias são sensíveis e precisas, contudo são métodos com maior custo operacional e que levam mais tempo em operação que métodos que utilizam avaliação espectrofotométrica, o que aumenta a necessidade de se buscar metodologias sensíveis, viáveis economicamente e de fácil execução para a análise quantitativa das substâncias húmicas do lixiviado, principalmente para empresas que tratam os lixiviados.

Um dos principais problemas relacionados ao gerenciamento de resíduos sólidos é o tratamento efetivo dos lixiviados produzidos nos aterros, visto que essa matriz é complexa e 
contém elevada concentração de matéria orgânica recalcitrante de difícil degradação: as substâncias húmicas. Nesse contexto, se faz necessário o estudo de metodologias de quantificação, identificação e remoção das SH para avaliar a eficiência dos tratamentos convencionais.

A recalcitrância da matéria orgânica e a cor adquirida nos lixiviados de aterros de resíduos tornam a quantificação de substâncias húmicas uma importante etapa de caracterização para a escolha do método mais adequado de tratamento de lixiviado.

Assim, este estudo teve como objetivo avaliar a utilização de dois métodos de quantificação de SH mais simples que os instrumentos analíticos que já são utilizados, e seu posterior fracionamento, e aplicá-los a dois lixiviados de diferentes origens, provenientes do Aterro Controlado de Gericinó (ACG) e do Aterro Metropolitano de Gramacho (AMG), localizados no Estado do Rio de Janeiro.

\section{MATERIAIS E MÉTODOS}

\subsection{Lixiviados em estudo}

Neste trabalho foram utilizados lixiviados de dois diferentes aterros do Estado do Rio de Janeiro: o Aterro Controlado de Gericinó (ACG) e o Aterro Metropolitano de Gramacho (AMG). No período de três anos, entre 2012 e 2015, foram coletadas seis amostras de cada lixiviado nas lagoas de estabilização localizadas nos próprios aterros.

O Aterro Controlado de Gericinó, situado no bairro de Bangu, no município do Rio de Janeiro, começou suas operações em 1987, como vazadouro a céu aberto. Recebia, em média, 2000 toneladas de resíduos sólidos urbanos por dia, gerando cerca de $500 \mathrm{~m}^{3} \mathrm{~d}^{-1}$ de lixiviado, armazenados na lagoa de acumulação existente (Costa et al., 2015). O ACG estava em fase de fechamento durante a coleta das amostras, em 2014.

O mais antigo dentre os aterros selecionados, o Aterro Metropolitano de Gramacho, está situado no município de Duque de Caxias. Segundo Campos et al. (2013), o aterro, aberto em 1978 operou como um lixão, teve suas atividades encerradas em junho de 2012, recebendo durante quase 35 anos a maior parte dos resíduos sólidos do município do Rio de Janeiro, ou seja, cerca de 9500 t de resíduos por dia. Ainda segundo os autores, mesmo após o encerramento do aterro, ele ainda produz, a cada dia, entre $1000 \mathrm{~m}^{3}$ e $2000 \mathrm{~m}^{3}$ de lixiviado.

São duas matrizes diferenciadas, visto que o lixiviado produzido no ACG apresenta contribuição de um aterro antigo (27 anos), fechado, que recebeu apenas resíduos urbanos e, o lixiviado produzido no AMG, apresenta contribuição de um aterro antigo (35 anos), fechado, que recebeu resíduo urbano, químico hospitalar e industrial (Campos et al., 2013) enquanto estava em operação.

A caracterização dos lixiviados foi realizada com base nos seguintes parâmetros físico-químicos, suas respectivas metodologias analíticas e equipamentos (APHA, 2005): Absorvância em $254 \mathrm{~nm}$ - Abs 254, que fornece uma indicação do conteúdo de matéria orgânica aromática (Método 5910-B, Shimadzu UV mini 1240), Carbono Orgânico Total - COT (Método 5310-C, TOC Analyzer - Hipertoc 1000), Cor (Método 2120-C, Espectrofotômetro DR2800 e reator Hach), Demanda Química de Oxigênio - DQO (Método 5220-D, Espectrofotômetro DR2800 e reator Hach) e pH (Método 4500-B, pHmetro microprocessador Quimis).

\subsection{Quantificação de Substâncias Húmicas}

\section{Método de Sheng Modificado}

O método espectrofotométrico/colorimétrico original foi desenvolvido por Sheng et al. (2007) e aplicado para determinar a concentração de substâncias húmicas em águas naturais. 
Š́r et al. (2012) modificaram essa metodologia a fim de quantificar as substâncias húmicas presentes em lixiviados provenientes de aterros de resíduos. O método de Sheng modificado se baseia na ligação do corante azul de toluidina (AT) a moléculas de ácidos húmicos para produzir um complexo que provoca a diminuição da absorbância a $603 \mathrm{~nm}$. A fórmula molecular do AT é $\mathrm{C}_{15} \mathrm{H}_{16} \mathrm{ClN}_{3} \mathrm{~S}$ e sua fórmula estrutural é ilustrada na Figura 1.<smiles></smiles>

Figura 1. Fórmula estrutural do corante Azul de Toluidina (AT). Fonte: Sheng et al. (2007).

Aos tubos de vidro de $10 \mathrm{~mL}$ foram adicionados $1 \mathrm{~mL}$ da solução de AT 1,5 mmol L $\mathrm{m}^{-1}$, 2,5 mL da solução de citrato-fosfato de sódio $0,05 \mathrm{~mol} \mathrm{~L}^{-1}(\mathrm{pH} 7,0)$ e $0,5 \mathrm{~mL}$ da solução de EDTA $0,05 \mathrm{~mol} \mathrm{~L}^{-1}$, esse último reagente visando à remoção de cátions potencialmente interferentes (por exemplo: $\mathrm{Ca}^{2+}, \mathrm{Mg}^{2+} \mathrm{e} \mathrm{Fe}^{3+}$ ). Em seguida, $4 \mathrm{~mL}$ de água destilada ou de amostras de lixiviado foram adicionados, e os tubos foram deixados à temperatura ambiente por 20 min antes da medição de absorbância, em espectrofotômetro (HACH), em $603 \mathrm{~nm}$. A água destilada foi utilizada como referência.

A concentração de SH em função da absorbância foi determinada com base na equação da reta de linearização da curva padrão para $\mathrm{SH}$, empregando padrões de $20,40,60 \mathrm{mg} \mathrm{L}^{-1}$, preparados com ácido húmico comercial, a partir da solução estoque de concentração $2 \mathrm{~g} \mathrm{~L}^{-1}$, pH 8,0, armazenada a $4^{\circ} \mathrm{C}$, no escuro. $\mathrm{O}$ cálculo para determinação de $\mathrm{SH}$, foi realizado utilizando-se a Equação 1.

$$
\Delta \mathrm{A}=\mathrm{A}_{0}-\mathrm{A}
$$

em que:

$\Delta \mathrm{A}=$ Absorbância real da amostra;

$\mathrm{A}=$ Absorbância do ensaio com amostra adicionada; $\mathrm{e}$

$\mathrm{A}_{0}=$ Absorbância do ensaio em branco de reagente, ou seja, com água destilada.

Foram realizados ensaios com a adição de padrão interno (Pi) preparado com ácido húmico comercial - AHc - (Sigma Aldrich), nas amostras de lixiviado e nas mesmas concentrações utilizadas na curva padrão de $\mathrm{SH}$ : 20, 40, $60 \mathrm{mg} \mathrm{L}^{-1}$. As amostras de lixiviados foram diluídas 10 e 20 vezes em água destilada de modo a ajustar à curva padrão.

Foi calculada a recuperação (Equação 2) para avaliar a quantidade medida da substância em relação à quantidade adicionada na matriz (ou branco), em um determinado número de testes (Burns et al., 2002).

$$
\mathrm{R}(\%)=\left(\mathrm{C}_{1}-\mathrm{C}_{2}\right) / \mathrm{C}_{3} \times 100
$$

em que:

$$
\begin{aligned}
& \mathrm{R}=\text { Recuperação }(\%) ; \\
& \mathrm{C}_{1}=\text { concentração na amostra adicionada (lixiviado + padrão); } \\
& \mathrm{C}_{2}=\text { concentração na amostra não adicionada (lixiviado); e }
\end{aligned}
$$




$$
\mathrm{C}_{3}=\text { concentração adicionada (padrão) }
$$

\section{Método de Lowry Modificado}

A determinação da concentração de substâncias húmicas nas amostras de lixiviado também foi realizada utilizando-se metodologia baseada no método de Lowry para proteínas (Frolund et al., 1995). Os autores modificaram essa metodologia a fim de quantificar as substâncias húmicas presentes em lodos biológicos. Essa modificação foi possível pois as substâncias húmicas, assim como as proteínas, reagem com o reagente Folin utilizado reduzindo-o, devido aos grupos fenólicos presentes. O método consiste na execução do método de Lowry com e sem a adição de $\mathrm{CuSO}_{4}$, em que a interferência da cor no ensaio sem a adição de $\mathrm{CuSO}_{4}$ é atribuída principalmente às substâncias húmicas (Moravia et al., 2011).

O princípio do método baseia-se em uma mistura contendo molibdato, tungstato e ácido fosfórico (reagente Folin Ciocalteau), que sofre uma redução ao reagir com proteínas, em meio alcalino e na presença do catalisador $\mathrm{Cu}^{+2}$, produzindo um composto azul escuro, com absorção máxima de $750 \mathrm{~nm}$. A absorbância desse composto, obtido após a redução do reagente de Folin, pode ser medida a $750 \mathrm{~nm}$, com elevada sensibilidade para baixas concentrações de substâncias húmicas, ou a $550 \mathrm{~nm}$, com baixa sensibilidade para elevadas concentrações de substâncias húmicas. Nesse procedimento, são utilizadas seis soluções:

- A (20g Na $\mathrm{CO}_{3}$ e 4g NaOH em 1000 mL $\mathrm{H}_{2} \mathrm{O}$ destilada);

- B (2,0g $\mathrm{CuSO}_{4} .5 \mathrm{H}_{2} \mathrm{O}$ em $100 \mathrm{~mL} \mathrm{H}_{2} \mathrm{O}$ destilada);

- $\mathrm{C}\left(2,0 \mathrm{~g} \mathrm{KNaC}_{4} \mathrm{H}_{4} \mathrm{O}_{6} \cdot 4 \mathrm{H}_{2} \mathrm{O}\right.$ em $100 \mathrm{~mL}$ de $\mathrm{H}_{2} \mathrm{O}$ destilada);

- D com cobre" (1 mL da solução B, $1 \mathrm{~mL}$ da solução C e $98 \mathrm{~mL}$ da solução A);

- D sem cobre"'(1 mL da solução C e 99 mL da solução A); e

- Folin $1 \mathrm{~mol} \mathrm{~L}^{-1}$ (diluir o reagente Folin-Ciocalteau na proporção 1:2 com água destilada).

Para se determinar o teor de SH foi diluída, em 10 vezes, a amostra de lixiviado em água destilada (volume utilizado $0,5 \mathrm{~mL}$ ) de modo a ajustar à curva padrão. Em seguida, foram adicionados $5 \mathrm{~mL}$ de solução "D com cobre" em cada tubo de ensaio para os ensaios com cobre; e $5 \mathrm{~mL}$ de solução "D sem cobre" para os ensaios sem cobre, e os tubos permaneceram em repouso por 10 minutos à temperatura ambiente.

Posteriormente, acrescentou-se 0,5 mL da solução de Folin 1:2 e, passados 30 minutos, foi feita a leitura das absorbâncias no espectrofotômetro nos comprimentos de onda $550 \mathrm{~nm}$, para concentração de $\mathrm{SH}$ maior que $25 \mathrm{mg} \mathrm{L}^{-1}$, e $750 \mathrm{~nm}$ para concentração de $\mathrm{SH}$ na faixa de 5 a $25 \mathrm{mg} \mathrm{L}^{-1}$.

Visando à adequação do ensaio para o efluente em estudo, a concentração de substâncias húmicas em função da absorbância foi determinada com base na reta de linearização da curva padrão para $\mathrm{SH}$, empregando padrões de $0,17,52$ e $101 \mathrm{mg} \mathrm{L}^{-1}$, preparados com ácido húmico comercial (Moravia et al., 2011). Em seguida, é calculada a absorbância dissociada ou corrigida de SH para cada amostra com cobre e sem cobre, pelo uso da Equação 3.

$$
A_{S H}=\left(A_{s / C u}-\left(F \times A_{c / C u}\right)\right) /(1-F)
$$

em que:

$\mathrm{A}_{\mathrm{SH}}=$ Absorbância para SH;

$\mathrm{F}=$ Fator de redução de absorbância $(\mathrm{F}=0,12$, nesse estudo);

$\mathrm{A}_{\mathrm{s} / \mathrm{Cu}}=$ absorbância sem a adição $\mathrm{CuSO}_{4} ; \mathrm{e}$ 
$\mathrm{A}_{\mathrm{c} / \mathrm{Cu}}=$ absorbância com a adição $\mathrm{CuSO}_{4}$.

O Fator de redução de absorbância (F) é calculado pelo uso da Equação 4.

$$
\mathrm{F}=\left(\mathrm{A}_{\mathrm{s} / \mathrm{Cu}}\right) /\left(\mathrm{A}_{\mathrm{c} / \mathrm{Cu}}\right)
$$

Foi utilizado a adição de padrão interno (Pi) preparado com ácido húmico comercial, nas mesmas concentrações utilizadas na curva padrão de SH: $17,51,102 \mathrm{mg} \mathrm{L}^{-1}$. As amostras de lixiviados foram diluídas 10 e 20 vezes em água destilada de modo à ajustar a curva padrão.

A recuperação foi calculada segundo a Equação 2 (Burns et al., 2002).

\subsection{Fracionamento de substâncias húmicas}

Com o objetivo de investigar as características da matéria orgânica recalcitrante presente em lixiviados de aterros de resíduos e o quanto essas substâncias recalcitrantes contribuem para a sua complexidade, foi realizado o fracionamento das substâncias húmicas.

A matéria orgânica recalcitrante presente no lixiviado foi separada em frações $\mathrm{AH}, \mathrm{AF}$ e Hyi (fração Não Húmica) usando o método descrito por Christensen et al. (1998). A fração $\mathrm{AH}$ foi precipitada por ajuste do $\mathrm{pH}$ do lixiviado para inferior a $1 \mathrm{e}$, em seguida, foi separada por centrifugação (Q222TM104, Quimis) a 50 rpm durante 5 minutos e filtração através de uma membrana de nitrato de celulose de 0,45 $\mu \mathrm{m}$ (Sartorius Stedim). Depois, o AH foi redissolvido em $0,05 \mathrm{~mol} \mathrm{~L}^{-1}$ de $\mathrm{NaOH}$.

A resina XAD-8 (Supelco Analytical) foi utilizada para reter o AF por adsorção. O AF retido foi separado por eluição com uma solução de $0,1 \mathrm{~mol} \mathrm{~L}^{-1}$ de $\mathrm{NaOH}$. A matéria orgânica dissolvida residual foi considerada como fração hidrofílica (Hyi) ou não húmica. As concentrações das frações AH e AF foram calculadas utilizando o método de quantificação de Sheng modificado, pois este é mais simples de execução e apresenta menor tempo operacional.

\section{RESULTADOS E DISCUSSÃO}

\subsection{Caracterização físico-química dos lixiviados em estudo}

A Tabela 1 ilustra os resultados da caracterização físico-química dos lixiviados dos ACG e AMG utilizados neste estudo.

Tabela 1. Caracterização físico-química dos lixiviados provenientes dos ACG e AMG (n=6).

\begin{tabular}{|c|c|c|c|c|c|c|}
\hline \multirow{2}{*}{ Parâmetros } & \multicolumn{3}{|c|}{ ACG } & \multicolumn{3}{|c|}{ AMG } \\
\hline & Mínimo & Máximo & Média & Mínimo & Máximo & Média \\
\hline Absorbância 254 nm & 11 & 21 & 14 & 21 & 30 & 25 \\
\hline Cor $\left(\mathrm{mgPtCo} \mathrm{L}^{-1}\right)$ & 4977 & 5679 & 5241 & 5643 & 8197 & 7332 \\
\hline $\operatorname{COT}\left(\mathrm{mgC} \mathrm{L}^{-1}\right)$ & 437 & 648 & 555 & 815 & 1297 & 972 \\
\hline $\mathrm{DQO}\left(\mathrm{mgO}_{2} \mathrm{~L}^{-1}\right)$ & 978 & 1813 & 1515 & 1776 & 2194 & 1998 \\
\hline $\mathrm{pH}$ & 7,7 & 8,6 & 8,1 & 7,9 & 8,8 & 8,3 \\
\hline
\end{tabular}

Pode-se observar que embora haja variação nas características dos lixiviados, a concentração de matéria orgânica é elevada, o pH está na faixa básica e há presença de matéria orgânica aromática. A absorbância em $254 \mathrm{~nm}$ tem sido usada para avaliar a remoção de compostos orgânicos em processos de tratamento de águas e efluentes (APHA, 2005).

Segundo Castilho Jr. et al. (2006), as concentrações de DQO tendem a sofrer reduções ao longo da degradação dos resíduos aterrados. Entretanto, essa redução pode ser lenta devido à presença de elevadas concentrações de matéria orgânica de difícil degradação. Ainda segundo 
os autores, essas são características comuns em lixiviados mais estabilizados, provenientes de aterros mais antigos, como é o caso dos aterros estudados, que possuem maior quantidade de compostos recalcitrantes, que resistem à biodegradação e tendem a persistir e se acumular no ambiente.

\subsection{Avaliação da Concentração das Substâncias Húmicas}

A curva padrão de $\mathrm{AH}$ obteve um coeficiente de correlação $\left(\mathrm{R}^{2}\right)$ de 0,999 . A concentração de SH em função da absorbância medida foi determinada com base na equação da reta de linearização da curva padrão para SH para o método de Sheng Modificado (Equação 5).

$$
\mathrm{SH}=(\Delta \mathrm{A}-0,2327) / 0,0009
$$

em que:

$\mathrm{SH}=$ concentração de $\mathrm{SH}\left(\mathrm{mg} \mathrm{L}^{-1}\right)$; e

$\Delta \mathrm{A}=$ absorbância real da amostra.

A Tabela 2 ilustra os resultados de recuperação do método de Sheng modificado e a concentração de SH presentes nos lixiviados oriundos dos aterros ACG e AMG.

As amostras de lixiviados foram diluídas 10 vezes e 20 vezes, em água destilada, de modo a se ajustarem à curva padrão. Em menores (5 vezes) ou maiores diluições (40 vezes) a concentração de substâncias húmicas não se ajustou à curva padrão construída, ou seja, nessas diluições a concentração de substâncias húmicas é muito alta ou muito baixa para ser corretamente medida pelo método. As diluições foram necessárias para ajustar a concentração das SH à faixa linear da curva de calibração.

O lixiviado gerado no AMG apresenta concentrações de $\mathrm{SH}$ mais elevadas do que o lixiviado gerado no ACG porque o AMG recebeu resíduos urbanos e industriais, enquanto estava em operação. Dentro deste contexto, Zamora e Morais (2005), Souto e Povinelli (2007), Foo e Hameed (2009) afirmam que a composição e a concentração de contaminantes nos lixiviados são influenciadas pelo tipo de resíduos descartados e pela idade do aterro. Os autores enfatizam ainda que um lixiviado cuja composição deriva de um aterro maduro é mais complexo que um lixiviado composto a partir de uma nova operação de descarga, apresentando elevadas concentrações de ácidos húmicos e fúlvicos e de baixa biodegradabilidade.

A Tabela 3 ilustra os resultados de recuperação do método de Lowry Modificado e a concentração de $\mathrm{SH}$ presentes nos lixiviados oriundos dos aterros ACG e AMG.

Os resultados de concentração de SH mostrados na Tabela 4, para diluição de 20 vezes, tem desvio padrão mais elevado do que os resultados para a diluição de 10 vezes, tanto Gericinó $(0,98 \%$ e $1,96 \%)$ como para Gramacho $(4,187 \%$ e 5,08\%). Todos os resultados de recuperação estão dentro de um intervalo aceitável. O lixiviado oriundo do Aterro Metropolitano de Gramacho apresenta concentrações de SH mais elevadas que o lixiviado do aterro de Gericinó, $1191 \mathrm{mg} \mathrm{L}^{-1}$ e $607,5 \mathrm{mg} \mathrm{L}^{-1}$, respectivamente, o que era esperado devido às características dos resíduos dispostos nos aterros.

Os resultados de quantificação de SH obtidos para os dois diferentes métodos avaliados foram bem semelhantes (Tabelas 2 e 3). Isto mostra que os métodos, apesar de se basearem em diferentes princípios, são adequados para a análise quantitativa de $\mathrm{SH}$ presentes nos lixiviados em estudo. Além disso, são metodologias sensíveis, econômicas e de fácil execução, mostrando-se viáveis no gerenciamento de aterros e estações de tratamento de lixiviados.

As principais limitações operacionais dos métodos avaliados são relativas ao intervalo de 
validade da curva-padrão construída com a solução de ácido húmico da Sigma Aldrich. Para o método de Sheng é de 0 a $60 \mathrm{mg} \mathrm{L}^{-1}$ de ácido húmico e para o método de Lowry, até $100 \mathrm{mg} \mathrm{L}^{-1}$ de ácido húmico. A vantagem do método de Sheng é que apresenta etapas mais simples e menor tempo de execução.

Tabela 2. Concentração de SH nas amostras dos lixiviados oriundos dos aterros de ACG e AMG, pelo método Sheng modificado $(\mathrm{n}=6)$.

\begin{tabular}{|c|c|c|c|}
\hline Identificação das Amostras & $\mathrm{SH}\left(\mathrm{mg} \mathrm{L}^{-1}\right)$ & Desvio* $(\%)$ & Recuperação (\%) \\
\hline ACG Diluída 10x & 614,00 & 5,15 & - \\
\hline ACG Diluída 10x + 20 mgAHc L ${ }^{-1}$ & 634,44 & 1,72 & 102 \\
\hline ACG Diluída 10x + 40 mgAHc L ${ }^{-1}$ & 653,33 & 4,01 & 98 \\
\hline ACG Diluída 10x + 60 mgAHc L ${ }^{-1}$ & 673,33 & 3,42 & 99 \\
\hline ACG Diluída 20x & 618,00 & 7,57 & - \\
\hline ACG Diluída $20 x+20$ mgAHc L ${ }^{1}$ & 637,78 & 3,36 & 99 \\
\hline ACG Diluída 20x + 40 mgAHc L ${ }^{-1}$ & 655,56 & 3,81 & 94 \\
\hline ACG Diluída 20x + 60 mgAHc L ${ }^{-1}$ & 677,78 & 6,72 & 100 \\
\hline AMG Diluída 10x & 1181,00 & 1,10 & - \\
\hline AMG Diluída $10 x+20$ mgAHc $\mathrm{L}^{-1}$ & 1202,11 & 2,91 & 105 \\
\hline AMG Diluída $10 \mathrm{x}+40 \mathrm{mgAHc} \mathrm{L}^{-1}$ & 1220,00 & 2,29 & 98 \\
\hline AMG Diluída 10x + 60 mgAHc L ${ }^{-1}$ & 1242,22 & 1,27 & 102 \\
\hline AMG Diluída 20x & 1184,00 & 2,54 & - \\
\hline AMG Diluída $20 x+20$ mgAHc $L^{-1}$ & 1205,44 & 3,36 & 102 \\
\hline AMG Diluída $20 \mathrm{x}+40 \mathrm{mgAHc} \mathrm{L}^{-1}$ & 1222,22 & 5,54 & 96 \\
\hline AMG Diluída $20 x+60$ mgAHc L ${ }^{-1}$ & 1244,00 & 5,08 & 100 \\
\hline
\end{tabular}

Nota: Desvio $=\left(\sum(\text { valor }- \text { média dos valores })^{2} /(\text { número de amostras }-1)\right)^{1 / 2}$.

$\mathrm{AHc}=$ ácido húmico comercial.

Para o método de Sheng modificado, os resultados de recuperação estão dentro de um intervalo acima de $90 \%$. Os desvios padrão apresentam valores relativamente baixos, e esse comportamento repetiu-se para as diferentes diluições (10x e 20x) e para as diferentes concentrações de padrões internos utilizadas, o que aumenta a confiabilidade no método e nos resultados.

Para o método de Lowry modificado, a curva padrão de AH obteve um coeficiente de correlação de 0,9998. A concentração de SH em função da absorbância foi determinada com base na equação da reta de linearização da curva padrão para SH (Equação 6).

$$
\mathrm{SH}=10 \times(\mathrm{A}-0,0056) / 0,0006
$$

em que:

$\mathrm{SH}=$ concentração de $\mathrm{SH}\left(\mathrm{mg} \mathrm{L}^{-1}\right)$; e

$\mathrm{A}=$ absorbância da amostra. 
Tabela 3. Concentração de SH nas amostras dos lixiviados oriundos dos aterros de ACG e AMG, pelo método Lowry modificado $(\mathrm{n}=6)$.

\begin{tabular}{|c|c|c|c|}
\hline Identificação das Amostras & $\mathrm{SH}\left(\mathrm{mg} \mathrm{L}^{-1}\right)$ & Desvio* $(\%)$ & Recuperação (\%) \\
\hline ACG Diluída 10x & 608,00 & 0,98 & - \\
\hline ACG Diluída 10x + 20 mgAHc L ${ }^{-1}$ & 626,74 & 3,48 & 94 \\
\hline ACG Diluída 10x + 40 mgAHc L $\mathrm{L}^{-1}$ & 647,76 & 3,43 & 99 \\
\hline ACG Diluída 10x + 60 mgAHc L $\mathrm{L}^{-1}$ & 667,27 & 0,06 & 99 \\
\hline ACG Diluída 20x & 607,00 & 1,96 & - \\
\hline ACG Diluída $20 x+20$ mgAHc $L^{1}$ & 631,96 & 3,93 & 125 \\
\hline ACG Diluída 20x + 40 mgAHc L ${ }^{-1}$ & 649,69 & 5,08 & 107 \\
\hline ACG Diluída 20x + 60 mgAHc L ${ }^{-1}$ & 670,53 & 6,89 & 106 \\
\hline AMG Diluída 10x & 1192,00 & 4,18 & - \\
\hline AMG Diluída $10 x+20$ mgAHc L $L^{-1}$ & 1213,48 & 5,10 & 107 \\
\hline AMG Diluída 10x + 40 mgAHc L $\mathrm{L}^{-1}$ & 1232,80 & 4,18 & 102 \\
\hline AMG Diluída 10x + 60 mgAHc $L^{-1}$ & 1252,50 & 4,38 & 101 \\
\hline AMG Diluída 20x & 1190,00 & 5,08 & - \\
\hline AMG Diluída $20 x+20$ mgAHc L $L^{-1}$ & 1212,12 & 6,89 & 111 \\
\hline AMG Diluída 20x + 40 mgAHc L $\mathrm{L}^{-1}$ & 1234,47 & 6,97 & 111 \\
\hline AMG Diluída 20x + 60 mgAHc L $\mathrm{L}^{-1}$ & 1251,13 & 6,60 & 102 \\
\hline
\end{tabular}

Nota: Desvio $=\left(\sum(\text { valor }- \text { média dos valores })^{2} /(\text { número de amostras }-1)\right)^{1 / 2}$.

$\mathrm{AHc}=$ ácido húmico comercial.

\subsection{Fracionamento de Substâncias Húmicas}

Os resultados do fracionamento das substâncias húmicas presentes nos lixiviados estudados encontram-se na Tabela 4. Ressalta-se que as frações de AH e AF nos lixiviados em estudo foram quantificadas apenas pelo método de Sheng modificado, sendo esse método de execução mais rápida quando comparado ao método de Lowry modificado.

Tabela 4. Fracionamento das $\mathrm{SH}$ dos lixiviados provenientes dos aterros ACG e AMG (n=6).

\begin{tabular}{lrr}
\hline Fração & ACG & AMG \\
\hline $\mathrm{SH}\left(\mathrm{mg} \mathrm{L}^{-1}\right)$ & 616 & 1182 \\
$\mathrm{AH}\left(\mathrm{mg} \mathrm{L}^{-1}\right)$ & $201(33 \%)$ & $437(37 \%)$ \\
$\mathrm{AF}\left(\mathrm{mg} \mathrm{L}^{-1}\right)$ & $411(67 \%)$ & $741(63 \%)$ \\
\hline
\end{tabular}

A caracterização das SH e suas frações em amostras de lixiviado de diferentes origens pode facilitar o desenvolvimento de uma capacidade de previsão do comportamento das SH de acordo com a idade do aterro.

Em estudos realizados por Christensen et al. (1998), os autores concluíram que, da fração de matéria orgânica recalcitrante, os ácidos húmicos e fúlvicos são responsáveis por aproximadamente 40 e $60 \%$, respectivamente. Essa afirmação foi confirmada em estudos 
posteriores realizados por Huo et al. (2008), onde os autores encontraram concentrações de 30 a $40 \%$ de $\mathrm{AH}$ e de 60 a $70 \%$ de $\mathrm{AF}$ em lixiviados estabilizados, provenientes de aterros maduros. Esses resultados estão de acordo com os obtidos no presente trabalho.

A investigação das características da matéria orgânica presente em lixiviados de aterros de resíduos nas formas de frações húmicas e fúlvicas pode auxiliar a entender melhor o nível de recalcitrância presente no lixiviado: quanto maior a preponderância de substâncias húmicas em relação às fúlvicas, mais resistente à biodegradação será o lixiviado. A partir dessa informação, consegue-se estabelecer um sistema de tratamento de lixiviado mais adequado.

\section{CONCLUSÕES}

Os resultados de quantificação de SH nos lixiviados, com os métodos de Sheng e Lowry modificados, respectivamente, foram $616 \mathrm{mg} \mathrm{L}^{-1}$ e $608 \mathrm{mg} \mathrm{L}^{-1}$ para Gericinó e $1182 \mathrm{mg} \mathrm{L}^{-1} \mathrm{e}$ $1191 \mathrm{mg} \mathrm{L}^{-1}$ para Gramacho, mostrando 1,4\% de desvio para aterro de Gericinó e 0,72\% para o aterro de Gramacho.

Os métodos utilizados neste estudo são simples, rápidos e sensíveis, tem baixo consumo de amostra, são economicamente viáveis e de fácil execução para a análise quantitativa de SH em lixiviados. Os resultados de recuperação foram superiores a 90\% para os lixiviados em estudo. Estes fatores dão confiabilidade na utilização desses métodos de quantificação.

Em relação às frações húmicas encontradas, para ambos aterros, a fração $\mathrm{AH}$ variou na faixa de $33-37 \%$, enquanto que a fração fúlvica variou na faixa de 63-67\%.

\section{REFERÊNCIAS}

AMERICAN PUBLIC HEALTH ASSOCIATION - APHA. Standard Methods for the Examination of Water and Wastewater. 21. ed. Washington, 2005.

ANTUNES, M. C. G.; SILVA, J. Multivariate curve resolution analysis excitation-emission matrices of fluorescence of humic substances, Analytica Chimica Acta, v. 546, n. 1, p. 52-59, 2005. http://dx.doi.org/10.1016/j.aca.2005.05.003

BRUM, M. C. Remoção de ácido húmico da água por precipitação e flotação com a utilização de surfatantes catiônicos. 2005. 61f. Dissertação (Mestrado em Engenharia Metalúrgica e de Materiais) - COPPE, Universidade Federal do Rio de Janeiro, Rio de Janeiro, 2005.

BURNS, D. T.; DANZER, K.; TOWNSHEND, A. Use of the term "recovery" and "apparent recovery" in analytical procedures. Pure and Applied Chemistry, v. 74, n. 11, p. 2201-2205, 2002. https://doi.org/10.1351/pac200274112201

CAMPOS, J. C.; MOURA, D.; COSTA, A. P.; YOKOYAMA, L.; ARAUJO, F. V. F.; CAMMAROTA, M. C. Evaluation of $\mathrm{pH}$, alkalinity and temperature during air stripping process for ammonia removal from landfill leachate. Journal of Environmental Science and Health, Part A: Toxic/Hazardous Substances and Environmental Engineering, v. 48, n. 9, p. 1105-1113, 2013. http://dx.doi.org/10.1080/10934529.2013.774658

CASTILHOS JR., A. B. Gerenciamento de resíduos sólidos urbanos com ênfase na proteção de corpos d'água: prevenção, geração e tratamento de lixiviados de aterros sanitário. In: CASTILHOS JR., A. B. (Org.). Resíduos sólidos urbanos: aterro sustentável para municípios de pequeno porte. Rio de Janeiro: Rima/ABES, 2006. p. 494. 
CHIN, Y. P.; GSCHWEND, P. M. The abundance, distribution, and configuration of porewater organic colloids in recent sediments. Geochimica et Cosmochimica Acta, v. 55, n. 5, p. 1309-1317, 1994. http://dx.doi.org/10.1016/0016-7037(91)90309-S

CHRISTENSEN, J. B.; JENSEN, D. L.; GRON, C.; FILIP, Z.; CHRISTENSEN, T. H. Characterization of the dissolved organic carbon in landfill leachate-polluted groundwater. Water Research, v. 32, n. 1, p. 125-135, 1998. http://dx.doi.org/10.1016/S0043-1354(97)00202-9

COSTA, F. M.; CAMPOS, J. C.; FONSECA, F. V.; BILA, D. M. Tratamento de lixiviados de aterros de resíduos sólidos utilizando Processos Fenton e Foto-Fenton Solar. Revista Ambiente \& Água, v. 10, n. 1, p. 109-110, 2015. http://dx.doi.org/10.4136/ambiagua. 1483

FROLUND, B.; GRIEBE, T.; NIELSEN, P. H. Enzymatic activity in the activated-sludge floc matrix. Applied Microbiology and Biotechnology, v. 43, n. 4, p. 755 - 761, 1995.

FOO, K. Y.; HAMEED, B. H. An overview of landfill leachate treatment via activated carbon adsorption process. The Journal of Hazardous Materials, v. 171, p. 54-60, 2009. http://dx.doi.org/10.1016/j.jhazmat.2009.06.038

HUO, S.; XI, B.; YU, H; HE, L.; FAN, S.; LIU, H. Characteristics of dissolved organic matter (DOM) in leachate with diferent landfill ages. Journal of Environmental Sciences, v. 20, n. 4, p. 492-498, 2008. http://dx.doi.org/10.1016/S1001-742(08)62085-9

KAWAHIGASHI, F. Aplicabilidade do pós-tratamento de lixiviado de aterro sanitário por adsorção em carvão ativado granular e avaliação ecotoxicológica. 2012. 155p. Dissertação (Mestrado de Edificações e Saneamento) - Centro de Tecnologia e Urbanismos, Universidade Estadual de Londrina, Londrina, 2012.

KJELDSEN, P. I.; BARLAZ, M. A.; ROOKER, A. P.; BAUN, A.; LEDIN, A.; CHRISTENSEN, T. H. Present and long-term composition of MSW landfill leachate: a review. Environmental Science and Technology, v. 32, n. 4, p. 297-336, 2002. http://dx.doi.org/10.1080/10643380290813462

MORAVIA, W. G.; LANGE, L. C.; AMARAL, M. C. S. Avaliação de processo oxidativos avançado pelo reagente de Fenton em condições otimizadas no tratamento de lixiviado de aterro sanitário com ênfase em parâmetros coletivos e caracterização do lodo gerado. Química Nova, v. 34, n. 8, p. 1370-1377, 2011. http://dx.doi.org/10.1590/S010040422011000800014

MUGO, S.; GETHI, M.; OKURO, J.; BERGVINSON, D.; GROOTE, H. D.; SONGA, J. Evaluation of stem borer resistant maize open pollinated varieties and hybrids on-station and on-farm in the moist mid-altitude maize ecologies of Kenya. In: AFRICAN CROP SCIENCE SOCIETY CONFERENCE, 8., 2007, El-Minia. Papers... El-Minia: Minia University, 2007. p. 959-964

PEURAVUORI, J. P.; PIHLAJA, K. Critical comments on accuracy of quantitative determination of natural humic matter by solid state CNMR spectroscopy. Talanta, v. 59, n. 1, p. 177-189, 2003. http://dx.doi.org/10.1016/S0039-9140(02)00476-9

SCHNITZER, M.; KHAN, S. U. Soil organic matter. Amsterdam: Elsevier, 1978. 319p. 
SHENG, G. P.; ZHANG, M. L.; YU, H. Q. A rapid quantitative method for humic substances determination in natural waters. Analytica Chimica Acta, v. 592, n. 2, p. 162-167, 2007. http://dx.doi.org/10.1016/j.aca.2007.04.024

ŠIR, M.; PODHOLA, M.; PATOCKA, T.; HONZAJKOVA, Z.; KOCUREK, P.; KUBAL, M. et al. The effect of humic acids on the reverse osmosis treatment of hazardous landfill leachate. Journal of Hazardous Materials, v. 207, p. 86-90, 2012. http://dx.doi.org/10.1016/j.jhazmat.2011.08.079

SOUTO, G. B.; POVINELLI, J. Varacterísticas do lixiviado de aterros sanitários no Brasil. In: CONGRESSO BRASILEIRO DE ENGENHARIA SANITÁRIA E AMBIENTAL, 24., 2007, Belo Horizonte. Anais... Belo Horizonte: ABES, 2007.

TATSI, A. A.; ZOUBOULIS, A. I.; MATIS, K. A.; SAMARAS, P. Coagulation-flocculation pre-treatment of sanitary landfill lichgates. Chemosphere, v. 53, p. 737-744, 2003. http://dx.doi.org/10.1016/S0045-6535(03)00513-7

TRAN, N. H.; NGO, H. H.; URASE, T.; GIN, K. Y. A critical review on characterization strategies of organic matter for wastewater and water treatment processes. Bioresource Technology, v. 193, p. 523-533, 2015. http://dx.doi.org/10.1016/j.biortech.2015.06.091

ZAMORA, P.; MORAIS, J. L. Use of advanced oxidation processes to improve the biodegradability of mature landfill leachates. Journal of Hazardous Materials, v. 123, n. 1/3, p. 181-186, 2005. http://dx.doi.org/10.1016/j.jhazmat.2005.03.041

ZOUBOULIS, A. I.; CHAI, X.; KATSOYIANNIS, I. A. The application of bioflocculant for the removal of humic acids from stabilized landfill leachates. Journal of Environmental Management, v. 70, n. 1, p. 35-41, 2004. http://dx.doi. org/10.1016/j.jenvman.2003.10.003 


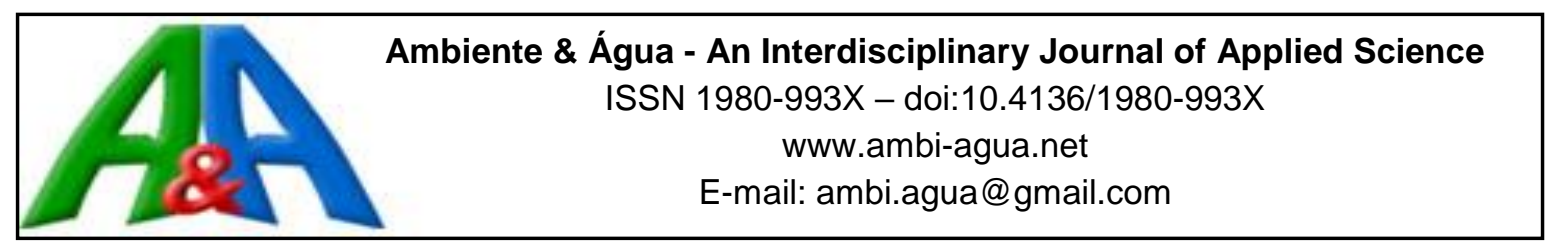

\title{
Vegetação arbustivo-arbórea em uma restinga de Jaguaruna, litoral sul do Estado de Santa Catarina, Brasil
}

\author{
doi:10.4136/ambi-agua.1952 \\ Received: 06 Jun. 2016; Accepted: 29 Oct. 2016 \\ Robson dos Santos; Guilherme Alves Elias*; \\ Aline Votri Guislon; Iara Zaccaron Zanoni \\ Universidade do Extremo Sul Catarinense (UNESC), Criciúma, SC, Brasil \\ Programa de Pós-Graduação em Ciências Ambientais, Herbário Pe. Dr. Raulino Reitz (CRI) \\ *Autor correspondente: e-mail: guilherme@unesc.net, \\ rsa@unesc.net,vg_aline@hotmail.com,iara_zanoni@hotmail.com
}

\section{RESUMO}

Para ampliar o conhecimento sobre a planície costeira do Estado de Santa Catarina, foi realizado um estudo fitossociológico do componente arbustivo-arbóreo na restinga da Lagoa do Arroio Corrente, no município de Jaguaruna, sul do Estado. Para amostragem da vegetação, foi usado o método de parcelas, incluindo os indivíduos com diâmetro a altura do solo (DAS) mínimo de $2,5 \mathrm{~cm}$. Constatou-se, diferença de altura na fitofisionomia do trecho superior $(5 \mathrm{~m})$ e do trecho inferior $(10 \mathrm{~m})$ das dunas, optando-se por realizar a amostragem separadamente. A vegetação da restinga da Lagoa do Arroio Corrente apresentou, no trecho superior, estratificação de baixo porte $(1$ a $5 \mathrm{~m})$, destacando-se indivíduos arbustivos, conferindo aparência densa à vegetação, devido ao desenvolvimento aglomerado dessas plantas e, no trecho inferior, com indivíduos arbóreos emergentes, conferindo dois estratos, um mais baixo com predomínio de vegetação arbustiva $(2$ a $5 \mathrm{~m})$ e um segundo com indivíduos arbóreos (até $10 \mathrm{~m}$ ). A riqueza florística resultou em 17 famílias, 25 gêneros e 32 espécies. A área basal total foi de 4,3 $\mathrm{m}^{2}$.ha $\mathrm{a}^{-1}$ (trecho superior) e $23,2 \mathrm{~m}^{2}$.ha' $\mathrm{h}^{-1}$ (trecho inferior). Guapira opposita (Vell.) Reitz apresentou maior valor de importância, destacando-se também nos demais parâmetros fitossociológicos analisados (frequência, densidade e dominância). As análises efetuadas contribuem com dados estruturais para as restingas de Santa Catarina, podendo auxiliar na caracterização da vegetação dos cordões arenosos do sul do Brasil.

Palavras-chave: biodiversidade, fitossociologia, Floresta Atlântica, vegetação litorânea.

\section{Shrub-tree vegetation in a restinga of Jaguaruna, southern coast of Santa Catarina, Brazil}

\begin{abstract}
In order to develop a greater understanding of the coastal land of the state of Santa Catarina, we carried out a phytosociological study of shrub-tree component in the restinga of the Lagoa do Arroio Corrente, in the municipality of Jaguaruna, in the southern part of the state. The study used the "plots" method, including shrub-trees with a diameter at soil height
\end{abstract}


(DSH) minimum of $2.5 \mathrm{~cm}$. We found a difference in the height of shrub-trees individuals in the upper $(10 \mathrm{~m})$ and lower $(5 \mathrm{~m})$ sections, and opted to carry out sampling in these two vegetation types separately. The restinga's vegetation of the Lagoa do Arroio Corrente had, in the upper section, low size stratification (1 to $5 \mathrm{~m}$ ), due to shrubby individuals, with dense vegetation cover, due to the development of clusters of plants and, in the lower section, with emerging individual trees, resulting in two strata: a lower stratum, with predominance of shrubby (2 to 5) and an upper stratum, with tree individuals (up to $10 \mathrm{~m}$ ). The floristic richness resulted in 17 botanical families, 25 genera and 32 species. The total basal area was $4.3 \mathrm{~m}^{2} \cdot \mathrm{ha}^{-1}$ (upper section) and $23.2 \mathrm{~m}^{2} \cdot \mathrm{ha}^{-1}$ (lower section). Guapira opposita (Vell.) Reitz exhibited the highest importance value, with other outstanding phytosociological parameters (frequency, density, and dominance). The analyses performed contribute to structural data for restingas of Santa Catarina, assisting in the characterization of vegetation of sand bars of Southern Brazil.

Keywords: Atlantic Forest, biodiversity, coastal vegetation, phytosociology.

\section{INTRODUÇÃO}

A vegetação da restinga no sul do Brasil possui características peculiares, e reúne um conjunto de ecossistemas com alta heterogeneidade ambiental, ocorrendo desde dunas até planícies costeiras. As condições ambientais, nas restingas, são extremas, com altas temperaturas, ventos constantes, elevada salinidade e solos com deficiência em nutrientes (Scarano et al., 2001). No entanto, a vegetação estabelecida nestes ambientes apresenta adaptabilidade e resistência, compondo um ecossistema com função de proteção da costa e da biodiversidade (Sevegnani e Comtois, 2013; Sevegnani et al., 2013). Mesmo apresentando tal importância, a restinga tem sofrido recorrentes impactos, principalmente, pela introdução de espécies animais e vegetais exóticas, pela pressão agrícola e pelo crescimento das cidades (Santos et al., 2012).

Muitos são os papéis da vegetação de restinga sobre o ecossistema onde está inserida. Alguns autores associam essa vegetação à estabilização do substrato nesses ambientes, como a proteção da ação de ventos, que é considerada importante modificador da paisagem (Lindeman, 1906; Rambo, 1954; Assumpção e Nascimento, 2000; Santos et al., 2012), além de manter a drenagem natural, contribuindo também para a preservação da fauna endêmica e migratória (Falkenberg, 1999; Rocha et al., 2005).

A restinga apresenta uma diversidade fisionômica que expressa uma composição, que geralmente, combina espécies próprias do litoral com outras provenientes de outros ecossistemas, como por exemplo, do bioma Mata Atlântica, e é representada por espécies aclimatadas à faixa litorânea (Araujo, 2000; Sacramento et al., 2007; IBGE, 2012), no entanto, podem ocorrer variações fenotípicas devido à diferença do habitat original (Freire, 1990; Leite e Klein, 1990; Scarano, 2002; Klein et al., 2007).

Para melhor conhecimento das restingas são necessárias descrições sobre a vegetação que se pode dar, basicamente, por meio de métodos florísticos e estruturais (Kent e Coker, 1992; Santos et al., 2012). Dessa forma, a listagem da flora e a caracterização estrutural contribuem para designar e classificar as vegetações litorâneas, além de diferenciar suas fisionomias (Silva e Britez, 2005; Magnago et al., 2011; Melo Júnior et al., 2015), fornecendo mais características sobre as restingas de Santa Catarina.

Em Santa Catarina, estudos florísticos e fitossociológicos que destacam a importância e diversidade da restinga, já foram tratados por Reitz (1954, 1961), Bresolin (1979), Falkenberg (1999), Korte et al. (2013) e Melo Júnior et al. (2015).

Salienta-se que, no sul do estado de Santa Catarina, há poucos estudos sobre a vegetação 
de restinga, sendo, portanto, de grande importância à produção científica sobre este tipo de ecossistema, uma vez que, constantemente vem sofrendo com as ações antrópicas (Cunha, 2005). Desta forma, diante da lacuna existente, este estudo teve como objetivo descrever as características estruturais do componente arbustivo-arbóreo de uma restinga no litoral sul do estado de Santa Catarina.

\section{MATERIAL E MÉTODOS}

O estudo foi realizado no componente arbustivo-arbóreo da restinga da Lagoa do Arroio Corrente, município de Jaguaruna, litoral sul do estado de Santa Catarina, com distância de 2 $\mathrm{km}$ do mar. O solo foi classificado, como Espodossolo (Embrapa, 2013). O clima é Cfa (segundo a classificação de Köppen), ou seja, mesotérmico úmido, sem estação seca definida e com verão quente (Alvares et al., 2013), com índices pluviométricos médios de $1.400 \mathrm{~mm}$ ao ano e umidade relativa do ar de $82 \%$ (Back, 2009), influenciado pela umidade marítima. A vegetação se desenvolve sobre dunas fixas de aproximadamente 30 metros de altura, tendo sua base em contato com a água da lagoa e foi descrita por Reitz (1961) como "lagoa de barragem".

Constatou-se, no reconhecimento da área de estudo, diferença de altura na fitofisionomia do trecho superior $(5 \mathrm{~m})$ e do trecho inferior $(10 \mathrm{~m})$ das dunas, optando-se por realizar a amostragem separadamente (Figura 1).

A vegetação da restinga da Lagoa do Arroio Corrente apresentou, no trecho superior, estratificação de baixo porte (1 a $5 \mathrm{~m}$ ), destacando-se indivíduos arbustivos, conferindo aparência densa à vegetação, devido ao desenvolvimento aglomerado dessas plantas e, no trecho inferior, com indivíduos arbóreos emergentes, conferindo dois estratos, um mais baixo com predomínio de vegetação arbustiva (2 a $5 \mathrm{~m}$ ) e um segundo, com indivíduos arbóreos (até $10 \mathrm{~m}$ ). A comparação entre os dois trechos foi feita por meio do índice de similaridade de Jaccard que expressa a semelhança entre ambientes, baseando-se no número de espécies comuns.

A atualização taxonômica seguiu a Lista das Espécies da Flora do Brasil (Flora do Brasil 2020 em construção, 2016). O material coletado fértil foi depositado no Herbário Pe. Dr. Raulino Reitz (CRI) da Universidade do Extremo Sul Catarinense (UNESC).

$\mathrm{O}$ estudo fitossociológico foi realizado empregando-se o método de parcelas, proposto por Mueller-Dombois e Ellenberg (2002). Foram traçadas em cada trecho da duna (superior e inferior) 30 parcelas de $5 \mathrm{~m} \times 5 \mathrm{~m}\left(750 \mathrm{~m}^{2}\right)$, distribuídas em três blocos de 10 parcelas contíguas, distantes 30 metros entre si e mensurados todos os indivíduos vivos com diâmetro a altura do solo (DAS) $\geq 2,5 \mathrm{~cm}$. O diâmetro das plantas foi obtido com o auxílio de paquímetro digital e a altura foi estimada com bastão graduado. Indivíduos ramificados no nível do solo foram considerados na amostragem quando, pelo menos, um dos ramos atendia ao critério de inclusão estabelecido (DAS $\geq 2,5 \mathrm{~cm}$ ), conforme descrito por Moro e Martins (2011), que orientam que, se no nível do solo, dois eixos aparecem conspicuamente ligados (rameta), tendo uma base comum, ambos são considerados como um único indivíduo. Já, quando cada eixo emerge separadamente no nível do solo (geneta), eles são considerados como indivíduos distintos e devem ser medidos separadamente.

Para análise da organização do componente arbustivo-arbóreo foi calculado a densidade, a frequência e a dominância absoluta, o valor de importância (VI), o índice de diversidade de Shannon-Wiener (H') e o índice de equabilidade de Pielou (J'). Foram elaborados histogramas do número de indivíduos por intervalos de altura (amplitude de um metro) e de diâmetro (amplitude de 2,5 cm). Foram consideradas como espécies raras aquelas representadas por apenas um indivíduo na amostragem (Martins, 1991). 


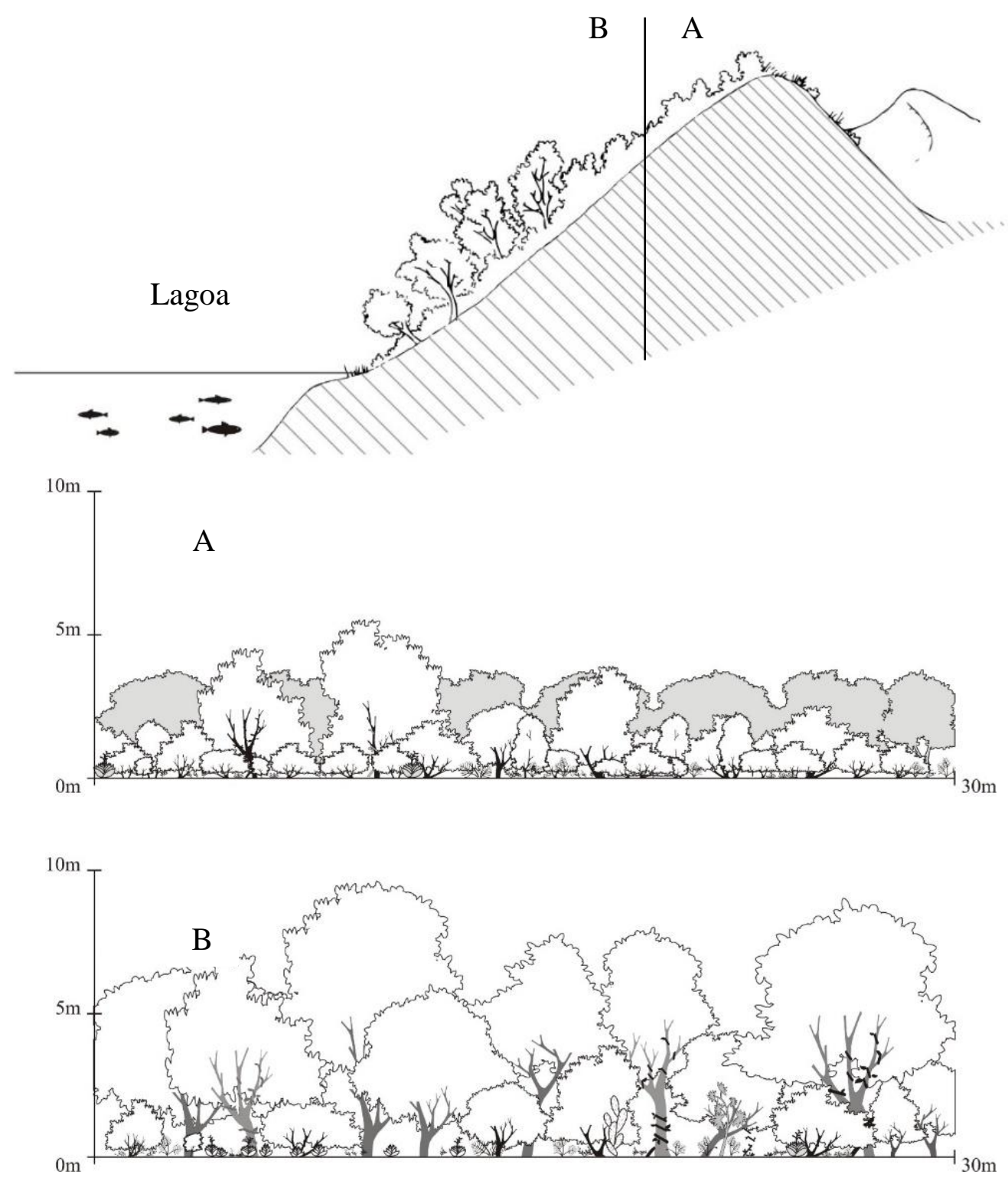

Figura 1. Perfil esquemático das fitofisionomias da restinga da Lagoa do Arroio Corrente, município de Jaguaruna, Santa Catarina. A = trecho superior e $\mathrm{B}=$ trecho inferior das dunas.

Aspectos das síndromes de dispersão das espécies arbustivo-arbóreas foram abordados e discutidos de acordo com van der Pijl (1972). Para esta análise, foram reunidas informações de cada espécie, principalmente as relativas ao tipo de fruto, com base em pesquisa bibliográfica e observações realizadas em campo.

Para o enquadramento das espécies nos grupos ecológicos, conforme proposto por Budowski (1965), consultou-se estudos realizados na região sul de Santa Catarina, bem como por observações feitas nos trabalhos de campo no momento da amostragem fitossociológica.

\section{RESULTADOS E DISCUSSÃO}

A composição florística foi representada por 32 espécies e 25 gêneros distribuídos em 17 famílias (Tabela 1), com maior número de espécies para Myrtaceae (cinco espécies), Aquifoliaceae e Euphorbiaceae com quatro espécies cada e Sapindaceae com três espécies. 
Essas quatro famílias representaram 50\% do total de espécies amostradas. Entre as demais famílias, três foram representadas por duas espécies cada (19\%) e dez por uma única espécie (31\%). A família com maior número de indivíduos foi Nyctaginaceae (52\%), seguida por Euphorbiaceae (13\%), Myrtaceae (6\%) e Lauraceae (4\%).

Tabela 1. Caracterização das fitofisionomias da restinga da Lagoa do Arroio Corrente, Jaguaruna, Santa Catarina. $\mathrm{DA}=$ densidade absoluta (indivíduos.ha ${ }^{-1}$ e DoA $=$ dominância absoluta $\left(\mathrm{m}^{2} \cdot \mathrm{ha}^{-1}\right)$, índice de diversidade de Shannon-Wiener $\left(\mathrm{H}^{\prime}\right)$, em nats.ind ${ }^{-1}$ e de equabilidade de Pielou (J').

\begin{tabular}{lcccccccc}
\hline \multirow{2}{*}{ Trecho } & \multirow{2}{*}{ Famílias } & \multirow{2}{*}{ Gêneros } & Espécies & DA & DoA & & \multicolumn{2}{c}{ Índice } \\
\cline { 1 - 3 } \cline { 8 - 10 } Superior & 12 & 16 & 18 & 1.425 & 4,3 & & 1,50 & 0,52 \\
Inferior & 15 & 23 & 27 & 2.732 & 23,2 & & 2,30 & 0,70 \\
\hline Total & $\mathbf{1 7}$ & $\mathbf{2 5}$ & $\mathbf{3 2}$ & $\mathbf{2 . 0 7 8}$ & $\mathbf{1 5 , 4}$ & & $\mathbf{2 , 6 7}$ & $\mathbf{0 , 7 0}$ \\
\hline
\end{tabular}

A família Myrtaceae, com riqueza superior às demais, geralmente permanece com representantes entre as cinco espécies de maior valor de importância, sobressaindo-se na composição florística e estrutural em diversos locais da costa brasileira (Silva et al., 2008; Scherer et al., 2005, 2009; Santos et al., 2012; Martins et al., 2013), além de suas espécies obterem, na restinga, um ambiente propício para seu desenvolvimento (Reitz, 1961).

A similaridade florística (50\%) evidenciou alta semelhança entre os dois trechos avaliados evidenciando existência de um padrão fitogeográfico baseado na distribuição das espécies. No trecho superior foram exclusivas as famílias Fabaceae e Lamiaceae, representadas por três espécies exclusivas, enquanto que no trecho inferior foram exclusivas as famílias Erythroxylaceae, Rosaceae, Sapindaceae e Sapotaceae, representadas por 13 espécies exclusivas (Tabela 2).

Tabela 2. Parâmetros fitossociológicos, ordenados por valor de importância (VI), das espécies amostradas no trecho superior e inferior das dunas da restinga da Lagoa do Arroio Corrente, Jaguaruna, Santa Catarina.

\begin{tabular}{llcccccc}
\hline \multicolumn{1}{c}{ Trecho Superior } & & & & & & \\
\hline \multicolumn{1}{c}{ Espécie } & Família & FA & DA & DoA & VI & SD & GE \\
\hline Guapira opposita (Vell.) Reitz & Nyctaginaceae & 76,7 & 960 & 2,82 & 59,0 & Zoo & Sin \\
Campomanesia littoralis D.Legrand & Myrtaceae & 10,0 & 40 & 0,47 & 6,5 & Zoo & Cli \\
Vitex megapotamica (Spreng.) Moldenke* & Lamiaceae & 13,3 & 80 & 0,12 & 5,4 & Zoo & Sin \\
Handroanthus pulcherrimus (Sandwith) Mattos & Bignoniaceae & 10,0 & 53 & 0,18 & 4,6 & Ane & Sin \\
Myrsine parvifolia A.DC.* & Primulaceae & 10,0 & 40 & 0,15 & 4,0 & Zoo & Sin \\
Lithrea brasiliensis Marchand & Anacardiaceae & 6,7 & 27 & 0,10 & 2,7 & Zoo & Pio \\
Myrsine umbellata Mart. & Primulaceae & 6,7 & 40 & 0,06 & 2,6 & Zoo & Sin \\
Psidium cattleianum Sabine & Myrtaceae & 6,7 & 27 & 0,06 & 2,4 & Zoo & Sta \\
Ilex paraguariensis A.St.-Hil. & Aquifoliaceae & 6,7 & 27 & 0,02 & 2,1 & Zoo & Pio \\
Sebastiania serrata Müll.Arg. & Euphorbiaceae & 3,3 & 27 & 0,03 & 1,5 & Aut & Pio \\
Casearia sylvestris Sw. & Salicaceae & 3,3 & 13 & 0,06 & 1,4 & Zoo & Sin \\
\hline Continua
\end{tabular}

Continua... 


\begin{tabular}{|c|c|c|c|c|c|c|c|}
\hline 10. & & & & & & & \\
\hline Sapium glandulosum (L.) Morong & Euphorbiaceae & 3,3 & 13 & 0,05 & 1,4 & Aut & Pio \\
\hline Enterolobium contortisiliquum (Vell.) Morong* & Fabaceae & 3,3 & 13 & 0,03 & 1,2 & Aut & Pio \\
\hline Myrcia splendens (Sw.) DC. & Myrtaceae & 3,3 & 13 & 0,03 & 1,2 & Zoo & Sin \\
\hline Ilex pseudobuxus Reissek* & Aquifoliaceae & 3,3 & 13 & 0,02 & 1,1 & Zoo & Pio \\
\hline Ocotea pulchella (Nees \& Mart.) Mez & Lauraceae & 3,3 & 13 & 0,02 & 1,1 & Zoo & Pio \\
\hline Pera glabrata (Schott) Poepp. ex Baill. & Peraceae & 3,3 & 13 & 0,02 & 1,1 & Zoo & Sta \\
\hline Condalia buxifolia Reissek & Rhamnaceae & 3,3 & 13 & 0,01 & 1,0 & Zoo & Pio \\
\hline Total & & 177 & 1425 & 4,3 & 100 & & \\
\hline ec & Inferior & & & & & & \\
\hline Espécie & Família & FA & DA & DoA & VI & $\mathrm{SD}$ & GE \\
\hline Guapira opposita (Vell.) Reitz & Nyctaginaceae & 76,7 & 1200 & 12,41 & 41,1 & Zoo & Sin \\
\hline Sapium glandulosum (L.) Morong & Euphorbiaceae & 33,3 & 280 & 3,62 & 12,4 & Aut & Pio \\
\hline $\begin{array}{l}\text { Allophylus edulis (A.St.-Hil. et al.) Hieron. ex } \\
\text { Niederl.* }\end{array}$ & Sapindaceae & 23,3 & 120 & 0,63 & 5,0 & Zoo & Sin \\
\hline Ocotea indecora (Schott) Mez* & Lat & 13,3 & 160 & 0,80 & 4,6 & Zoo & Cli \\
\hline Sebastiania serrata Müll.Arg. & Euphorbiaceae & 10,0 & 133 & 1,17 & 4,4 & Zoo & Sin \\
\hline Casearia sylvestris $\mathrm{Sw}$. & Salicaceae & 10,0 & 93 & 0,94 & 3,6 & Zoo & Sin \\
\hline Condalia buxifolia Reissek & Rha & 13,3 & 80 & 0,31 & 2,9 & Zoo & Pio \\
\hline Psidium cattleianum Sabine & Myrtaceae & 10,0 & 67 & 0,06 & 2,0 & Zoo & Sta \\
\hline Cupania vernalis Cambess.* & Sapindaceae & 10,0 & 53 & 0,17 & 2,0 & Zoo & Pio \\
\hline Ilex paraguariensis A.St.-Hil. & Aquifoliaceae & 10,0 & 67 & 0,04 & 2,0 & Zoo & Pio \\
\hline $\begin{array}{l}\text { Chrysophyllum marginatum (Hook. \& Arn.) } \\
\text { Radlk.* }\end{array}$ & Sapotaceae & 6,7 & 53 & 0,33 & 1,9 & Zoo & Pio \\
\hline Campomanesia littoralis D.Legrand & Myrt: & 6,7 & 53 & 0,29 & 1,8 & Zoo & Cli \\
\hline Lithrea brasiliensis Marchand & Anacardiaceae & 6,7 & 40 & 0,38 & 1,8 & Zoo & Pio \\
\hline Ilex theezans Mart. ex Reissek* & Aquifoliaceae & 6,7 & 40 & 0,17 & 1,5 & Zoo & Pio \\
\hline Ilex dumosa Reissek* & Aquifoliaceae & 6,7 & 27 & 0,27 & 1,5 & Zoo & Pio \\
\hline Myrsine umbellata Mart. & Primulaceae & 6,7 & 27 & 0,12 & 1,2 & Zoo & Sin \\
\hline Actinostemon concolor (Spreng.) Müll.Arg.* & Euphorbiaceae & 3,3 & 53 & 0,14 & 1,2 & Aut & Sta \\
\hline Pera glabrata (Schott) Poepp. ex Baill. & Peraceae & 6,7 & 27 & 0,10 & 1,2 & Zoo & Sta \\
\hline Matayba guianensis Aubl.* & Sapindaceae & 3,3 & 13 & 0,44 & 1,2 & Zoo & Sta \\
\hline Myrcia splendens (Sw.) DC. & Myrtaceae & 6,7 & 27 & 0,06 & 1,2 & Zoo & Sin \\
\hline Handroanthus pulcherrimus (Sandwith) Mattos & Bignoniaceae & 6,7 & 27 & 0,05 & 1,2 & Ane & Sin \\
\hline Erythroxylum deciduum A.St.-Hil.* & Erythroxylaceae & 3,3 & 27 & 0,16 & 0,9 & Zoo & Pio \\
\hline Myrcia palustris DC.* & Myrtaceae & 3,3 & 13 & 0,22 & 0,9 & Zoo & Pio \\
\hline Ocotea pulchella (Nees \& Mart.) Mez & Lauraceae & 3,3 & 13 & 0,17 & 0,8 & Zoo & Pio \\
\hline Eugenia catharinae O.Berg* & Myrtaceae & 3,3 & 13 & 0,13 & 0,7 & Zoo & Sin \\
\hline Prunus ulei Koehne* & Rosaceae & 3,3 & 13 & 0,01 & 0,5 & Zoo & Cli \\
\hline Schinus polygamus (Cav.) Cabrera* & Anacardiaceae & 3,3 & 13 & 0,01 & 0,5 & Zoo & Sin \\
\hline 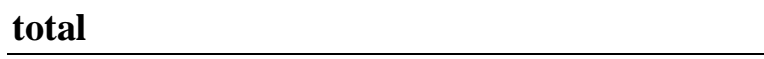 & & 297 & 2132 & 23,2 & 100 & & \\
\hline
\end{tabular}

Nota: $\mathrm{FA}=$ frequência absoluta $(\%), \mathrm{DA}=$ densidade absoluta (indivíduos.ha ${ }^{-1}$ ), DoA $=$ dominância absoluta $\left(\mathrm{m}^{2} \cdot \mathrm{ha}^{-1}\right)$; síndrome de dispersão $(\mathrm{SD})$, em que, $\mathrm{Zoo}=$ zoocoria, Ane $=$ anemocoria e Aut $=$ autocoria e grupo ecológico $(\mathrm{GE})$, em que, Pio= pioneira, $\mathrm{Sin}=$ secundária inicial, $\mathrm{Sta}=$ secundária tardia e $\mathrm{Cli}=$ clímax. *espécie exclusiva do trecho amostrado (superior ou inferior). 
A diferença na composição das espécies e do porte dos indivíduos, relacionada aos trechos superior e inferior das dunas, pode estar relacionada à maior fertilidade decorrente do acúmulo de matéria orgânica no trecho inferior, o que pode favorecer o aparecimento e o desenvolvimento de espécies que atribuem um aspecto diferencial na fitofisionomia, fato também observado em outros estudos da costa brasileira (Sampaio, 2005; Almeida Junior et al., 2011). Adicionalmente, os ventos em excesso, vindos do mar, contribuem com a fitofisionomia presente no trecho superior das dunas.

Apesar do tamanho reduzido do remanescente amostrado, a restinga da Lagoa do Arroio Corrente apresentou boa representatividade de espécies devido a maior riqueza quando comparada às demais áreas de mata arenosa amostradas no sul do Brasil (Scherer et al., 2009).

A espécie com maior valor de importância, tanto no trecho superior quanto no trecho inferior, foi Guapira opposita (Vell.) Reitz, destacando-se das demais também nos demais parâmetros fitossociológicos (frequência, densidade e dominância). Já as espécies consideradas raras, aquelas representadas por um único indivíduo, perfizeram $44 \%$ no trecho superior e $22 \%$ no trecho inferior (Tabela 2). Dentre estas, destaca-se Prunus ulei Koehne, no trecho inferior da duna, que consta na lista das espécies ameaçadas de extinção no estado de Santa Catarina (CONSEMA, 2014), descrita como característica e exclusiva das restingas arbustivas, apresentando possivelmente restrita, descontínua e inexpressiva dispersão, estendendo-se em Santa Catarina, desde Laguna até Sombrio (Reitz, 1996).

Guapira opposita é característica da floresta ombrófila densa e da restinga litorânea no sul do Brasil, onde apresenta vasta e expressiva dispersão, além de elevada abundância (Reitz, 1970). A espécie figura entre as dominantes do componente arbustivo, formando densos agrupamentos nos terrenos arenosos e pouco ondulados nas proximidades das praias (Reitz, 1970). Na restinga da Lagoa do Arroio Corrente, G. opposita faz parte da vegetação típica de dunas fixas, situadas mais para o interior e atrás das dunas móveis ou semifixas. Ocorre nas associações juntamente com Sapium glandulosum (L.) Morong, Allophylus edulis (A.St.-Hil. et al.) Hieron. ex Niederl., Ocotea indecora (Schott) Mez, Sebastania serrata Müll.Arg., Casearia sylvestris Sw., Campomanesia littoralis D.Legrand e Vitex megapotamica (Spreng.) Moldenke. Os altos valores de densidade obtidos por espécies de ampla distribuição refletem a elevada plasticidade ecológica dessas espécies e a sua capacidade de adaptação a ambientes estressantes.

A ocorrência de G. opposita, em diferentes ecossistemas, como na floresta ombrófila densa (Colonetti et al., 2009; Martins et al., 2013; Bosa et al., 2015) e na restinga (Santos et al., 2012), indica que a espécie apresenta plasticidade de caracteres morfológicos e fisiológicos, no sentido de que os filtros seletivos não restringiram seu estabelecimento e sobrevivência nos processos evolutivos. Uma vez que espécies com variação fenotípica têm maior habilidade para ocorrer ao longo de um gradiente de condições ambientais. A variação fenotípica de $G$. opposita possibilita seu estabelecimento em ambientes com diferentes intensidades luminosas, desde a restinga arbustiva até a restinga alta (Santos et al., 2010). Quando sombreados pelo dossel da floresta, a forma da copa mostra-se mais aberta, com muitas ramificações do caule, apresentando uma arquitetura de modo a constituir uma única camada coletora de luz. Nos indivíduos da restinga, expostos diretamente à luz, a forma da copa mostra-se mais fechada, também com muitas ramificações do caule, porém mostrando as folhas dispostas em diversas camadas coletoras de luz (Santos et al., 2010).

A altura média encontrada no componente arbustivo-arbóreo no trecho superior da duna foi $2,9 \mathrm{~m}$ e a máxima, $5,5 \mathrm{~m}$; no trecho inferior à altura média foi $4,9 \mathrm{~m}$ e a máxima $10 \mathrm{~m}$. A maioria dos indivíduos (92\%) no trecho superior foi registrada entre a segunda e a quinta classe de altura, correspondendo aos intervalos de 2 a $5 \mathrm{~m}$ (Figura 2); no trecho inferior, a maioria dos indivíduos (74\%) foi registrada entre a quarta e a sétima classe de altura, correspondendo aos intervalos de 3 a $7 \mathrm{~m}$ (Figura 2). 


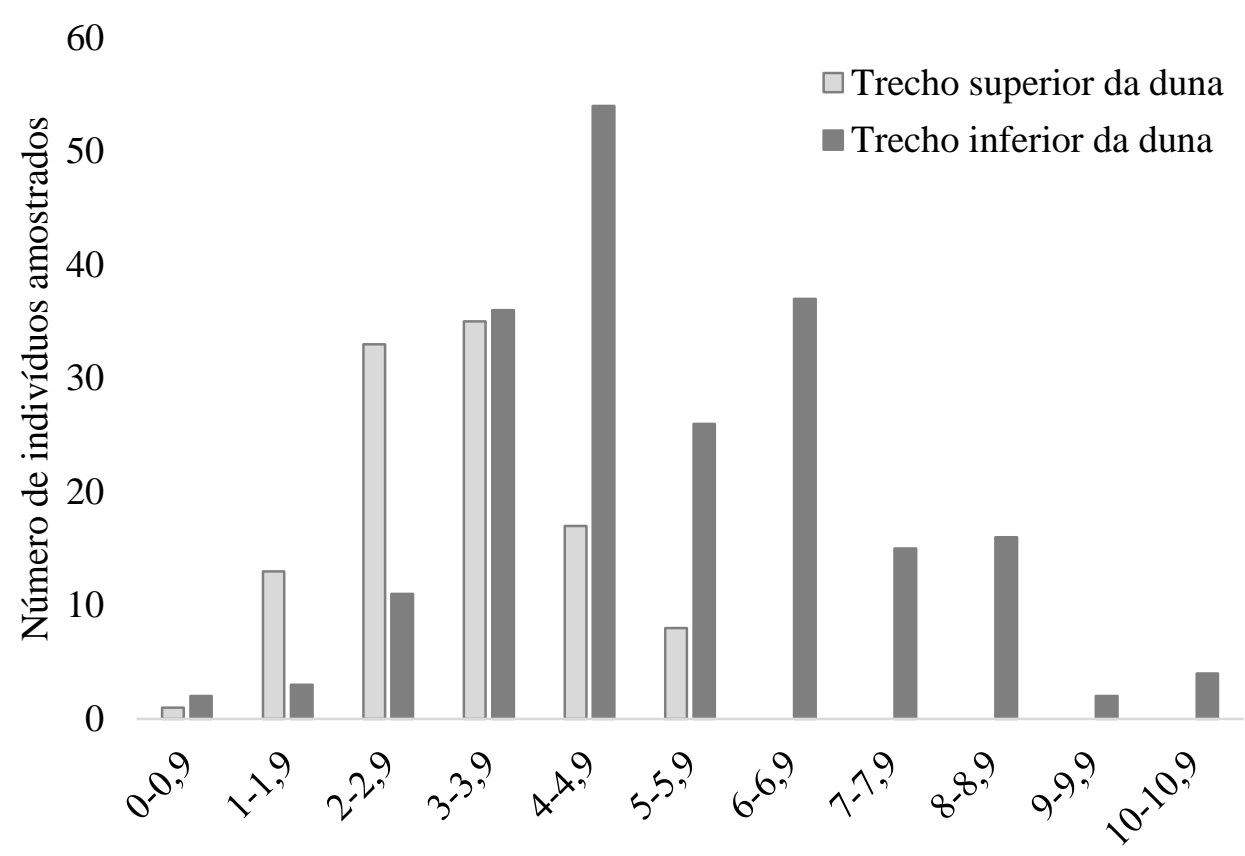

Classes de altura

Figura 2. Distribuição em classes de altura do componente arbustivo-arbóreo na restinga da Lagoa do Arroio Corrente, município de Jaguaruna, Santa Catarina, Brasil.

O diâmetro médio no trecho superior foi de $4,9 \mathrm{~cm}$ e o máximo de $15,5 \mathrm{~cm}$ e no trecho inferior o diâmetro médio foi de 7,3 cm e o máximo de $23,9 \mathrm{~cm}$, representados principalmente por indivíduos de Guapira opposita. A maioria dos indivíduos (62\%) no trecho superior foi registrada na primeira classe de diâmetro e no trecho inferior a maioria dos indivíduos (34\%) foi registrada na segunda classe de diâmetro, seguido pela terceira classe com $22 \%$. A área basal total foi de $4,3 \mathrm{~m}^{2} \cdot \mathrm{ha}^{-1}$ e $23,2 \mathrm{~m}^{2} \cdot \mathrm{ha}^{-1}$, nos trechos superior e inferior, respectivamente.

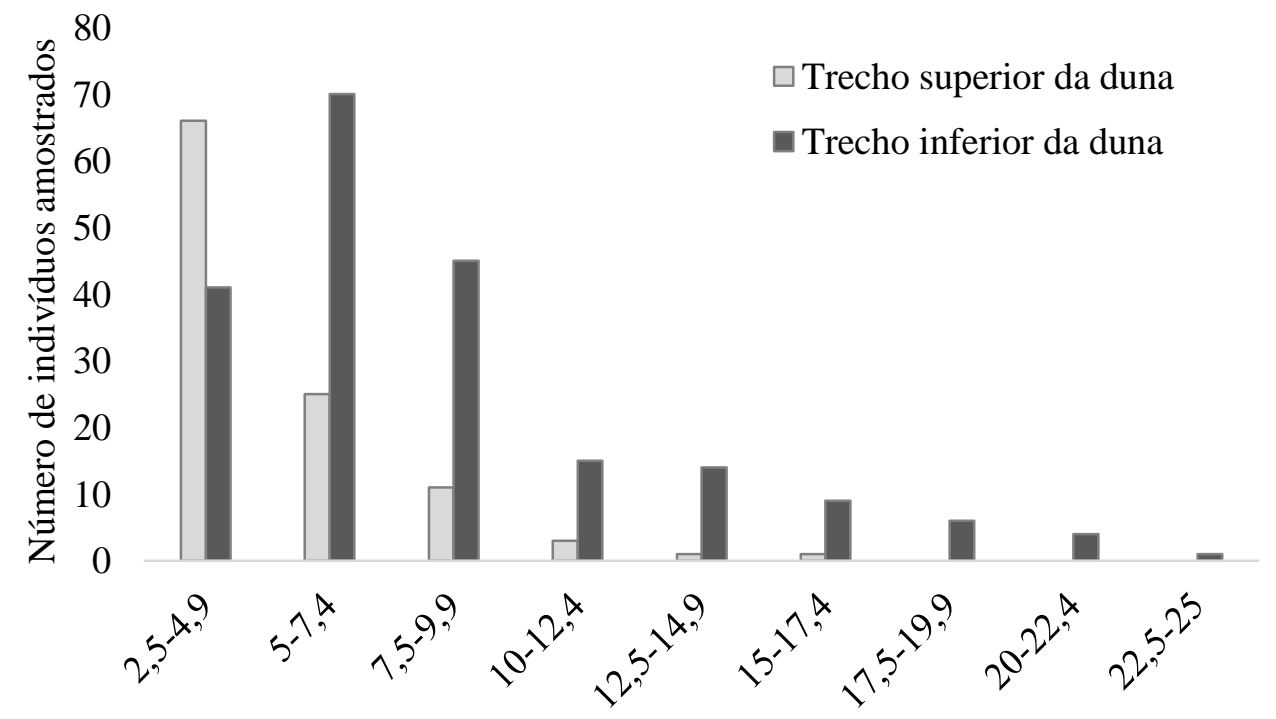

Classes de diâmetro

Figura 3. Distribuição em classes diamétricas do componente arbustivo-arbóreo na restinga da Lagoa do Arroio Corrente, município de Jaguaruna, Santa Catarina, Brasil. 
No trecho superior, ocorreu grande quantidade de indivíduos pequenos e finos e com muitas ramificações devido a pressões diferenciadas como luminosidade e ventos em excesso, além de baixos níveis de nutrientes (Sztutman e Rodrigues, 2002). Diferentemente, no trecho inferior, os indivíduos se apresentaram com diâmetros maiores (Figura 3).

Analisando o componente arbustivo-arbóreo em relação aos grupos ecológicos, das espécies encontradas no trecho superior, $83 \%$ foram classificadas como de início de sucessão (pioneiras + secundárias iniciais) e no trecho inferior foi de $76 \%$ (Figura 4).

A zoocoria representou, no trecho superior, $78 \%$ das espécies amostradas e no trecho inferior, 89\%. Esse padrão também foi identificado por outros autores (Scherer et al., 2005; Santos et al., 2012) no componente arbustivo-arbóreo de restinga arenosa. Esses estudos ratificam a importância dos agentes bióticos no fluxo gênico em restingas arenosas, assemelhando-se ao resultado de vários autores, como o mais relevante modo de dispersão das espécies lenhosas na Floresta Atlântica.

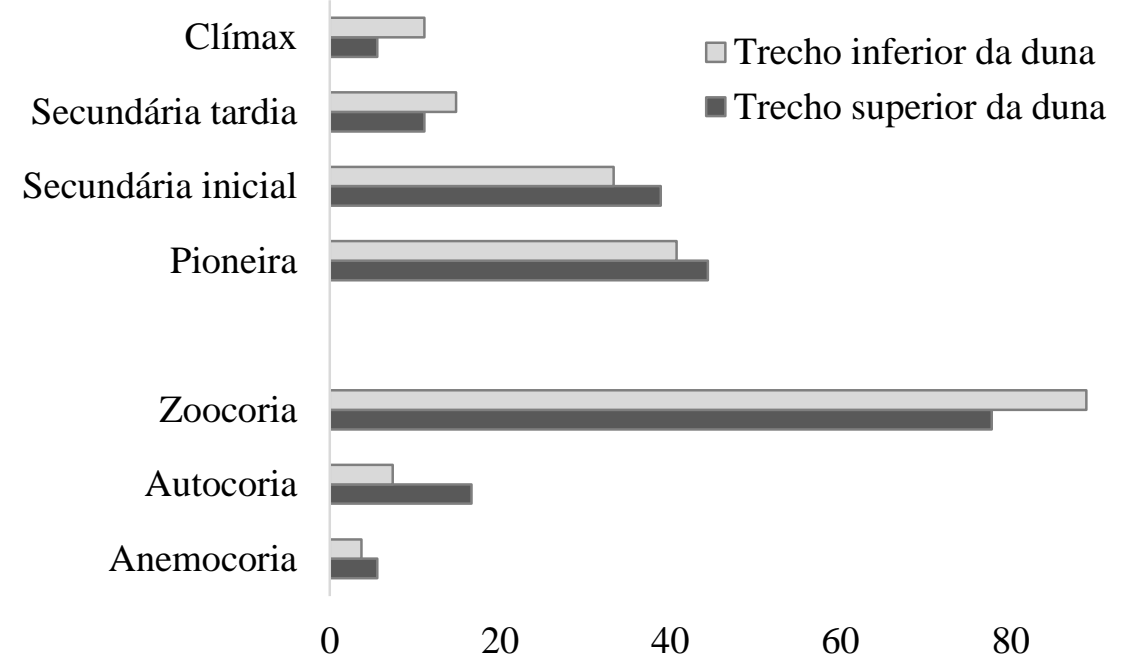

100

Figura 4. Distribuição (\%) em grupos ecológicos e em síndromes de dispersão das espécies do componente arbustivo-arbóreo na restinga da Lagoa do Arroio Corrente, município de Jaguaruna, Santa Catarina, Brasil.

\section{CONCLUSÃO}

A vegetação da restinga da Lagoa do Arroio Corrente apresentou, no trecho superior, estratificação de baixo porte, destacando-se as espécies arbustivas, apresentando aparência densa devido ao desenvolvimento aglomerado dessas plantas; e no trecho inferior, apresentou espécies arbóreas emergentes, conferindo dois estratos à vegetação, um mais baixo com predomínio de vegetação arbustiva e um segundo, com espécies arbóreas.

A heterogeneidade da vegetação de restinga não ficou evidenciada na restinga da Lagoa do Arroio Corrente, mesmo que, aparentemente, se reconheça pela altura dos indivíduos presentes, o reconhecimento de duas fitofisionomias distintas. Tal fato demonstra a complexidade a qual as comunidades vegetais de restinga apresentam, principalmente no que concerne aos diferentes condicionantes ambientais existentes no litoral brasileiro.

A espécie Guapira opposita possui a maior frequência, densidade e dominância, tanto no trecho superior, quanto no inferior, refletindo sua elevada plasticidade ecológica e a sua capacidade de adaptação a ambientes estressantes.

As análises efetuadas contribuíram com dados estruturais para as restingas de Santa Catarina, podendo auxiliar na caracterização da vegetação dos cordões arenosos do sul do 
Brasil.

As informações obtidas podem ser utilizadas para indicar espécies com potencialidades para restauração ecológica da mata ciliar no entorno da Lagoa do Arroio Corrente, já que é utilizada para abastecimento público e, no passado, sofreu impacto pela utilização em sua margem direita, para pastejo de gado bovino e para cultivo agrícola, atividades hoje proibidas.

\section{REFERENCIAS}

ALMEIDA JUNIOR, E. B.; SANTOS-FILHO, F. S.; ARAÚJO, E. L.; ZICKEL, C. S. Structural characterization of the woody plants in restinga of Brazil. Journal of Ecology and the Natural Environment, v. 3, n. 3, p. 95-103, 2011.

ALVARES, C. A.; STAPE, J. L.; SENTElHAS, P. C.; GONÇALVES, J. L. M.; SPAROVEK, G. Köppen's climate classification map for Brazil. Meteorologische Zeitschrift, v. 22, n. 6, p. 711-728, 2013. https://doi.org/10.1127/0941-2948/2013/0507

ARAUJO. D. S. D. Análise florística e fitogeográfica das restingas do estado do Rio de Janeiro. 2000. Tese (Doutorado em Ecologia) - Universidade Federal do Rio de Janeiro, Rio de Janeiro, 2000.

ASSUMPÇÃO, J.; NASCIMENTO, M. T. Estrutura e composição florística de quatro formações vegetais de restinga no complexo lagunar Grussaí/Iquipari, São João da Barra, RJ, Brasil. Acta botanica brasilica, v. 14, n. 3, p. 301-315, 2000. http://dx.doi.org/10.1590/S0102-33062000000300007

BACK, A. Caracterização climática. In: MILIOLI, G; SANTOS, R.; CITADINI-ZANETTE, V. Mineração de carvão, meio ambiente e desenvolvimento sustentável no sul de Santa Catarina. Curitiba: Juruá, 2009. p. 17-33.

BOSA, D. M.; PACHECO, D.; PASETTO, M. R.; SANTOS, R. Florística e estrutura do componente arbóreo de uma Floresta Ombrófila Densa Montana em Santa Catarina, Brasil. Revista Árvore, v. 39, n. 1, p.49-58, 2015. http://dx.doi.org/10.1590/010067622015000100005

BRESOLIN, A. Flora da restinga da ilha de Santa Catarina. Ínsula, n. 10, p. 1-55, 1979.

BUDOWSKI, G. N. Distribution of tropical American rain forest species in the light of succession processes. Turrialba, v. 15, n. 1, p. 40-42, 1965.

COLONETTI, S.; CITADINI-ZANETTE, V.; MARTINS, R.; SANTOS, R.; ROCHA, E.; JARENCOW, J. A. Florística e estrutura fitossociológica em floresta ombrófila densa submontana na barragem do rio São Bento, Siderópolis, Estado de Santa Catarina. Acta Scientiarum. Biological Sciences, v. 31, n. 4, p. 397-405, 2009. http://dx.doi.org/10.4025/actascibiolsci.v31i4.3345

CUNHA, I. Desenvolvimento sustentável na costa brasileira. Revista Galega de Economia, v 14, p. 1-14, 2005.

EMBRAPA. Empresa Brasileira de Pesquisa Agropecuária. Sistema brasileiro de classificação de solos. 3. ed. Brasília: EMBRAPA, 2013. 353 p.

FALKENBERG, D. B. Aspecto da flora e da vegetação secundária da Restinga de Santa Catarina, sul do Brasil. Insula, n. 28, p. 1-30, 1999. 
FREIRE, M. S. B. Levantamento florístico do parque estadual das dunas do natal. Acta botanica brasilica, v. 4, n. 2, suppl. 1, p. 41-59, 1990. http://dx.doi.org/10.1590/S010233061990000300006

IBGE. Instituto Brasileiro de Geografia e Estatística. Manual Técnico da Vegetação Brasileira. Rio de Janeiro: IBGE, 2012. 274 p.

JARDIM BOTÂNICO DO RIO DE JANEIRO. Lista de espécies da flora do Brasil. 2016. Disponível em: http://floradobrasil.jbrj.gov.br/. Acesso em: 10 maio 2016.

KENT, M.; COKER, P. Vegetation description and analysis. London: Belhaven Press, 1992. $363 \mathrm{p}$.

KLEIN, A. S.; CITADINI-ZANETTE, V.; SANTOS, R. Florística e estrutura comunitária de restinga herbácea no município de Araranguá, Santa Catarina. Biotemas, v. 20, n. 3, p. 15-26, 2007.

KORTE, A.; GASPER, A. L.; KRUGER, A.; SEVEGNANI, L. Composição florística e estrutura das restingas de Santa Catarina, In: VIBRANS, A. C.; SEVEGNANI, L.; GASPER, A. L.; LINGNER, D. V. Floresta Ombrófila Densa. Edifurb, Blumenau, 2013. p. 285-309.

LEITE, P. F.; KLEIN, R. M. Vegetação. In: IBGE. Geografia do Brasil: Região Sul. Rio de Janeiro, 1990. p. 113-150.

LINDEMAN, C. A. M. Vegetação no Rio Grande do Sul. Porto Alegre: Universal, 1906. $365 \mathrm{p}$.

MAGNAGO, L. F. S.; MARTINS, S. V.; PEREIRA, O. J. Heterogeneidade florística das fitocenoses de restingas nos estados do Rio de Janeiro e Espírito Santo, Brasil. Revista Árvore, v. $35, \quad$ n. 2, p. 245-254, 2011. http://dx.doi.org/10.1590/S010067622011000200009

MARTINS, F. R. Estrutura de uma floresta mesófila. Campinas: Ed. Unicamp, 1991. 246 p.

MARTINS, R.; JARENKOW, J. A.; GIEHL, E. L. H.; CITADINI-ZANETTE, V.; SANTOS, R. Estrutura de uma floresta brejosa em substrato turfoso, sul de Santa Catarina, Brasil. Revista Árvore, v. 37, n. 2, p. 299-309, 2013. http://dx.doi.org/10.1590/S010067622013000200011

MELO JÚNIOR, J. C. F.; BOEGER, M. R. T. Riqueza, estrutura e interações edáficas em um gradiente de restinga do Parque Estadual do Acaraí, Estado de Santa Catarina, Brasil. Hoehnea, v. 42, n. 2, p. 207-232, 2015.

MORO, M. F.; MARTINS, F. R. Métodos de levantamento do componente arbóreo-arbustivo. In: FELFILI, J. M.; EISENLOHR, P. V.; MELO, M. M. R. F.; ANDRADE, L. A.; MEIRA NETO, J. A. A. (Ed.) Fitossociologia no Brasil: Métodos e Estudos de Caso. Viçosa, Editora da Universidade Federal de Viçosa, 2011. p. 174-212.

MUELLER-DOMBOIS, D.; ELLENBERG, H. Aims and methods of vegetation ecology. New Jersey: The blackburn press, 2002. 547 p.

PEARMAN, P. B.; GUISAN, A.; BROENNIMANN, O.; RANDIN, C. F. Niche dynamics in space and time. Trends in Ecology and Evolution, v. 23, n. 3, p. 149-158, 2008. http://dx.doi.org/10.1016/j.tree.2007.11.005 
RAMBO, B. História da flora do litoral rio-grandense. Sellowia, n. 6, p. 113-172, 1954.

RAMBO, B. A flora de Cambará. Anais Botânicos do Herbário Barbosa Rodrigues, v. 1, n. 1, p. 111-135, 1949.

REITZ, P. R. Vegetação de Laguna (Santa Catarina). Sellowia, v. 6, n. 6, p. 243-258, 1954.

REITZ, R. (ed.). Vegetação da zona marítima de Santa Catarina. Anais Botânicos do Herbário Barbosa Rodrigues, n. 13, p. 17-115, 1961.

REITZ, R. Rosáceas. Itajaí: HBR, 1996. 135 p.

REITZ, R. Nictagináceas. Itajaí: HBR, 1970. 52 p.

ROCHA, C. F. D; VAN SLUYS, M; BERGALlO, H. G.; ALVES, M. A. S. Endemic and threatened tetrapods in the restingas of the biodiversity corridors of Serra do Mar and of the central da Mata Atlântica in Eastern. Brazilian Journal of Biology, v. 65, n. 1, p. 159-168, 2005. http://dx.doi.org/10.1590/S1519-69842005000100019

SACRAMENTO, A. C.; ZICKEL, C. S.; ALMEIDA JUNIOR, E. B. Aspectos florísticos da vegetação de restinga no litoral de Pernambuco. Revista Árvore, v. 31, n. 6, p. 11211130, 2007.

SAMPAIO, D.; SOUZA, V. C.; OLIVEIRA, A. A.; PAULA-SOUZA, J.; RODRIGUES, R. R. Árvores da Restinga: guia ilustrado para identificação das espécies da Ilha do Cardoso. São Paulo: Neotrópica, 2005.

SANTA CATARINA. Conselho Estadual de Meio Ambiente - CONSEMA. Resolução n. 51/2014. Lista oficial das espécies da flora ameaçada de extinção no estado de Santa Catarina. 2014. Acesso em: 10 maio 2016. Disponível em: https://goo.gl/uADUcv.

SANTOS, M.; FERMINO JUNIOR, P. C. P.; VAILATI, M. G.; PAUlilO, M. T. S. Aspectos estruturais de folhas de indivíduos de Guapira opposita (Vell) Reitz (Nyctaginaceae) ocorrentes em Restinga e na Floresta Ombrófila Densa. Insula, n. 39, p. 59-78, 2010. 10.5007/2178-4574.2010v39p59

SANTOS, R.; SILVA, R. C.; PACHECO, D.; MARTINS, R.; CITADINI-ZANETTE, V. Florística e estrutura do componente arbustivo-arbóreo de mata de restinga arenosa no Parque Estadual de Itapeva, Rio Grande do Sul. Revista Árvore, v. 36, n. 6, p. 1047 1059, 2012. http://dx.doi.org/10.1590/S0100-67622012000600006

SCARANO, F. R. Structure, function and floristic relantioships of plants communities in stressful habitats marginal to Brazilian Atlantic Rainforest. Annals of Botany, v. 90, p. 517-524, 2002.

SCARANO, F. R.; DUARTE, H. M.; RIBEIRO, K. T.; RODRIGUES, P. J. F. P.; BARCELLOS, E. M. B.; FRANCO, C. et al. Four sites with contrasting environmental stress in southeastern Brazil: relations of species, life form diversity, and geographical distribution to ecophysiological parameters. Botanical Journal of the Linnean Society, v. 136, p. 345-364, 2001. http://dx.doi.org/10.1111/j.1095-8339.2001. tb00579.x

SCHERER, A.; MARASCHIN-SILVA, F.; BAPTISTA, L. R. M. Florística e estrutura do componente arbóreo de matas de restinga arenosa no Parque Estadual de Itapuã, RS, Brasil. Acta botanica brasilica, v. 19, n. 4, p. 717-726, 2005. http://dx.doi.org/10.1590/S0102-33062005000400006 
SCHERER, A., MARASCHIN-SILVA, F.; BAPTISTA, L. R. M. Estrutura do componente arbóreo em remanescentes florestais nas Restingas sul brasileiras. Revista Brasileira de Biociências, v. 7, n. 4, p. 354-363, 2009.

SEVEGNANI, L.; COMTOIS, P. Olhares sobre a biodiversidade. In: SEVEGNANI, L.; SCHOEDER, E. Biodiversidade Catarinense: características, potencialidades e ameaças. Blumenau: Edifurb, 2013. p. 30-53.

SEVEGNANI, L.; VIBRANS, A. C.; GASPER, A. L. Considerações finais sobre a Floresta Ombrófila Densa e Restinga. In: VIBRANS, A. C.; SEVEGNANI, L.; GASPER, A. L.; LINGNER, D. V. (Ed.). Inventário florístico florestal de Santa Catarina: Floresta Ombrófila Densa. Blumenau: Edifurb, 2013. p. 325-327.

SILVA, S. M.; BRITEZ, R. M. A vegetação da Planície Costeira. In: MARQUES, M. C. M.; BRITEZ, R. M. (Org.). História natural e conservação da Ilha do Mel. Curitiba: Universidade Federal do Paraná, 2005. p.49-84.

SILVA, S. S. L.; ZICKEL, C. S.; CESTARO, L. A. Flora vascular e perfil fisionômico de uma restinga no litoral sul de Pernambuco, Brasil. Acta botanica brasilica, v. 22, n. 4, p. 1123-1135, 2008. http://dx.doi.org/10.1590/S0102-33062008000400023

SZTUTMAN, M.; RODRIGUES, R. R. O mosaico vegetacional numa área de floresta contínua da planície litorânea, Parque Estadual da Campina do Encantado, PariqueraAçu, SP. Revista Brasileira de Botânica, v. 25, n. 2, p. 61-176, 2002.

TABARELLI, M.; PERES, C. A. Abiotic and vertebrate seed dispersal in Brazilian Atlantic Forest: implications for forest regeneration. Biological Conservation, v. 106, n. 2, p. 165-176, 2002. http://dx.doi.org/10.1016/S0006-3207(01)00243-9

VAN der PIJL, L. Principles of dispersal in higher plants. 2. ed. Berlim: Springer-Verlag, 1972. 


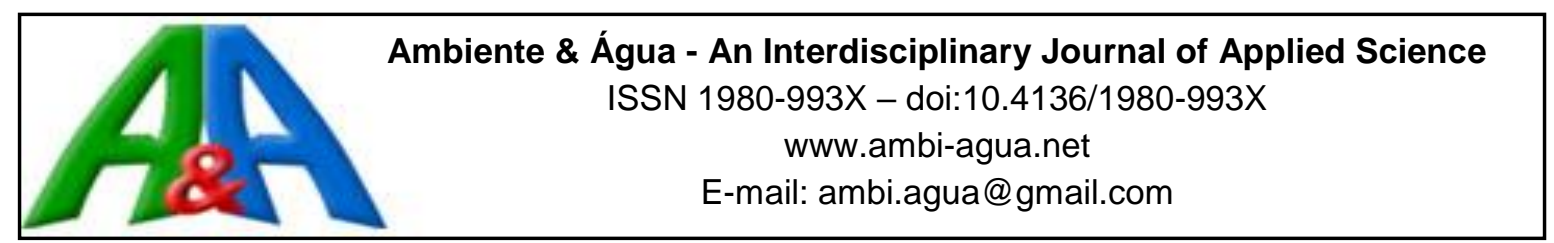

\title{
Composto de lodo de esgoto para o cultivo inicial de eucalipto
}

\author{
doi:10.4136/ambi-agua.1965
}

Received: 25 Jul. 2016; Accepted: 29 Oct. 2016

\author{
Daniela Cristina de Souza Afáz ${ }^{1}$; Kaique Bizon Bertolazi ${ }^{2}$; \\ Ricardo Augusto Gorne Viani ${ }^{2}$; Claudinei Fonseca Souza ${ }^{1 *}$ \\ Universidade Federal de São Carlos (UFSCar), Araras, SP. Brasil \\ ${ }^{1}$ Departamento de Recursos Naturais e Proteção Ambiental (DRNPA) \\ ${ }^{2}$ Departamento de Biotecnologia e Produção Vegetal e Animal (DBPVA) \\ *Autor correspondente: e-mail: cfsouza@cca.ufscar.br, \\ daniela.cr.souza@gmail.com,kbb7@hotmail.com,viani@cca.ufscar.br
}

\section{RESUMO}

Neste trabalho, foi avaliada a viabilidade do uso de composto de lodo de esgoto, proveniente de estação de tratamento de esgoto, como fertilizante alternativo para o cultivo inicial de eucalipto. O experimento foi realizado em casa de vegetação no CCA - UFSCar, Araras, SP. Os cultivos ocorreram em vasos de $11 \mathrm{~L}$ durante 75 dias. O delineamento experimental foi inteiramente ao acaso, com cinco tratamentos e sete repetições. Os tratamentos adotados foram constituídos por uma testemunha, três tratamentos com composto de lodo de esgoto $(25 \%, 50 \%$ e $75 \%$ do volume do vaso) e um tratamento com fertilizante mineral convencional, todos em solo arenoso. Ao final do experimento, a taxa de crescimento relativo (TCR) e a massa seca das plantas foram medidas e submetidas à análise de variância seguida pelo teste de Tukey a 5\% de probabilidade. A TCR foi maior nos tratamentos com fertilização do que na testemunha, mas não diferiu entre a fertilização mineral e as doses de fertilização orgânica. A massa seca das plantas foi maior no tratamento com $50 \%$ do volume do vaso com fertilizante orgânico $(\mathrm{p}<0,01)$. Assim, o composto de lodo de esgoto se mostrou com potencial para substituir fertilizantes minerais convencionais no cultivo inicial de eucalipto.

Palavras-chave: composto orgânico, fertilizante, nutrição vegetal,.orgânico classe D, sustentabilidade.

\section{Sewage sludge compost for initial cultivation of eucalyptus}

\begin{abstract}
This study evaluated the feasibility of sewage sludge compost obtained from a sewage treatment plant as an alternative "Class D" organic fertilizer for the initial cultivation eucalyptus. The experiment was conducted in a greenhouse at CCA - UFSCar, Araras, SP. Cultivation occurred in $11 \mathrm{~L}$ pots for 75 days. We adopted a completely randomized design, with five treatments and seven repetitions. The tests considered a control treatment with no fertilization, three treatments with sewage sludge compost addition $(25 \%, 50 \%$, and $75 \%$ of the pot volume) and a treatment with conventional mineral fertilizers, all in sandy soil. At the end of the experiment, plant relative growth rate and dry mass were evaluated and submitted to analysis of variance, followed by a Tukey test at 5\% probability. Treatments with
\end{abstract}


fertilization had a greater relative growth rate than the control; however, we found no difference between mineral and organic fertilization. Plant dry mass was higher in the treatment with $50 \%$ of the pot filled with organic fertilizer. Thus, we conclude that the tested sewage sludge compost is a potential substitute for conventional mineral fertilization for the initial cultivation of eucalyptus.

Keywords: class D organic fertilizer, organic compost, plant nutrition, sustainability.

\section{INTRODUÇÃO}

O lodo de esgoto é um resíduo rico em matéria orgânica, obtido ao final do processo de tratamento de águas servidas à população. A destinação adequada deste resíduo é necessária, devido aos problemas ambientais que podem ser ocasionados, principalmente com a contaminação do solo e da água. A deposição em aterros sanitários é uma destinação tida como segura, mas o alto custo da manutenção, que nem sempre é realizada adequadamente, pode não resolver problemas de contaminação do solo, ar e água (Quintana et al., 2011). Ou seja, há carência de formas seguras e eficazes de processamento e acondicionamento deste importante resíduo.

No Brasil, de acordo com o Sistema Nacional de Informações sobre Saneamento - SIS Diagnóstico de Serviço de Água e Esgoto 2014, o volume de esgoto tratado é de 3,8 bilhões de $\mathrm{m}^{3}$, correspondendo a 40,9\% da população que têm seu esgoto devidamente coletado e tratado. Este cenário é um desafio à destinação do resíduo orgânico, visto o grande volume gerado e o pequeno volume processado nos usos benéficos mais comuns ou de maior potencial: fabricação de cimento, disposição no solo, fabricação de tijolos e cerâmica e, também, aplicação para a melhoria da sedimentabilidade em águas de baixa turbidez, recuperação de coagulantes, controle de $\mathrm{H}_{2} \mathrm{~S}$, conversão em óleo combustível e recuperação de solos (Tsutiya, 2000; Rigo et al., 2014). Porém, ao mesmo tempo, esse cenário cria uma oportunidade a um dos potenciais destinos do lodo de esgoto, que é a agricultura. $\mathrm{Na}$ agricultura, há cada vez mais necessidade de se buscar fontes alternativas de fertilizantes que diminuam os custos de cultivos agrícolas e que tragam maiores opções aos produtores, adequando a exploração dos recursos naturais (Vaz e Gonçalves, 2002).

A aplicação de lodo de esgoto em cultivos agrícolas e também em áreas degradadas que precisam ser recuperadas tem sido o objeto de vários estudos (Caldeira Junior et al., 2009; Lobo et al., 2013; Bittencourt et al., 2014; Romeiro et al., 2014). De modo geral, os resultados têm sido positivos, destacando que o lodo fornece nutrientes e promove bom crescimento às plantas além de propiciar benefícios às propriedades físicas do solo (Rocha et al. 2004; Garcia et al., 2010; Bonini et al., 2015). O lodo é um condicionador do solo, que facilita a formação de agregados e, consequentemente, melhora a aeração, a infiltração e a retenção de água no solo, além de fornecer compostos orgânicos e nutrientes necessários para o desenvolvimento dos cultivos (Bonini e Alves, 2011).

Ao mesmo tempo em que o lodo de esgoto apresenta benefícios em seu uso agrícola, ele ocasiona riscos, pois o lodo pode apresentar quantidade elevada de metais pesados em sua composição, além de patógenos, vírus, protozoários e vermes, que podem contaminar o solo, o lençol freático e as plantas cultivadas (Soccol et al., 1997; Dores-Silva et al., 2011). Desse modo, sua aplicação direta na agricultura tem restrições.

Uma alternativa para a destinação do lodo de esgoto é a compostagem, que reduz os riscos e impactos ocasionados pela aplicação direta deste resíduo orgânico na agricultura. A compostagem é um processo biológico aeróbio de tratamento de resíduos orgânicos, que acelera a decomposição da matéria orgânica por micro-organismos e enzimas (Budziak et al., 2004). Durante o processo de compostagem, há elevação da temperatura e alterações na aeração, umidade, relação carbono:nitrogênio, teores de nutrientes e composição de 
micro-organismos da matéria prima. Estes fatores tendem a reduzir a presença de patógenos, parasitas e contaminantes no lodo de esgoto, tornando-o um produto mais seguro para uso na agricultura (Pereira et al., 2013).

Recentemente, fertilizantes passaram a ser produzidos comercialmente no Brasil a partir da compostagem do lodo de esgoto, gerando os compostos de lodo de esgoto, também chamados de fertilizantes orgânicos classe D. O fertilizante orgânico classe D é, de acordo com a Instrução Normativa $\mathrm{N}^{\mathrm{o}} 25$ de 23/07/2009 do Ministério da Agricultura, o fertilizante de origem orgânica que, em sua produção, utiliza-se de qualquer quantidade de matéria prima oriunda do tratamento de despejos sanitários, mas que resulta em produto de utilização segura na agricultura (Brasil, 2009), tendo empresas que comercializam e/ou distribuem estes compostos de lodo de esgoto.

Geralmente, estes compostos de lodo de esgoto têm como matéria prima não apenas o lodo de esgoto, mas resíduos diversos (restos de alimentos, resíduos de poda e corte de grama, etc.), adicionados durante o processo de compostagem. Mesmo sendo considerado seguro, há restrições de uso para o composto de lodo de esgoto: é proibido em pastagens, no cultivo de olerícolas, tubérculos e raízes, nas culturas inundadas e nas demais culturas cuja parte comestível entra em contato com o solo. Entretanto, este pode ser utilizado como fertilizante para espécies florestais destinadas à produção de madeira e celulose, por exemplo, tendo como potenciais vantagens a diminuição das descargas de lodo em aterros sanitários, incineradores, mares e corpos de água, a ciclagem dos nutrientes, o aporte de matéria orgânica no solo, e a possibilidade de redução de custos com o uso de fertilizantes minerais.

O eucalipto é amplamente cultivado no Brasil, ocupando mais de 5 milhões de ha e tendo um papel relevante para a economia do país (ABRAF, 2013). De modo geral, o eucalipto cresce rápido e responde a variações na fertilidade do solo (Mendes et al., 2013; Dias et al.; 2015). A adubação do eucalipto é realizada empregando-se geralmente fertilizantes minerais e, boa parte dos fertilizantes, é aplicada no momento do plantio (adubação de base), de modo a proporcionar o arranque das mudas no campo (Barros et al., 2000; Gonçalves, 2005). Portanto, há carência de estudos científicos com compostos de lodo de esgoto e, ao mesmo tempo, grande oferta deste produto e demanda de fertilizantes para a cultura do eucalipto. Desse modo, este estudo avaliou a viabilidade do uso de composto de lodo de esgoto (fertilizante orgânico classe D), proveniente de estação de tratamento, como fertilizante alternativo para a adubação na fase inicial do cultivo de eucalipto.

\section{MATERIAL E MÉTODOS}

O experimento foi conduzido em uma casa de vegetação do Departamento de Recursos Naturais e Proteção Ambiental (DRNPA) do CCA - UFSCar (Centro de Ciências Agrárias Universidade Federal de São Carlos), localizado em Araras, Estado de São Paulo, (22 $18 ' 22,4^{\prime \prime}$ S; $\left.47^{\circ} 23^{\prime} 11,1^{\prime \prime} \mathrm{O}\right)$. O clima da região é caracterizado por duas estações bem definidas, sendo uma seca, de abril a setembro, e outra chuvosa, de outubro a março, e enquadra-se no tipo "Cwa" de Köppen (Setzer, 1967), com uma precipitação média anual de $1300 \mathrm{~mm}$.

O estudo foi desenvolvido em casa de vegetação, composta por uma estrutura metálica do tipo teto em arco, com pé-direito de $3 \mathrm{~m}$, comprimento de $18 \mathrm{~m}$ e $6,4 \mathrm{~m}$ de largura, coberta com filme plástico transparente de 150 microns e com laterais fechadas por tela do tipo sombrite. O cultivo ocorreu de 12 de novembro de 2014 à 28 de janeiro de 2015, contabilizado 75 dias.

\subsection{Descrição do experimento}

O experimento foi composto por cinco tratamentos com sete repetições, totalizando 35 vasos, dispostos num delineamento inteiramente ao acaso (Figura 1). Os cinco tratamentos 
foram constituídos por: uma testemunha composta apenas por solo arenoso (T1), três tratamentos com 25\% (T2), 50\% (T3) e 75\% (T4) de composto de lodo de esgoto e um tratamento com adubação convencional (T5), todos em solo arenoso. As porcentagens foram fracionadas em $25 \%$ pela falta de fontes científicas para a recomendação da dosagem ideal para a cultura do eucalipto. Desta forma, também foi fonte de pesquisa a dosagem de melhor resposta.

O solo utilizado, pertencente ao grupo Neossolo Quartzarênico, foi coletado de uma camada superficial $(0-0,30 \mathrm{~m})$ na região de Leme, cujas coordenadas geográficas são: latitude $22^{\circ} 11^{\prime} 08^{\prime \prime}$ sul e longitude $47^{\circ} 23$ '25" oeste.

No experimento foi utilizado o composto de lodo de esgoto, proveniente da Estação de Tratamento de Esgoto - ETE Jundiaí (ETEJ), Jundiaí-SP, o qual utiliza o processo de lagoas aeradas de mistura completa, seguida de lagoa de decantação. O lodo de esgoto gerado pela ETEJ é compostado em sistema de Leiras Revolvidas (Sistema "Windrow"), a partir da sua mistura na proporção $1: 1 \mathrm{v} \mathrm{v}^{-1}$, com podas urbanas trituradas ou bagaço de cana-de-açúcar.

Mudas de eucalipto do hibrido urograndis (Eucalyptus urophylla $\mathrm{x}$ E. grandis), clone H13, foram obtidas no Instituto de Pesquisas e Estudos Florestais - IPEF, Piracicaba - SP. A escolha do eucalipto foi baseada na sua resposta rápida ao uso de fertilizantes, e também pelo fato de serem mudas clonadas, o que elimina a variabilidade genética como fonte de variação nos resultados.

As mudas foram transplantadas para vasos com dimensões de $0,24 \mathrm{~m}$ de diâmetro e 0,18 $\mathrm{m}$ de altura, com um volume de $11 \mathrm{~L}$. Para a preparação dos vasos, inicialmente foi acrescentado $1,5 \mathrm{~kg}$ de pedra tipo brita, em seguida um tecido geotêxtil (cuja finalidade foi de evitar a perda de solo pela drenagem) e, por fim, $8 \mathrm{~kg}$ de TFSA (terra fina seca ao ar) passada em peneira de $2 \mathrm{~mm}$, até atingir $2 \mathrm{~cm}$ da borda. Os vasos possuíam drenos na lateral inferior para retirar o excesso de água do solo.

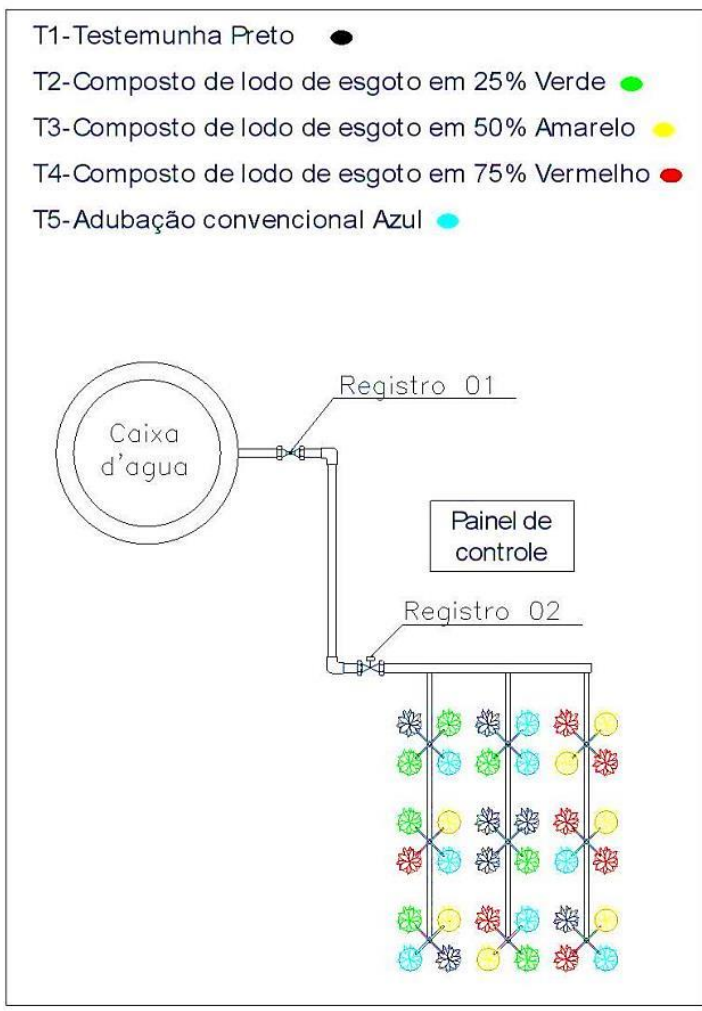

Figura 1. Distribuição ao acaso dos tratamentos avaliados dentro da casa de vegetação. 
No T5, foi realizada adubação com $36 \mathrm{~g}$ de N, $24 \mathrm{~g}$ de $\mathrm{P}_{2} \mathrm{O}_{5}$ e $30 \mathrm{~g}$ de $\mathrm{K}_{2} \mathrm{O}$ por vaso, que foram fornecidos através de $48 \mathrm{~g}$ de mono-amônio-fosfato $\left(50 \%\right.$ de $\mathrm{P}_{2} \mathrm{O}_{5}$ e $10 \%$ de $\mathrm{N}$ ), $68 \mathrm{~g}$ de nitrato de potássio $\left(44 \%\right.$ de $\mathrm{K}_{2} \mathrm{O}$ e $13 \%$ de $\left.\mathrm{N}\right)$ e $163 \mathrm{~g}$ de nitrato de cálcio $(15 \%$ de $\mathrm{N})$ por vaso. Esta adubação foi definida com base na análise do solo arenoso, seguindo as recomendações de fertilização do IPEF (Gonçalves, 2005). Porém, como essa recomendação é dada pela área, foi necessário dividir a quantidade de fertilizante demandado por hectare, pelo número de plantas existente num hectare, no espaçamento convencional de cultivo (1.667 plantas, espaçamento $3 \times 2 \mathrm{~m}$ ).

Os fertilizantes foram aplicados em cova no momento do transplantio, sendo a única adubação realizada no cultivo. O sistema de irrigação foi instalado com uma vazão de $1 \mathrm{~L} \mathrm{~h}^{-1}$ por vaso, o qual era acionado quatro vezes ao dia, com duração de 10 minutos por vez, aproximadamente com uma lamina de água de $3,7 \mathrm{~mm} \mathrm{dia}^{-1}$.

\subsection{Caracterização química do composto de lodo de esgoto}

A caracterização química (macro e micronutrientes, matéria orgânica e capacidade de troca catiônica - CTC) do composto de lodo de esgoto utilizado foi realizada no Laboratório de Química e Nutrição dos Solos do Centro de Ciências Agrárias, da UFSCar, seguindo os métodos estabelecidos para solos por Van Raij et al. (1997). Ressalta-se que estes métodos foram originalmente estabelecidos para solos, mas têm sido usados para a caracterização do lodo, em virtude da ausência de métodos de análise mais específicos para este tipo de material.

Foram coletadas cinco amostras de $10 \mathrm{~g}$ de composto de lodo de esgoto, as quais compuseram uma única amostra composta.

\subsection{Análise de micro-organismos patogênicos}

Foram feitas análises iniciais no composto para verificar a presença de micro-organismos patogênicos, por meio da coleta de duas amostras de $10 \mathrm{~g}$, encaminhadas para o Laboratório de Microbiologia Aplicada da UFSCar. Foram avaliadas a presença dos micro-organismos coliformes totais e termotolerantes (Escherichia coli), as quais são usadas como indicadoras de contaminação por fezes humanas, sendo E. coli uma bactéria presente no trato intestinal de animais de sangue quente.

Foi adotada a metodologia das placas Petrifilm da $3 \mathrm{M}^{1}$ para coliformes totais e E. coli. As amostras para a análise microbiológica foram manipuladas em câmara de fluxo laminar em solução de peptona $0,1 \%$, sendo posteriormente inoculadas nas placas Petrifilm. Após o período de incubação de 24 e $48 \mathrm{~h}$, procedeu-se a contagem de coliformes totais e $E$. coli, respectivamente.

\subsection{Análises do crescimento do eucalipto}

Para alcançar o objetivo de avaliar o crescimento das plantas ao longo do tempo experimental, avaliou-se, ao final do experimento, a matéria seca das plantas. Além disso, foi mensurada a taxa de crescimento relativo (TCR), usando a Equação 1 (Benincasa, 2003).

$$
\operatorname{TCR}\left(\frac{g / g}{\text { dias }}\right)=\frac{(\ln \mathrm{M} 2-\ln \mathrm{M} 1)}{(\mathrm{P} 2-\mathrm{P} 1)}
$$

em que:

M1 - massa seca total inicial;

M2 - massa seca total final;

\footnotetext{
${ }^{1}$ Referências à marca registrada não constituem endosso por parte dos autores.
} 
$(\mathrm{P} 2-\mathrm{P} 1)$ - intervalo em dias do início ao final do experimento.

Para as medidas de TCR, foram avaliadas, no início do experimento, no momento do plantio, 10 mudas de eucalipto não utilizadas. Para a análise da matéria seca, as plantas foram secas em estufa de circulação de ar a $60^{\circ} \mathrm{C}$ durante $48 \mathrm{~h}$.

\subsection{Análise estatística dos dados}

Os dados de massa seca e TCR das plantas foram submetidos à análise de variância utilizando o programa Assistat 7.6 Beta (Silva e Azevedo, 2009). Quando a ANOVA foi significativa, as médias dos tratamentos foram comparadas entre si usando o teste de Tukey $(\mathrm{p}<0,05)$.

\section{RESULTADOS E DISCUSSÃO}

\subsection{Caracterização química e microbiológica}

O composto de lodo de esgoto avaliado apresentou $49 \%$ de matéria orgânica e uma alta CTC (Tabela 1). Os compostos nutricionais com maiores teores em sua composição foram óxido de cálcio e sulfato, seguidos pelo pentóxido de fósforo. Moretti et al. (2015) encontraram valores de grandeza semelhantes para composto de lodo de esgoto, na ordem de 18,12 e $3 \mathrm{~g} \mathrm{~kg}^{-1}$ para NPK e 21, 3 e $5 \mathrm{~g} \mathrm{~kg}^{-1}$ para Ca, Mg e S. Entretanto, os resultados são discrepantes para $\mathrm{K}$ e $\mathrm{S}$, os quais podem ser explicados devido à sazonalidade na composição física, química e biológica do esgoto bruto.

\begin{tabular}{lc}
$\begin{array}{l}\text { Tabela 1. Caracterização } \\
\text { microbiológica do composto de lodo de esgoto }\end{array}$ \\
$\begin{array}{l}\text { utilizado em experimento com cultivo de } \\
\text { eucalipto. }\end{array}$ \\
\hline \multicolumn{1}{c}{ Parâmetros } & Valor \\
\hline $\mathrm{pH}$ & 7,4 \\
Matéria orgânica $\left(\mathrm{g} \mathrm{kg}^{-1}\right)$ & 490 \\
Carbono $\left(\mathrm{g} \mathrm{kg}^{-1}\right)$ & 282 \\
Nitrogênio $\left(\mathrm{g} \mathrm{kg}^{-1}\right)$ & 17 \\
Pentóxido de fósforo $\left(\mathrm{g} \mathrm{kg}^{-1}\right)$ & 25,4 \\
Oxido de potássio $\left(\mathrm{g} \mathrm{kg}^{-1}\right)$ & 15 \\
Óxido de cálcio $\left(\mathrm{g} \mathrm{kg}^{-1}\right)$ & 26,2 \\
Óxido de magnésio $\left(\mathrm{g} \mathrm{kg}^{-1}\right)$ & 5,2 \\
Sulfato $\left(\mathrm{g} \mathrm{kg}^{-1}\right)$ & 26,2 \\
Cobre $\left(\mathrm{g} \mathrm{kg}^{-1}\right)$ & 0,6 \\
Ferro $\left(\mathrm{g} \mathrm{kg}^{-1}\right)$ & 2,3 \\
Manganês $\left(\mathrm{g} \mathrm{kg}^{-1}\right)$ & 0,5 \\
Zinco $\left(\mathrm{g} \mathrm{kg}^{-1}\right)$ & 1,3 \\
CTC $\left(\mathrm{mmolc} \mathrm{kg}^{-1}\right)$ & 240 \\
Coliformes totais & $>10^{-3}$ \\
Coliformes termotolerantes & Ausentes \\
\hline
\end{tabular}

Os coliformes termotolerantes (Escherichia coli) foram ausentes no fertilizante orgânico e, para coliformes totais $>10^{3} \mathrm{UFC} / \mathrm{g}$ (Tabela 1). Portanto, de acordo com as análises, o processo de compostagem provavelmente permitiu a inativação de coliformes termotolerantes presentes no lodo. O mesmo resultado pode ser observado por Rocha et al. (2013), que não 
encontraram coliformes termotolerantes quando avaliaram composto de lodo de esgoto como componente de substrato para produção de mudas clonais de eucalipto.

\subsection{Taxa de crescimento relativo e massa seca}

A TCR não diferiu quando comparados os tratamentos com o composto de lodo de esgoto e o fertilizante convencional, porém a testemunha sem fertilização apresentou uma menor TCR (Tabela 2, Figura 2). Estes resultados indicam que as taxas de crescimento do eucalipto não foram diferentes em função da fonte orgânica ou mineral dos fertilizantes, sugerindo que o composto de lodo de esgoto testado poderia substituir o fertilizante mineral convencional. Ademais, corroboram os resultados de Vaz e Gonçalves (2002), que também observaram uma igualdade no desenvolvimento de plantas de eucalipto fertilizadas com biossólido e fertilizantes minerais.

Tabela 2. Análise de variância da taxa de crescimento relativo ao final do período em casa de vegetação das plantas de eucalipto de cada tratamento (g $\left.\mathrm{g}^{-1} \mathrm{p}\right)$.

\begin{tabular}{lcccc}
\hline Causas de Variação & GL & SQ & QM & F \\
\hline Tratamentos & 4 & 3,16 & 0,79 & $16,11^{* *}$ \\
Resíduo & 30 & 1,47 & 0,05 & \\
\hline Total & $\mathbf{3 4}$ & $\mathbf{4 , 6 3}$ & & \\
\hline
\end{tabular}

** significativo ao nível de $1 \%$ de probabilidade ( $>>0,01)$; ns: não significativo ( $\mathrm{p} \geq 0,05)$; GL: grau liberdade; $\mathbf{S Q}$ : soma de quadrados; $\mathbf{Q M}$ : quadrado médio; e $\mathbf{F}$ : estatística do teste F.

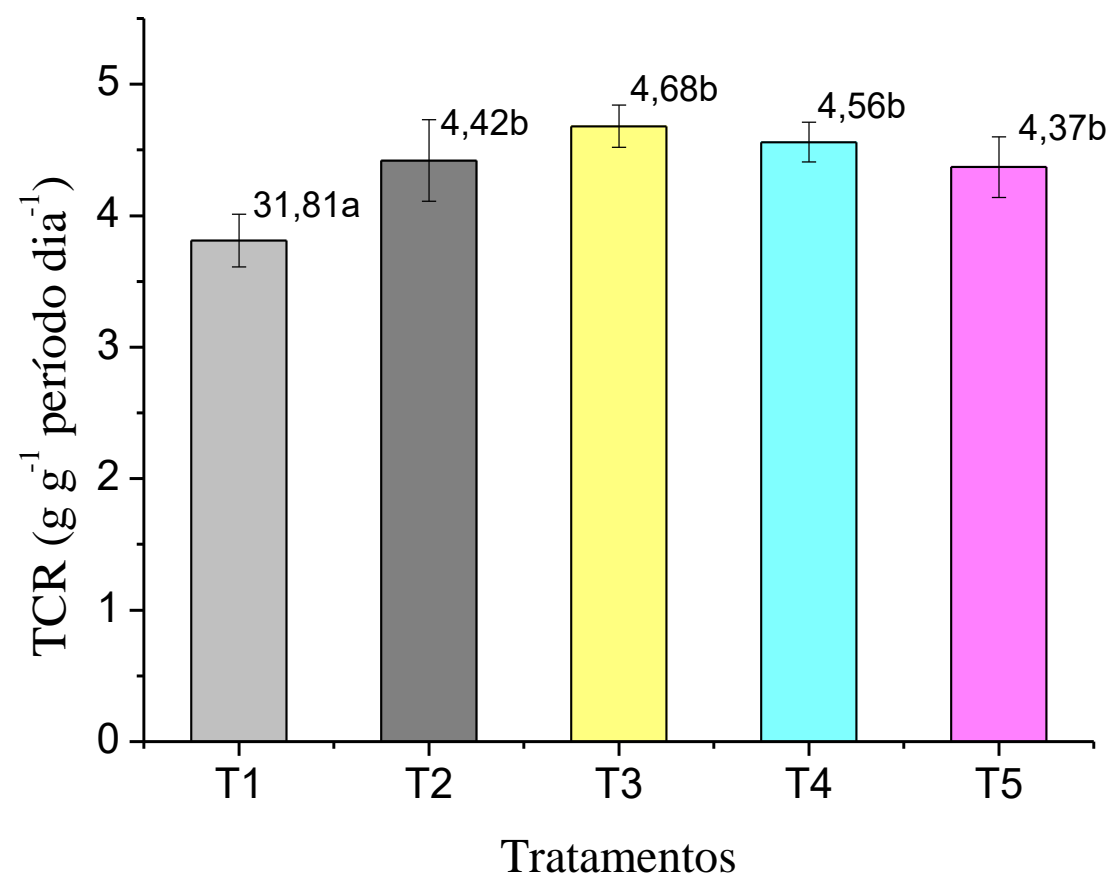

Figura 2. Resultados médios da Taxa de Crescimento Relativo ( $\mathrm{g} \mathrm{g}^{-1}$ período) após 75 dias de cultivo em casa de vegetação, para mudas de eucalipto submetidas a diferentes doses de composto de lodo de esgoto. Barras com letras diferentes diferem entre si (teste de Tukey, $\mathrm{p}<0,05)$. T1: testemunha em solo arenoso, T2: $25 \%$ de fertilizante orgânico; T3: 50\% de fertilizante orgânico; T4: $75 \%$ de fertilizante orgânico; T5: adubação mineral convencional. 
No entanto, os tratamentos diferiram entre si em relação ao acúmulo de massa seca (Tabela 3). Plantas do T3 (50\% de fertilizante orgânico) acumularam mais massa seca que plantas dos demais tratamentos com fertilização, os quais foram superiores à testemunha (Figura 3). Estes resultados corroboram parcialmente com os observados por Garcia et al. (2010), que também verificaram um incremento da massa seca e da TCR de eucalipto cultivado em ambiente protegido, Porém, diferentemente deste estudo, os resultados observados por Garcia et al. (2010) foram com aplicação de lodo de esgoto e com as maiores doses do fertilizante orgânico, proporcionando os maiores valores de TCR e massa seca no eucalipto.

Tabela 3. Análise de variância da matéria seca total das plantas de eucalipto de cada tratamento ( $\mathrm{g}$ planta ${ }^{-1}$ ) ao final do período em casa de vegetação.

\begin{tabular}{lcccc}
\hline Causas de Variação & GL & SQ & QM & F \\
\hline Tratamentos & 4 & 16745,21 & 4186,3 & $12,72 * *$ \\
\hline Resíduo & 30 & 9869,04 & 328,96 & \\
\hline Total & 34 & 26614,25 \\
** significativo ao nível de 1\% de probabilidade (p>0,01); ns: não significativo \\
(p $\geq 0$,05); GL: grau liberdade; SQ: soma de quadrados; QM: quadrado médio; \\
F: estatística do teste F.
\end{tabular}

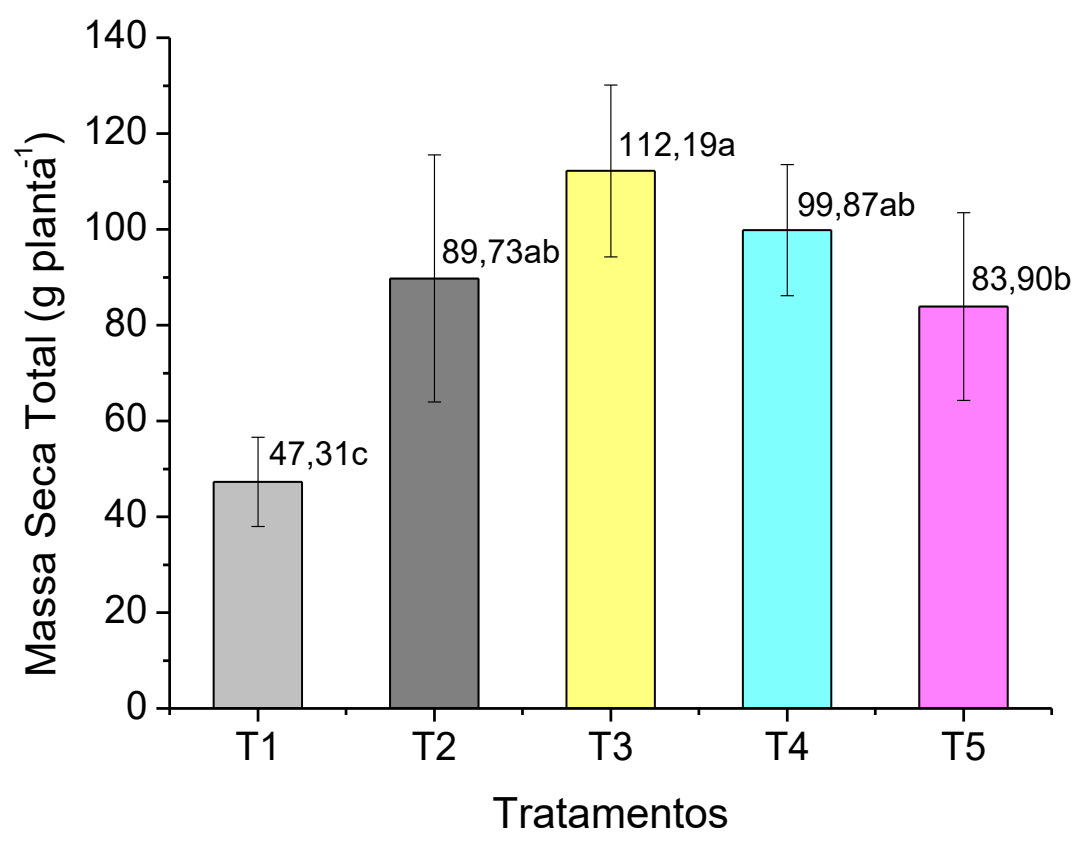

Figura 3. Resultados médios da Massa Seca Total $\left(\mathrm{g}\right.$ planta $\left.{ }^{-1}\right)$ após 75 dias de cultivo em casa de vegetação, para mudas de eucalipto submetidas a diferentes doses de composto de lodo de esgoto. Barras com letras diferentes diferem entre si (teste de Tukey, $\mathrm{p}<0,05)$. T1: testemunha em solo arenoso, T2: $25 \%$ de fertilizante orgânico; T3: 50\% de fertilizante orgânico; T4: 75\% de fertilizante orgânico; T5: adubação mineral convencional.

O incremento na massa seca com a fertilização orgânica se deve a um aumento de nutrientes no solo seguido de um efeito de melhoria da estrutura que a matéria orgânica 
promove (Costa et al., 2001). Esse efeito causa um aumento na CTC do solo, em função das cargas negativas da matéria orgânica, ampliando o "reservatório nutricional" do solo. Outro benefício é o aumento da taxa de microporosidade do solo, aumentando a retenção de água no mesmo. Além disso, a matéria orgânica introduz no sistema micronutrientes que geralmente não são fornecidos através da fertilização mineral concentrada em NPK. Rocha et al. (2004), pesquisando as alterações de fertilidade no solo e desenvolvimento de um povoamento de Eucalyptus grandis adubado com biossólido, verificaram que os tratamentos com fertilizante orgânico foram superiores ao tratamento com fertilizantes minerais, assim obtendo resultados ainda mais evidentes dos incrementos no desenvolvimento das plantas adubadas com fertilizantes orgânicos.

Diante destas constatações, era esperado que o tratamento $\mathrm{T} 4$ (75\% de fertilizante orgânico), com maiores doses do fertilizante orgânico, proporcionasse o maior acúmulo de massa seca nas plantas de eucalipto. Entretanto, foi encontrada maior massa seca com um tratamento intermediário quanto à adição de matéria orgânica. Investigações futuras são necessárias para compreender quais alterações ocasionaram um decréscimo na massa seca quando doses maiores do composto de lodo de esgoto foram adicionadas, algo não observado com eucalipto em outros experimentos realizados com o lodo aplicado in natura (Rocha et al. 2004; Garcia et al., 2010).

\section{CONCLUSÃO}

Com os resultados deste trabalho é possível concluir que, nas condições experimentais, a aplicação de composto de lodo de esgoto promoveu desenvolvimento inicial satisfatório das plantas de eucalipto, não havendo prejuízo em termos de acúmulo de matéria seca, taxa de crescimento ou acúmulo de nutrientes nas folhas.

A TCR não apresentou diferença significativa nos cultivos com composto de lodo de esgoto e convencional (adubação mineral), revelando que o uso do composto de lodo de esgoto ou convencional proporcionam desenvolvimento inicial semelhante das plantas de eucalipto. Já a matéria seca das plantas foi maior com a adição de $50 \%$ de fertilizante orgânico no solo de cultivo do que com a fertilização mineral. Portanto, o composto de lodo de esgoto poderia ser utilizado em substituição ao fertilizante mineral, no cultivo do eucalipto.

\section{AGRADECIMENTOS}

Ao CCA/UFSCar, PPGAA, CAPES, EASA, Tera Ambiental e IPEF.

\section{REFERÊNCIAS}

ASSOCIAÇÃO BRASILEIRA DE PRODUTORES DE FLORESTAS PLANTADAS ABRAF. Anuário Estatístico da ABRAF 2013: ano base 2012. Brasília, 2013. 146p.

BARROS, N. F.; NEVES, J. C. L.; NOVAIS, R. F. Recomendação de fertilizantes minerais em plantios de eucalipto. In: GONÇALVES, J. L. de M.; BENEDETTI, V. (Eds.). Nutrição e fertilização florestal. Piracicaba: IPEF, 2000. p. 269-286.

BENINCASA, M. M. P. Análise de crescimento de plantas: (noções básicas. Jaboticabal: FUNEP, 2003. 42p. 
BITTENCOURT, S.; SERRAT, B. M.; AISSE, M. M.; GOMES, D. Sewage Sludge Usage in agriculture: a case study of its destination in the Curitiba metropolitan region, Paraná, Brazil. Water, Air \& Soil Pollution, v. 225, p. 1-8, 2014. http://dx.doi.org/10.1007/s11270-014-2074-y

BONINI, C. S. B; ALVES, M. C.; MONTANARI, R. Lodo de esgoto e adubação mineral na recuperação de atributos químicos de solo degradado. Revista Brasileira de Engenharia Agrícola e Ambiental, v. 19, n. 4, p.388-393, 2015. http://dx.doi.org/10.1590/1807-1929/agriambi.v19n4p388-393

BONINI, C. S. B.; ALVES, M. C. Estabilidade de agregados de um Latossolo vermelho degradado em recuperação com adubos verdes, calcário e gesso. Revista Brasileira de Ciência do Solo, v. 35, n. 4, p. 1263-1270, 2011. http://dx.doi.org/10.1590/S010006832011000400019

BRASIL. Ministério da Agricultura e Abastecimento - MAPA. Instrução Normativa $\mathrm{n}^{\circ}$ 25, de 23 de julho de 2009. Aprova as Normas sobre as especificações e as garantias, as tolerâncias, o registro, a embalagem e a rotulagem dos fertilizantes orgânicos simples, mistos, compostos, organominerais e biofertilizantes destinados à agricultura. Diário Oficial [da] União, Brasília, DF, 28 de julho de 2009. Seção 1, p. 20.

BUDZIAK, C. R.; MAIA, C. M. B. F.; MANGRICH, A. S. Transformações químicas da matéria orgânica durante a compostagem de resíduos da indústria madeireira. Química Nova, v. 27, v. 3, p. 399-403, 2004. http://dx.doi.org/10.1590/S010040422004000300007

CALDEIRA JUNIOR, C. F.; SOUZA, R. A.; SANTOS, A. M.; SAMPAIO, R. A.; MARTINS, E. R. Características químicas do solo e crescimento de Astronium fraxinifolium Schott em área degradada adubada com lodo de esgoto e silicato de cálcio. Revista Ceres, v. 56, p. 213-218, 2009.

COSTA, A. N.; COSTA, A. F. S.; MARQUES, M. O.; SANTANA, R. C. Estudo de caso utilização de lodo de estações de tratamento de esgoto (ETEs) na cultura do mamoeiro no Norte do Estado do Espírito Santo. In: ANDREOLI, V. (Coord.). Resíduos sólidos do saneamento: processamento, reciclagem e disposição final. Rio de Janeiro: RiMa/ABES, 2001. p. 189-214.

DIAS, L. P. R.; GATIBONI, L. C.; BRUNETTO, G.; SIMONETE, M. A.; BICARATTO, B. Eficiência relativa de fosfatos naturais na adubação de plantio de mudas de Eucalyptus dunnii Maiden e Eucalyptus benthamii Maiden et Cambage em solo sem e com calagem. Ciência Florestal, v. 25, n. 1, p. 37-48, 2015. http://dx.doi.org/10. 5902/1980509817443

DORES-SILVA, P. R.; LANDGRAF, M. D.; REZENDE, M. O. Acompanhamento químico da vermicompostagem de lodo de esgoto doméstico. Química Nova, v. 34, n. 6, p. 956981, 2011. http://dx.doi.org/10.1590/S0100-40422011000600008

GARCIA, G. O.; GONÇALVES, I. Z.; MADALÃO, J. C.; NAZÁRIO, A. A.; REIS, E. F. Crescimento de mudas de eucalipto submetidas à aplicação de biossólidos. Ciência Agronômica, v. 41, n. 1, p. 87-94, 2010.

GONÇALVES, J. L. M. Recomendações de adubação para eucalyptus, pinus e espécies nativas. 2005. Disponível em: http://www.ipef.br/silvicultura/adubacao.asp. Acesso em: jul. 2016. 
LOBO, T. F., GRASSI FILHO, H.; BULL, L. T.; KUMMER, A. C. B. Efeito do lodo de esgoto e do nitrogênio nos fatores produtivos do girassol. Revista Brasileira de Engenharia Agrícola e Ambiental, v. 17, p. 504-509, 2013. http://dx.doi.org/ 10.1590/S1415-43662013000500006

MENDES, H. S. J.; PAULA, N. F.; SCARPINATTI, E. A.; PAUlA, R. C. Respostas fisiológicas de genótipos de Eucalyptus grandis x E. urophylla à disponibilidade hídrica e adubação potássica. Cerne, v. 19, n. 4, p. 603-611, 2013. http://dx.doi.org/10.1590/S0104-77602013000400010

MORETTI, S. M. L.; BERTONCINI, E. I.; ABREU-JUNIOR, C. H. Composting sewage sludge with green waste from tree pruning. Scientia Agricola, v. 72, p. 432-439, 2015. http://dx.doi.org/10.1590/0103-9016-2014-0341

PEREIRA, D. C.; WILSEN NETO, A.; NÓBREGA, L. H. Adubação orgânica e algumas aplicações agrícolas. Varia Scientia Agrárias, v. 3, n. 2, p. 159-174, 2013.

QUINTANA, N. R. G.; CARMO, M. S., MELO, W. J. Lodo de esgoto como fertilizante: produtividade agrícola e rentabilidade econômica. Nucleus, v. 8, n. 1, p. 183-912, 2011 http://dx.doi.org/10.3738/nucleus.v8i1.527

RIGO, M. M.; RAMOS, R. R.; CERQUEIRA, A. A.; SOUZA, P. S. A.; MARQUES, M. R. C. Destinação e reuso na agricultura do lodo de esgoto derivado do tratamento de águas residuária domésticas no Brasil. Gaia Scientia, v. 8, n. 1, p. 174-186, 2014.

ROCHA, G. N.; GONÇALVES, J. L. M.; MOURA, I. M. Mudanças da fertilidade do solo e crescimento de um povoamento de Eucalyptus grandis fertilizado com biossólido. Revista Brasileira de Ciência do Solo, v. 28, n. 4, p. 623-639, 2004. http://dx.doi.org/10.1590/S0100-06832004000400005

ROCHA, J. H. T.; BACKES, C.; DIOGO, F. A.; PASCOTTO, C. B.; BORELLI, K. Composto de lodo de esgoto como substrato para mudas de eucalipto. Pesquisa Florestal Brasileira, v. 33, n. 73, p. 27-35, 2013.

ROMEIRO, J. C. T.; GRASSI FILHO, H.; MOREIRA, L. L. Q. Absorção de N, P, K, CA e $\mathrm{Mg}$ por laranjeiras 'pêra' fertilizadas com lodo de esgoto compostado em substituição à adubação nitrogenada mineral. Irriga, v. 19, n. 1, p. 82-93, 2014.

SETZER, J. Atlas climático e ecológico do Estado de São Paulo. São Paulo: Comissão interestadual da Bacia Paraná-Uruguai, 1967.

SILVA, F. A. S.; AZEVEDO, C. A. V. Principal components analysis in the software assistant-statistical. In: WORLD CONGRESS ON COMPUTERS IN AGRICULTURE, 7., 2009, Reno. Proceedings... St. Joseph: ASABE, 2009.

SOCCOL, V. T.; PAULINO, R. C.; CASTRO, E. A.; TRACZ, J. Eficácia dos diferentes processos de tratamento do lodo na redução da viabilidade de ovos de helmintos. Sanare, v. 8, n. 8, p. 24-32, 1997.

TSUTIYA, M. T. Alternativas de disposição final de biossólidos gerados em estações de tratamento de esgotos. In: BETTIOL, W.; CAMARGO, O. A. (Eds.). Impacto ambiental do uso agrícola do lodo de esgoto. Jaguariúna: EMBRAPA Meio Ambiente, 2000. p. 69-105. 
Van RAIJ, B.; CANTARElla, J. A.; QUAGGiO, J. A.; FURLANI, A. M. C. Recomendações de adubação e calagem para o Estado de São Paulo. Campinas: Instituto Agronômico, 1997. 285p. (Boletim técnico, 10).

VAZ, L. M. S; GONÇALVES, J. L. M. Uso de biossólidos em povoamento de eucalipto: efeito em atributos químicos do solo, no crescimento e na absorção de nutrientes. Revista Brasileira de Ciência do Solo, v. 26, n. 3, p. 747-758, 2002. http://dx.doi.org/10.1590/S0100-06832002000300020 


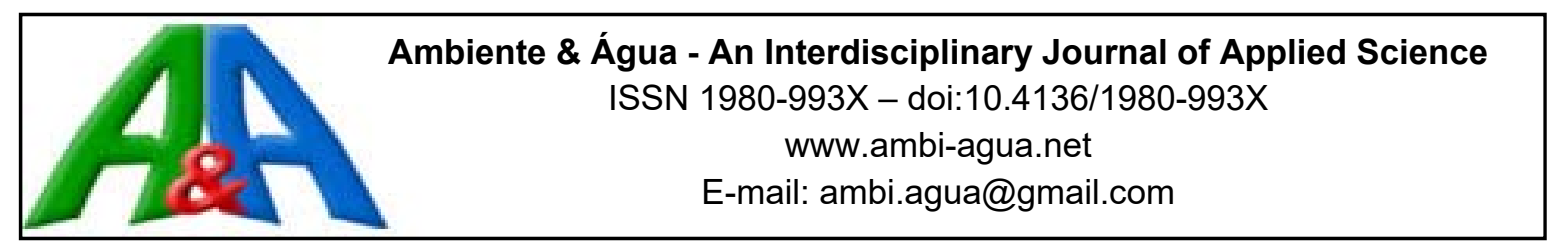

\title{
Aspectos socioambientais e qualidade da água de dessalinizadores nas comunidades rurais de Pentecoste-CE
}

\author{
doi.org/10.4136/ambi-agua.1722 \\ Received: 06 Aug. 2015; Accepted: 05 Nov. 2016 \\ Antônia Leila Rocha Neves ${ }^{1 *}$; Mailson Pereira Alves ${ }^{1}$; \\ Claudivan Feitosa de Lacerda ${ }^{1}$; Hans Raj Gheyi ${ }^{2}$ \\ ${ }^{1}$ Universidade Federal do Ceará (UFC), Fortaleza, CE, Brasil \\ Departamento de Engenharia Agrícola \\ ${ }^{2}$ Universidade Federal do Recôncavo da Bahia (UFRB), Cruz das Almas, BA, Brasil \\ Núcleo de Engenharia de Água e Solo/CCAAB \\ *Autor correspondente: e-mail: leilaneves7@hotmail.com, \\ mailsonpa@gmail.com, cfeitosa@ufc.br, hans@pq.cnpq.br
}

\section{RESUMO}

Os dessalinizadores de água salobra de poços são bastante utilizados para dotar as comunidades rurais do semiárido brasileiro com água potável, sendo considerada uma tecnologia social de convivência com a seca. No entanto, na dessalinização, além da água potável, é gerada uma água residuária (rejeito) altamente salina que pode gerar sérios impactos ambientais negativos. Objetivou-se avaliar a qualidade da água e a percepção dos usuários quanto aos aspectos socioambientais relacionados à utilização de equipamentos de dessalinização instalados em oito localidades em Pentecoste, Ceará (Mulungu, Muquenzinho, Irapuá, Macacos, Barra do Leme, Capivara, Lagoa da Porta e Providência). Em cada localidade, foram coletadas três amostras de água do poço, dessalinizada e de rejeito, para caracterização físico-química. Os valores de CE para o rejeito variaram de 4,2 a 7,6 dS m m $^{-1}$, representando riscos para o ambiente de acordo com padrões estabelecidos mundialmente. A localidade de Muquenzinho apresenta os maiores valores de $\mathrm{pH}, \mathrm{CE}, \mathrm{Na}$ e Ca para água do poço, dessalinizada e rejeito, em relação às demais localidades. A maior parte do rejeito gerado é utilizada para alimentação animal e a grande maioria da população, independente da localidade, não tem conhecimento se o uso desse rejeito causa algum dano à saúde humana ou ao ambiente.

Palavras-chave: água subterrânea, rejeito de dessalinizador, salinidade, Semiárido.

\section{Socio-environmental aspects and quality of water from desalination plants in rural communities of Pentecoste-CE}

\section{ABSTRACT}

Desalination plants are of great interest as an alternative to supply drinking water to hundreds of locations in the Brazilian semi-arid region and it is a social technology to cope with drought. However, desalination waste can contaminate groundwater and cause serious environmental impacts. The objective of this work was, therefore, to evaluate the quality of water and the perception of users regarding the socio-environmental aspects of the use of 
desalination equipment installed at eight locations in the municipality of Pentecoste, Ceará. The towns of Mulungu, Muquenzinho, Irapuá, Macacos, Barra do Leme, Capivara, Lagoa da Porta, and Providência were visited. In each location, three samples were taken of desalinated well water, and desalination wastes were collected in plastic bottles, and their chemical composition was analyzed. The values of $\mathrm{ECw}$ of the waste ranged from 4.2 to $7.6 \mathrm{dS} \mathrm{m}^{-1}$, representing risks to the environment per established standards worldwide. The locality of Muquenzinho has the highest values of $\mathrm{pH}, \mathrm{ECw}, \mathrm{Na}$ and $\mathrm{Ca}$ at different water sources. Most of the desalination waste generated is used for animal feed and the vast majority of the population, regardless of location, is not aware whether the use of waste water may be harmful to human health or to the environment.

Keywords: desalinization wastes, groundwater, salinity, Semi-arid.

\section{INTRODUÇÃO}

Devido à escassez de águas superficiais, o uso de águas subterrâneas tem aumentado muito em todo mundo. Estimativas apontam que 300 milhões de poços foram perfurados no mundo nas três últimas décadas. Praticamente todos os países do mundo, desenvolvidos ou não, utilizam água subterrânea para suprir suas necessidades. A Europa, por exemplo, tem $75 \%$ de sua população atendida com água do subsolo, percentual passível de atingir $90 \% \mathrm{em}$ países como Suécia, Holanda e Bélgica (Medeiros et al., 2011; Oster et al., 2012). No Brasil, estima-se que pelo menos metade do abastecimento de água potável seja fornecido por recursos hídricos subterrâneos (Silva et al., 2007).

Embora as águas subterrâneas sejam uma alternativa viável para garantir o acesso das comunidades rurais do nordeste à água, essas fontes hídricas apresentam, na maioria dos casos, restrições de uso para dessedentamento humano por apresentarem problemas de salinidade (Ayers e Westcot, 1999).

Nas comunidades rurais do Nordeste brasileiro, a utilização de águas subterrâneas de poços tubulares é uma alternativa ao abastecimento d'água. No entanto, há uma grande limitação na utilização desses poços para enfrentamento da escassez hídrica, que é o elevado teor de sais dissolvidos (Silva et al., 2007; Fernandes et al., 2010; Santos et al., 2011).

Para solucionar este problema, há cerca de seis anos o 'Programa Água Boa' do Governo Federal instalou, em várias comunidades rurais do Nordeste, estações de tratamentos de água por osmose reversa a fim de obter água potável para as famílias por meio da dessalinização da água salobra de poços.

Entretanto, no processo de dessalinização se gera, além da água potável, um rejeito altamente salino e de poder poluente elevado. No semiárido brasileiro, mais de 3 mil dessalinizadores de osmose reversa estão em funcionamento, com a função de transformar a água salobra de poços e açudes em água potável. Segundo a Superintendência de Obras Hidráulicas (SOHIDRA), foram construídos cerca de 4.500 poços em comunidades de todo o Ceará, em seus 184 municípios. Ao todo, a SOHIDRA já instalou um total de 450 dessalinizadores em 87 municípios (Ceará, 2011; 2012).

A produção do rejeito proveniente da dessalinização da água pode contaminar o lençol freático e gerar sérios impactos ambientais no solo. Dependendo do equipamento e da qualidade da água do poço, a quantidade de rejeito gerado é da ordem de 40 a $70 \%$ do total de água salobra retirada (Beltrán e Koo-Oshima, 2006; Porto et al., 2006; Wanderley, 2009). Destaca-se, portanto, a necessidade de aproveitamento do rejeito com atividades da agricultura como piscicultura e/ou mineração evitando-se, assim, impactos ambientais negativos (Soares et al., 2006; Ceará, 2008; Wanderley, 2009). 
Diante do exposto, objetivou-se neste estudo avaliar a qualidade da água de dessalinizadores em oito localidades no município de Pentecoste, Ceará, e a percepção dos usuários quanto aos aspectos socioambientais relacionados à utilização de equipamentos de dessalinização instalados.

\section{MATERIAL E MÉTODOS}

O estudo foi realizado nos meses de novembro e dezembro de 2009, em oito comunidades localizadas no município de Pentecoste ( $3^{\circ} 47^{\prime} \mathrm{S} ; 39^{\circ} 16^{\prime} \mathrm{W}$, e altitude de $45 \mathrm{~m}$ ), Ceará, (Mulungu, Muquenzinho, Irapuá, Macacos, Barra do Leme, Capivara, Lagoa da Porta e Providência). Pentecoste fica localizada na Bacia Hidrográfica do Rio Curu e conta com o açude Pereira de Miranda, que abastece a sede do município. O município possui população, estimada no ano de 2010, de 35.400 habitantes (IBGE, 2012), com uma área territorial de $1.378 \mathrm{~km}^{2}$, sendo que parte das comunidades não dispõe de fontes de abastecimento de água durante o ano todo.

$\mathrm{O}$ aspecto geral das localidades estudadas é semelhante em muitas características, tais como: se encontram na mesma região de clima semiárido, possuem vegetação caatinga, a população fica acomodada apenas numa pequena área central, a presença de estabelecimentos comerciais, escola e casas.

Realizou-se uma pesquisa qualitativa junto às famílias beneficiadas por dessalinizadores, e também nas localidades onde o dessalinizador não estava em funcionamento, utilizando a técnica de entrevista com aplicação de questionários; a duração das entrevistas foi, em média, de $20 \mathrm{~min}$, pois o fato de o questionário estar composto de 62 perguntas de múltipla escolha fazia com que o processo fosse facilitado. Os questionários foram submetidos a uma revisão e análise de consistência, e após esta análise iniciou-se o processo de criação da planilha. A análise tabular pela padronização e codificação dos dados levou à interpretação em tabelas baseado na frequência relativa e absoluta das respostas (Pinheiro e Callado, 2005; Campos et al., 2004).

Inicialmente foi aplicado um questionário na localidade de Providência para verificar a consistência das perguntas. Este trabalho inicial foi considerado o pré-teste. Em seguida, elaborou-se o questionário definitivo intitulado "Avaliação dos Dessalinizadores de Pentecoste - CE" dividido em dez partes e contendo 62 perguntas. O questionário continha perguntas sobre a caracterização familiar dos habitantes, a caracterização da propriedade, acesso a terra e migração, as fontes de água utilizadas pelos moradores (poço, rio, açude, água do vizinho, dessalinizador, cisterna ou sistema de abastecimento) e o uso da mesma (consumo direto, alimentação, higiene pessoal, consumo animal e agricultura), o aparelho de dessalinização e a água já utilizada pelos moradores antes da implantação do mesmo; procurava-se na mesma sessão saber a quantidade de água adquirida pelas famílias/dia e se esta quantidade era suficiente, os aspectos ambientais das localidades e o destino do rejeito do dessalinizador.

Para facilitar a análise dos dados foi criado um livro de códigos do questionário utilizado em que cada pergunta passava a ter um código associado, assim como cada possível resposta relacionada a esta pergunta, gerando assim 1.377 códigos. A leitura e interpretação deste livro foram auxiliadas por uma planilha eletrônica elaborada no software Microsoft Excel, finalizando o processo de tabulação múltipla e análise estatística descritiva.

Em cada comunidade foram coletadas amostras de água do poço, dessalinizada e de rejeito, para realização das análises: potencial hidrogeniônico $(\mathrm{pH})$, condutividade elétrica $\left(\mathrm{CE}\right.$, em dS m$\left.{ }^{-1}\right)$, sódio $\left(\mathrm{Na}\right.$, em mmolc $\left.\mathrm{L}^{-1}\right)$, potássio $\left(\mathrm{K}\right.$, em $\left.\mathrm{mmol}_{\mathrm{c}} \mathrm{L}^{-1}\right)$ e Cálcio $\left(\mathrm{Ca}, \mathrm{mmol}_{\mathrm{c}}\right.$ $\left.\mathrm{L}^{-1}\right)$. As amostras foram armazenadas em garrafas plásticas e, em seguida, refrigeradas e transportadas em caixa de isopor e analisadas em triplicatas no laboratório de relações solo- 
água-planta do Departamento de Engenharia Agrícola da Universidade Federal do Ceará.

Os dados de qualidade de água foram interpretados de acordo com a Resolução $\mathrm{N}^{\circ} 357$, de 17 de março de 2005 (Brasil, 2005), e de acordo com o Laboratório de Salinidade dos Estados Unidos (Richards, 1954), o University of California Commitee of Consultants (Pizarro, 1985) e Ayers e Westcot (1999).

\section{RESULTADOS E DISCUSSÃO}

Na Tabela 1 verifica-se que dos oito dessalinizadores instalados em Pentecoste, Ceará, apenas quatro estavam em funcionamento. $\mathrm{O}$ equipamento instalado na localidade de Mulungu está em funcionamento há 16 anos e atende a 35 famílias, onde cada família paga $\mathrm{R} \$ 5,00$ por mês e tem direito a 40 litros de água dessalinizada por dia. Na localidade de Muquenzinho o equipamento está em funcionamento há 5 anos e atende 26 famílias, onde cada família paga $\mathrm{R} \$ 5,00$ por mês e tem direito a 20 litros de água dessalinizada por dia. $\mathrm{O}$ dessalinizador da localidade Irapuá atende 62 famílias, e quem paga $\mathrm{R} \$ 0,50$ tem direito a 20 litros por dia, sendo que o mesmo está em funcionamento há 6 anos. Em Lagoa da Porta, o dessalinizador funciona desde 2005, atende um total de 15 famílias, porém o valor e a quantidade de litros não foram estabelecidos, de modo que cada família consome a quantidade que precisa. Os dessalinizadores das localidades Providência e Barra do Lemo foram recuperados, porém as comunidades estão aguardando a religação da energia elétrica, portanto o dessalinizador não está em funcionamento. Já na localidade de Capivara os equipamentos estão aguardando manutenção.

Tabela 1. Situação dos dessalinizadores de Pentecoste-CE (Dezembro de 2009).

\begin{tabular}{lcl}
\hline Localidades & $N^{o}$ de famílias & Situação atual \\
\hline Providência & 13 & Desativado \\
Mulungu & 35 & Em funcionamento \\
Muquenzinho & 26 & Em funcionamento \\
Irapuá & 62 & Em funcionamento \\
Macacos & 58 & Desativado \\
Barra do Lemo & 20 & Desativado \\
Capivara & 32 & Desativado \\
Lagoa da Porta & 15 & Em funcionamento \\
\hline
\end{tabular}

Na Tabela 2, encontram-se os valores de $\mathrm{pH}, \mathrm{CE}, \mathrm{Na}, \mathrm{K}$ e $\mathrm{Ca}$ da água do poço, dessalinizada e rejeito, coletadas nas localidades de Mulungu, Muquenzinho, Irapuá e Lagoa da Porta, onde os equipamentos se encontravam em funcionamento, atendendo a população com água potável. Em geral, os maiores valores de $\mathrm{pH}, \mathrm{CE}, \mathrm{Na}$ e $\mathrm{Ca}$ para água do poço, dessalinizada e rejeito se encontram na localidade de Muquenzinho. Os valores de $\mathrm{pH}, \mathrm{CE}, \mathrm{Na}$ e Ca são elevados na água do poço e do rejeito de todas as localidades citadas na Tabela 2. A elevada concentração de $\mathrm{Na}$ e de outros íons na água do poço e do rejeito, pode contribuir para a salinidade dos solos quando o destino desse rejeito é o solo ou uma lagoa, causando impactos ambientais negativos para as gerações futuras. Os dessalinizadores apresentaram 
grande eficiência, reduzindo consideravelmente a salinidade das águas, porém tornam o $\mathrm{pH}$ relativamente ácido, abaixo dos valores recomendados para o consumo humano.

De acordo com Ayers e Westcot (1999), a disponibilidade de água para as plantas é afetada pela presença de sais no solo e na água. Ainda segundo estes autores, a velocidade com que a água se infiltra no solo é reduzida por teores altos de sódio e baixos de cálcio no solo e na água. Embora 3/4 da superfície terrestre sejam cobertos por água, as expectativas para este século são preocupantes quanto à disponibilidade de água potável para o consumo humano, tanto pelo crescimento populacional como, principalmente, pela poluição dos reservatórios naturais, rios, lagos, depósitos subterrâneos, etc (Holanda et al., 2010).

Os corpos d'água do território nacional seguem classificação e padrões de qualidade determinados pela Resolução 357/2005 do Conselho Nacional do Meio Ambiente (Conama). Esta resolução classifica as águas do Território Nacional em doces (salinidade $<0,5 \%$ ), salobras (salinidade entre 0,5 e 30\%o) e salinas (salinidade $>30 \%$ ), e indica seus usos preponderantes. De acordo com esta resolução, as águas dos poços e do rejeito da Tabela 2 são enquadradas como salobras e a água dessalinizada como água doce (Brasil, 2005).

A média de salinidade das amostras de água do poço e rejeito das localidades de Mulungu, Muquenzinho, Irapuá e Lagoa da Porta é de 4,38 e 5,73 dS m-1, respectivamente (Tabela 2). De acordo com a classificação da água para irrigação (Richards,1954; Pizarro, 1985; Ayers e Westcot, 1999) essas fontes hídricas apresentam elevado risco de salinidade, se enquadrando na classe de salinidade C4. Não são apropriadas para irrigação sob condições normais, porém podem ser usadas ocasionalmente em circunstâncias muito especiais. Os solos devem ser permeáveis, a drenagem adequada, devendo ser aplicada água em excesso para se obter uma boa lixiviação de sais e, mesmo assim, devem ser explorados com culturas altamente tolerantes aos sais. De acordo com o MMA (2005) estas águas se classificam como salobras apresentando valores de condutividade elétrica bem superiores ao limite estabelecido para o consumo humano pela Organização Mundial da Saúde (OMS, 2011) que é de $0,8 \mathrm{dS} \mathrm{m}^{-1}$. Portanto, tanto a água dos poços quanto a água do rejeito são impróprias para os seres humanos.

A média da salinidade das amostras de água dessalinizada das localidades de Mulungu, Muquenzinho, Irapuá e Lagoa da Porta é de $0,08 \mathrm{dS} \mathrm{m}^{-1}$, que de acordo com dados da OMS (2011) pode ser utilizada para consumo humano, visto que o limite preconizado é de até 0,8 $\mathrm{dS} \mathrm{m} \mathrm{m}^{-1}$. Nas estações de tratamento de águas, são várias as unidades cujo controle envolve as determinações de $\mathrm{pH}$. Existe uma condição denominada "pH ótimo" de floculação que corresponde à situação em que as partículas coloidais apresentam menor quantidade de carga eletrostática superficial. Sabe-se que as águas ácidas são corrosivas, ao passo que as alcalinas são incrustantes. Por isso o $\mathrm{pH}$ da água final deve ser controlado, para que os carbonatos presentes sejam equilibrados. $\mathrm{O}$ pH é padrão de potabilidade, devendo os valores nas águas para abastecimento público serem mantidos na faixa de 6,0 e 9,5, de acordo com a Portaria 1469 do Ministério da Saúde. Observando-se os valores de $\mathrm{pH}$ das referidas localidades temos uma média de 5,65, um pouco abaixo do que dita o Ministério da Saúde (Brasil, 2011).

Resultados semelhantes aos encontrados no presente estudo foram obtidos por Monteiro et al. (2009), que avaliaram os dessalinizadores implantados em dez comunidades no semiárido paraibano, com a finalidade de estudar a RAS (Razão de Adsorção de Sódio), a CE (Condutividade Elétrica), e as concentrações de Cálcio, Magnésio e Sódio. Os valores de CE encontrados nos rejeitos por esses autores variaram de 1,05 a 9,28 $\mathrm{dS} \mathrm{m}^{-1}$, com alguns apresentando valores similares aos encontrados nos rejeitos dos dessalinizadores da região de Pentecoste, CE. Nos dois casos observa-se que a maioria dos rejeitos apresenta riscos altos a muito altos de salinização, sendo possível que os riscos de salinização sejam maiores do que os de sodificação do solo. 
Tabela 2. Características físico-químicas de amostras de água de poço, dessalinizada e rejeito, coletadas em diversas localidades de Pentecoste-CE (Dezembro de 2011).

\begin{tabular}{|c|c|c|c|c|c|c|}
\hline Localidades & Amostra & $\mathrm{pH}$ & 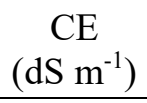 & $\begin{array}{c}\mathrm{Na} \\
\left(\mathrm{mmol}_{\mathrm{c}} \mathrm{L}^{-1}\right)\end{array}$ & $\begin{array}{c}\mathrm{K} \\
\left(\mathrm{mmol}_{\mathrm{c}} \mathrm{L}^{-1}\right)\end{array}$ & $\begin{array}{c}\mathrm{Ca} \\
\left(\mathrm{mmol}_{\mathrm{c}} \mathrm{L}^{-1}\right)\end{array}$ \\
\hline \multirow{3}{*}{ Mulungu } & Poço & 7,1 & 3,5 & 13,7 & 0,4 & 9,5 \\
\hline & Dessalinizada & 5,4 & 0,06 & 0,7 & 0,0 & 0,0 \\
\hline & Rejeito & 6,9 & 4,2 & 14,4 & 0,4 & 1,3 \\
\hline \multirow{3}{*}{ Muquenzinho } & Poço & 7,8 & 5,3 & 37,3 & 0,4 & 5,9 \\
\hline & Dessalinizada & 5,6 & 0,08 & 0,6 & 0,0 & 0,0 \\
\hline & Rejeito & 7,1 & 7,6 & 49,3 & 0,7 & 16,2 \\
\hline \multirow{3}{*}{ Irapuá } & Poço & 7,4 & 3,9 & 18,4 & 0,3 & 12,7 \\
\hline & Dessalinizada & 6,1 & 0,09 & 0,8 & 0,0 & 0,0 \\
\hline & $\underline{\text { Rejeito }}$ & 7,6 & 5,1 & 23,7 & 0,4 & 8,5 \\
\hline \multirow{3}{*}{ Lagoa da Porta } & Poço & 7,0 & 4,8 & 15,8 & 1,2 & 11,6 \\
\hline & Dessalinizada & 5,5 & 0,1 & 0,7 & 0,1 & 0,0 \\
\hline & Rejeito & 6,5 & 6,0 & 17,8 & 1,5 & 15,3 \\
\hline
\end{tabular}

Algumas localidades não apresentavam um dessalinizador funcional, tendo o equipamento funcionado durante algum tempo, mas não estava atendendo a população. $\mathrm{Na}$ Tabela 3 são apresentados os valores cobrados pelo uso da água dessalinizada, as quantidades disponibilizadas para as famílias, a produção diária de água dessalinizada e a quantidade de rejeitos liberados, levando em consideração uma eficiência de $40 \%$ por parte do dessalinizador (Tabela 3). Verifica-se que ocorrem diferenças na gestão do equipamento, o que pode estar associado ao grau de organização das comunidades estudadas.

Tabela 3. Custo pela manutenção dos dessalinizadores ( $\mathrm{R} \$ /$ mês), quantidade (L) de água que as famílias têm acesso por dia, água dessalinizada gerada por dia (L) e quantidade de rejeito produzido diariamente (L) nas localidades de Mulungu, Muquenzinho, Irapuá e Lagoa da Porta, Pentecoste-CE.

\begin{tabular}{lcccc}
\hline Localidade & $\begin{array}{c}\text { Custo pela } \\
\text { Manutenção }\end{array}$ & $\begin{array}{c}\text { Litros/Família/Dia } \\
\text { de Água Tratada }\end{array}$ & $\begin{array}{c}\text { Água } \\
\text { Tratada/Dia }\end{array}$ & Rejeito Produzido/Dia \\
\hline Mulungu & 5,00 & 40 & 1400 & 2100 \\
Muquenzinho & 5,00 & 20 & 520 & 780 \\
Irapuá & 0,50 & 20 & 1240 & 1860 \\
Lagoa da Porta* & - & - & - & - \\
\hline
\end{tabular}

*Não haviam valores estabelecidos.

$\mathrm{Na}$ Tabela 4 estão apresentados os resultados sobre o destino dado ao rejeito gerado pelo dessalinizador nas localidades com equipamento em pleno funcionamento e se as famílias moradoras tinham alguma informação a respeito dos efeitos do rejeito tanto para saúde humana quanto para o meio ambiente. A maior parte das famílias disse usar o rejeito na alimentação animal. Na localidade de Mulungu o rejeito era utilizado para irrigação.

Das 52 famílias que responderam a respeito do conhecimento sobre os efeitos que o rejeito poderia causar ao meio ambiente, apenas seis delas disseram que tinham conhecimento a respeito ou alguma suspeita. As outras 46 famílias não tinham conhecimento algum sobre os possíveis efeitos do rejeito sobre o meio ambiente e saúde humana. 
Tabela 4. Destino dado ao rejeito do dessalinizador e nível de informação dos moradores sobre efeitos do rejeito para o homem e meio ambiente nas localidades de Mulungu, Muquenzinho, Irapuá e Lagoa da Porta, Pentecoste-CE.

\begin{tabular}{lccccc}
\hline \multirow{2}{*}{ Localidade } & \multicolumn{3}{c}{ Destino do rejeito } & \multicolumn{2}{c}{ Conhece os efeitos do rejeito } \\
\cline { 2 - 6 } & Irrigação & Consumo animal & Meio ambiente & sim & não \\
\hline Mulungu & 12 & 2 & - & 3 & 11 \\
Muquenzinho & - & 12 & 1 & 2 & 17 \\
Irapuá & 3 & 7 & 2 & 1 & 15 \\
Lagoa da Porta & - & 2 & - & - & 3 \\
\hline
\end{tabular}

Segundo Azevedo (2012), os principais destinos do rejeito dos dessalinizadores em áreas isoladas de regiões semiáridas são: higiene pessoal (banho), lavagem de louça, sanitário, limpeza geral, dessedentação animal, aquicultura, irrigação em plantações (plantas halófitas, capim elefante entre outras) e produção de sais (cristalizadores ou evaporadores). Araújo et al. (2005), avaliando os sistemas de dessalinização de águas no semiárido no Rio Grande do Norte, encontraram que a disposição do rejeito na maioria das comunidades é feita de forma indevida, sendo lançados ao meio ambiente sem nenhum critério, podendo salinizar o solo devido a alta concentração de sais. Em sua grande maioria, os tanques de evaporação de rejeito apresentam fissuras, e o rejeito sólido é disposto no solo sem nenhum tratamento ou aproveitamento. Entretanto, algumas comunidades fazem o aproveitamento desse concentrado para criação de peixes, irrigação, alimentação animal, uso em descargas sanitárias e lavagens.

Experiências exitosas em outros Estados mostram o rejeito sendo aproveitado para produção de camarões e tilápias vermelhas para engorda e para obter sal com a evaporação do rejeito, produzindo cloreto de sódio, cálcio, magnésio, sulfeto de cálcio e sulfeto de magnésio (Pinheiro e Callado, 2005). Segundo Wanderlei (2009), no Ceará a lavagem de roupas, carros e motos possuem a maior frequência em utilização dos rejeitos $(38 \%)$, mas não há pesquisas mostrando se essas práticas promovem benefícios às pessoas, sendo apenas experiências isoladas e motivadas pela absoluta falta de água de boa qualidade. Mas o que predomina é a drenagem dos rejeitos para terrenos próximos ao sistema e aos cursos de água (60\%), que é uma forma mais prática e de baixo custo de descartá-los.

Outro uso desta água salobra poderá ser para o cultivo hidropônico, que poderá contribuir para o aumento da produção nesta área. Na hidroponia, a salinidade tolerada pelas culturas é maior que no cultivo convencional em solos salinos, devido a maior e constante disponibilidade de água nos diversos tipos de sistemas hidropônicos em relação ao cultivo em solo, e a pouca ou inexistente contribuição do potencial mátrico sobre o potencial total da água, devendo isto representar uma maior absorção de água e nutrientes pelas plantas para uma mesma quantidade de sais (Santos et al., 2010a; 2010b; Dias et al., 2010; Paulus et al., 2010; Cosme et al., 2011; Santos et al., 2011; Silva et al., 2011; Maciel et al., 2012).

A Tabela 5 mostra as fontes e diferentes usos da água nas localidades onde o dessalinizador encontrava-se parado. Nas localidades onde não há um equipamento para dessalinização da água do poço em pleno funcionamento, a fonte de água mais utilizada é o açude, seguido do uso de cisternas. $\mathrm{O}$ uso da água para irrigação na agricultura é quase nulo, o que caracteriza assim uma agricultura quase exclusivamente de sequeiro. $\mathrm{O}$ uso da água do açude em todas as atividades coloca-a como a mais utilizada, porém, para consumo direto e alimentação a água mais utilizada é a retirada das cisternas, e para higiene pessoal, a água do próprio poço. 
Tabela 5. Diferentes fontes e usos de água nas localidades de Macacos, Barra do Leme e Capivara, Pentecoste-CE.

\begin{tabular}{|c|c|c|c|c|c|c|}
\hline \multicolumn{7}{|c|}{ Utilização/Número de Famílias } \\
\hline Localidade & Fonte & $\begin{array}{c}\text { Consumo } \\
\text { direto }\end{array}$ & Alimentação & $\begin{array}{l}\text { Higiene } \\
\text { pessoal }\end{array}$ & $\begin{array}{c}\text { Consumo } \\
\text { animal }\end{array}$ & Irrigação \\
\hline \multirow{8}{*}{ Macacos } & Poço & - & - & - & - & - \\
\hline & Rio & - & - & - & - & - \\
\hline & Açude & 1 & 1 & 7 & 3 & 1 \\
\hline & Vizinhança & - & - & - & - & - \\
\hline & Cisterna & 6 & 6 & - & - & - \\
\hline & Abastecimento & - & - & - & - & - \\
\hline & Cacimba & - & - & - & - & - \\
\hline & Dessalinizador & - & - & - & - & - \\
\hline \multirow{8}{*}{ Barra do Leme } & Poço & - & - & - & - & - \\
\hline & Rio & - & - & - & - & - \\
\hline & Açude & - & 1 & 4 & - & - \\
\hline & Vizinhança & - & - & - & - & - \\
\hline & Cisterna & 4 & 4 & - & - & - \\
\hline & Abastecimento & - & - & - & - & - \\
\hline & Cacimba & - & - & - & - & - \\
\hline & Dessalinizador & - & - & - & - & - \\
\hline \multirow{8}{*}{ Capivara } & Poço & 1 & 3 & 9 & 3 & - \\
\hline & Rio & - & - & - & - & - \\
\hline & Açude & 7 & 7 & 2 & 4 & 1 \\
\hline & Vizinhança & - & - & - & - & - \\
\hline & Cisterna & 1 & 1 & - & - & - \\
\hline & Abastecimento & 1 & 2 & 5 & 2 & - \\
\hline & Cacimba & - & - & - & - & - \\
\hline & Dessalinizador & - & - & - & - & - \\
\hline
\end{tabular}

$\mathrm{Na}$ localidade de Macacos, 7,69\% da população utilizam água do açude para consumo direto, alimentação e irrigação, 53,85\% para higiene pessoal e $23,08 \%$ para consumo animal (Tabela 5). Nesta mesma localidade, $50 \%$ utilizam água da cisterna para consumo direto e $50 \%$ para alimentação. Na localidade de Barra do Leme o uso da água do açude é de $20 \%$ para alimentação e $80 \%$ para higiene pessoal. No caso do uso da água da cisterna, nesta comunidade é de 50\% para consumo direto e alimentação. A comunidade da localidade de Capivara utiliza as mais diversas fontes de água disponíveis para os mais diversos fins. Devese destacar que a maioria utiliza água do açude, onde $33 \%$ do uso desta água são para consumo direto e alimentação.

Nas localidades com dessalinizador em pleno funcionamento, ocorreu o fato das famílias utilizarem água do poço para alimentação e água dessalinizada para consumo direto, como no caso de Mulungu e Lagoa da Porta. Na comunidade de Muquenzinho destaca-se o uso de água dessalinizada para consumo direto e água de cacimba para alimentação, e na comunidade Irapuá destaca-se o uso de água dessalinizada para consumo direto e água de abastecimento 
para alimentação (Tabela 6). Como a água dessalinizada é mantida em algumas das localidades com um preço a se pagar, então o consumo ainda é limitado. A água mais utilizada para higiene pessoal é a de poço (Tabela 6). Na localidade de Mulungu, $66,67 \%$ da população utiliza a água dessalinizada para consumo direto e $28,57 \%$ para alimentação.

Tabela 6. Diferentes fontes e usos de água nas localidades de Mulungu, Muquenzinho, Irapuá e Lagoa da Porta, Pentecoste-CE.

\begin{tabular}{|c|c|c|c|c|c|c|}
\hline \multicolumn{7}{|c|}{ Utilização/Número de Famílias } \\
\hline Localidade & Fonte & $\begin{array}{l}\text { Consumo } \\
\text { direto }\end{array}$ & Alimentação & $\begin{array}{l}\text { Higiene } \\
\text { pessoal }\end{array}$ & $\begin{array}{c}\text { Consumo } \\
\text { animal }\end{array}$ & Irrigação \\
\hline \multirow{8}{*}{ Mulungu } & Poço & - & 6 & 10 & 6 & - \\
\hline & Rio & - & - & 1 & - & - \\
\hline & Açude & - & - & - & 1 & - \\
\hline & Vizinhança & - & - & - & - & - \\
\hline & Cisterna & - & 1 & 1 & 1 & - \\
\hline & Abastecimento & - & 5 & 6 & 3 & - \\
\hline & Cacimba & - & - & - & - & - \\
\hline & Dessalinizador & 14 & 6 & 1 & - & - \\
\hline \multirow{8}{*}{ Muquenzinho } & Poço & 2 & 4 & 4 & 2 & - \\
\hline & Rio & - & - & - & 1 & - \\
\hline & Açude & - & 2 & 1 & - & - \\
\hline & Vizinhança & - & - & - & - & - \\
\hline & Cisterna & - & - & - & - & - \\
\hline & Abastecimento & - & - & - & - & - \\
\hline & Cacimba & 1 & 12 & 14 & - & - \\
\hline & $\underline{\text { Dessalinizador }}$ & 18 & 2 & - & - & - \\
\hline \multirow{8}{*}{ Irapuá } & Poço & 1 & 6 & 7 & & - \\
\hline & Rio & - & 1 & 1 & - & - \\
\hline & Açude & - & - & - & - & - \\
\hline & Vizinhança & - & - & - & - & - \\
\hline & Cisterna & - & - & - & - & - \\
\hline & Abastecimento & 2 & 7 & 8 & - & - \\
\hline & Cacimba & - & - & - & - & - \\
\hline & Dessalinizador & 14 & 2 & & & \\
\hline \multirow{8}{*}{ Lagoa da Porta } & Poço & 1 & 7 & 13 & 9 & 2 \\
\hline & Rio & - & - & - & - & - \\
\hline & Açude & - & - & 1 & - & - \\
\hline & Vizinhança & - & - & - & - & - \\
\hline & Cisterna & 3 & 1 & - & - & - \\
\hline & Abastecimento & - & 1 & 3 & 2 & - \\
\hline & Cacimba & - & - & - & - & - \\
\hline & Dessalinizador & 11 & 6 & - & - & - \\
\hline
\end{tabular}

\section{CONCLUSÕES}

A localidade de Muquenzinho apresenta os maiores valores de $\mathrm{pH}, \mathrm{CE}, \mathrm{Na}$ e $\mathrm{Ca}$ para água do poço, dessalinizada e rejeito, em relação às demais localidades. Os valores de $\mathrm{CE}$ para o rejeito variaram de 4,2 a 7,6 $\mathrm{dS} \mathrm{m}^{-1}$, representando riscos para o ambiente. 
A maior parte do rejeito gerado é utilizada para alimentação animal, e a grande maioria da população, independente da localidade, não tem conhecimento se o rejeito causa algum dano à saúde humana ou ao meio ambiente.

As diversas fontes de água existentes nas localidades não perderam seu uso devido à implantação dos dessalinizadores, porém nas localidades visitadas, onde os equipamentos se encontram em pleno funcionamento, a comunidade se utiliza das águas dessalinizadas geradas por estes equipamentos.

A escassez de água na região, associada à oportunidade para se ter água de boa qualidade, também serve para disciplinar as pessoas a fazer uso racional desse recurso, evitando os desperdícios e o mau uso das fontes de água disponíveis.

\section{AGRADECIMENTOS}

À CAPES, pela concessão da bolsa de estudo do primeiro autor. Ao CNPq e ao INCTSal (Instituto Nacional de Ciência e Tecnologia em Salinidade), pelo apoio financeiro na realização da pesquisa.

\section{REFERÊNCIAS}

AYERS, R. S.; WESTCOT, D. W. A qualidade da água na agricultura. Campina Grande: UFPB, 1999.153p.

ARAÚJO A. L. C.; FONSECA A. L.; VALE M. B.; FERNANDES A. K. S.; GADELHA C. P. F. Avaliação dos sistemas de dessalinização de águas no semiárido no Rio Grande do Norte. In: CONGRESSO BRASILEIRO DE ENGENHARIA SANITÁRIA E AMBIENTAL, 23., 2005, Campo Grande. Resumos... Campo Grande: ABES 2005.

AZEVEDO, J. Processo descentralizado e sustentável de oferta de água dessalinizada em áreas isoladas de regiões semiáridas. Disponível em: http://www2.mre.gov.br/aspa/ semiarido/data/josema_azevedo.htm. Acesso em: 02 fev 2012.

BELTRAN, J. M.; KOO-OSHIMA, S. Water dessalination for agricultural applications. Rome: FAO, 2006. 60p.

BRASIL. Ministério do Meio Ambiente. Resolução n³57, de 17 de março de 2005. Diário Oficial [da] União, n. 53, p. 58-63, 18 mar. 2005.

BRASIL. Portaria $\mathrm{n}^{\mathrm{o}}$ 2.914, de 12 de dezembro de 2011. Dispõe sobre os procedimentos de controle e de vigilância da qualidade da água para consumo humano e seu padrão de potabilidade. Diário Oficial [da] União, 12 dez. 2011.

CAMPOS, R. T.; GOMES, R. K. G.; CAMPOS, K. C. A crise da água no setor agrícola do Ceará: A busca de solução por meio de sistemas de dessalinização. In: CONGRESSO DA SOCIEDADE BRASILEIRA DE ECONOMIA E SOCIOLOGIA RURAL, 43., Cuiabá. Resumos... Cuiabá: UERJ; UFMG, 2004.

COSME, C. R.; DIAS N. S.; OLIVEIRA, A. M.; OLIVEIRA, E. M. M.; SOUSA NETO, O. N. Produção de tomate hidropônico utilizando rejeito da dessalinização na solução nutritiva aplicados em diferentes épocas. Revista Brasileira de Engenharia Agrícola e Ambiental, v. 15, p. 499-504, 2011. http://dx.doi.org/10.1590/S141543662011000500010 
CEARÁ. Assembléia Legislativa. Conselhos de altos estudos e assuntos estratégicos. Fortaleza: INESP, 2008. 174p.

CEARÁ. Superintendência de Obras Hidráulicas. Planilha geral de dessalinizadores. Disponível em: http://www.sohidra.ce.gov.br. Acesso em: 19 jun 2012.

CEARÁ. Superintendência de Obras Hidráulicas. Águas subterrâneas. Disponível em: http://www.sohidra.ce.gov.br. Acesso em: 12 jul. 2011.

DIAS, N. S.; LIRA, R. B.; BRITO, R. F.; SOUSA NETO, O. N.; FERREIRA NETO, M.; OLIVEIRA, A. M. Produção de melão rendilhado em sistema hidropônico com rejeito da dessalinização de água em solução nutritiva. Revista Brasileira de Engenharia Agrícola e Ambiental, v. 14, 2010. http://dx.doi.org/10.1590/S141543662010000700011

FERNANDES, F. B. P.; ANDRADE, E. M. DE; FONTENELE, S. DE B.; MEIRELES, A. C. M.; RIBEIRO, J. A. Análise de agrupamento como suporte à gestão qualitativa da água subterrânea no semiárido cearense. Revista Agro@mbiente On-line, v. 4, n. 2, p. 8695, 2010.

INSTITUTO BRASILEIRO DE GEOGRAFIA E ESTATÍSTICA - IBGE. Cidades: Ceará: pentecoste: infográficos: dados gerais do município. Disponível em: http://cod.ibge.gov.br/1ACH. Acesso em: 19 jun. 2012.

HOLANDA, J. S. DE; AMORIM, J. R. A. DE; FERREIRA NETO, M.; HOLANDA, A. C. DE. Qualidade da água para irrigação. In: GHEYI, H. R.; DIAS, N. DA S.; LACERDA, C. F. DE. Manejo da salinidade na agricultura irrigada: estudos básicos e aplicados. Fortaleza: INCTSAL, 2010. p. 43-59.

MACIEL, M. P.; SOARES, T. M.; GHEYI, H. R.; REZENDE, E. P. L.; OLIVEIRA, G. X. S. Produção de girassol ornamental com uso de águas salobras em sistema hidropônico NFT. Revista Brasileira de Engenharia Agrícola e Ambiental, v. 16, p. 165-172, 2012. http://dx.doi.org/10.1590/S1415-43662012000200006

MEDEIROS, S. S.; GHEYI, H. R.; GALVÃO, C. O.; PAZ, V. P. S. Recursos hídricos em regiões áridas e semiáridas. Campina Grande: Instituto Nacional do Semiárido, 2011. 440 .

MONTEIRO, G. S.; SILVA, J. N.; LESSA LÔBO, H. L. Estudo da razão de adsorção de sódio do rejeito de dessalinizadores implantados no semiárido paraibano. Enciclopédia Biosfera, v. 5, p. 1-6, 2009.

ORGANIZAÇÃO MUNDIAL DA SAÚDE - OMS. Guidelines for drinking-water quality. 4. ed. Genebra, 2011. 564p.

OSTER, J. D.; LETEY, J.; VAUGHAN, P.; WU, L.; QADIR, M. Comparison of transient state include salinity and matric stress effects on plant yield. Agricultural Water Management, v. 103, p. 167-175, 2012. http://dx.doi.org/10.1016/j. agwat.2011.11.011

PAULUS, D.; DOURADO NETO, D.; FRIZZONE J. A.; SOARES, T.M. Produção e indicadores fisiológicos de alface sob hidroponia com água salina. Horticultura Brasileira, v. 28, p. 29-35, 2010. http://producao.usp.br/handle/BDPI/5391 
PINHEIRO, J. C. V.; CALLADO, S. M. Avaliação de desempenho dos dessalinizadores no Ceará. Revista Econômica do Nordeste, v. 36, 2005. http://www.repositorio. ufc.br/handle/riufc/687

PIZARRO, F. Drenaje agrícola y recuperacion de suelos salinos. 2. ed. Madrid: Editorial Española S. A., 1985. 542p.

PORTO, E. R.; AMORIM, M. C. C.; DUTRA, M. T.; PAUlINO, R. V.; BRITO, L. T. L.; MATOS, A. N. B. Rendimento de Atriplex nummularia irrigada com efluentes da criação de tilápia em rejeito da dessalinização de água. Revista Brasileira de Engenharia Agrícola e Ambiental, v. 10, p. 97-103, 2006. http://dx.doi.org/ $10.1590 /$ S1415-43662006000100015

RICHARDS, L. A. (Ed.). Diagnosis and improvement of saline and alkali soils. Washington, D.C.: U.S. Salinity Labratory, 1954. 160p.

SANTOS, A. N.; SILVA, E. F. F.; SOARES, T. M.; DANTAS, R. M. L.; SILVA, M. M. Produção de alface em NFT e Floating aproveitando água salobra e o rejeito da dessalinização. Revista Ciência Agronômica, v. 42, p. 319-326, 2011. http://dx.doi.org/10.1590/S1806-66902011000200009

SANTOS, A. N.; SOARES, T. M.; SILVA, E. F. F.; SILVA, D. J. R.; MONTENEGRO, A. A. A. Cultivo hidropônico de alface com água salobra subterrânea e rejeito da dessalinização em Ibimirim, PE. Revista Brasileira de Engenharia Agrícola e Ambiental, v. 14, p. 961-969, 2010a. http://dx.doi.org/10.1590/S141543662010000900008

SANTOS, R. S. S.; DIAS, N. S.; SOUSA NETO, O. N.; GURGEL, M. T. Uso do rejeito da dessalinização de água salobra no cultivo da alface (Lactuca sativa L.) em sistema hidropônico NFT. Ciência Agrotécnica, v. 34, p. 983-989, 2010 b.

SILVA, F. J. A.; ARAÚJO, A. L.; SOUZA, R. O. Águas subterrâneas no Ceará - poços instalados e salinidade. Revista Tecnologia, v. 28, p. 136-159, 2007. http://dx.doi.org/10.5020/23180730.ano.pi

SIlVA, A. O.; SILVA, D. J. R.; SOARES, T. M.; SILVA, E. F. F.; SANTOS, A. N.; ROLIM, M. M. Produção de rúcula em sistema hidropônico NFT utilizando água salina do Semiárido-PE e rejeito de dessalinizador. Revista Brasileira de Ciências Agrárias, v. 6 , p. 147-155, 2011.

SOARES, T. M.; SILVA, I. J. O.; DUARTE, S. N.; SILVA, E. F. F. Destinação de águas residuárias provenientes do processo de dessalinização por osmose reversa. Revista Brasileira de Engenharia Agrícola e Ambiental, v. 10, p. 730-737, 2006. http://dx.doi.org/10.1590/S1415-43662006000300028

WANDERLEY, R. A. Salinização de solos sob aplicação de rejeito de dessalinizadores com e sem adição de fertilizantes. 2009. 61 f. Dissertação (Mestrado em Engenharia Agrícola) - Universidade Federal Rural de Pernambuco, Recife, 2009. 


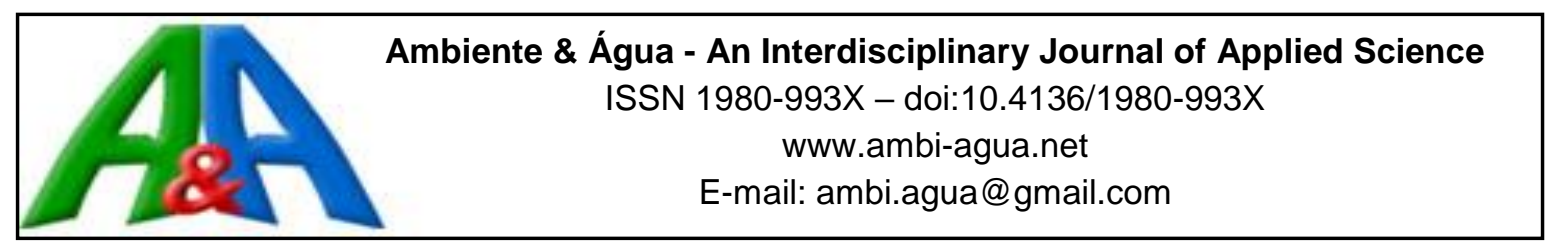

\title{
Comparação entre metodologias de amostragem de água para quantificação de variáveis limnológicas em ambiente lótico
}

\author{
doi:10.4136/ambi-agua.1781
}

Received: 08 Oct. 2015; Accepted: 06 Dec. 2016

\author{
Mayana Silva Bessa Leite; Flávia Mariani Barros*; \\ Danilo Paulúcio da Silva; Romário Oliveira de Santana; \\ Jhones da Silva Amorim; Stênio Rocha de Carvalho
Universidade Estadual do Sudoeste da Bahia (UESB), Itapetinga, BA, Brasil
Departamento de Ciências Exatas e Naturais
*Autor correspondente: e-mail: mariamariani@yahoo.com.br, mayanabessa@hotmail.com,dpaulucio@uesb.edu.br, romarioliver1@hotmail.com,jhones_sa@hotmail.com, steniophn@hotmail.com

\section{RESUMO}

Objetivou-se, com o presente trabalho, avaliar duas metodologias de amostragem de água (amostra coletada na profundidade de $15-30 \mathrm{~cm}$ e amostra integrada), para determinação de variáveis limnológicas em uma seção transversal do rio Catolé Grande, em diferentes níveis de vazão. Foram quantificadas as variáveis turbidez, $\mathrm{pH}$, condutividade elétrica, oxigênio dissolvido e coliformes totais. A comparação dos resultados obtidos, segundo as diferentes metodologias de coleta utilizadas foi realizada utilizando os índices estatísticos eficiência do modelo e coeficiente de determinação e por meio de análise de regressão linear. Houve pequena influência das metodologias de amostragem em relação às variáveis turbidez, condutividade e coliformes totais. Para a variável $\mathrm{pH}$, a amostragem realizada de $15-30 \mathrm{~cm}$ de profundidade ocasionou superestimativa dos valores quando comparados à amostra integrada. Com relação à variável oxigênio dissolvido, os valores obtidos a partir da amostragem de $15-30 \mathrm{~cm}$ tedem a superestimativas quando as concentrações são inferiores a $6,5 \mathrm{mg} \mathrm{L} \mathrm{L}^{-1}$, entretanto, quando a concentação é superior a esse valor, esse tipo de amostragem tende a subestimar quando comparada aos valores obtidos por meio da amostra integrada.

Palavras-chave: qualidade da água, pontos de amostragem, vazão.

\section{Comparison of different water sampling methods to quantify limnological variables in a lotic environment}

\begin{abstract}
This study evaluated water sampling methodologies for determining limnological variables in a cross section of the Catole Grande River at different flow rates. Samples were collected at depths of $15-30 \mathrm{~cm}$ and compared with integrated samples. The variables of turbidity, $\mathrm{pH}$, electrical conductivity, dissolved oxygen and total coliforms were quantified. The results were compared, according to the different collection methodologies, using the statistical index, model efficiency, coefficient of determination, and linear regression analysis. There was little influence of the sampling methodologies in relation to turbidity, conductivity
\end{abstract}


and total coliforms variables. For the $\mathrm{pH}$ variable, the sampling performed at $15-30 \mathrm{~cm}$ depth caused overestimation when compared to the integrated sample. Regarding the dissolved oxygen variable, the values obtained using $15-30 \mathrm{~cm}$ samples tend to overestimate when the concentrations are lower than $6.5 \mathrm{mg} \mathrm{L}^{-1}$; however, when the concentration is higher than this value, this type of sampling tends to underestimated when compared to values obtained using the integrated samples.

Keywords: flow rate, sampling points, water quality.

\section{INTRODUÇÃO}

Para programas de amostragem é importante considerar que a qualidade da água superficial pode variar conforme o local e o tempo. Na seleção do ponto para coleta das amostras em cursos d'água, dois aspectos estão envolvidos: a definição da seção transversal e a cota na posição a ser monitorada (Hynes, 1970).

A Companhia Ambiental do Estado de São Paulo (CETESB, 1988) sugere que coletas de água sejam feitas na calha central do rio na profundidade de 15 a $30 \mathrm{~cm}$. No entanto, a coleta realizada desta forma pode não suprir a necessidade de estudo para alguns casos específicos, sendo necessário estudo mais detalhado das variáveis de qualidade da água ao longo da seção transversal de um rio. Isto pode ser confirmado em estudo realizado por Barros et al. (2012) no Rio Turvo Sujo - MG, no qual os autores recomendaram, nas condições por eles avaliadas, que a amostragem seja feita a $20 \mathrm{~cm}$ de profundidade em relação à superfície e considerando-se a amostra integrada composta por amostras coletadas em três pontos na seção transversal do curso d'água (esquerdo, central e direito) para as variáveis condutividade elétrica, fósforo total dissolvido, fósforo inorgânico dissolvido, amônio e nitrato. Para as variáveis oxigênio dissolvido, turbidez, $\mathrm{pH}$, fósforo total, fósforo inorgânico dissolvido e nitrogênio total, recomenda-se amostragem integrada composta por amostras de água coletadas em três pontos (superfície, meio e fundo), na coluna central do curso d'água (Barros et al., 2012).

Partindo-se desse pressuposto e considerando a escassez estudos que visem comparar metodologias de amostragem em ambientes lóticos que não sofrem influência de contaminação por fontes pontuais de poluição, o objetivo do presente estudo foi comparar duas metodologias utilizadas para amostragem de água em seção transversal de um ambiente lótico.

\section{MATERIAL E MÉTODOS}

A seção transversal monitorada considerada neste estudo está situada no rio Catolé Grande, com coordenadas geográficas $15^{\circ} 14^{\prime} 6,3^{\prime \prime}$ s e $40^{\circ} 16^{\prime} 30,7 " \mathrm{w}$, sendo este pertencente à bacia hidrográfica do rio Pardo no Estado da Bahia. A bacia hidrografica do rio Catolé Grande está contida entre os paralelos 8379377 e 8300757 m e entre os meridianos 299725 e 379475 m em coordenadas UTM (zona 24).

No local onde foram realizadas as coletas das amostras de água do rio Catolé Grande, a largura média da seção transveral em estudo variou entre 14,2 e $15 \mathrm{~m}$ e a profundidade média entre 0,57 e 1,03 m. Foram realizadas seis coletas em diferentes épocas do ano de 2013, nas quais as vazões do rio variaram de $4,33 \mathrm{~m}^{3} \mathrm{~s}^{-1}$ a $11,25 \mathrm{~m}^{3} \mathrm{~s}^{-1}$; esta faixa de vazão apresenta uma permanência de $43 \%$ na série histórica da bacia (série histórica de 56 anos, estação: 53780000).

As metodologias de coleta de águas superficiais avaliadas no presente estudo foram: metodologia proposta na NBR 9897/87, em que se recomenda a obtenção de uma amostra 
integrada por amostras simples coletadas em diferentes pontos da seção avaliada (a depender da largura e profundidade da seção); metodologia proposta pela CETESB (1988) na qual se recomenda a coleta da amostra no centro da seção transversal de 15 a $30 \mathrm{~cm}$ de profundidade do curso d'água.

No primeiro método, para a escolha dos pontos de amostragem, a seção do curso d'água foi subdividida em três subseções de igual largura. As amostras foram coletadas no meio de cada subseção, à metade da profundidade.

Para a análise de cada metodologia, a quantificação das variáveis limnológicas foi realizada em triplicata. Em cada amostra de água coletada, foi quantificado o $\mathrm{pH}$, a turbidez (TUR), a condutividade elétrica (CE), o oxigênio dissolvido (OD) e a contagem de coliformes totais (CT), segundo metodologias descritas em Matos (2012), baseadas em APHA (2005).

A comparação das metodologias de amostragem foi realizada utilizando o coeficiente de determinação $\left(\mathrm{R}^{2}\right)$, o índice de eficiência do modelo (EF) e análise de regressão linear.

Para a medição da velocidade da água na seção transversal do rio Catolé Grande por ocasião de cada campanha de coleta de água utilizou-se molinete hidrométrico digital marca Global Water, modelo FP211. Os procedimentos para medição de vazão foram adotados de acordo com metodologia descrita em CETESB (2011).

\section{RESULTADOS E DISCUSSÃO}

Na Figura 1 é apresentada a comparação dos valores de turbidez (TUR) observados em amostras de água coletadas em uma seção transversal do rio Catolé Grande, para diferentes níveis de vazão, obtidos segundo duas metodologias de amostragem: CESTESB (1988) (Mc) e NBR 9897/87 (Mnbr). Também se encontram representados, na mesma figura, a linha de tendência ajustada a partir dos dados de turbidez obtidos considerando a metodologia $\mathrm{Mc}$ em função da Mnbr, os índices $\mathrm{R}^{2}$, EF e a reta identidade. A reta identidade representa um alinhamento em que os valores obtidos pelas duas metodologias de amostragem seriam iguais.

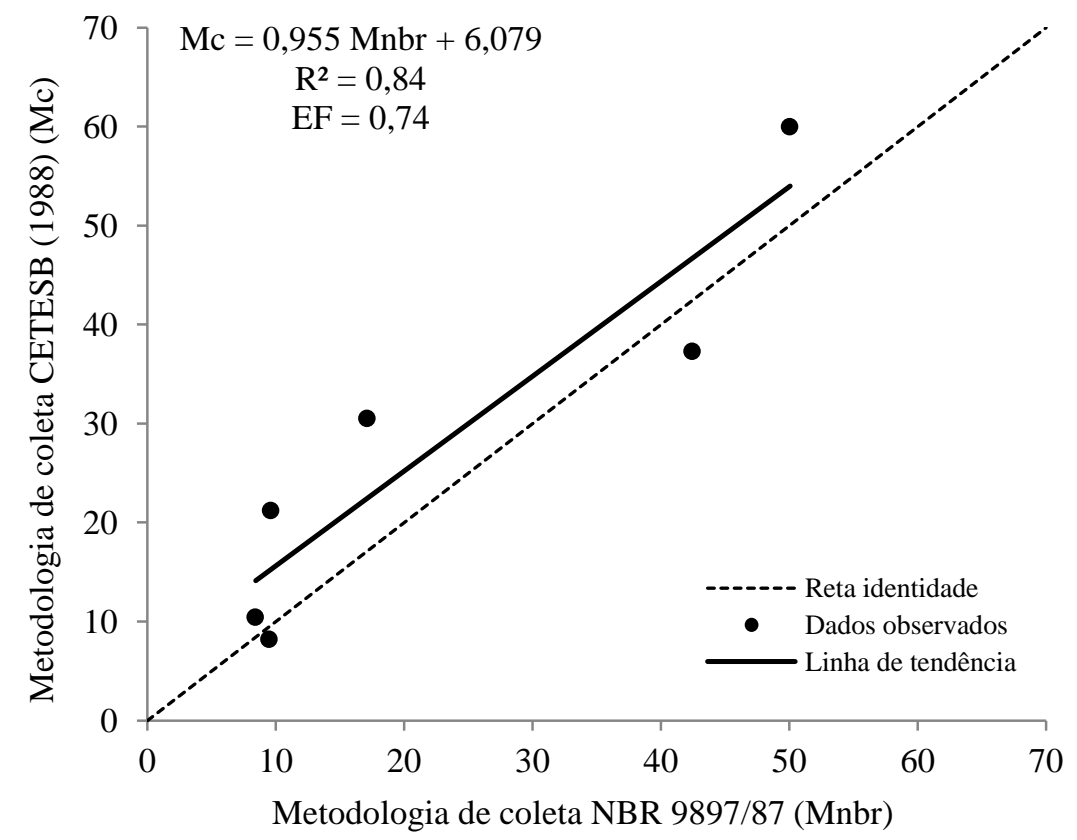

Figura 1. Valores de turbidez em UNT (TUR) em amostras de água coletadas considerando-se a metodologia de coleta da CETESB (1988) versus os obtidos em amostras coletadas seguindo-se a metodologia da NBR 9897/87, em diferentes vazões em uma seção transversal no rio Catolé Grande. 
De acordo com a Figura 1, observa-se semelhança entre metodologias de amostragem para esta variável, uma vez que o coeficiente de determinação $\left(\mathrm{R}^{2}\right)$ e o índice de eficiência das metodologias (EF) apresentaram valores altos, 0,84 e 0,74 respectivamente. Embora na maioria das campanhas de coleta, a amostragem realizada segundo a CETESB (1988) ter indicado valores maiores de turbidez em relação à amostragem realizada segundo a NBR 9897/87 (ABNT, 1987), nota-se na função que o coeficiente angular está próximo a 1 e o coeficiente linear, apesar de não ter sido zero, apresenta um valor baixo quando observa-se a escala de valores desta variável, indicando condição de semelhança entre as metodologias de amostragem.

As metodologias de amostragem provavelmente apresentaram condição de semelhança devido à presença de partículas finas em suspensão, como silte e argila. Esses tipos de particulas possuem distribuição homogênea ao longo da coluna liquída de dada seção de um curso d'água. Assim, independente da amostragem ter sido feito na metade ou a $30 \mathrm{~cm}$ de profundidade, a distribuição homogênea das particulas tende a conduzir valores de turbidez próximos.

Na Figura 2 é apresentada a comparação dos valores de potencial hidrogeniônico ( $\mathrm{pH}$ ) observados em uma seção transversal do rio Catolé Grande em diferentes níveis de vazão, obtidos segundo duas metodologias de amostragem: CESTESB (1988) (Mc) e NBR 9897/87 (Mnbr). Também se encontra representado, nesta figura, a linha de tendência, os índices $\mathrm{R}^{2} \mathrm{e}$ EF e a reta identidade.

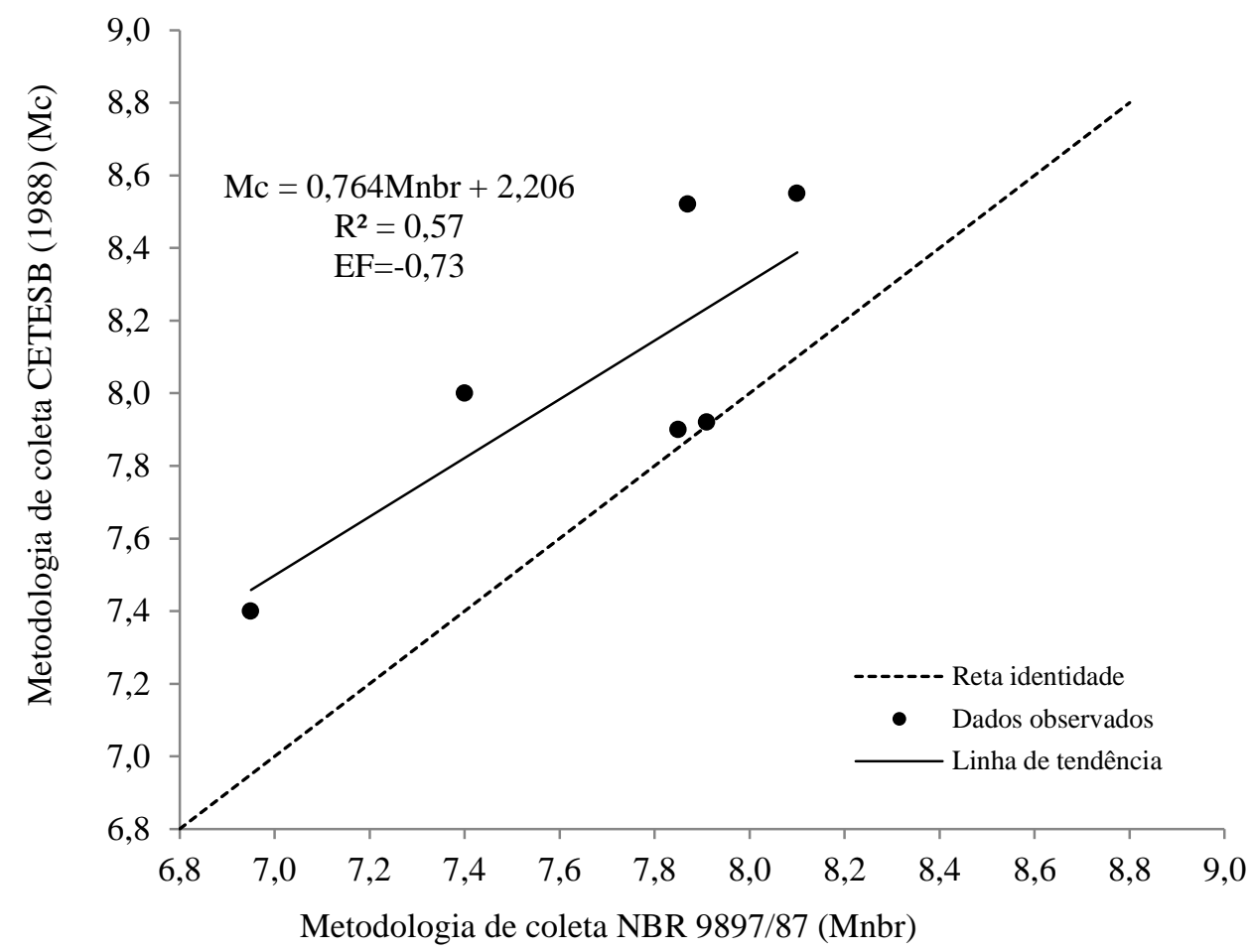

Figura 2. Valores de potencial hidrogeniônico $(\mathrm{pH})$ em amostras de água coletadas considerando-se a metodologia de coleta da CETESB (1988) versus os obtidos em amostras coletadas seguindo-se a metodologia da NBR 9897/87, em diferentes vazões em uma seção transversal no rio Catolé Grande. 
De acordo com a Figura 2, nota-se comportamento distinto entre o resultado obtido a partir das metodologias de amostragem para esta variável, onde o $\mathrm{R}^{2}$ e o EF apresentaram valores baixos, 0,57 e - 0,73, respectivamente. Além disso, é possível observar que a função apresenta um coeficiente angular que não é próximo a 1 e um coeficiente linear alto em relação a escala de valores desta variável, indicando que não há condição de semelhança entre as metodologias de amostragem adotadas.

Verifica-se que os valores na concentração do pH são influenciados pela metodologia de amostragem. Desta forma, foi observado que houve tendência da amostragem realizada segundo a metodologia da CETESB conduzir a maiores valores de $\mathrm{pH}$ quando comparados com os valores obtidos a partir de amostras coletadas segundo a proposição da NBR 9897/87. Nota-se ainda que a diferença dos valores de $\mathrm{pH}$ obtidos segundo as metodologias de amostragem tende a aumentar com redução do $\mathrm{pH}$.

Generoso et al. (2010) analisaram variáveis de qualidade de água neste mesmo rio, em diferentes épocas e pontos de uma seção transversal. Os autores observaram que o pH apresentou diferentes valores em relação aos distintos pontos de coleta e em relação às épocas avaliadas, corroborando com os resultados encontrados no presente trabalho.

Barros et al. (2012), com o objetivo de comparar a distribuição quantitativa de algumas variáveis de qualidade de água e verificar qual o local mais apropriado para coleta de água em uma seção transversal do Rio Turvo Sujo, Minas Gerais, observaram que houve diferença significativa entre as variáveis analisadas e os pontos de amostragem, assim como constatado no presente trabalho. Os autores recomendam para a variável $\mathrm{pH}$ a amostragem integrada constituída por amostras simples coletadas em três pontos (superfície, meio e fundo) na coluna central do curso d'água.

Na Figura 3 é apresentada a comparação dos valores de condutividade elétrica (CE) observados em uma seção transversal do rio Catolé Grande em diferentes níveis de vazão, obtidos segundo duas metodologias de amostragem: CESTESB (1988) (Mc) e NBR 9897/87 (Mnbr). De acordo com os dados apresentados na Figura 3 é possível observar condição de semelhança entre as metodologias de amostragem para esta variável, onde o $R^{2}$ e o EF apresentaram valores altos, 0,98 nos dois índices. Além disso, a função apresenta um coeficiente angular bem próximo a 1 e, embora tenha apresentado coeficiente linear diferente de zero, o valor encontrado de 2,170 é muito baixo, tendo em vista a escala de valores encontrados de CE.

A condição de semelhança entre as metodologias de amostragem ocorreu provavelmente devido à dispersão dos íons dissolvidos ser uniforme na seção transversal e no decorrer das verticais do curso d'água, não havendo aumento ou diminuição nos valores desta variável por nenhuma das metodologias de amostragem adotadas.

Em estudo realizado por Oliveira et al. (2008) em riachos da microbacia do rio São Francisco Verdadeiro - PR, com o objetivo de caracterizar espacial e temporalmente os riachos em função de fatores limnológicos, os autores verificaram que a condutividade elétrica não apresentou diferenças significativas espacialmente ao longo dos pontos de amostragem, o que também foi verificado no presente trabalho.

Barros et al. (2012), com o objetivo de comparar a distribuição quantitativa de algumas variáveis de qualidade de água e verificar o local mais apropriado para coleta de amostras de água em uma seção transversal do Rio Turvo Sujo, Minas Gerais, observaram que houve diferença significativa entre as variáveis analisadas e os pontos de amostragem. Os autores recomendaram que, para a variável condutividade elétrica, a amostragem seja realizada a $20 \mathrm{~cm}$ de profundidade em relação à superfície, com amostra integrada composta por amostras simples coletadas em três pontos (esquerdo, central e direito) do curso d'água. 


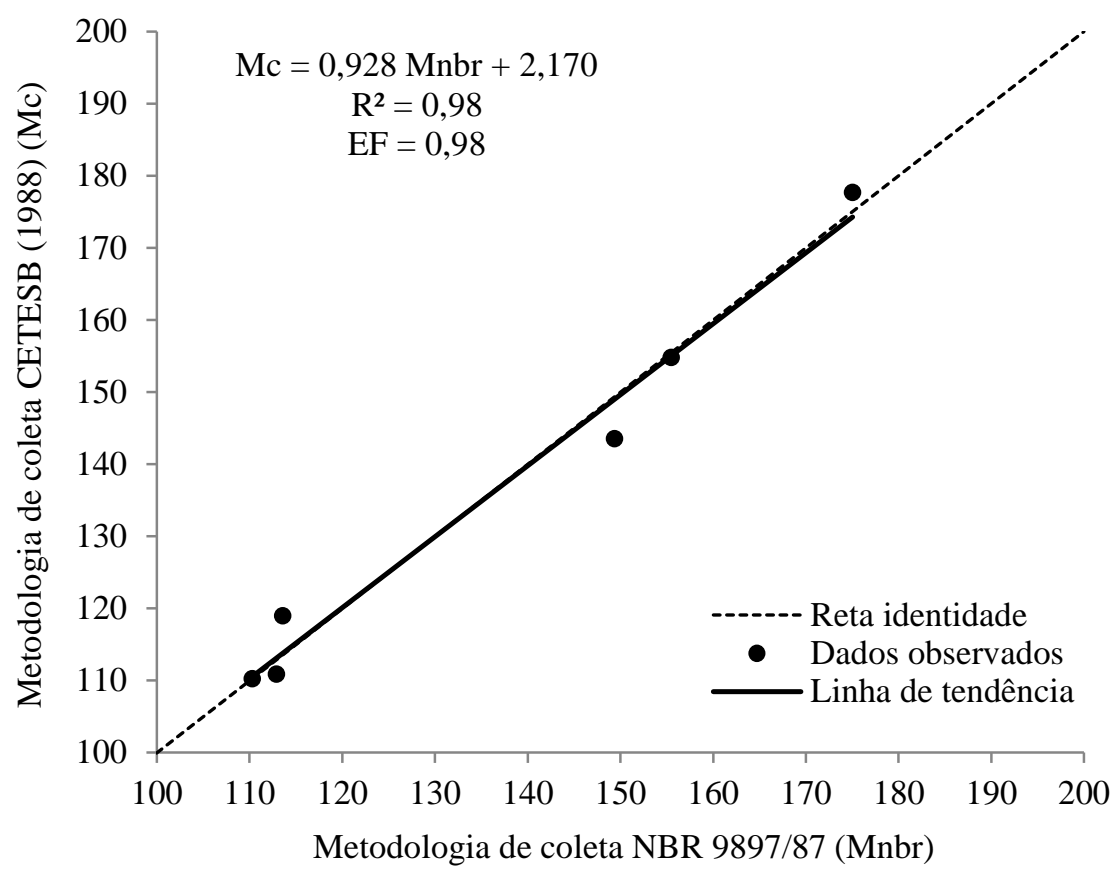

Figura 3. Valores de condutividade elétrica em $\mu \mathrm{S} \mathrm{cm}^{-1}$ (CE) em amostras de água coletadas considerando-se a metodologia de coleta da CETESB (1988) versus os obtidos em amostras coletadas seguindo-se a metodologia da NBR 9897/87, em diferentes vazões em uma seção transversal no rio Catolé Grande.

Na Figura 4 é apresentada a comparação dos valores de oxigênio dissolvido (OD) observados em uma seção transversal do rio Catolé Grande em diferentes níveis de vazão, obtidos segundo duas metodologias de coleta: CESTESB (1988) (Mc) e NBR 9897/87 (Mnbr). De acordo com os dados apresentados na Figura 4 nota-se que não houve grandes semelhanças entre as metodologias de amostragem para esta variável. Apesar do $\mathrm{R}^{2}$ e o EF, apresentarem valores moderados, 0,79 e 0,70 respectivamente, a função apresenta um coeficiente angular distante de 1 e um coeficiente linear muito alto para a escala de valores de OD obtidos, indicando que não há uma condição de semelhança entre as metodologias de amostragem.

$\mathrm{Na}$ amostragem realizada segundo a CETESB (1988) foi constatado que em duas das coletas houve o aumento nos valores de OD em relação a amostragem realizada segundo a NBR 9897/87. Segundo Barros et al. (2012) a taxa de reintrodução de oxigênio dissolvido em águas naturais por meio da superfície depende das características hidráulicas e é proporcional à velocidade, sendo que a taxa de reaeração superficial em uma cascata é maior do que a de um rio de velocidade normal, que por sua vez, apresenta taxa superior à de uma represa, onde a velocidade normalmente é bastante baixa. No presente trabalho a velocidade da água foi cerca de $50 \%$ maior no centro da seção $\left(0,6 \mathrm{~m} \mathrm{~s}^{-1}\right)$ em relação às margens $\left(0,47 \mathrm{~m} \mathrm{~s}^{-1}\right)$, assim como, na superfície em relação à profundidade da coluna d'água. Desta forma era esperado que realmente houvesse diferença entre as metodologias de amostragem.

Em estudo realizado por Rocha et al. (2010) neste mesmo rio, os autores verificaram que para a variável oxigênio dissolvido, os valores obtidos nas amostragens realizadas à profundidade de $0-20 \mathrm{~cm}$ foram sempre superiores aos valores referentes a amostragem realizada por integração vertical com o auxílio do amostrador de sedimentos. Os autores concluíram que essa situação pode ter sido ocasionada, devido ao fato de, na parte mais próxima ao fundo do rio, haver grande quantidade de sedimentos, os quais estão relacionados a maior demanda de oxigênio e, consequentemente, diminuição nos valores de oxigênio 
dissolvido. Este fato pode estar associado aos resultados encontrados no presente trabalho, onde houve o aumento nos valores desta variável na Mc em relação a Mnbr.

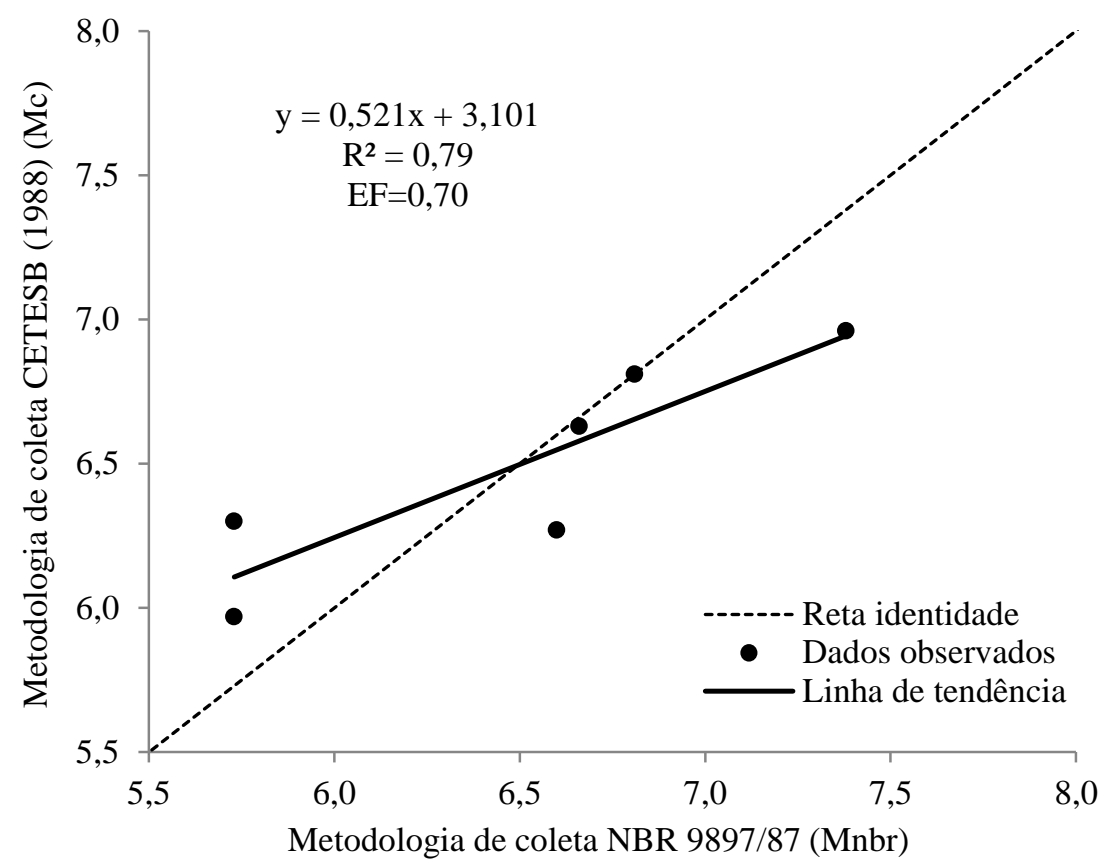

Figura 4. Valores de oxigênio dissolvido em $\mathrm{mg} \mathrm{L}^{-1}$ (OD) em amostras de água coletadas considerando-se a metodologia de coleta da CETESB (1988) versus os obtidos em amostras coletadas seguindo-se a metodologia da NBR 9897/87, em diferentes vazões em uma seção transversal no rio Catolé Grande.

Generoso et al. (2010), avaliando variáveis de qualidade de água no rio Catolé Grande, em diferentes épocas e pontos distintos de uma seção transversal, também encontraram grandes variações na concentração de oxigênio dissolvido em relação às observadas em amostras coletadas em outros pontos do curso d'água.

Na Figura 5 é apresentada a comparação dos valores de contagem de coliformes totais (CT) em amostras de água coletadas em uma seção transversal do rio Catolé Grande, em diferentes níveis de vazão, obtidos segundo as já referidas duas metodologias de coleta. Para essa mesma variavel foi observado condição de semelhança entre as metodologias de amostragem em relação a esta variável, visto que o $\mathrm{R}^{2}$ e o EF apresentaram valores altos, 0,90 nos dois índices (Figura 5). Além disso, a função apresenta coeficiente angular bem próximo a 1 e coeficiente linear com valor baixo em relação a escala de valores de CT.

Foram registrados valores mais próximos entre si para esta variável ao longo da seção transversal e verticais avaliadas no curso d'água, indicando que houve grandes semelhanças entre as metodologias de amostragem. Tal comportamento ocorreu, provavelmente, em viturde de que a maior parte das bactérias encontradas nos CT, sejam encontradas juntamente com os sedimentos finos em suspensão, os quais têm uma distribuição uniforme no decorrer do perfil.

De acordo com von Sperling (2007), as bactérias do grupo coliforme estão presentes no intestino humano e de animais de sangue quente, sendo eliminadas nas fezes em números elevados. Entretanto, o grupo dos coliformes inclui bactérias não exclusivamente de origem fecal, podendo ocorrer naturalmente no solo, água e plantas. Neste sentido, juntamente com os sedimentos seguem possíveis contaminantes, dentre eles as bactérias que compõem os CT provindos de fezes de animais. 
De modo geral, avaliando as metodologias de amostragem adotadas em relação as variáveis limnológicas analisadas, é possível observar que embora tenha ocorrido diferença entre as metodologias de amostragem, para algumas variáveis, esta não foi suficiente para modificar a condição de qualidade das águas do curso d'água (água doce classe 2), segundo a Resolução no 357 do CONAMA (2005), na seção transversal analisada no rio Catolé Grande. No entanto, para estudos voltados para caracterização limnológica das águas do curso d'água, nota-se que houve diferenças entre as metodologias de amostragem adotadas para a maior parte das variáveis.

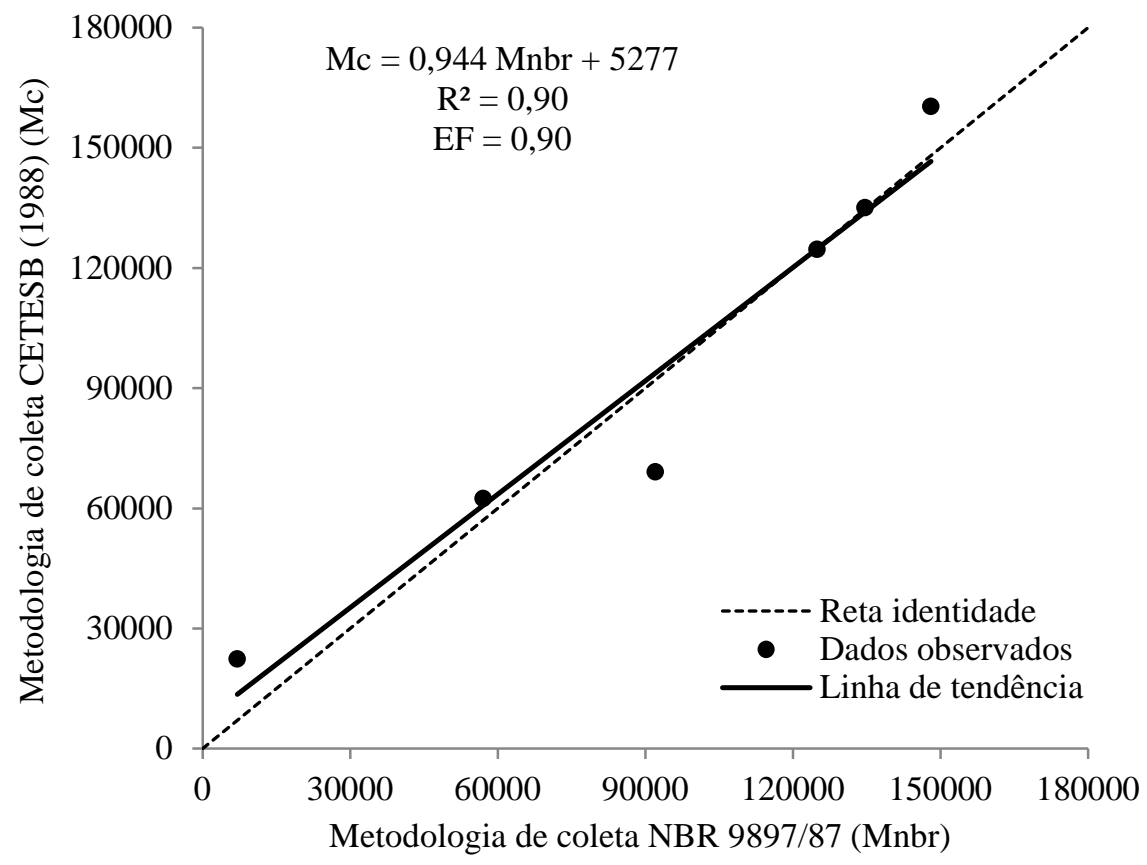

Figura 5. Valores de coliformes totais NMP $100 \mathrm{~mL}^{-1}$ (CT) em amostras de água coletadas considerando-se a metodologia de coleta da CETESB (1988) versus os obtidos em amostras coletadas seguindo-se a metodologia da NBR 9897/87, em diferentes vazões em uma seção transversal no rio Catolé Grande.

Vale salientar que estas metodologias de amostragem podem ser utilizadas para a determinação das variáveis limnológicas analisadas no presente estudo, em cursos d'água com características hidrológicas semelhantes as do rio Catolé Grande e em locais onde não há contaminação por fontes pontuais de poluição à montante.

\section{CONCLUSÃO}

Tendo por base os resultados obtidos, pode-se concluir que:

Houve pequena influência das metodologias de amostragem da CETESB (1988) e NBR 9897/87 em relação às variáveis limnológicas turbidez, condutividade elétrica e coliformes totais em amostras de água coletadas em uma seção transversal do rio Catolé Grande.

Para a variável pH a amostragem realizada segundo a CETESB (1988) ocasionou superestimativa dos valores quando comparados à amostra integrada enquanto que, em relação à variável oxigênio dissolvido os valores obtidos a partir deste tipo de amostragem apresentaram tendência de superestimativas quando as concentrações foram inferiores a $6,5 \mathrm{mg} \mathrm{L}^{-1}$, e subestimativas quando as concentrações foram superiores a esse valor. 
Em nenhum dos casos, a diferença entre os dois tipos de amostragem foi suficiente para modificar a condição de qualidade do curso d'água.

\section{AGRADECIMENTOS}

À Fundação de Amparo à Pesquisa do Estado da Bahia (FAPESB) e ao Conselho Nacional de Pesquisa e Desenvolvimento (CNPq) pelo apoio financeiro concedido para realização desta pesquisa (termo de outorga n. PPP0062/2011). À Universidade Estadual do Sudoeste da Bahia pelas bolsas concedidas.

\section{REFERÊNCIAS}

ASSOCIAÇÃO BRASILEIRA DE NORMAS TÉCNICAS. NBR 9897: planejamento de amostragem de efluentes líquidos e corpos receptores - procedimento. Rio de Janeiro, 1987. $14 \mathrm{p}$.

BARROS, F. M.; MARTINEZ M. A.; MATOS A. T. de; MOREIRA, D. A. Distribuição quantitativa de variáveis de qualidade da água coletada em diferentes pontos de um perfil transversal do rio turvo sujo - MG. Engenharia na agricultura, v. 20, n. 1, p. 60 69, 2012.

COMPANHIA DE TECNOLOGIA DE SANEAMENTO AMBIENTAL DO ESTADO DE SÃO PAULO - CETESB. Guia de coleta e preservação de amostras de água. São Paulo, 1988. $160 \mathrm{p}$.

COMPANHIA DE TECNOLOGIA DE SANEAMENTO AMBIENTAL DO ESTADO DE SÃO PAULO- CETESB. Guia nacional de coleta e preservação de amostras: água, sedimento, comunidades aquáticas e efluentes líquidos. São Paulo: CETESB; Brasília: ANA, 2011. 325 p.

CONSELHO NACIONAL DO MEIO AMBIENTE (Brasil) - CONAMA. Resolução n. ${ }^{\circ}$ 357, de 17 de Março de 2005. Dispõe sobre a classificação dos corpos de água e diretrizes ambientais para o seu enquadramento, bem como estabelece as condições e padrões de lançamento de efluentes, e dá outras providências. Diário Oficial [da] União, Brasília, DF, n. 53, 18 mar. 2005.

GENEROSO, T. N.; FRAGA, D. S.; TAGLIAFERRI, C.; ROSA, R. C. C. Influência do local de amostragem nos valores de variáveis de qualidade de água em uma seção transversal do rio Catolé - BA, Enciclopédia Biosfera, v. 6, n. 11, 2010.

HYNES, H. B. N. The ecology of running waters. 3. ed. Liverpool: University Press, 1970. $555 \mathrm{p}$.

MATOS, A. T. de. Qualidade do meio físico e ambiental. 1.ed. Viçosa: Ed. UFV, 2012. 150 p.

OLIVEIRA, L. C.; GOMES, B. M.; BAUMGARTNER, G.; SEBASTIEN, N. Y. Variação espacial e temporal dos fatores limnológicos em riachos da microbacia do rio são francisco verdadeiro - PR. Engenharia Agrícola, v. 28, n. 4, p. 770-781, 2008. http://dx.doi.org/10.1590/S0100-69162008000400017

ROCHA, F. A.; SATURNINO, M. C. O. MELO, A. R. B.; BARROS, F. M.; BARRETO, L. V. Variáveis de qualidade de água influenciadas pelo tipo e época de amostragem, no rio Catolé - BA. Enciclopédia Biosfera, v. 6, n. 11, 2010. 
Von SPERLING, M. Estudos e modelagem da qualidade da água de rios. Belo Horizonte: Ed. UFMG, 2007, 588 p. 


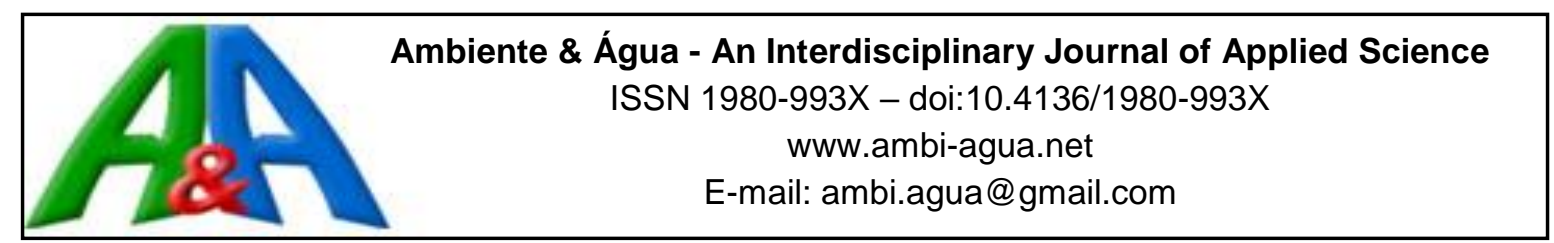

\title{
Caracterização hidroambiental de nascentes
}

\author{
doi:10.4136/ambi-agua.1909 \\ Received: 01 Apr. 2016; Accepted: 19 Oct. 2016 \\ Mariana Santos Leal ${ }^{1 *}$; Kelly Cristina Tonello ${ }^{1}$; \\ Herly Carlos Teixeira Dias ${ }^{2}$; Rafael Mingoti ${ }^{3}$ \\ ${ }^{1}$ Universidade Federal de São Carlos (UFSCAR), Sorocaba, SP, Brasil \\ Programa de Pós-graduação em Planejamento e Uso dos Recursos Renováveis (PPGPUR) \\ ${ }^{2}$ Universidade Federal de Viçosa (UFV), Viçosa, MG, Brasil \\ Departamento de Engenharia Florestal \\ ${ }^{3}$ Empresa Brasileira de Pesquisa Agropecuária (EMBRAPA), Campinas, SP, Brasil \\ Departamento de Gestão territorial \\ *Autor correspondente: e-mail: mari_floresta@hotmail.com, \\ kellytonello@ufscar.br, herly@ufv.br, rafael.mingoti@embrapa.br
}

\section{RESUMO}

As nascentes consistem em um afloramento do lençol freático que dão origem aos fluxos d'água. Essas águas passam a formar a rede de drenagem. Os impactos ambientais negativos, provocados em qualquer porção da bacia podem interferir na quantidade e qualidade da água e, dependendo do impacto, formas ou alternativas diferentes de manejo deverão ser implantadas visando à melhoria do ambiente. Este trabalho teve por objetivo a caracterização das nascentes da bacia do córrego Itanguá, Capão Bonito, SP, Brasil, quanto ao tipo e estado de conservação, assim como a identificação de impactos ambientais negativos presentes. Quanto ao tipo, as nascentes foram classificadas em pontual ou difusa, e o estado de conservação obtido por meio da avaliação macroscópica foi ranqueado em ótimo, bom, razoável, ruim e péssimo. Na bacia foram identificadas 19 nascentes e, das 15 que foram visitadas, nove foram classificadas como pontuais, enquanto que seis foram difusas. Quanto ao estado de conservação, duas foram classificadas como ótimas, 12 como boas e uma como razoável. Também a partir da avaliação macroscópica foi observado que a presença de espécies exóticas, tanto animal (Sus scrofa) como vegetal (Pinus spp.), e a ausência de vegetação nativa na área de preservação permanente foram os impactos ambientais negativos mais frequentes. A metodologia empregada se mostrou eficiente como análise qualitativa visual da situação das nascentes e como fornecedoras de informação para subsidiar ações para a conservação da água na Floresta Nacional de Capão Bonito, SP, Brasil.

Palavras-chave: avaliação macroscópica, conservação da água, Sus scrofa.

\section{Hydroenvironmental characterization of springs}

\section{ABSTRACT}

Springs consist of an upwelling of groundwater from which water flows. This water then forms the drainage network. The negative environmental impacts caused in any portion of the basin may affect the quantity and quality of water. This study characterized the springs of Itanguá watershed, Capão Bonito, SP, considering their types, their conservation status, and 
the presence of negative environmental impacts. As for the type, springs were classified as "point" or "diffuse" and, regarding conservation status, they were ranked as "excellent", "good", "fair", "bad" and "very bad" based on macroscopic evaluation. Nineteen springs were identified and 15 visited; of these, nine were classified as "point", and six as "diffuse." With respect to conservation status, two springs were classified as "excellent", 12 as "good", and one as "fair". The presence of exotic species was observed by macroscopic evaluation, such as animal (boar) and vegetation (Pinus spp.). The lack of vegetation in "permanent preservation areas" was the most frequently observed environmental impact found. The methods used were efficient as a first analysis of the situation of the springs and to provide information to support programs to improve water conservation in the Floresta Nacional de Capão Bonito, SP.

Keywords: macroscopic evaluation, Sus scrofa, water conservation.

\section{INTRODUÇÃO}

As nascentes consistem em um afloramento do lençol freático que dão origem aos fluxos d'água formadores da rede de drenagem. Porém, para a nascente ser considerada ideal, ela deve fornecer água de boa qualidade de maneira abundante e contínua, com boa distribuição no tempo e onde a variação da vazão tenha um mínimo adequado ao longo do ano (Calheiros et al., 2009).

A área de preservação permanente (APP), que se constitui em área protegida com a função ambiental de preservar a estabilidade geológica, a paisagem, a biodiversidade, facilitar o fluxo gênico de fauna e flora, proteger o solo e assegurar o bem-estar das populações humanas, são também indispensáveis na preservação dos recursos hídricos (Brasil, 2012). Devido a essa tamanha importância, sua preservação é prevista na Lei federal $n^{\circ}$. 12.651/12 (Código Florestal), segundo a qual as áreas ao redor das nascentes, num raio mínimo de 50 metros, devem ser ocupadas por vegetação nativa e mantidas preservadas.

As unidades de conservação (UC), tanto as de proteção integral quanto as de uso sustentável, apresentam, como um de seus objetivos, a proteção dos recursos hídricos indo ao encontro dessa necessidade de preservar não só esses recursos, como também as áreas com vegetação nativa em toda a bacia (Brasil, 2000).

Um subsídio importante à gestão das bacias é a identificação dos impactos negativos presentes, pois dependendo do impacto, formas ou alternativas diferentes de manejo deverão ser implantadas visando à melhoria do ambiente. Situações, por exemplo, em que há impactos relacionados à poluição sanitária promoverão alterações da qualidade da água, enquanto que impermeabilização e/ou compactação do solo acarretam uma diminuição da infiltração de água no solo. A ausência de proteção ao redor das nascentes também pode facilitar o fluxo de pessoas e animais, ocasionando o pisoteio e por consequência, alteração na vazão das nascentes.

A avaliação macroscópica das nascentes, considerada por Felippe e Magalhães Junior (2012) uma metodologia simples, prática, didática e com resultados satisfatórios, tem o objetivo de verificar de forma qualitativa e visual o grau de conservação em que as nascentes se encontram a partir da identificação dos impactos ambientais negativos presentes, para que possam ser mitigados.

Os resultados gerados neste estudo são informações importantes ao plano de manejo da Flona de Capão Bonito, principal instrumento de gestão das áreas protegidas, mas que infelizmente encontra-se obsoleto e necessitando de revisão.

Dessa forma, este trabalho teve por objetivo a caracterização das nascentes da bacia do córrego Itanguá, quanto ao tipo e grau de conservação, assim como a identificação de 
impactos ambientais negativos presentes de modo a subsidiar ações que proporcionem a conservação da água na Floresta Nacional de Capão Bonito, SP, Brasil.

\section{MATERIAL E MÉTODOS}

\section{1. Área de estudo}

A bacia do córrego Itanguá está localizada no município de Capão Bonito, estado de São Paulo, Brasil, entre as coordenadas $23^{\circ} 54^{\prime}$ e $23^{\circ} 59^{\prime} \mathrm{S}$; $48^{\circ} 30^{\prime}$ e $48^{\circ} 32^{\prime} \mathrm{W}$. Grande parte de sua área está inserida na Floresta Nacional de Capão Bonito, localizada entre as latitudes $23^{\circ} 50^{\prime}$ e $24^{\circ} 00^{\prime} \mathrm{S}$ e longitude $48^{\circ} 20^{\prime}$ e $48^{\circ} 40^{\prime} \mathrm{O}$, entre os municípios de Capão Bonito e Buri, região do Vale da Serra do Paranapiacaba, sudoeste do estado (Figura 1).

Sua vegetação é composta por Floresta Ombrófila Densa e Savana (SOS Mata Atlântica; INPE, 2012). A altitude média é de 700 metros, com relevo levemente ondulado e o clima da região é caracterizado como Cwa segundo a classificação de Koeppen e precipitação média anual de $1200 \mathrm{~mm}$ (Cepagri, 2015).

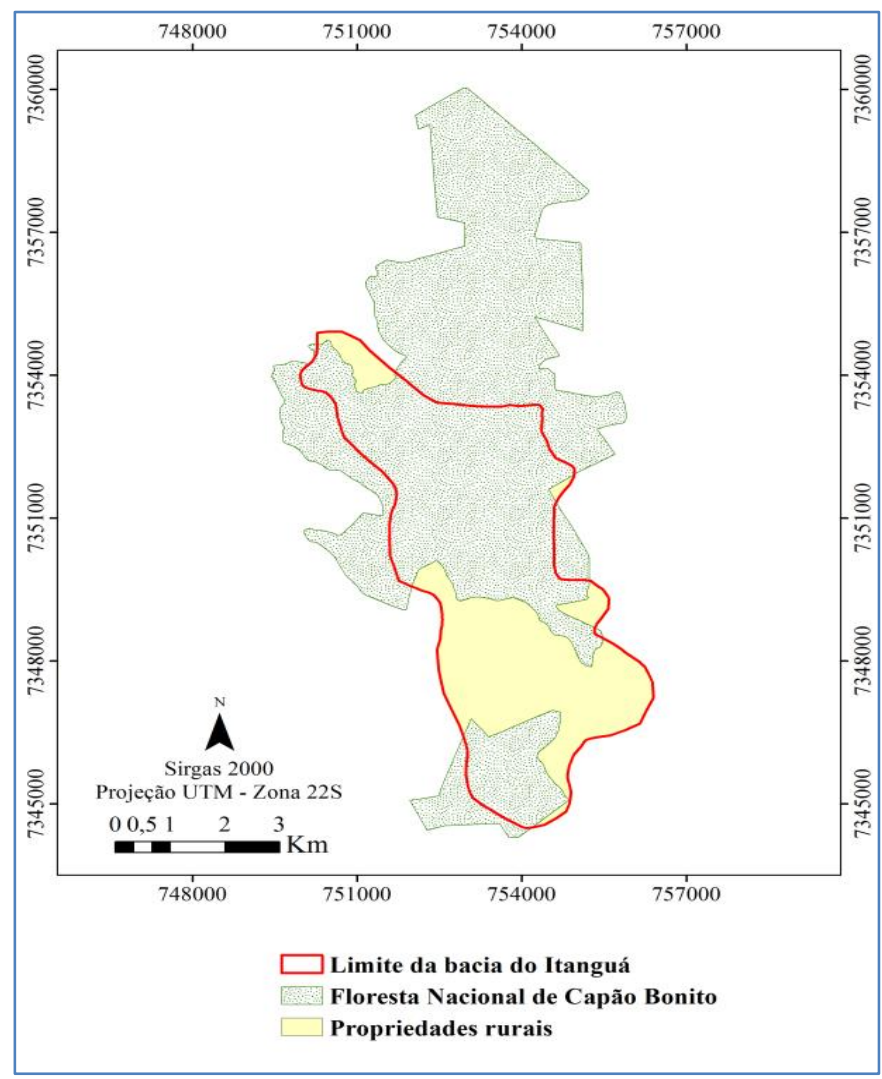

Figura 1. Localização da Floresta Nacional de Capão Bonito e da bacia do Itanguá, Capão Bonito, SP, Brasil.

A Flona de Capão Bonito possui mais de $50 \%$ de seu território ocupado por plantios de Pinus spp., com idade aproximada de 50 anos. Dos 4.344 hectares de área, 3.489,39 ha são ocupados por reflorestamentos, distribuídos em: 2.402,19 ha de Pinus elliotti; 39,47 ha de Pinus spp.; 1.002,00 ha de Araucaria angustifolia; 45,73 ha de experimentos com várias outras espécies florestais nativas e exóticas e outros 270 ha de mata nativa. A área restante é ocupada por aceiros, estradas, espaço para edificações e áreas de lazer (Brasil, 2015). A Flona está dividida em duas glebas, e $40 \%$ de sua área total está inserida na bacia do córrego Itanguá. 


\subsection{Caracterização das nascentes quanto ao tipo}

A bacia foi visitada durante os meses de dezembro/2014 a fevereiro/2015, contemplando assim a estação chuvosa. As nascentes foram georreferenciadas com um receptor GPS de navegação Garmin eTrex Vista e analisadas in loco. A espacialização e análise das informações, tanto as coletadas em campo quanto as obtidas nas cartas topográficas de Buri (SF-22-Z-D-V-4) e Itanguá (SF-22-Z-D-VI-3) do Instituto Brasileiro de Geografia e Estatística (IBGE), foram realizadas no programa QGIS 2.8 e ArcMap 10.1.

As nascentes foram então classificadas quanto ao seu tipo, podendo ser pontual quando apresentava um fluxo d'água em um único ponto do terreno, ou difusa quando havia fluxo d'água em vários pontos (Castro, 2007). A classificação quanto à persistência de fluxo e a quantificação da vazão das nascentes não puderam ser realizadas devido à ausência de quantidade de água necessária para tais aferições.

\subsection{Avaliação macroscópica}

Para a identificação dos impactos ambientais das nascentes da bacia, qualitativamente, foi realizada uma avaliação macroscópica, onde os parâmetros foram adaptados de acordo com as necessidades presentes neste trabalho, tendo como base as metodologias propostas por Gomes et al. (2005) e Felippe e Magalhães Junior (2012). Estes autores usaram como base o Guia de Avaliação da Qualidade das Águas (2004) e a Classificação do grau de impacto da nascente (2004).

A avaliação utilizou os parâmetros especificados na Tabela 1, os quais foram classificados em bom, médio e ruim a partir da atribuição de um valor de um a três, de acordo com a qualificação que cada um recebeu. Assim, a pontuação varia de 11 pontos - quando todos os parâmetros são considerados ruins - a 33 pontos - no caso de todos os parâmetros serem bons.

Tabela 1. Parâmetros utilizados na avaliação macroscópica de nascentes.

\begin{tabular}{lccc}
\hline \multirow{2}{*}{ Parâmetro } & \multicolumn{3}{c}{ Qualificação } \\
\cline { 2 - 4 } & Ruim (1 ponto) & Médio (2 pontos) & Bom (3 pontos) \\
\hline Lixo & Muito & Pouco & Ausente \\
Materiais flutuantes & Muito & Pouco & Ausente \\
Espumas & Muito & Pouco & Ausente \\
Óleos & Muito & Pouco & Ausente \\
Esgoto & Presença & Evidências & Ausente \\
Vegetação na APP & Ausente & Exótica & Nativa \\
Uso pela fauna & Presença & Evidências & Ausente \\
Uso antrópico & Presença & Evidências & Ausente \\
Proteção (cerca) & Ausente & Presente, mas com & Presente, mas com \\
Áreas construídas & Menos de 50 metros & Entre 50 e 100 metros & Acima de 100 metros \\
Tipo da área de & Informação ausente & Propriedade privada & Área protegida \\
inserção &
\end{tabular}

Fonte: Adaptada de Gomes et al. (2005) e Felippe e Magalhães Junior (2012).

Após a contabilização (soma) dos pontos da avaliação, as nascentes foram classificadas quanto ao grau de conservação em relação aos impactos presentes: Classe A (ótimo - 31 a 33 pontos), Classe B (bom - 28 a 30 pontos), Classe C (razoável - 25 a 27 pontos) e Classe E (péssimo - abaixo de 22 pontos) (Gomes et al., 2005; Felippe e Magalhães Junior, 2012). 


\section{RESULTADOS E DISCUSSÃO}

\subsection{Caracterização das nascentes quanto ao tipo}

$\mathrm{Na}$ bacia do Itanguá foram identificadas 19 nascentes, sendo 12 localizadas dentro da Floresta Nacional de Capão Bonito e as demais nas propriedades rurais do entorno. Do total, três não constam nas cartas topográficas utilizadas, mas foram visualizadas em campo $(6,8 \mathrm{e}$ 9).

Quatro nascentes não puderam ser visitadas em decorrência da dificuldade de acesso ao local, portanto somente 15 puderam ser avaliadas in loco. Dessas, nove foram classificadas como pontuais enquanto que seis foram difusas (Figura 2a).

\subsection{Avaliação macroscópica}

Nenhuma nascente apresentou pontuação máxima, porém todas apresentaram pontuação superior a 25, não existindo nenhuma nascente com qualificação ruim (D) ou péssima (E). $O$ menor valor (27) foi verificado na nascente 7, enquanto que as nascentes 5 e 6 obtiveram a maior pontuação (31) (Figura 2b).

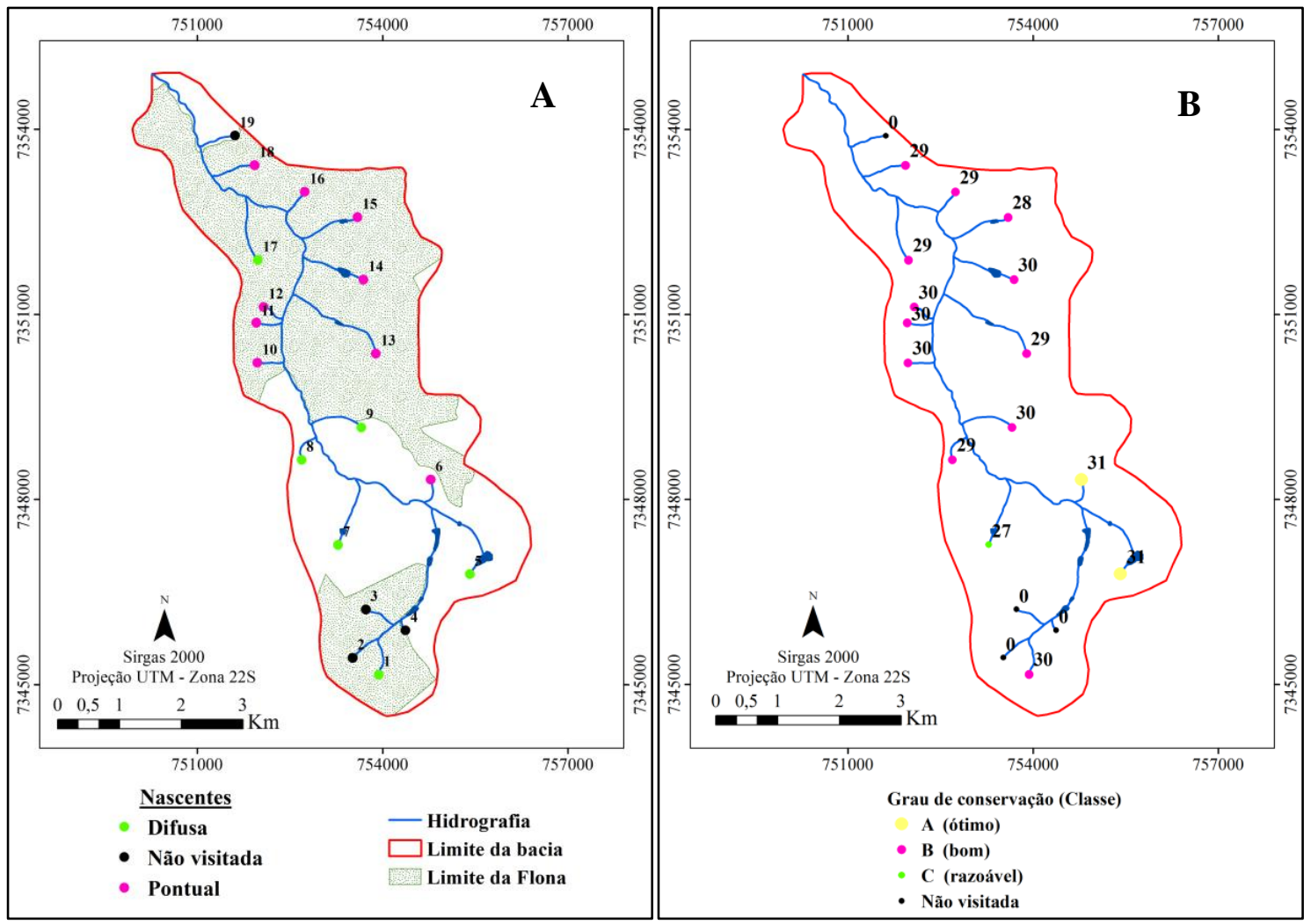

Figura 2. (a) Localização das nascentes da bacia do Itanguá e a classificação quanto ao tipo;

(b) pontuação e grau de conservação das nascentes da bacia do Itanguá.

Todos os parâmetros foram analisados e apresentaram as seguintes considerações:

- Lixo, Materiais flutuantes, Espumas, Óleos, Esgoto: nenhum desses materiais foi encontrado em nenhuma das nascentes avaliadas. Mesmo nas nascentes com fácil acesso não houve nenhum indício de lixo nem de poluição sanitária. Esses resultados indicam menor probabilidade de contaminação, fato este que só pode ser comprovado a partir de uma análise química da qualidade da água.

- Vegetação: 60\% das nascentes apresentaram vegetação exótica (Pinus spp.) predominante na área de preservação permanente, enquanto que em $27 \%$ havia predominância 
de vegetação nativa e somente $13 \%$ estavam com solo descoberto.

- Uso pela fauna e antrópico: em 46,7\% das nascentes foi constatado o uso por animais. Em seis delas havia evidência de uso por Javali, espécie facilmente encontrada na região e que vem causando vários impactos no ambiente. Nas demais nascentes, havia evidência de pisoteio pelo gado, contudo não foi encontrado nenhum animal no momento da avaliação. Esse uso pelos animais pode acarretar em contaminação da água por fezes e urina. Todas as nascentes com presença de pegadas de javali estão localizadas dentro da Flona. Verificou-se também o uso antrópico em apenas uma nascente relacionado ao uso por animais, já que a evidência encontrada foi a presença de ceva na nascente, local apreciado pelo javali.

- Proteção: a proteção da área com cercas é uma prática importante em termos de conservação da área, pois pode impedir o acesso às nascentes, tanto de animais quanto de pessoas, evitando assim que a degradação ocorra. Todas as nascentes que se encontravam dentro da área da unidade de conservação não apresentavam cerca ao redor, mas já se encontram em uma área protegida por lei.

- Áreas construídas: quanto mais próximas as nascentes estão das áreas edificadas, maior a probabilidade de impactos antrópicos. No entanto nenhuma nascente apresentou construções a menos de 100 metros de distância, fato corroborado pela ausência de lixo, esgoto, óleos e materiais flutuantes nas nascentes.

- Tipo da área de inserção: 66\% das nascentes avaliadas se encontram dentro da área da unidade de conservação.

A partir da análise dos dados pôde-se perceber, portanto, que os maiores impactos encontrados nas áreas das nascentes foram a presença de espécies exóticas, tanto animal, a qual pode provocar a contaminação da água (fezes e urina), pisoteio e revolvimento do solo, quanto a vegetal, por ocupar as áreas de preservação permanente destinadas à vegetação nativa e, assim, poder alterar o ciclo hidrológico e a regeneração natural no sub-bosque.

Os javalis (Sus scrofa) e os "javaporcos" (híbridos férteis) são altamente competitivos com as espécies nativas, pois são espécies agressivas e resistentes sem predadores naturais, impactando o ambiente por onde passam, revolvendo o solo, destruindo a vegetação nativa devido ao pisoteio e alimentação, e provocando até mesmo a desestruturação do solo, podendo desencadear processos erosivos e de assoreamento dos corpos d'água, sem contar os prejuízos econômicos das lavouras (Massei e Genov, 2004).

No mundo todo é possível encontrar casos de distúrbios provocados pelos javalis. Mitchell (2011) verificou significantes impactos na qualidade da água em áreas tropicais alagadas na Austrália. Em um estudo realizado na Nova Zelândia foi identificada a perturbação direta pelos suínos selvagens através da retirada de plantas, e indiretamente pelo aumento de nitrato, provocando alterações no ambiente (Krull et al., 2013).

No Brasil a presença de grupos de javalis asselvajados já foi registrada em vários estados, como Rio Grande do Sul, Santa Catarina, Paraná, São Paulo, Minas Gerais, Mato Grosso do Sul, Mato Grosso, Goiás, Bahia e Acre (IBAMA, 2015). Segundo os anexos do $1^{\circ}$ Relatório do grupo técnico sobre espécies exóticas com potencial de invasão, o município de Capão Bonito está na lista dos 64 municípios com registro de javali no estado de São Paulo (São Paulo, 2013).

Em um estudo realizado na região sul do Brasil, os resultados mostraram a preferência da espécie por áreas naturais preservadas, representando uma grande ameaça para as florestas e áreas protegidas dessa região. Os autores também sugerem mais estudos quanto ao impacto da espécie sobre os ambientes naturais, principalmente o impacto provocado pela predação de sementes de Araucária (Araucaria angustifolia), espécie arbórea presente na Flona e que 
acaba se comportando como fornecedora de alimento e facilitando assim a presença dos animais no local (Hegel e Marini, 2013).

Esses animais têm atraído a atenção de governos e pesquisadores por ser considerada uma das piores espécies exóticas invasoras (Lowe et al., 2000). No Brasil, em razão do crescimento populacional e dispersão sem controle dos javalis em todo o país, a Instrução Normativa $\mathrm{n}^{\circ} .03$ (Brasil, 2013) autoriza o controle populacional do javali que vive em liberdade em todo o território nacional. Outro tipo de controle apontado em estudos é a colocação de cercas, que pode ajudar, dependendo de cada caso (Mitchell, 2011).

Para o controle do javali, a caça na região da Flona já tem ocorrido e, segundo funcionários e moradores da região, o avistamento desses animais já diminuiu. A construção de cercas ao redor das nascentes evitaria o acesso desses e de até mesmo outras espécies animais, evitando degradação.

O gênero Pinus spp. foi introduzido na UC para a realização de experimentos devido à política de reflorestamento em larga escala que estava sendo incentivada no país na década de 60, restando uma grande quantidade de talhões em pé até hoje.

Como a Flona é uma UC de uso sustentável, o plantio de espécies exóticas como o Pinus é permitido, porém elas não devem estar presentes nas áreas de preservação permanente, margeando os cursos d'água e as nascentes (Brasil, 2012).

O Pinus, além de ser exótico, é também considerado uma espécie invasora em ambientes naturais, pois apresenta elevado consumo de água quando plantado de maneira adensada, além de poder impedir a regeneração natural. Porém, ele também pode promover benefícios em determinadas circunstâncias atuando como facilitador, como pode ser visto em alguns casos citados a seguir.

Onaindia et al. (2013) verificou que a regeneração natural no sub-bosque de um plantio antigo de Pinus radiata, espécie exótica, no Norte da Península Ibérica apresentou composição pouco semelhante à floresta nativa, sendo necessário algum manejo para o avanço do processo sucessional.

No Brasil, em um estudo realizado em uma região de Cerrado, no município de Assis, SP, Durigan et al. (2014) perceberam que o plantio de Pinus elliottii, independente do espaçamento, acelerou cerca de quatro vezes a cobertura do terreno em relação à área testemunha sem plantio. Porém, a densidade de plantas em regeneração tem sido menor nos últimos anos, indicando que a remoção gradual dos indivíduos poderia ser favorável. No entanto, os autores advertem que são necessários mais estudos a longo prazo em relação à competição da espécie exótica com as nativas, sendo insuficiente os seis anos de observação.

Em um estudo já realizado na Flona de Capão Bonito pôde-se verificar a presença de indivíduos regenerantes (CAP $\geq 15 \mathrm{~cm}$ ) sob plantios de Pinus elliottii distribuídos em 38 espécies e 20 famílias, numa densidade de 600 ind/ha (Tonello, 2013), enquanto que em outros talhões é possível perceber a ausência de regeneração natural no sub-bosque.

O Pinus também pode influenciar, além da vegetação, a dinâmica hídrica da bacia. Em um estudo realizado por Swank e Douglas (1975), eles verificaram uma diminuição na produção de água de aproximadamente $94 \mathrm{~mm}$ em uma floresta plantada de Pinus strobus, com idade de 10 anos em relação à floresta natural.

Em uma bacia da África do Sul, onde a vegetação natural foi substituída por Eucalyptus grandis e Pinus patula, foi observada uma redução de $30 \%$ no deflúvio a partir do terceiro ano de implantação (Scott e Lesch, 1997). No entanto, Lima e Freire (1976) ao estudarem áreas com eucalipto, pinheiros e vegetação herbácea natural, situadas à margem do Córrego Monte Olimpo em Piracicaba, SP, não detectaram nenhuma consequência adversa sobre o regime da água do solo como consequência do reflorestamento.

Dessa forma, os resultados aqui apresentados podem subsidiar a gestão ambiental da Flona e do entorno, podendo ser voltada, principalmente, para a substituição das espécies 
exóticas florestais por espécies nativas nas áreas de mata ciliar. No entanto, o manejo dessas espécies deve ser planejado de acordo com o comportamento das mesmas no local, ou seja, é importante observar se ela está atuando como facilitadora ou não, já que as duas situações podem ser encontradas no local.

A colheita florestal, atividade que inicia esse processo de substituição de espécies, pode acarretar em significativos impactos negativos na bacia hidrográfica, como a alteração do balanço hídrico, da vazão e da concentração de nutrientes na água, como pode ser visto no estudo realizado por Oki (2002), onde a autora verificou um aumento na concentração de sedimentos na água devido ao maior escoamento superficial após o corte raso de uma floresta de Pinus. Por isso a exploração deve ser bem planejada em áreas com maiores declives e próximas aos cursos d'agua, como as de matas ciliares, para minimizar os impactos.

Nas áreas em que a substituição do pinus não é exigida pela lei, o manejo deve ser adequado, realizando-se desbastes, por exemplo. Já foi verificado que após a realização de um desbaste leve em povoamentos de Pinus sp., houve a redução do consumo de água em $75 \%$ em comparação com uma floresta não desbastada (Lima, 1979). No entanto esses valores podem variar de acordo com as características de cada local. No caso das nascentes que se encontram sem vegetação ou com outros tipos de uso, é necessário que elas sejam restauradas por meio de plantio de espécies nativas.

\section{CONCLUSÃO}

Das nascentes analisadas in loco, $60 \%$ foram caracterizadas como pontuais, enquanto que as demais foram difusas e, de acordo com a avaliação macroscópica, 13\% das nascentes foram consideradas com ótimo, $80 \%$ com bom e $7 \%$ com razoável estado de conservação.

Os principais impactos ambientais negativos observados foram a presença de espécies exóticas, tanto animal como vegetal: Javali (Sus scrofa) e Pinus spp., e a ausência de vegetação nativa na área de preservação permanente dos cursos d'água.

A metodologia empregada foi considerada de fácil entendimento e utilização, apesar da avaliação de alguns parâmetros, como lixo, materiais flutuantes, espumas e óleos não fazer uso de valores numéricos para quantificá-los, visto que são difíceis de serem mensurados devido a uma grande variação de região para região. Ainda assim, se mostrou eficiente como uma análise qualitativa visual da situação das nascentes e como fornecedora de informações importantes no direcionamento do manejo a ser seguido para o controle dos impactos ambientais negativos. Esse tipo de conhecimento se constitui em importante etapa da gestão e planejamento de bacias hidrográficas.

\section{AGRADECIMENTOS}

À Coordenação de Aperfeiçoamento de Pessoal de Nível Superior (CAPES), pela bolsa de mestrado da primeira autora.

\section{REFERÊNCIAS}

BRASIL. Lei federal $n^{\circ} 9.985$, de 18 de julho de 2000, regulamenta o art. 225, §1o, incisos I, II, III e VII da Constituição Federal, institui o Sistema Nacional de Unidades de Conservação da Natureza (SNUC) e dá outras providências. Diário Oficial [da] União, Brasília, 19 jul. 2000. 
BRASIL. Lei federal $n^{\circ}$. 12.651, de 25 de maio de 2012, dispõe sobre a proteção da vegetação nativa; altera as Leis $\mathrm{n}^{\mathrm{os}} 6.938$, de 31 de agosto de 1981, 9.393, de 19 de dezembro de 1996, e 11.428, de 22 de dezembro de 2006; revoga as Leis $\mathrm{n}^{\mathrm{os}} 4.771$, de 15 de setembro de 1965, e 7.754, de 14 de abril de 1989, e a Medida Provisória n-2.166-67, de 24 de agosto de 2001; e dá outras providências. Diário Oficial [da] União, Brasília, 28 maio 2012.

BRASIL. Ministério do Meio Ambiente. Secretaria de Biodiversidade e Florestas. Departamento de Áreas Protegidas. Cadastro nacional de unidades de conservação CNUC. Unidade de conservação: Floresta nacional de Capão Bonito. Disponível: https://goo.gl/PMgYkG. Acesso em: 03 jun. 2015.

CALHEIROS, R. O. et al. Cadernos da Mata Ciliar n. 1: preservação e recuperação das nascentes, de água e vida. São Paulo: SMA, 2009. 35 p.

CASTRO, P. S. Recuperação e conservação de nascentes. Viçosa, MG: CPT, 2007. 272 p.

CENTRO DE PESQUISAS METEREOLÓGICAS E CLIMÁTICAS APLICADAS A AGRICULTURA - CEPAGRI. Clima dos municípios paulistas: Capão Bonito. Disponível em: https://goo.gl/FXXbQM. Acesso em: 03 jun. 2015.

DURIGAN, G.; CONTIERI, W. A.; MELO, A. C. G.; GARRIDO, M. A. O. Regeneração da mata ciliar sob plantio de Pinus elliotti var. elliotti em diferentes densidades. In: VILAS BÔAS, O.; DURIGAN, G. Pesquisas em conservação e recuperação ambiental no oeste paulista. São Paulo: Instituto Florestal, 2014. Disponível em: https://goo.gl/LJTD5A. Acesso em: 25 jun. 2015.

FELIPPE, M. F.; MAGALHÃES JUNIOR, A. P. Impactos ambientais macroscópicos e qualidade das águas em nascentes de parques municipais em Belo Horizonte - MG. Geografias, v. 8, n. 2, p. 8-23, 2012.

GOMES, P. M.; MELO, C.; VALE, V. S. Avaliação dos impactos ambientais em nascentes na cidade de Uberlândia-MG: análise macroscópica. Sociedade \& Natureza, v. 17, n. 32, p. 103-120, 2005.

HEGEL, C. G. Z.; MARINI, M. A. Impacto do javali europeu, Sus scrofa, em um fragmento da Mata Atlântica brasileira. Neotropical Biology and Conservation, v. 8, n. 1, p. 1724, 2013. http://dx.doi.org/10.4013/nbc.2013.81.03

INSTITUTO BRASILEIRO DO MEIO AMBIENTE E DOS RECURSOS NATURAIS RENOVÁVEIS - IBAMA. Instrução normativa $n^{\circ}$. 03, de 31 de janeiro de 2013. Decreta a nocividade do Javali e dispõe sobre o seu manejo e controle. Diário Oficial [da] União, Brasília, 01 fev. 2013, Seção 1, p. 88-89.

INSTITUTO BRASILEIRO DO MEIO AMBIENTE E DOS RECURSOS NATURAIS RENOVÁVEIS - IBAMA. O javali asselvajado: norma e medidas de controle. Disponível em: https://goo.gl/XcUnXD. Acesso em: 20 jun. 2015.

KRULL, C. R.; CHOQUENOT, D.; BURNS, B. R.; STANLEY, M. C. Feral pigs in a temperate rainforest ecosystem: disturbance and ecological impacts. Biological Invasions, v. 15, p. 2193-2204, 2013. http://dx.doi.org/10.1007/s10530-013-0444-9

LIMA, W.P. A água do solo e o crescimento da floresta. Piracicaba: IPEF, 1979. (Circular técnica, 59). 
LIMA, W. P.; FREIRE, O. Evapotranspiração em plantações de eucalipto e de pinheiro e em vegetação herbácea natural. IPEF, v. 13, p. 75-90, 1976.

LOWE, S.; BROWNE, M.; BOUDJELAS, S.; DEPOORTER, M. 100 of the World's worst invasive Alien species: a selection from the global invasive species database. Auckland: ISSG, 2000. 12 p.

MASSEI, G.; GENOV, P.V. The environmental impact of wild boar. Galemys, v. 16, n. especial, p. 135-145, 2004.

MITCHELL, J. Ecological impacts of feral pigs (Sus scrofa) on freshwater ecosystems in tropical Australia. In: EUROPEAN VERTEBRATE PEST MANAGEMENT CONFERENCE, 8., 26-30 set. 2011, Berlin. Julius-Kühn-Archiv, n. 432, 2011.

ONAINDIA, M.; AMETZAGA-ARREGI, I.; SAN SEBASTIAN, M.; MITXELENA, A.; RODRIGUEZ-LOINAZ, G.; PEÑA, L. et al. Can understorey native woodland plant species regenerate under exotic pine plantations using natural succession? Forest Ecology and Management, v. 308, p. 136-144, 2013. http://dx.doi.org/10.1016/j.foreco.2013.07.046

OKI, V. K. Impactos da colheita de Pinus taeda sobre o balanço hídrico, a qualidade da água e a ciclagem de nutrientes em microbacias. 2002. $71 \mathrm{f}$. Dissertação (Mestrado em Ciências Florestais) - Escola Superior de Agricultura Luiz de Queiroz, Universidade de São Paulo, Piracicaba, 2002.

SÃO PAULO (Estado). Secretaria do Meio Ambiente. Coordenadoria de Biodiversidade e Recursos Naturais. Anexos do $\mathbf{1}^{\mathbf{0}}$ relatório do grupo técnico sobre espécies exóticas com potencial de invasão. Dez. 2013. Disponível em: https://goo.gl/7n0RTd. Acesso em: 20 jun. 2015.

SCOTT, D. F.; LESCH, W. Streamflow responses to afforestation with Eucalyptus grandis and Pinus patula and to felling in the Mokobulaan experimental catchments, South África. Journal of Hydrology, v. 199, n. 3/4, p. 360-377, 1997. http://dx.doi.org/10.1016/S0022-1694(96)03336-7

SOS MATA ATLÂNTICA; INSTITUTO DE PESQUISAS ESPACIAIS - INPE. Atlas dos remanescentes da mata Atlântica. 2012. Disponível em: http://mapas.sosma.org.br/. Acesso em: 16 abr. 2015.

SWANK, W. T.; DOUGLAS, J. E. Conversion of hardwood-covered watershed to White Pine reduces water yield. Water Resources Research, v. 4, p. 947-954, 1975. http://dx.doi.org/10.1029/WR004i005p00947

TONELLO, K. C. Avaliação da regeneração natural em sub-bosque de plantios de Pinus elliottii Engelm. e Araucaria angustifolia (Bertol.) Kuntze em Capão Bonito - SP. 2013. 23 f. Iniciação Científica (Graduando em Engenharia Ambiental) - Universidade Federal de São Carlos, Sorocaba, 2013. 


\begin{tabular}{|} 
Ambiente \& Água - An Interdisciplinary Journal of Applied Science \\
ISSN 1980-993X - doi:10.4136/1980-993X \\
www.ambi-agua.net \\
E-mail: ambi.agua@gmail.com
\end{tabular}

\title{
Monitoramento da água de poços como estratégia de avaliação sanitária em Comunidade Rural na Cidade de São Luís, MA, Brasil
}

\author{
doi:10.4136/ambi-agua.1962
}

Received: 30 Jun. 2016; Accepted: 01 Dec. 2016

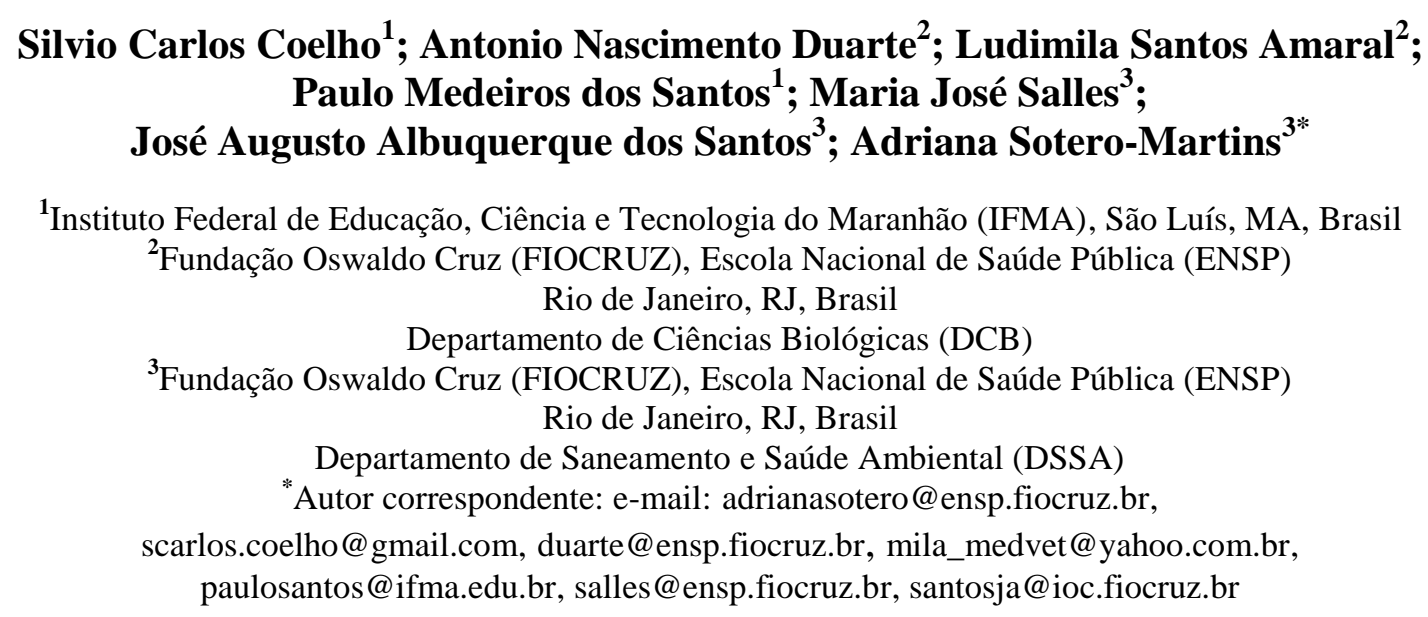

\section{RESUMO}

Como ações de saneamento são escassas ou inexistentes no meio rural, o monitoramento das fontes de água permite o diagnóstico dos riscos e da precariedade das situações de saneamento. Neste estudo foi monitorado sazonalmente a qualidade da água dos poços da comunidade rural "Cinturão Verde" por meio de análises físico-químicas, colimétricas, e parasitológicas para identificação de fontes de contaminação devido à ausência de meios adequados de saneamento. Foram analisadas amostras coletadas em quatro períodos sazonais e detectados coliformes acima dos padrões de potabilidade do Ministério da Saúde nos poços tubulares em três dos quatro períodos sazonais. Foi detectada também a presença de parasita no período seco. Os parâmetros físico-químicos também estavam fora dos padrões da legislação em algumas estações, e foi constatado que esses riscos eram devido à inexistência de serviços de saneamento como: abastecimento com poços sem tratamento, precariedade de esgotamento e proximidade dos mananciais à criação de animais. Conclui-se que o monitoramento permitiu detectar períodos de riscos no uso de águas dos poços, avaliar diferenças regionais, e a necessidade de medidas de desinfecção da água antes de ser utilizada. Estas medidas de saneamento rural podem garantir a proteção dos mananciais de águas subterrâneas.

Palavras-chave:águas subterrâneas, qualidade sanitária, saneamento, saúde ambiental.

\section{The monitoring of water wells as health evaluation strategy in Rural Community in São Luís City, MA, Brazil}

\begin{abstract}
As sanitation is scarce or nonexistent in a rural environment, the monitoring of water sources allows for the diagnosis of risks and precarious sanitation situations. This study
\end{abstract}


seasonally monitored the water quality of wells in the rural community of Cinturão Verde by means of physical and chemical analysis and colimetric and parasitological assays, and identified sources of contamination due to the lack of adequate sanitation. Samples collected in four seasonal periods detected levels of coliform in wells above the potability standards of the Health Ministry in three of the periods, and detected the presence of parasites in the dry season. Physical and chemical parameters also exceeded legal standards in some periods, and it was found that these risks were due to lack of proper sanitation practices, such as water supplied by untreated wells, improper drainage and the proximity of water sources to livestock. Water monitoring enabled the detection of risk periods when using well waters, the evaluation of regional differences, and the showed the need for water disinfection before use. These rural sanitation measures can help to ensure the protection of groundwater sources.

Keywords: groundwater, environmental health, sanitation, sanitary quality.

\section{INTRODUÇÃO}

A interface do saneamento com a qualidade de vida e a saúde pressupõe um ambiente saudável. Ações inerentes ao saneamento são pouco intensas no meio rural, geralmente composto somente pelo abastecimento de água (nem sempre potável) coleta e disposição final dos resíduos sólidos e sistema de esgotamento sanitário precário. Como esses fatores atuam promovendo a salubridade ambiental, no meio rural os riscos relacionados à precariedade do saneamento são mais evidentes (Daniel, 2001; Amaral et al., 2003; Costa e Guilhoto, 2014). Em locais com saneamento básico deficiente, as doenças de veiculação hídrica podem ocorrer devido à contaminação da água por dejetos ou pelo contato com esgoto despejado nas ruas ou nos córregos e rios. A falta de água também pode causar doenças, pois a escassez impede a higiene adequada. E ainda inclui-se a proliferação de insetos que se desenvolvem na água (CVE, 2009). As principais doenças relacionadas à ineficiência e/ou inexistência dos serviços de saneamento são causadas principalmente por microrganismos patogênicos de origem entérica, animal ou humana (Amaral et al., 2003).

O acesso à água potável tem impacto no desenvolvimento socioeconômico, e segundo a Organização das Nações Unidas (ONU) é um direito humano essencial, intrinsicamente relacionado com o direito à vida, à saúde e à alimentação. Há evidências de que o gasto com medidas de saneamento é mais eficaz do que os gastos com saúde, principalmente em relação ao acesso a água de qualidade e tratamento de esgoto. Os investimentos em saneamento acarretam a diminuição de casos de morbidade e de internações hospitalares (Caldeira, 2014). Portanto, cabe ao Estado a responsabilidade de assegurar esse direito a todos os cidadãos, sobretudo aqueles em situação de vulnerabilidade socioambiental, como a população da zona rural (Heller e Pádua, 2006). Portanto o saneamento é um instrumento de promoção e de melhoria da saúde, como determinado pela Lei de Saneamento No. 11.445/2007. Essa Lei estabelece um conjunto de serviços, infraestrutura e instalações operacionais de abastecimento de água potável, esgotamento sanitário, manejo de resíduos sólidos, drenagem e manejo de águas pluviais urbanas (Brasil, 2010).

Ações adequadas de saneamento rural promovem a salubridade ambiental e contribuem para diminuição da degradação do ambiente e da exploração de forma insustentável dos recursos naturais. Para isso, medidas planejadas, em especial as que garantam a proteção dos mananciais de água doce, com a disposição adequada do esgotamento sanitário e dos resíduos sólidos são fundamentais (Costa e Guilhoto, 2014; Brasil, 2006).

A qualidade da água no ambiente é função do uso e da ocupação do solo na bacia hidrográfica onde o manancial se encontra. Essa qualidade é influenciada pelos seguintes fatores: condições naturais, que podem afetar o escoamento superficial; infiltração no solo, 
resultantes da precipitação atmosférica; atuação do homem, interferindo com a geração de despejos domésticos, industriais, e de criação de animais; e a aplicação de defensivos agrícolas no solo, que de diversas formas contribui com a introdução de compostos na água. Esses fenômenos de poluição apresentam riscos à saúde e comprometem um ou mais usos dos mananciais com a perda de qualidade devido a alterações em suas características (Brasil, 2006).

A identificação dos microorganismos patogênicos na água é geralmente complexa e onerosa. Por essa razão, tradicionalmente se recorre à identificação de organismos indicadores de contaminação, como por exemplo, organismos cuja presença apontaria a introdução de material de origem fecal (humana ou animal) na água, e, portanto, o risco potencial da presença dos organismos patogênicos. Os bioindicadores tradicionais para esse fim são as bactérias do grupo coliforme (coliformes totais e coliformes termotolerantes) e a espécie de bactéria Escherichia coli (Sotero-Martins et al., 2013). As águas subterrâneas apresentam menos restrição de uso in natura em relação às águas superficiais, pois as camadas do solo servem como filtros naturais eliminando contaminantes (Herráiz, 2009). Contudo, para fins de abastecimento humano, a água precisa passar por um processo de desinfecção, como preconiza a Portaria do Ministério da Saúde (MS) No. 2.914/2011, que estabelece os padrões de potabilidade e também define os teores toleráveis de certas impurezas, e a Resolução do CONAMA No. 368 de 3 de abril de 2008 que trata sobre o uso de águas subterrâneas (Hager, 2007).

Devido aos riscos associados ao consumo de água contaminada, é indispensável o tratamento da água para consumo humano e uso na agricultura, que tem por finalidade inicial, torná-la potável. Portanto, os principais objetivos do tratamento são de ordem sanitária (remoção e inativação de organismos patogênicos e de substâncias químicas que apresentam risco a saúde) e estética organoléptica (remoção de turbidez, cor, sabor e odor) (Brasil, 2006). Os métodos que podem ser empregados no tratamento da água com objetivo da desinfecção que não é a eliminação total dos microrganismos, mas sim diminuir a população de patógenos (Gonçalves et al., 2003) - são os métodos químicos, biológicos, físicos e/ou fotoquímicos (Tchobanoglous et al., 2003; Archer et al., 1997; Von Sperling et al., 2003). A principal forma de desinfecção química utilizada é a cloração, que é um processo químico que utiliza o cloro (Aisse et al., 2003). Contudo, o método físico altamente recomendado para áreas desprovidas de recursos é a fervura da água para beber, quando a sua qualidade não merece confiança e em épocas de surtos epidêmicos ou de emergência. Para minimizar o sabor desagradável que fica após o processo, deve-se agitar a água para que o ar penetre em sua massa (Medeiros Filho, 2009).

Neste sentido, o objetivo deste trabalho foi realizar o monitoramento sazonal da qualidade da água de poços tubulares da comunidade rural "Cinturão verde" de São Luís MA, e identificar prováveis fontes de contaminação do solo e da água subterrânea, decorrentes da ausência de meios adequados de saneamento.

\section{MATERIAL E MÉTODOS}

O estudo foi do tipo descritivo e exploratório, com coleta de amostras de água nos poços tubulares, realizadas em quatro regiões da Comunidade Cinturão Verde, localizada na área rural a sudoeste da Ilha de São Luís - MA, no município de São Luís, na microbacia do Tibirí, entre as coordenadas 585160 E - 9706768 S; 586475 E - 9708085 S; Sistema de Projeção: UTM SIRGAS 2000 Zona 23 S - datum: D SIRGAS 2000. Esta comunidade tem como principal atividade a produção de hortaliças, legumes e frutas próximo a um aterro sanitário, conta com oitenta domicílios, num total de 342 pessoas. As amostras foram coletadas nos quatro poços artesianos ativos, que possuem cerca de 50 a 60 metros de profundidade, e não 
seguem um padrão de construção. Os períodos sazonais foram definidos de acordo com o balanço hídrico das séries históricas do clima de São Luís - MA do ano de 2013 (Agritempo, 2009), sendo os períodos de transição seco/chuvoso (P-S/C), janeiro; chuvoso (P-C), abril; transição chuvoso/seco (P-C/S), julho; e seco (P-S), outubro. Foi monitorada a qualidade da água quanto aos parâmetros físico-químicos, colimétricos e parasitológicos.

Os locais de coleta foram georeferenciados, e foram registradas as características dos elementos que compõem o saneamento rural. Os quatro poços monitorados foram: P1-1A (região ao norte, possui um abatedouro); P3-8A (região a oeste, possui uma horta); P4-13A (região ao centro, área residencial predominante) e P6-20A (região ao sul, área residencial predominante) - Dois poços estavam inativos (P2 e P5). O tempo de coleta e a realização das análises colimétricas não excederam as 24 horas (APHA, 1998), e não foram necessárias diluições das amostras. Foram considerados como referência os parâmetros de potabilidade estabelecido na Portaria do MS No. 2914/2011 (Brasil, 2011). Os parâmetros analisados foram os físico-químicos: turbidez, cor aparente, condutividade, $\mathrm{pH}$, cloro, sólidos totais, dureza total, alcalinidade, cloretos, salinidade e oxigênio dissolvido; e os parâmetros bacteriológicos para coliformes totais (CT) e Escherichia coli (EC), sendo utilizado o método do substrato cromogênico Colilert ${ }^{\circledR}$ Quanti-Tray 2000 da IDEXX, segundo normas descritas pelo fabricante. Os dados, porém, foram convertidos para Unidade Formadora de Colônia (UFC) por mililitro, baseados nos dados descritos em Gronewold e Wolpert (2008). Para as análises parasitológicas, dois mil litros de água dos poços foram filtradas em refil poroso coberto com manta de estercelulose de $47 \mu \mathrm{m}$ conforme descrito em Handam (2016), para retenção do material particulado. Esses elementos filtrantes foram desfeitos e foram utilizadas as técnicas de Lutz (1919) e de Baermann (1917) adaptadas (Amaral et al., 2015) para análise das três lâminas que foram preparadas para cada amostra e examinados à 100X e 400X de aumento, conforme descrito em Amaral et al. (2015).

\section{RESULTADOS E DISCUSSÃO}

Para o parâmetro físico de avaliação do nível de turbidez, que se deve à presença de material sólido em suspensão, causando um aspecto estético indesejável (APHA, 1998), o valor máximo permitido (VMP) de referência na água de consumo apresentou-se satisfatório em todos os períodos, o que garante a qualidade da água (Tabela 1). Esse parâmetro possui grande relevância devido à dificuldade na desinfecção pela proteção conferida pelas partículas em suspensão, impedindo o contato direto dos agentes patogênicos aos desinfetantes (Brasil, 2011).

A cor aparente da água, que é uma característica associada a substâncias dissolvidas ou em suspensão (Pinto et al., 2015), teve variação média nos quatro períodos sazonais (P-S/C, $\mathrm{P}-\mathrm{C}, \mathrm{P}-\mathrm{C} / \mathrm{S}$ e $\mathrm{P}-\mathrm{S})$ em conformidade com a legislação, sendo que no período de transição seco-chuvoso (P-S/C) e chuvoso-seco (P-C/S) apresentaram-se valores em média de $5,02 \pm 2,02$ e 12,64 $\pm 1,10$, respectivamente (Tabela 1). Este parâmetro, embora não implique risco à saúde, pode provocar rejeição pelo consumidor, e o inconveniente de manchar roupas, vasilhames de alimentos, pias, etc (Brasil, 2011).

Embora a Portaria No. 2.914/2011 não faça referências ao parâmetro físico da condutividade elétrica (CE), Chapman e Kimstach (1996) descreveram que a CE em águas doces varia de 10 a $1000 \mu \mathrm{S} \mathrm{cm}^{-1}$, e indicaram este parâmetro como um indicador da presença de material orgânico recente introduzido nas águas. Quando a condutividade for igual ou superior a $1000 \mu \mathrm{S} \mathrm{cm}^{-1}$, as águas passam a ficar salobras ou podem estar poluídas. Segundo Richards (1954), os limites para a classe de salinidade $\mathrm{C} 1$ ficaria entre $0-250 \mu \mathrm{S} \mathrm{cm}^{-1}$, sendo descrita como água com baixa salinidade, podendo ser utilizada para irrigação nas culturas, em quase todos os tipos de solos. Os valores medidos para CE nas águas dos poços foram 
baixos, com variação média mínima de $130,9 \pm 39,75$ para o período chuvoso (P-C) e máxima de 168,3 \pm 68,29 para o período de transição C/S (P-C/S) (Tabela 1).

$\mathrm{O}$ parâmetro do $\mathrm{pH}$ foi dosado por representar íons hidrogênio $\mathrm{H}^{+}$e dar indicação sobre a condição de acidez, neutralidade ou alcalinidade da água, sendo os valores abaixo de 7 (sete) considerados ácidos, 7 (sete), neutro e acima de 7 (sete). alcalino ou básico. Para fins de consumo humano, a Portaria do MS No. 2914/2011 define os padrões de potabilidade da água, como valor mínimo permitido de 6,0 (seis) e o valor máximo permitido de 9,5 (nove e meio). Valores baixos de $\mathrm{pH}$ podem gerar problemas como: irritação nos olhos, na pele e membranas/mucosas. $\mathrm{O}$ pH baixo ou muito elevado também pode afetar o desempenho do tratamento de desinfecção da água. Nas águas naturais, as variações destes parâmetros são ocasionadas geralmente pelo consumo e/ou produção de dióxido de carbono $\left(\mathrm{CO}_{2}\right)$, realizados por organismos fotossintetizadores e pelos fenômenos de respiração/fermentação de todos os organismos presentes na massa de água, produzindo ácidos orgânicos fracos. Nas amostras monitoradas nos quatros períodos: P-S/C, P-C, P-C/S e P-S a variação media foi de $5,35 \pm 0.51 ; 5,81 \pm 0.60 ; 5,54 \pm 0.56$ e 5,69 \pm 0.87 , respectivamente (Tabela 1), portanto abaixo da faixa recomendada pela legislação, indicando necessidade de tratamento.

As amostras apresentaram ausência de cloro residual livre (CRL), o que pode possibilitar a presença de patógenos na água (Tabela 1). Uma concentração de $0,5 \mathrm{mg} \mathrm{L}^{-1}$ de CRL na água, depois de 30 minutos de contato garante a desinfecção satisfatória. $\mathrm{O}$ teor de cloro ativo que permanece após a desinfecção (cloração) da água, permite que a qualidade microbiológica seja mantida em condições de consumo. Para águas potáveis, segundo o Art. $34^{\circ}$, Portaria do MS No. 2914/2011, é obrigatória a manutenção de no mínimo $0,2 \mathrm{mg} \mathrm{L}^{-1}$ de CLR ou $2 \mathrm{mg} \mathrm{L}^{-1}$ de cloro residual combinado, ou de $0,2 \mathrm{mg} \mathrm{L}^{-1}$ de dióxido de cloro em toda extensão do sistema de distribuição (reservatório ou rede).

Tabela 1. Variação média dos parâmetros físico-químicos dos períodos de transição seco-chuvoso (P-S/C), chuvoso (P-C), transição chuvoso-seco (P-C/S) e seco (P-S).

\begin{tabular}{|c|c|c|c|c|c|}
\hline Parâmetros & $\mathrm{P}-\mathrm{S} / \mathrm{C}$ & P-C & $\mathrm{P}-\mathrm{C} / \mathrm{S}$ & $\mathrm{P}-\mathrm{S}$ & VMP \\
\hline Físicos & $\mathrm{X} \pm \mathrm{DP}$ & $\mathrm{X} \pm \mathrm{DP}$ & $\mathrm{X} \pm \mathrm{DP}$ & $\mathrm{X} \pm \mathrm{DP}$ & \\
\hline Temperatura da água $\left({ }^{\circ} \mathrm{C}\right)$ & $29 \pm 0,33$ & $29 \pm 0,82$ & $29,4 \pm 0,82$ & $29,8 \pm 0,87$ & - \\
\hline Turbidez (NTU) & $0,90 \pm 0,33$ & $0,79 \pm 0,34$ & $0,53 \pm 0,18$ & $0,53 \pm 0,19$ & $5^{(1)}$ \\
\hline Cor Aparente (uH) & $5,02 \pm 2,02$ & $9,65 \pm 2,38$ & $12,64 \pm 1,10$ & $9,17 \pm 4,15$ & $15^{(1)}$ \\
\hline $\begin{array}{l}\text { Condutividade elétrica ( } \mu \mathrm{S} \\
\mathrm{cm}^{-1} \text { ) }\end{array}$ & $148,7 \pm 71,21$ & $130,9 \pm 39,75$ & $168,3 \pm 68,29$ & $163 \pm 78,98$ & ND \\
\hline \multicolumn{6}{|l|}{ Químicos } \\
\hline $\mathrm{pH}$ & $5,35 \pm 0,51$ & $5,81 \pm 0,60$ & $5,54 \pm 0,56$ & $5,69 \pm 0,87$ & $\begin{array}{l}6,0-9,5^{(1)} \\
6,0-9,0^{(2)}\end{array}$ \\
\hline $\begin{array}{l}\text { Cloro residual livre } \\
\left(\mathrm{mg} \mathrm{L}^{-1}\right)\end{array}$ & Ausente & Ausente & Ausente & Ausente & $2^{(1)}$ \\
\hline $\begin{array}{l}\text { Sólidos Totais Dissolvidos } \\
\text { (STD) }\left(\mathrm{mg} \mathrm{L}^{-1}\right)\end{array}$ & $79,4 \pm 32,61$ & $65,2 \pm 16,73$ & $73,3 \pm 31,83$ & $99,5 \pm 46,06$ & $1000^{(1)(2)}$ \\
\hline $\begin{array}{l}\text { Dureza Total } \\
\left(\mathrm{mg} \mathrm{L}^{-1} \mathrm{CaCO}_{3}\right)\end{array}$ & $122,80 \pm 96,87$ & $105,48 \pm 48,72$ & $114,16 \pm 82,82$ & $89,32 \pm 54,47$ & $500^{(1)}$ \\
\hline $\begin{array}{l}\text { Alcalinidade Total } \\
\left(\mathrm{mg} \mathrm{L}^{-1} \mathrm{CaCO}_{3}\right)\end{array}$ & $38,51 \pm 32,08$ & $22,9 \pm 16,40$ & $38,6 \pm 29,19$ & $53,44 \pm 44,30$ & ND \\
\hline Cloretos $\left(\mathrm{mg} \mathrm{L}^{-1}\right)$ & $8,39 \pm 1,43$ & $6,73 \pm 1,05$ & $6,92 \pm 0,81$ & $7,09 \pm 1,38$ & $250^{(1)(2)}$ \\
\hline
\end{tabular}

Nota: ${ }^{(1)}$ Portaria N $^{\circ} 2.914$ de 12 de dezembro de 2011 - Ministério da Saúde; ${ }^{(2)}$ Resolução CONAMA N ${ }^{\circ} 396,3$ de abril de 2008 - Água Subterrânea; ND = Não descrito na legislação; X = média; DP = desvio padrão. 
A Portaria $\mathrm{n}^{\circ}$ 2.914/2011 do MS também define que a quantidade de sólidos totais dissolvidos (STD) encontrada na água potável não deve exceder $1000 \mathrm{mg} \mathrm{L}^{-1}$. A Tabela 1 mostra os resultados para os STD, sendo que todas as amostras encontravam-se dentro do permitido para consumo humano com variação mínima de $65,2 \pm 16,73$ no período chuvoso, e máxima de 99,5 $\pm 46,06$ no período seco. Portanto, os poços analisados apresentaram valores de STD aceitáveis. Segundo Medeiros Filho (2009), os sólidos totais dissolvidos na água podem causar alterações de gosto e problema de corrosão na rede se for muito acima do valor máximo permitido.

Em relação à dureza total da água, as águas de todos os poços estudados apresentaram-se satisfatoriamente dentro do limite permitido - ficaram abaixo do VMP - conforme apresentado na Tabela 1. Este parâmetro refere-se, principalmente, à concentração de íons de cálcio e magnésio em solução, formando precipitados, sendo expressa como $500 \mathrm{mg} \mathrm{L}^{-1}$ de $\mathrm{CaCO}_{3} . \mathrm{A}$ dureza pode causar sabor desagradável à água, formação de biofilmes, efeito laxativo, e influenciar a capacidade de formar espuma por sabão e detergente. A dureza é dividida em: temporária e permanente. A dureza temporária é também conhecida por "dureza de bicarbonatos". Os bicarbonatos de cálcio e de magnésio, pela ação de substâncias alcalinas, se transformam em carbonatos, que são insolúveis. A dureza permanente deve-se à presença de sulfatos ou cloretos de cálcio ou magnésio, que reagem com as substâncias alcalinas, formando também os carbonatos (Medeiros Filho, 2009).

A alcalinidade da água é representada pela presença dos íons hidróxidos $\left(\mathrm{OH}^{-}\right)$, carbonatos $\left(\mathrm{CO}_{3}{ }^{2-}\right)$ e bicarbonatos $\left(\mathrm{HCO}_{3}{ }^{-}\right)$. Com maior frequência, a alcalinidade da água é devida a bicarbonatos produzidos pela ação do gás carbônico dissolvido na água sobre as rochas calcárias. A Portaria do $\mathrm{MS} \mathrm{n}^{\circ}$ 2.914/2011 não faz referências a esse parâmetro e não há especificações na legislação brasileira estabelecendo os limites de alcalinidade em água. A maioria das águas naturais apresentam valores de alcalinidade na faixa de 30 a $500 \mathrm{mg} \mathrm{L}^{-1} \mathrm{de}$ $\mathrm{CaCO}_{3}$. Os resultados das amostras das águas dos poços tubulares durante os períodos da pesquisa variaram de 22,9 $\pm 16,40$ (período chuvoso) a 53,44 \pm 44,30 (período seco), sendo que a alcalinidade predominante foi a de bicarbonatos (Tabela 1). Os cloretos podem estar presentes tanto em águas brutas quanto em águas tratadas, dependendo do tipo de tratamento. Concentrações altas de cloretos podem restringir o uso da água em razão do sabor salgado que conferem a mesma, e pelo efeito laxativo que podem provocar. Altas concentrações de cloreto podem significar infiltração de águas residuais e excesso de urina de pessoas e animais. Os métodos convencionais de tratamento de água não removem cloretos; a sua remoção é feita por desmineralização (deionização) ou evaporação (FUNASA, 2006). A portaria do MS n ${ }^{\circ}$ 2914/2011 estabelece o teor de $250 \mathrm{mg} \mathrm{L}^{-1}$ como o valor máximo permitido (VMP) para água potável. Os resultados encontrados nas águas dos poços tubulares não comprometem a sua qualidade, pois os valores estão abaixo do valor máximo permitido. Conforme os resultados, o período de transição seco-chuvoso apresentou maior valor médio de $8,39 \pm 1,43$, e menor no período chuvoso, 6,73 \pm 1,05 (Tabela 1). Esses dados corroboram com o descrito na literatura, que as águas subterrâneas apresentam, geralmente, teores de cloretos inferiores a $100 \mathrm{mg} \mathrm{L}^{-1}$ (Fernandes et al., 2005).

Os parâmetros microbiológicos analisados para a água de consumo humano foram os referentes às bactérias do grupo coliforme, tomando como padrão a presença ou ausência. Os indicadores avaliados foram os coliformes totais (CT), que por sua vez, são bactérias Gram negativas que podem ser encontradas no solo, e em matéria vegetal em decomposição, e não se correlacionam necessariamente com origem fecal, contudo são mais resistentes na água que as bactérias patogênicas de origem intestinal (APHA, 1998). O outro parâmetro de maior relevância trata-se dos níveis de Escherichia coli (EC), principal indicador de contaminação fecal, por ser uma bactéria presente no trato intestinal humano e em animais homeotérmicos, descrito nas legislações de vários países (Sotero-Martins et al., 2013; Felski et al., 2008; 
Cunha et al., 2012). Sendo assim os resultados dos níveis colimétricos para a água dos poços foram analisados considerando a ausência desses dois parâmetros, como especificado na Portaria No. 2.914 do MS, que é o órgão que trata da saúde. Embora a Resolução CONAMA 396/2008 seja específica para águas subterrâneas, ela é mais permissiva. Desta forma, o poço P6 apresentou valores para CT em três das quatro estações monitoradas, sendo elas: estação de transição seco-chuvosa (P-S/C), transição chuvoso-seca (P-C/S) e chuvosa (P-C). Portanto, foi o poço que apresentou mais vezes água com qualidade imprópria para consumo humano. $\mathrm{O}$ poço $\mathrm{P} 3$ esteve com água imprópria em duas estações monitoradas, sendo elas no $\mathrm{P}-\mathrm{S} / \mathrm{C}$ e P-S. Enquanto que os poços P1 e P4 somente apresentaram dados impróprios em uma estação (Figura 1). Nenhum poço na estação chuvosa apresentou níveis de coliformes detectáveis, provavelmente devido à diluição provocada pela grande quantidade de chuvas que ocorreu no período que antecedeu a coleta. Destaca-se que nos dias anteriores a coleta da amostra, a precipitação média foi de $25,1 \mathrm{~mm}$ (Figura 2), portanto este é o período sazonal de menor risco para uso da água sem tratamento. Apesar de terem sido encontrados níveis de CT nas águas em alguns períodos, não foram detectados EC em nenhuma das amostras dos poços, portanto o risco associado à presença de esgoto sanitário com contaminação recente na água dos poços foi menor. Mas foi possível detectar que houve períodos de maior risco ao consumo das águas e que as regiões onde ficam os poços P6 (área que predomina residências) e P3 (área que possui horta) são as mais vulneráveis (Figura 1), o que torna inviável a utilização dessa água para consumo humano sem que antes passe por um processo de desinfecção ou filtração, com vistas a eliminar as bactérias presentes, uma vez que a presença desses organismos pode acarretar problemas de saúde para a população que consome a água contaminada (Gonçalves et al., 2003; Archer et al., 1997).

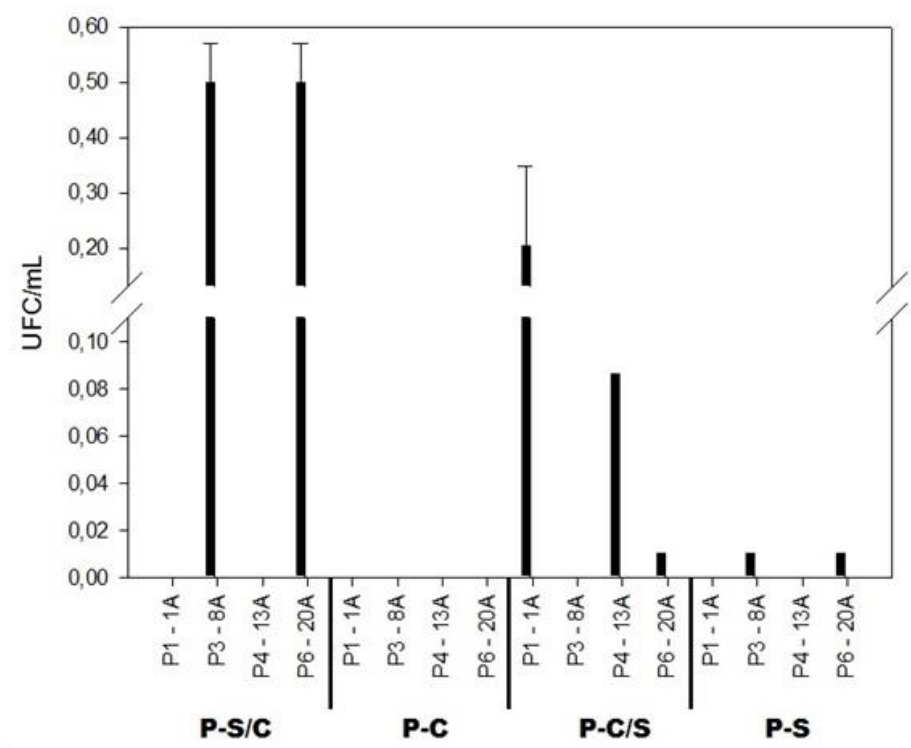

Figura 1. Níveis de coliformes encontrados na água dos poços tubulares ativos da comunidade de Cinturão Verde, nas quatro estações do ano. níveis de CT; $\square$ - níveis de EC.

Quanto às análises parasitológicas, somente foi detectada a presença de larvas de nematóide (tipo filarióide) em amostra de água do poço P4 (área predominantemente residencial) durante o período seco. De acordo com Carli (2001), essa forma infectante é capaz de penetrar na pele ou mucosas, podendo evoluir no interior do hospedeiro, ocasionando os casos de auto-infecção interna. Considerando que alguns parasitas passam 
parte do seu ciclo de desenvolvimento no solo, como no caso do Ascaris sp., a ocorrência de geohelmintos em solos contaminados por dejetos de animais constitui um problema de saúde pública, pois pode contaminar os mananciais. Devido à peculiaridade do ciclo biológico de seus agentes etiológicos, e agregado à proximidade existente entre seres humanos e animais de estimação, são considerados agentes de doenças relativamente importantes, sob a ótica epidemiológica (Rey, 2008).

Também foi feita avaliação dos sistemas existentes que compõem o saneamento rural, sendo constatada a precariedade dos serviços de saneamento básico, o que confere maior vulnerabilidade das fontes de abastecimento de água. Os motivos dessa vulnerabilidade são: a predominância de sistemas individuais inadequados da disposição final dos esgotos domésticos, dos resíduos da agricultura e domiciliares, e da criação de animais em uma proximidade inadequada em relação aos poços, e o fato das águas servidas serem lançadas a céu aberto nas ruas sem pavimentação, ocasionando infiltração, o que pode contaminar as águas subterrâneas. Os reflexos das ações de saneamento ou de sua carência são notórios sobre o meio ambiente, em particular sobre os recursos hídricos (Heller e Castro, 2007). E ainda que a comunidade seja provida de um sistema de coleta de resíduos sólidos, os mesmos são dispostos de forma inadequada podendo contribuir com percolação do lixiviado devido a decomposição da matéria orgânica e, consequentemente, uma provável contaminação do lençol freático, gerando impactos diretos na qualidade de vida e saúde humana (Santiago et al., 2001). Foi observado que alguns poços ativos possuíam dispositivo de proteção sanitária com estrutura coberta e canalização dotada de bombas submersas que recalcam água e distribuem por meio de canos, porém a canalização abastece diretamente apenas as residências próximas. $\mathrm{O}$ fator de maior agravo foi à presença de currais e chiqueiros na proximidade dos poços construídos de forma rudimentar, com risco dos dejetos dos animais estarem dispostos diretamente sobre o solo, contaminando o mesmo e provavelmente a água subterrânea.

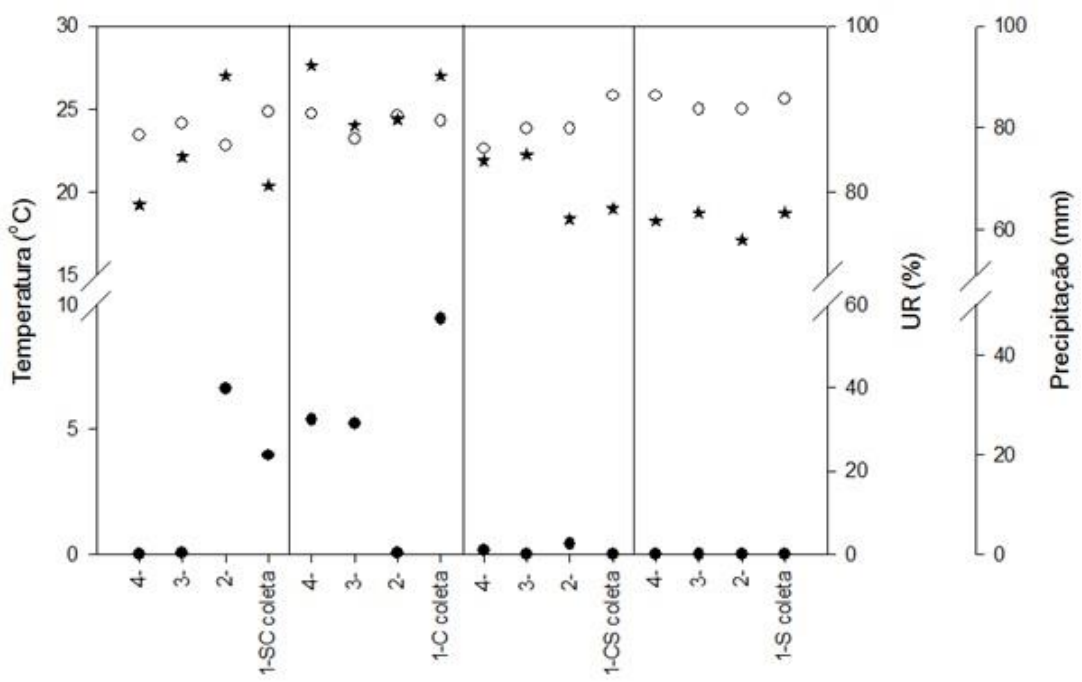

Figura 2. Dados meteorológicos relacionados com os dias de coleta.

Nota: ${ }^{\circ}$ - Temperatura do ar $\left({ }^{\circ} \mathrm{C}\right)$; $\star$-Umidade relativa do ar (\%); - Precipitação de chuva (mm). Fonte de dados históricos: INMET, 2014. SC - período de transição seco-chuvoso; C - período chuvoso; CS - período de transição chuvoso-seco; $\mathrm{S}$ - período seco. 


\section{CONCLUSÕES}

A Comunidade do Cinturão Verde não dispõe dos serviços de saneamento básico, está desprovida de meios adequados para dispor os dejetos de sistema de coleta de resíduos sólidos, e de fontes de abastecimento de água potável, que precisam ser monitoradas e tratadas, principalmente nos períodos sazonais de maior risco. Prevalece o sistema individual de disposição final de esgoto doméstico, com uso de fossas negras próximas aos mananciais. As análises físico-químicas, colimétricas e parasitológicas evidenciaram que as fontes de abastecimento de água, P6, P3, P1 e P4, estavam inadequadas, e que as águas precisam passar por controle de qualidade, pois a ausência de saneamento é um fator que concorre para a contaminação das águas subterrâneas. A contaminação das águas coloca a população consumidora exposta a diversos riscos à saúde por doenças de veiculação hídrica. $\mathrm{O}$ risco à saúde da população seria diminuído se houvesse monitoramento da qualidade das águas dos poços e tratamento nos períodos de vulnerabilidade. Tal constatação evidenciou a importância do saneamento básico, principalmente dos serviços de água e de esgotos, indispensáveis à promoção da saúde pública.

\section{AGRADECIMENTOS}

Projeto financiado pelo Conselho Nacional para o Desenvolvimento Científico e Tecnológico (CNPq), CT-Hidro n. 577.432/2008-7. Agradecemos ao Instituto Federal de Educação, Ciência e Tecnologia do Maranhão - IFMA- São Luís - Campus Maracanã pelo apoio para os processos de coleta, à Secretaria do Meio Ambiente do Estado (SEMA) por ceder o Laboratório de Microbiologia para as análises colimétricas do solo e da água, à Universidade Estadual do Maranhão (UEMA) pela colaboração nas análises físicas do solo, e ao Antônio José Jaime Maia e Adriano Moura Rocha pelo acompanhamento em etapas do projeto.

\section{REFERÊNCIAS}

AGRITEMPO. Sistema de Monitoramento Agrometeorológico Dados meteorológicos: Maranhão, estação meteorológica São Luís. 2009. Disponível em: http://www.agritempo.gov.br/agroclima/sumario?uf=MA. Acesso em: 16 abr. 2014.

AISSE, M. M.; CORAUCCI FILHO, B.; ANDRADE NETO, C. O.; JURGENSEN, D.; LAPOLLI, F. R.; MELO, H. M. S.; et al. Cloração e descloração. In: PROSAB. Desinfecção de efluentes sanitários, remoção de organismos patógenos e substâncias nocivas: aplicações para fins produtivos como agricultura, aquicultura e hidroponia. Rio de Janeiro, 2003. p. 113-168.

AMARAL, L. A.; NADER FILHO, A.; ROSSI JUNIOR, O. D.; FERREIRA, F. L. A.; BARROS, L. S. S. Água de consumo humano como fatos de risco à saúde em propriedades rurais. Revista de Saúde Pública, v. 37, p. 510-514. 2003. http://dx.doi.org/10.1590/S0034-89102003000400017

AMARAL, L. S.; DUARTE, A. N.; SILVA, V. L.; PINNA, L. C. L.; SOTERO-MARTINS, A. Parasitological indicators of contamination at sando $\mathrm{f}$ beach and monitoring by traditional methods and immunoenzymatic assay. Brazilian Journal of Biosystems Engineering, v. 9, n. 4, p. 304-311, 2015. http://dx.doi.org/10.18011/bioeng2015v9n4p304-311 
AMERICAN PUBLIC HEALTH ASSOCIATION - APHA. Standard methods for the examination of water and wastewater. Washington, 1998.

ARCHER, A.; FISCHER, E.; TURNHEIN, R.; MANOR, Y. Ecologically, friendly, wasterwater disinfection techniques. Water Research, v. 31, n.6, p. 1398-1404, 1997. http://dx.doi.org/10.1016/S0043-1354(96)00000-0

BAERMANN, G. A simple method for the detection of Ankylostomum (nematode) larvae in soil tests. Mededeel mit h Geneesk, Lab Weltvreden Feestbubdel, p. 41-47, 1917.

BRASIL. Decreto $\mathrm{n}^{\circ} 7.217$ de 21 de junho de 2010. Regulamenta a Lei ${ }^{\circ} 11.445$, de 5 de janeiro de 2007, que estabelece diretrizes nacionais para o saneamento básico, e dá outras providências. Diário Oficial [da] União, Brasília, 21 jun. 2010.

BRASIL. Ministério da Saúde. Secretaria de Vigilância em Saúde. Vigilância e controle da qualidade da água para consumo humano. Brasília, 2006.

BRASIL. Ministério da Saúde. Gabinete do Ministro. Portaria no 2914, de 12 de dezembro de 2011, que dispõe sobre os procedimentos de controle e de vigilância da qualidade da água para consumo humano e seu padrão de potabilidade. Diário Oficial [da] União, 14 dez. 2011, Seção 1, p. 39-46.

CALDEIRA, J. V. Vulnerabilidade social associada aos efeitos das mudanças climáticas na saúde pública. 2014. 150f. Dissertação (Mestrado em Saúde Pública e Meio Ambiente) - Escola Nacional de Saúde Pública, Fundação Oswaldo Cruz, Rio de Janeiro, 2014.

CARLI, G. A. Parasitos intestinais. In: CARLI, G. A. (Org.). Parasitologia clínica: seleção de métodos e técnicas de laboratório para diagnóstico das parasitoses humanas. Rio de Janeiro: Atheneu, 2001. p. 1-162.

CHAPMAN, D.; KIMSTACH, V. Selection of water quality variables. In: CHAPMAN, D. (Ed.). Water quality assessments: a guide to the use of biota, sediments and water in environmental monitoring. Cambridge: University Press, 1996. p. 59-126.

COSTA, C. C.; GUILHOTO, J. J. M. Saneamento rural no Brasil: impacto da fossa séptica biodigestor. Engenharia Sanitária e Ambiental, Ed. Especial, p. 51-60, 2014. http://dx.doi.org/10.1590/S1413-41522014019010000171

CUNHA, H. F. A.; LIMA, D. C. I.; BRITO, P. N. F.; CUNHA, A. C.; SILVEIRA JUNIOR, A. M.; BRITO, D. C. Qualidade físico-química e microbiológica de água mineral e padrões da legislação. Revista Ambiente \& Água, v. 79, n. 3, p. 155-165, 2012. http://dx.doi.org/10.4136/ambi-agua.908

CENTRO DE VIGILÂNCIA EPIDEMIOLÓGICA "PROF. ALEXANDRE VRANJAC" CVE. Divisão de Doenças de Transmissão Hídrica e Alimentar - DDTHA. Doenças relacionadas à água ou de transmissão hídrica: perguntas e repostas e dados estatísticos. 2009. Disponível em: ftp://ftp.cve.saude.sp.gov.br/doc_tec/hidrica/doc/ DTA09_pergresp.pdf. Acesso em: abr. 2014.

DANIEL, L. A. Água e doenças. In: DANIEL, L. A. (Coord.) Processos de desinfecção e desinfetantes alternativos na produção de água potável. São Carlos: PROSAB, 2001. p. $1-23$ 
FELSKI, G.; ANAISSI, F. J.; QUINÁIA, S. P. Avaliação da qualidade da água consumida pela população do município de Guarapuava, Paraná. Revista Eletrônica Lato Sensu, v. 3, n. 1, p. 1-25, 2008.

FERNANDES, M. A. B.; SANTIAGO, M. M. F.; GOMES, D. F.; MENDES FILHO, J.; FRISCKORN, H.; LIMA, J. O. G. A origem dos cloretos nas águas subterrâneas na Chapada do Apodi - Ceará. Águas Subterrâneas, v. 19, n. 1, p. 25-34, 2005.

FUNDAÇÃO NACIONAL DE SAÚDE - FUNASA (Brasil). Manual prático de análise de água. 2. ed., rev. Brasília, 2006.

GONÇALVES, R. F.; JORDÃO, E. P.; SOBRINHO, P. A. Introdução. In: PROSAB. Desinfecção de efluentes sanitários, remoção de organismos patogênicos e substancias nocivas: aplicações para fins produtivos como agricultura, aquicultura e hidroponica. Rio de Janeiro, 2003. p. 1-26.

GRONEWOLD, A. D.; WOLPERT, R. L. Modeling the relationship between most probable number (MNP) and colony-forming unit (CFU) estimates of fecal coliform

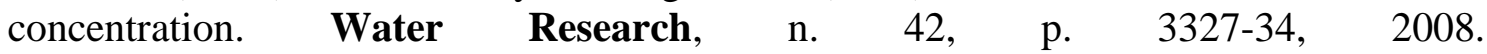
http://dx.doi.org/10.1016/j.watres.2008.04.011

HAGER, F. P. V. Águas subterrâneas no direito público. 2007. 15f. Monografia (Especialização em Direito Público) - Faculdade Metropolitana de Belo Horizonte, Belo Horizonte, 2007.

HANDAM, N. B. Condições sanitárias da água residencial, do solo peridomiciliar e dos rios das comunidades do território de Manguinhos, RJ. 2016. Dissertação (Mestrado em Saúde Pública e Meio Ambiente) - Escola Nacional de Saúde Pública, Fundação Oswaldo Cruz, Rio de Janeiro, 2016.

HELlER, L.; PÁDUA, V. L. (Orgs.). Abastecimento de água para consumo humano. 2. ed. Belo Horizonte: Ed. UFMG, 2006. 428 p.

HELlER, L.; CASTRO, J. E. Política pública de saneamento: apontamentos teóricoconceituais. Engenharia Sanitária e Ambiental, v. 12, n. 3, p. 284-295, 2007.

HERRÁIZ, A. S. La importancia de las aguas subterráneas. La Revista de la Real Academia de Ciencias Exactas, Físicas y Naturales, v. 103, n. 1, p. 97-114, 2009.

LUTZ, A. O Schistosoma mansoni e a schistosomatose segundo observações feitas no Brasil. Memórias do Instituto Oswaldo Cruz, v. 11, p. 121-155, 1919.

MEDEIROS FILHO, C. F. Noções sobre tratamento de água. In: Abastecimento de água. 2009. Disponível em: http://www.dec.ufcg.edu.br/saneamento/Agua.html. Acesso em: dez 2016.

PINTO, C. M. A.; ARAUJO, N. A.; SILVA JÚNIOR, D. F. Diagnóstico preliminar do saneamento rural na comunidade de Engenho Velho no Município de João Pessoa/PB. Revista Ambiental, v. 1, n. 1, p. 26-36, 2015.

REY, L. Parasitologia. 4. ed. Rio de Janeiro: Guanabara Koogan, 2008. p. 1-25.

RICHARDS, L. A. (Ed.). Diagnosis and improvement of saline and alkali soils. Washington: U.S. Government Printing Office, 1954. 
SANTIAGO, M. F.; FRISCHKORN, H.; SALES NETO, P.; MENDES FILHO, J. The recharge mechanisms in an alluvial aquifer zone in northeast Brazil. Ground Water, n. 39, v. 1, p. 18 - 23, 2001. http://dx.doi.org/10.1111/j.1745-6584.2001.tb00347.x

SOTERO-MARTINS, A.; DUARTE, A. N.; CARVAJAL, E.; SARQUIS, M. I. M.; FERNANDES, O. C. Controle da qualidade microbiológica e parasitária em áreas de recreação. Gestão \& Saúde, v. 4, n. 3, p. 1075-1092, 2013. http://www.arca.fiocruz.br/handle/icict/10709

TCHOBANOGLOUS, G.; BURTON, F. L.; STENSEL, H. D. Wasterwater treatment. In: Wastewater engineering: treatment and reuse. Boston: Metcalf \& Eddy Inc., 2003. p. 10-20.

VON SPERLING, M.; JORDÃO, E. P.; KATO, M. T.; SOBRINHO, P. A.; BASTOS, R. K. X.; PIVELLI, R. Lagoas de estabilização. In: PROSAB. Desinfecção de efluentes patógenos e substâncias nocivas: aplicações para fins produtivos como agricultura, aquicultura e hidroponia. Rio de Janeiro, 2003. p. 276-336. 